\title{
GEORGE WASHINGTON GRAYSON AND \\ THE CREEK NATION,
}

$1843-1920$

By

MARY JANE WARDE

Bachelor of Arts

University of Tennessee

Martin, Tennessee

1966

Master of Arts

Oklahoma state University

Stillwater, Oklahoma

1981

\author{
Submitted to the Faculty of the \\ Graduate College of the \\ oklahoma state University \\ in partial fulfillment of \\ the requirements for \\ the Degree of \\ DOCTOR OF PHILOSOPHY \\ May, 1991
}


Thesis

1991D

W265g

cop. 2 
C O P Y R I G H

MARY JANE WARDE

1991 


\section{GEORGE WASHINGTON GRAYSON AND}

THE CREEK NATION,

$1843-1920$

Thesis Approved:

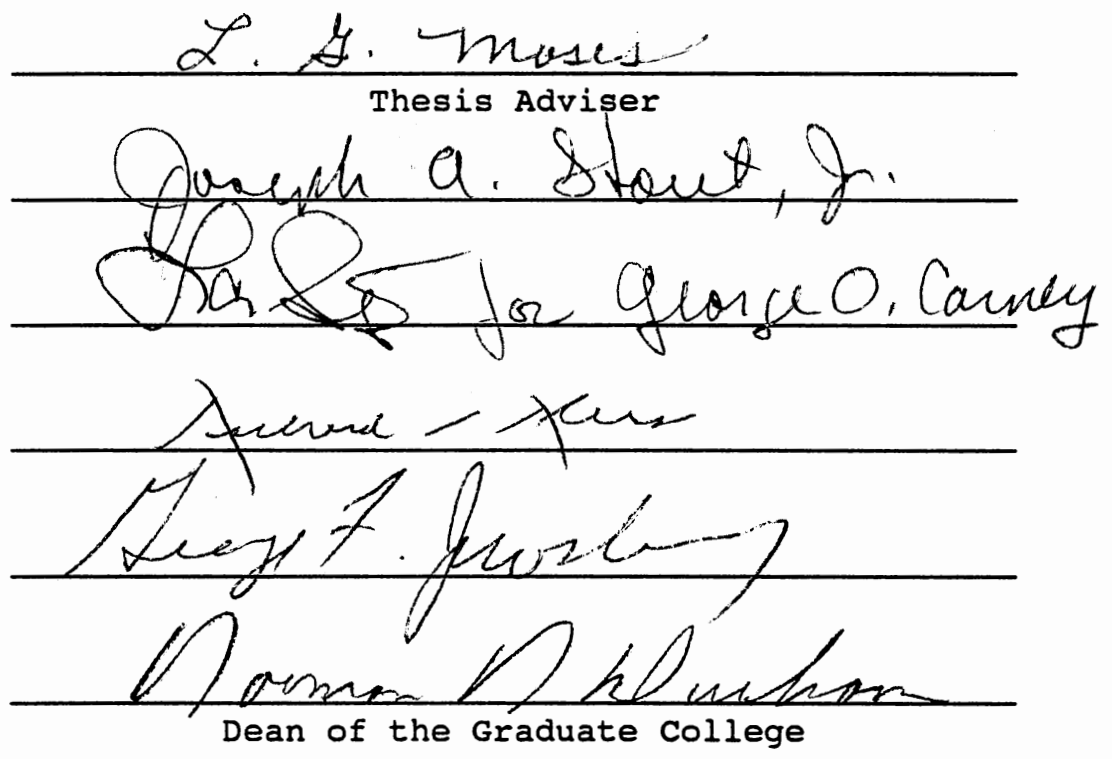


PREFACE

George Washington Grayson is a rare historical figure in that he was a well-educated, articulate, and sophisticated Indian. He left us a wealth of documents through which to see his world as he saw it. He participated in almost every event affecting the Creek Nation during critical periods of its existence: the aftermath of the traumatic Removal, the Civil War, Reconstruction, the economic development of the Indian Territory, the dissolution of the Five Civilized Tribes, and the early statehood period of Oklahoma. As a perpetual member of the Creek national government and its representative to the Federal Government, he understood the unequal relationship between the two. He did all he could through both his private and public life to defend Creek selfgovernment and the Creek landbase.

Grayson was one of many mixed-blood Creeks, several as welleducated and as politically astute as he. Iike them, he bridged the two cultures. Living very much in the white style as a businessman and newspaper publisher, he still saw himself and them as Creek. The study of his life provides insight into the place of the mixed-blood in Creek society. It offers in this special case an answer to the difficult question, "Who is an Indian?"

Because Grayson's life was inseparably intertwined with that of the Creek people for nearly eight decades, a study of it necessitates taking a fresh look at Creek history. Grayson was a product not only of his 
times but also of the Creek past. Because Grayson's political career extended several years beyond the formal dissolution of the nation on March 4, 1906, this study covers ground not previously explored in the major works on the Creeks and the Five Civilized Tribes. The last major tribal history of the Creeks was Angie Debo's The Road to Disappearance, published in 1941.

Grayson probably considered his life in many ways a failure, because most of his battles, public and private, ended eventually in defeat. Except for a few old-timers, local historians, and descendants, he has been forgotten in Eufaula, Oklahoma, and at the office of the Indian Journal, the town and the newspaper he helped found.

But Grayson lived a very full public and private life; his name is omnipresent in the Creek National Records and in Federal records relating to Creeks. He was a prolific writer as well. So much documentation related to, let alone by, an Indian is rare. Even more rare are the forty-four volumes of daily journals Grayson left; they cover the critical period in Creek affairs from 1898 to 1917 . I had the opportunity to study them briefly and found them extraordinary in their content and perspective. Unfortunately, even though portions of them have been published previously, Grayson's heirs are currently reluctant to have outsiders read them. In accordance with their wishes, I have refrained from using any except previously quoted excerpts.

When working with this type of topic, the historian encounters certain difficulties. One is the lack of newspapers in the pre-Civil War Indian Territory from which to infer public opinion. While a number of Indian-owned and published newspapers existed in the three decades 
after the war, by the end of the century this indicator of Indian public opinion had nearly vanished. Only the white point of view on many current events is available. Census data is also rare and sketchy for the period up until the Dawes rolls were compiled near the end of the nineteenth century. The Creeks kept voluminous government records, but they did not record debates and votes on bills in their council. Party platforms are unusual, and existing election returns are incomplete. Most Creek records up to March 4, 1906 were given into the safekeeping of the Oklahoma Historical Society and are available to the researcher. But Creek records dealing with the vestigial government kept in place after March 4, 1906 are unavailable.

other problems include terminology and spelling. I have chosen to use "Indian" rather than the current "Native American" because it is the term Grayson used when he spoke of himself and those of his race. He referred to himself as both a "Muskogee" and a "Creek"; I have used these interchangeably. I have generally called Grayson's second language "Muskogee" as he did, although he sometimes spoke of it as "Creek" or "the Indian." The original name of his Scots ancestor was Grierson. By the period of the Removal, the name had been modified to Grayson, and I have so called family members as they made that transition to the Indian Territory.

The Muskogee language is complex and strange to ears accustomed to English. At the same time, Creeks had difficulty with English names, so that Kennard might also be spelled Canard and Kennaird. Where necessary I have placed an alternate spelling or shortened form of the name in parentheses. Writers have not adopted one system for spelling Muskogee 
words, so that a noun such as tustunuggee may be spelled a variety of ways. For people and place names I have used the most familiar spellings, following the example of Angie Debo or of recent maps.

The study of Grayson's life has been a rewarding experience. It suggests that there is much more to be said about mixed-blood Indians, particularly those of the Five Civilized Tribes. The point that comes most clearly across from Grayson's experiences is that his degree of acculturation had less to do with his sense of personal identity than the society in which he lived, his own perceptions, and the way other Creeks perceived him.

It is rare that a historian finds so rich a subject as George Washington Grayson, and I am truly thankful to have had the priviledge of researching his life. Dr. W. David Baird introduced me to him in the first semester of my graduate work. Even after Dr. Baird took a position at Pepperdine University, he continued as my dissertation adviser. He oversaw my research and the writing of most of this biography. Because he accepted a Fullbright Scholarship in New Zealand, I was unable to finish the work under his direction. Dr. I. G. Moses graciously stepped in to see me through the last stages; I value his scholarship, his sensitivity, and his moral support. In Dr. Baird's absence, Dr. Richard Rohrs went beyond the usual duties of a committee member to critique each chapter as I wrote it. Dr. George Carney was originally on my committee; because he was unable to continue, Dr. Louis Seig consented to take his place as the outside member. Dr. Joseph A. Stout and Dr. George Jewsbury have also contributed their time and their scholarly perspectives to this project. I would also like to thank Dr. 
LeRoy Fischer for his professional generosity and for helping me understand Grayson's Civil War experiences.

A number of people helped make my research enjoyable and rewarding. David Grayson (Tod) Hansard and Colonel Harold o. Hoppe, a grandson of Sam Grayson, were particularly helpful. Mrs. Mildred Fuller Ewens of Eufaula, Oklahoma, "Little Sunny Millie Mitowoli" to her Grandfather Grayson, turned him into a flesh-and-blood person for me. My main. regret is that Mrs. Ewens died at Christmas 1990, and so did not live long enough to see how much she helped me understand Chief Grayson. Mrs. Dorothy Follansbee opened her historic Eufaula home to me; she, Mrs. Lela Whitaker, and Mrs. Kittye McIntosh Stafford took me back to the Eufaula of an earlier day. Mr. James Carey shared with me the enthusiasm and fruits of his own research into McIntosh County history. Reseaching at the Western History Collection at the University of Oklahoma and at the Oklahoma Historical Society is always a pleasure. I especially appreciate the suggestions of archivist William Welge. At Edmon Low Library at Oklahoma State University, I owe much to John Phillips and the Government Documents staff and to Mary Helen Evans in the Non-Book Room. A. Raymond Estep Fellowship and a Townsend Dissertation Fellowship helped finance my research. Susan oliver of the History Department helped me cope with a new word processing system. John $R$. Deluca of the Geography Department created original maps of the Creek Nation to illustrate the text.

Only my family knows how much patience they have had to exert to bear with me through this project. My parents, Frances and Buster Williams of Martin, Tennessee answered when called on; my sister, Linda 
Waymon, helped me find the United States Personnel Management office in the wilds of south St. Louis. To my sons, Colin and Chris, I give special thanks for getting along without me for a while. No one helped more than my husband Bill, who took up the slack at home and always told me I could do it. Thank you. 
TABLE OF CONTENTS

Chapter

Page

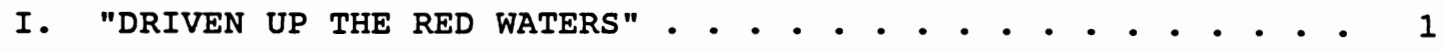
Notes . . . . . . . . . . . . . . . . 25

II. "THE RISING GENERATION OF THE CREEKS" • • • • • • • • • $\quad 31$ Notes . . . . . . . . . . . . . . . . . 60

III. "THE SPIRIT OF OUR FATHERS" • • • • • • • • • • • • • • • . 70 Notes • • • • • • • • • • • • • • • • • • • 111

IV. "INDIAN CAPITAL AND INDIAN BRAINS" • • • • • • • • • • . . . 122 Notes . . . . . . . . . . . . . . . . . 154

V. "ALL THAT IS LEFT FOR OUR CHILDREN" • • • • • • • • • • • • 162 Notes • . . . . . . . . . . . . . . . . . 194

VI. "SAVE WHAT WE MAY OUT OF THE APPROACHING WRECK" • • • • • • 207 Notes . . . . . . . . . . . . . . . . . . . 244

VII. "FALLEN TO THE MERCY OF OTHER POWER" . . . . . . . . . . . . 257 Notes . . . . . . . . . . . . . . . . . . 303

VIII. "NEVERTHELESS, INTENSELY INDIAN" • • • • • • • • • • • • • • 318

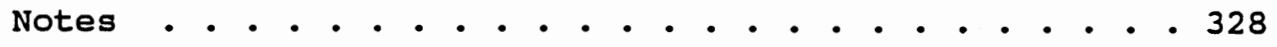
BIBLIOGRAPHY • • • • • • • • • • • • • • • • • • • • • • • • • 329 


\section{LIST OF FIGURES}

Figure

Page

1. The Creek Nation during the Creek War of 1813-1814 . . . . . . 4

2. The Creek Nation about 1856 . . . . . . . . . . . 21

3. Civil War Battle Sites in the Indian Territory . . . . . . 91

4. The Creek Nation about 1880 . . . . . . . . . . 130

5. The Post-Civil War Creek Nation and the Unassigned Lands . . 166 


\section{LIST OF ABBREVIATIONS}

For the convenience of the reader, the following is a list of abbreviations used in the notes for each chapter.

AR CIA

$A R$ DI

CCF

CHN

CRN

FCT

ITD

NA

OHS

OIA

US

WHC
Annual Reports of the Commissioners of Indian Affairs Annual Reports of the Department of the Interior Central Classified File Cherokee National Records

Creek National Records

Five Civilized Tribes Files

Indian Territory Division

National Archives

Oklahoma Historical Society

Office of Indian Affairs

United States

Western History Collection 
CHAPTER I

"DRIVEN UP THE RED WATERS"

To be born a Creek in 1843 was to be born to a heritage of pride and bitterness, resilience and adaptability. This was the heritage passed to George Washington Grayson, "a Muscogee Indian by blood," as he described himself, "born and reared in their midst,"1 in the Creek Nation in the Indian Territory in that year.

Grayson's accomplishments, lifestyle, and appearance tempt one to forget that this mixed-blood was at most half-Creek. A photograph of him taken in 1908 and filed with the Bureau of American Ethnology at the Smithsonian Institution shows an elderly man with a pale complexion pitted from smallpox, a full white beard, stern dark eyes, and stylish dress. A penciled notation on the back of the photograph states, "Shows no trace of Indian blood"2--as if Grayson were making the type of fraudulent claim so common in those days of the allotment process. The writer clearly saw only the sophisticated, urbane Grayson, to all appearances a white man. Yet this businessman, diplomat, and scholar dedicated much of his adult life to the service of the Creek Nation. Indeed, much of what he did and wrote in his seventy-eight years only makes sense if one remembers that he thought of himself as creek rather than white, with a secure place in the creek social, economic, and political structure. 
In this perception Grayson did not fit the stereotype of the mixed-blood uncomfortably poised between two worlds, completely at home in neither. He knew who he was: he was a Creek and an Indian. From 1843 until his death in 1920, when he was Principal Chief, his life and that of the Creek Nation were inseparably intertwined. What accounted for that firm sense of Creek identity in a man so outwardly un-Indian? The answer for Grayson lay in several centuries of Creek acceptance of foreigners, in their dynamic culture, in his own ingrained distrust of whites, and in a set of fortunate circumstances that provided him valuable skilis at the time the Creek Nation needed them most. Thus, while acknowledging his scots ancestry and taking pride in his own successful negotiation of a white-dominated world, Grayson in his own .1d remained firmly Creek. Moreover, he spent his last days striving to preserve the Creek identity, language, and heritage.

In the early 1900s Grayson began writing a history of the Creeks from their perspective to demonstrate, he said,

a true and sympathetic interest in a people who, prior to their contamination resulting from association with other races and people, were the true embodiment in its pristine beauty and purity of all that is embraced in the terms patriotism, bravery, integrity and many of the other virtues approved of in other peoples by our present Christian civilization. 3

In his research he made an effort to locate the old people of his nation to record their knowledge; but, he wrote sadly, it was already too late. Most of those who knew the Creek side of history were already gone. Still he recorded the facts and traditions he knew until ill-health forced him to put the work aside. What he could not do himself, he facilitated for others. He opened his home and his knowledge of his 
people to the Smithsonian's anthropologists to allow them to preserve the language, lore, and customs of his remarkable nation. ${ }^{4}$

Their composite research presented a people, who, as was common among Native Americans, perceived themselves as unique. This included in pre-Columbian times even the Creeks' close neighbors to the west, the Choctaws and Chickasaws, who spoke a Muskogee dialect, and the Seminoles, an off-shoot of the nation. From one generation to the next, the Creeks--or as they called themselves, the Muskogees--passed on the tradition of their origin far to the west. Stripped of its mythic embroidery, the tradition told how they had come eastward from a mountain range, crossing the Mississippi River to settle in the southeastern United States. They made their home in today's Georgia and Alabama, ranging at times into Tennessee, South Carolina, and Florida. What set the Creeks apart among the Southeastern tribes was their political organization, which some anthropologists have described as the most advanced in any tribe north of Mexico, with the possible exception of the Iroquois Confederacy. 5

Unlike the Iroquois, who were a cooperative grouping of related tribes, the Creeks based their political structure on a system of towns. (See Figure 1.) Four towns constituted the early nucleus of the Creek Confederacy. These towns were Cusseta, Coweta (Grayson's own town), Arbeka, and Tuckabatchee. Over time other tribes and remnants of tribes gravitated into the Muskogee orbit, gained recognition as "towns," and were adopted into the loose confederation. Thus Muskogee-speakers such as the Koasatas, Hichitas, Alabamas, and Tuskegees joined as well as non-Muskogee-speakers, among them the Shawnees, Natchez, Catawbas, and 
Figure 1. The Creek Nation during the Creek war of $1813-1814^{6}$ 


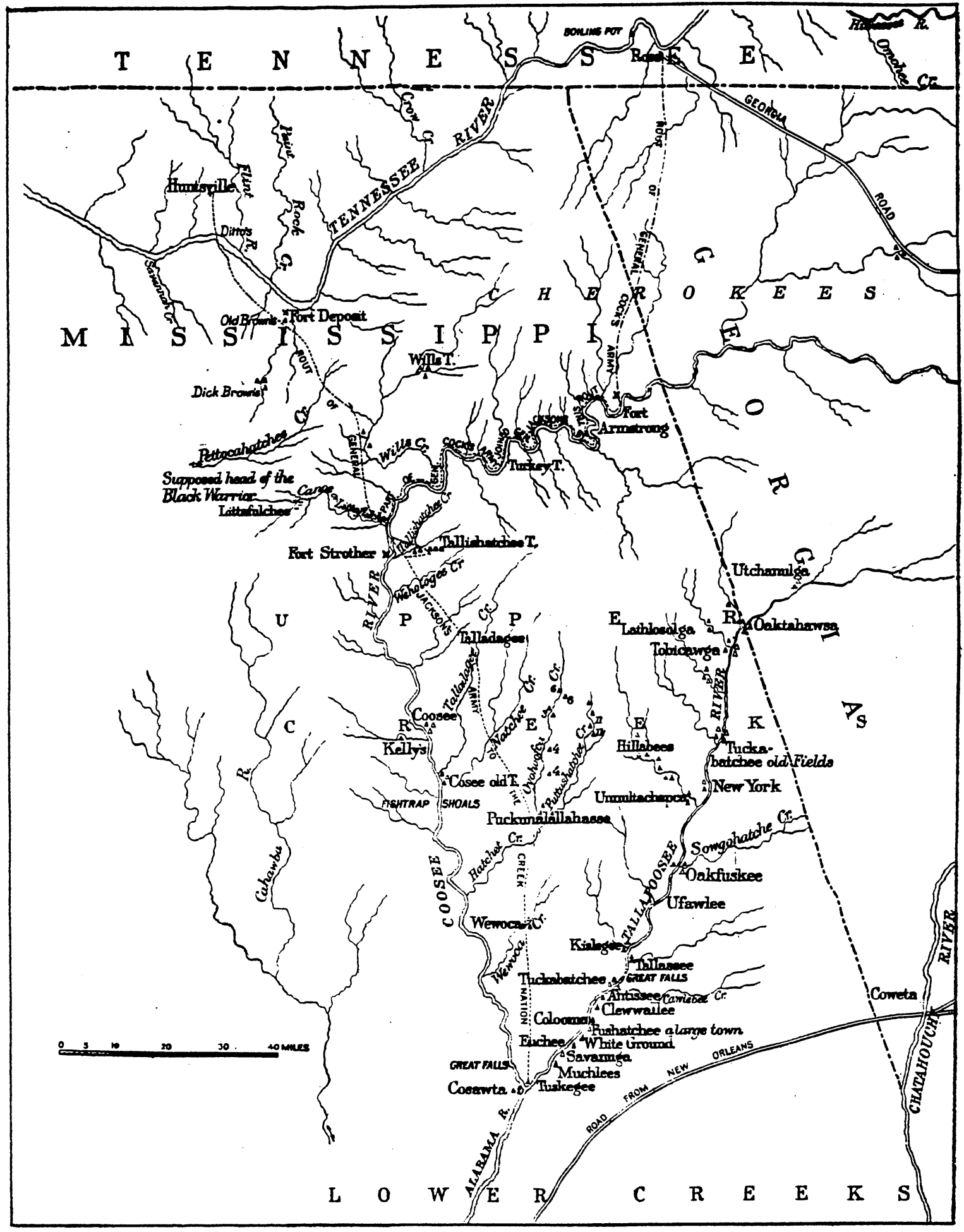


Euchees. The confederacy offered refuge and security to tribes decimated by enemies or disease. This traditional tendency toward tribal adoption also gave the Creeks an international outlook that was unusual among Native Americans. 7

The concept of a "town" was complex enough to warrant two Muskogee words: talofa denoted the geographical location of a village or cluster of associated villages while tulwa implied the more important internal political and ceremonial organization of those villages. The number of towns varied as peoples joined and left the confederacy and as large "mother" towns sub-divided. By 1790 there were about fifty Creek towns; throughout most of Grayson's life they numbered forty or more. Heredity and tradition tied the members of a tulwa such as Coweta together; and membership descended matrilineally. Each town had its own sense of identity and a considerable degree of autonomy. Even though town members sometimes lived in a cluster of small villages, all recognized the single square ground with its contiguous public structures as the focal point of their town. Here the ceremonial town fire burned; custodians kept sacred objects belonging to the town; and members carried out social, religious, and political activities. 8

At this square ground each morning the town king or micco met with his council of advisors and warriors. After grave and polite discussion they allotted communal lands according to need, rendered judgments in disputes, and discussed matters of mutual concern, local or national. The miccos used a speaker or interpreter (yatika) to introduce important topics to the council and to deliver their decisions to the people. Creeks valued these speakers highly for their skill and knowledge. A 
hothlibonaya ("war speaker") traveled with the micco on diplomatic missions, defended the interests of the people before foreigners, and conducted the actual negotiations. It was as a yatika or hothlibonaya--an office updated and renamed "delegate"--that George Washington Grayson most often served the Creeks for more than five decades. Each town was either a red town with associated war duties (as was the case with Coweta) or a white town with peace duties. The prominence of the town and its leaders rose and fell according to whether the confederacy was at peace or war. 9

Besides town membership, each Creek had, in common with most Native Americans, membership in a clan, also a matrilineal inheritance. Clans existed across town lines so that a Tiger clan member such as Grayson expected to find fellow clan members in other towns within the confederacy. Though clan membership was less important than town membership, it dictated whom a person might marry, the degree of formality of his relationships with others, even those with whom he might tease and banter. It insured a secondary source of support and aid beyond the family circle. Clans also carried degrees of prestige. The highest was the Wind Clan, which often supplied the leadership in a Creek town; but the Tiger clan also ranked high. Though the importance of the clans declined somewhat after removal to the Indian Territory, they continued to exist, especially among the traditionalists. Grayson believed that as late as his own childhood in the 1840 s clan membership was often more important than consanguinity. He himself was quite conscious of the obligations clan membership demanded and the relationships it supported. 10 
Some historians suggest that ultimate leadership over the confederacy and, indeed, the confederacy itself were creations of the Europeans who began an extensive contact with the Muskogees in the seventeenth century. Before that time national councils of town chiefs and advisors met periodically, and the chiefs of Tuckabatchee and Coweta enjoyed recognition as the principal chiefs. But when the intercolonial rivalry of Spain, France, and England encroached on the Muskogees, Europeans encouraged the concept of a unified political structure and helped elevate a particular chief with whom they preferred to deal to "king" of the Muskogees. 11

During the eighteenth century English traders working out of the colony of South Carolina further affected the Muskogee political organization by identifying two groups within the confederacy. Because the Muskogees generally lived along water courses, the English began to call them "Creeks." Those who lived along the lower reaches of the Chattahoochee and Appalachicola rivers in today's southern Alabama and northern Florida recognized Coweta as their principal red town and Cusseta as their principal white town. The English designated them Lower Creeks and noted that they were usually more approachable both geographically and commercially. Over time these Creeks adapted easily to aspects of white culture. But the greater number of Creeks lived to the north on the headwaters of the Alabama River. They looked to Tuckabatchee as their main red town, and they regarded Arbeka as their peace town. The English called these the Upper Creeks and considered them less approachable and less receptive to English influences. But the Upper Creeks insisted on equality of recognition with the Lower 
Creeks in English-Creek negotiations; consequently, the Creek confederacy took on a dual character diplomatically. 12

Similarly, as the intrigues and violence of the intercolonial wars affected the confederacy, the leaders of the red towns gained and kept ascendancy over the white towns. Increasingly, then, this external recognition of one or two supreme chiefs and of a "confederacy" hierarchy that could speak for all the Creeks became a convenience and a useful tool in Creek-European diplomacy and trade. ${ }^{13}$

Many anthropologists and ethnohistorians have written of the devastating impact the European contacts had on the Creeks. The demand for objects of European manufacture transformed the Creeks from a sedentary hunter-farmer culture into a nation of commercial hunters. The menfolk ranged further from Creek lands to find furs and skins with which to purchase desirable trade items. More of the heavy work of farming fell to the womenfolk, who always before did the lighter gardening. Slaving expeditions caused frequent conflicts with neighboring tribes. Items of European manufacture replaced those produced domestically, causing the abandonment of ancient skills and crafts. Alcoholism increased; and, most importantly, a series of epidemics--common to the Europeans but previously unknown to Native Americans--struck the vulnerable southeastern Indians with severe consequences. A Creek population extrapolated at two hundred thousand before the Europeans arrived on the continent declined to about twenty thousand by the time the Europeans came among them. 14

All this terribly and undeniably disrupted Creek life. But at least one other ethnohistorian has pointed out that Englishmen, at least 
those who settled Virginia in the early seventeenth century, had much in common with such peoples as the Creeks: village life, a primitive level of farming, folk medicines, superstitions, weapons of war, and a love of hunting. These commonalities made the two cultures, in spite of English insistence on the superiority of their Christian civilization, not entirely incompatible. A number of English folk "settled with the savages," 15 and this defection was extensive enough to concern the English authorities. The Creeks never maintained a static culture or a xenophobic outlook as their expandable confederacy demonstrated. That they readily adapted aspects of European culture speaks strongly of Creek flexibility, of the dynamic nature of Creek society, and of cultural compatibilities that worked in both directions.

At the same time, the more frequent contacts with Europeans, particularly the English and Scottish traders among the Lower Creeks created within Creek society a new element, the mixed-blood. By the early nineteenth century, family names such as McGillivray, McIntosh, Perryman, Carr, Barnett (Barnard), Kennard (Canard), and Grierson (Grayson) appeared among them. South Carolina traders found it both convenient and profitable to marry Creek wives to ally themselves with Creek towns. Their mixed-blood sons, often with some degree of education and an understanding of the English language and culture, remained in their natal towns, accepted as town and clan members in that matrilineal society, acting as brokers in commerce and diplomacy. They ran the town trading posts, catering to a people ever more dependent on white-manufactured goods. Less acculturated Creek chiefs looked to them for interpretation and advice. In the late 1700s Alexander McGillivray, 
half-blood son of trader Lochlan MCGillivray and a member of the Wind clan, rose to prominence among the Lower Creeks. Similarly mixed-bloods William Weatherford and William McIntosh became men to reckon with in the early 1800 s. $^{16}$

Unlike the mixed-bloods (whom some historians call the metis) of the Great Lakes region, these Creek mixed-bloods did not become a separate people from their maternal and paternal relatives. Full-blood Creeks did not force them into a political or social self-consciousness as outsiders because Creeks habitually accepted foreigners and assigned them a pláce in the confederacy. While increasing racism among the English made mixed-bloods less than welcome in the Georgia and South Carolina settlements, they continued to occupy a secure place in the Creek social structure. Indeed, these mixed-bloods became the dominant force in Creek politics through historical events and their recognized ability to deal with the whites. 17

Nor were the mixed-bloods, in spite of their primary occupation as skin brokers and traders, so bound to the trade for a livelihood as were their Great Lakes counterparts. Although it was true that Creeks and other southeastern Indians became reliant on European trade goods and turned to commercial hunting to finance their purchases, they lived in a region benevolent toward agriculture. Creeks had been sedentary farmers with a communal land use system for centuries. They never completely abandoned those agricultural traditions. Rather, under the influence and tutelage of Southern Indian Agent Benjamin Hawkins for two decades beginning in 1796, they turned to livestock raising, cotton production, and the plantation system with attendant African slave labor. The 
result was that Creek full-bloods and mixed-bloods expanded traditional agricultural pursuits and adapted them to the example of neighboring whites. Thus, Alexander McGillivray, mixed-blood son of a Scots trader, bequeathed at his death in 1793 an estate that included sixty slaves, three hundred cattle, and numerous horses. William McIntosh was also a plantation and slave owner as well as a rising political star of Coweta Town and the Lower Creeks by 1810.18

George Washington Grayson's most prominent white ancestor, though he arrived in the Creek country somewhat later than the first McGillivray and McIntosh, followed much the same route to assimilation into the Creek nation. Robert Grierson, a Scot, immigrated into the colony of Georgia with his brothers James, Thomas, and William some time before the Revolutionary War. Thomas settled among the Lower Creeks of Eufaula Town, married, sired a mixed-blood son, and farmed five hundred acres on Little River near the land of his brother James. A militiaman supporting the rebellious colonies, he died about 1775. James Grierson, was a colonel of militia and a Loyalist of infamous reputation during the Revolution. Robert Grierson settled among the Upper Creeks of Hillabee Town and married Sinnugee, a woman of the spanalgee clan. Their children in 1796 were Sandy (Alexander), Sarah (married to Stephen Hawkins, a full-blood), Walter, David, Eliza, and William. Their last-born, Katy, was the grandmother of George Washington Grayson. Creeks and their slaves, troubled by the unfamiliar consonants and vowels of the Grierson name, modified it to Grayson within a generation or two. 19

In 1796 newly appointed Indian Agent Benjamin Hawkins arrived in the Creek country to take up his duties. Although Hawkins judged most 
of the whites who intermarried with the Creeks fairly worthless, he respected Robert Grierson. At the time of his first visit with the Grierson family, Robert had moved beyond trading and was farming thirty acres and producing a variety of foodstuffs. He was also beginning to raise cotton and had hired a woman to teach his womenfolk how to spin and weave the two thousand pounds he produced annually. He owned three hundred cattle and thirty horses as well as the slaves to care for them and his cotton fields. Although Grierson was a former Loyalist colonel, he impressed Hawkins as a reliable man and good citizen of the Creek country. Hawkins frequently visited the well-run Grierson home and often turned to Robert Grierson for information and help with his official duties. With more men like him, Hawkins believed, his task of ulturating the Creeks for ultimate assimilation into white civilization would be easier. 20

But the Red Stick War of 1813-1814 disrupted Robert Grierson's pleasant and productive life in the Creek country. This disturbance was a facet of Tecumseh's attempt to create a new confederacy of all the tribes confronting the American frontier from the Great Lakes to the Gulf Coast. This Shawnee chief, half Creek himself, came to the relatively powerful tribes of the southeastern United States on a recruiting mission on behalf of his confederacy; he also brought the unifying message of traditionalism and renewal of his brother The shawnee Prophet. But he found that most of the southeastern Indians had little in common with his followers in the old Northwest. In their strength they felt less threatened by the advancing whites. Already they were too acculturated and well on the way to qualifying for their title, the 
"Five Civilized Tribes." 21

Only among the more traditional Upper Creeks did Tecumseh make some converts, a faction known as the "Red sticks." Factionalism between the Red Sticks and the more acculturated Lower Creeks escalated into a Creek civil war that spilled over onto neighboring white settlers, most notably in the Fort Mims Massacre of August 30,1813 . News of the massacre electrified the settlements of Tennessee and surrounding states. Large forces of Federal troops and militia converged on the Creek country in a campaign that transformed Andrew Jackson of Tennessee into a national hero. Lower Creeks led by William McIntosh and Timpoochee Barnard regarded the Red Sticks as rebels and enemies; as a consequence, McIntosh and his Creek adherents willingly joined Federal iorces and contingents of Cherokees and Choctaws in putting down the Red stick rebellion. In 1813 and 1814 these troops swept through the Creek country destroying Red Stick villages and driving fleeing tribesmen toward a last stand at Horseshoe Bend on the Tallapoosa River. But their coming was too late to protect the Grierson family. 22

When the Red Sticks began performing The Shawnee Prophet's dance, they declared they meant to destroy everything creeks had received from the Americans and to put to death everyone who would not join them. Red Stick fanatics targeted the Grierson family, at home among the scattered villages of Hillabee Town. Not only were they more acculturated than their neighbors, Eliza Grierson was a wife of Chief William McIntosh. 23 Robert Grierson, according to a letter of August 1813, "had all his negros (73) and every eatable thing taken from him."24 His daughter-inlaw, a widely esteemed woman, visiting ocmulgee Town to teach the women 
there how to spin and weave, was stripped to her shift and robbed of her cattle and hogs. Two months later the Hillabees sent the elderly Grierson to General Jackson with offers of peace. In spite of the general's immediate acceptance, another force of white troops destroyed the Hillabee villages, probably in reprisal for the Fort Mims Massacre. They killed sixty warriors and took 250 prisoners. The survivors fled to the Red Sticks. All retreated to Artussee Town and took refuge in the fortified and provisioned Horseshoe Bend of the Tallapoosa River, expecting supernatural intervention on their behalf. 25

But on March 27, 1814 Jackson's army overwhelmed the log breastworks and killed at least 557 of its defenders. Some seventy survivors, most of them wounded, escaped the slaughter to join their women and children, hidden in a swamp downstream. Among them were two brothers, Emathla Hutke and Tulwa Tustunuggee from Hillabee Town. They were the mixed-blood sons of Intakfahpky, a full-blood medicine man, and Mary Benson, a Scots-Irish captive adopted and reared by the Creeks. Wounded nine times in the battle, Tulwa Tustunuggee survived because his brother carried him off the battleground in the darkness and hid him in the swamp. He recovered but the bullets were never removed, causing him recurring bouts of pain for the rest of his life. Some time later he married Katy Grierson and drifted into the well-to-do mixed-blood orbit. But he never forgot Horseshoe Bend. 26

Andrew Jackson's victory broke the back of Red stick resistance, but it brought little good to the Creeks. Even though William McIntosh and the Lower Creeks fought as allies in Jackson's expeditionary force, the Treaty of Fort Jackson of 1814 penalized all Creek people for the 
Red Sticks' apostasy. The Creeks ceded twenty-two million acres of land to the United States and made other major concessions. The Creeks withdrew to the remainder of their homeland in Alabama. Federal agents estimated that friendly Creeks suffered property losses of $\$ 195,417.90$; Congress did not make the final payment on their claims until 1853. The Griersons were among those who lost property, but their claims--particularly for slaves lost during the rebellion--were still in litigation years later. 27

Nor were the Creeks left in peace in their remaining territory. The arguments for the removal of all the eastern tribes to a reservation beyond the Mississippi River gathered force during the next two decades. Creeks no more than any of the other Five Civilized Tribes could resist the pressure. Pre-existing Upper and Lower Creek factionalism, exacerbated in the Red Stick War, now focused on a new issue. Upper Creeks, rallying to such spokesmen such as opothleyahola of Tuckabatchee Town, opposed removal and called on both the United States and the Lower Creeks to honor the old treaties. They resisted all the blandishments of commissioners sent out from Washington in 1824 to negotiate an exchange of remaining Creek lands in the east for new lands in the Indian Territory west of Arkansas (today's Oklahoma). ${ }^{28}$

But Lower Creeks, believing that resistance was futile, were more amenable. After the Red Stick War they recognized William McIntosh of Coweta Town as their leader. Related to several well-placed men in the Georgia state government, McIntosh used his membership in the Wind clan and his oratorical ability to become hothlibonaya for the Lower towns. He emerged from the war on the side of the victors; furthermore, the 
whites identified him as the man with whom they could deal. ${ }^{29}$

But McIntosh now found himself in a quandary: In 1811 he supported in the Creek council passage of a law that imposed the death penalty for signing a treaty for an unauthorized sale of national land. Yet in 1824 the Federal commissioners called for the sale of more Creek land and offered him a generous bonus for his acquiescence. Eventually McIntosh and several lesser personages with little authority signed the proffered treaty, and the Creek council condemned McIntosh to death. A party of one hundred warriors surrounded the McIntosh house and allowed all but McIntosh himself and one follower to leave. The executioners set fire to the house and shot the two men as they tried to escape the flames. Among those who escaped was young Chilly McIntosh, a son of William, whose light complexion helped him pass as a white man. Within the next two days Creeks executed Sam Hawkins, a son-in-law of Chief McIntosh; and Hillabees attempted to shoot his brother Ben, both sons of Sarah Grierson Hawkins. 30

These executions sent a wave of fear through the Creek country, especially among the whites living there, in spite of the creek council's explanation that it was merely enforcing its own laws. No general uprising was imminent. The executions gained the attention of the John Quincy Adams administration, and it then rejected the McIntosh treaty to continue negotiations with the creek council. 31

But the American Congress and public did not give up on the goal of removal, and the administration of Andrew Jackson was even more adamant that all the Indians east of the Mississippi River be removed to the west. On March 24, 1832 the chiefs of the Creeks reluctantly signed a 
second removal treaty. Included was the promise,

The Creek country west of the Mississippi shall be solemnly guaranteed to the Creek Indians, nor shall any state or Territory ever have a right to pass laws for the government of such Indians, but they shall be allowed to govern themselves, so far as may be compatible with the general jurisdiction which Congress may think proper to exercise over them. 32

The signing of this treaty did not end the problems of the Creeks. The process of removal began; but bloodshed, dispossession, and despair sullied it. A preliminary census showed Upper Creeks numbered 14,142 with 445 slaves; Lower Creeks numbered 8,552 with 457 slaves. Creeks were to choose individual allotments to which they expected to receive title in fee simple in five years with the remainder of their lands to be opened for white settlement. But white intruders did not wait for the completion of the lengthy removal process. They swarmed into the Creek country, stealing stock, defrauding Creeks of their allotments, and generally harassing them. Some fought back and a new Creek war broke out in 1836 with some Creeks helping the Americans round up resisting fellow Creeks. But in the end Federal troops forced both "hostiles" and cooperating Creeks west over the "Trail of Tears." 33 According to oral traditions as well as Federal Government reports, the removal was not orderly. Rather, one survivor recalled, soldiers without warning forced families into overloaded wagons and delivered them to stockades. There they awaited deportation for weeks or months. An "awful silence" hung over the bereft and bewildered Creeks incarcerated in the stockades. One survivor recalled:

Times became more horrible after the real journey was begun. Many fell by the wayside, too faint with hunger or too weak to keep up with the rest.... A crude bed was quickly prepared for sick and weary people. Only a bowl of water was left within the reach, thus they were left to suffer and die alone. 
The little children piteously cried day after day from weariness, hunger, and illness.... [They were] left without father and mother--crying could not bring consolation to these children. The sick and the births required attention, yet there was no time or no one was prepared. Death stalked at all hours, but there was no time for proper burying or ceremonies. 34

Another lamented, "I have no more land, I am driven away from home, driven up the red waters, let us all go, let us all die together." 35

Die they did--of illness, of childbirth, of weariness, of despair, of drowning in the Mississippi River when the steamboat Monmouth sank. The loss of life was such that of 22,694 enumerated in 1832 , a total population of only 13,537 Creeks survived in 1859, a decline of at least 40 percent even after two decades of recovery. 36

In the Indian Territory these later immigrants joined the McIntosh faction, that had left the old Creek country about 1827 and settled in the vicinity of Three Forks, the junction of the Grand, Verdigris, and Arkansas rivers (present-day Muskogee, Oklahoma). (See Figure 2.) This faction traveled at their own expense by riverboat up the Arkansas and by covered wagon, some thirteen hundred persons in all, mostly mixedblood families such as the Stidhams, Kennards, and Harrods (Herods) with their slaves. Among them were several Graysons, including Katy and her husband Tulwa Tustunuggee. These Lower Creeks laid out new plantations in the rich river bottoms of today's eastern Oklahoma. Here they set up a government under the leadership of Roley (Roderick) McIntosh, younger half-brother of the assassinated William. Because the Cherokees also claimed the land on which they settled, in 1833 the two nations compromised and reset their boundaries. The Creeks retained the Arkansas River Valley roughly to the mouth of the Cimarron River near present-day 
Figure 2. The Creek Nation about 1856. 


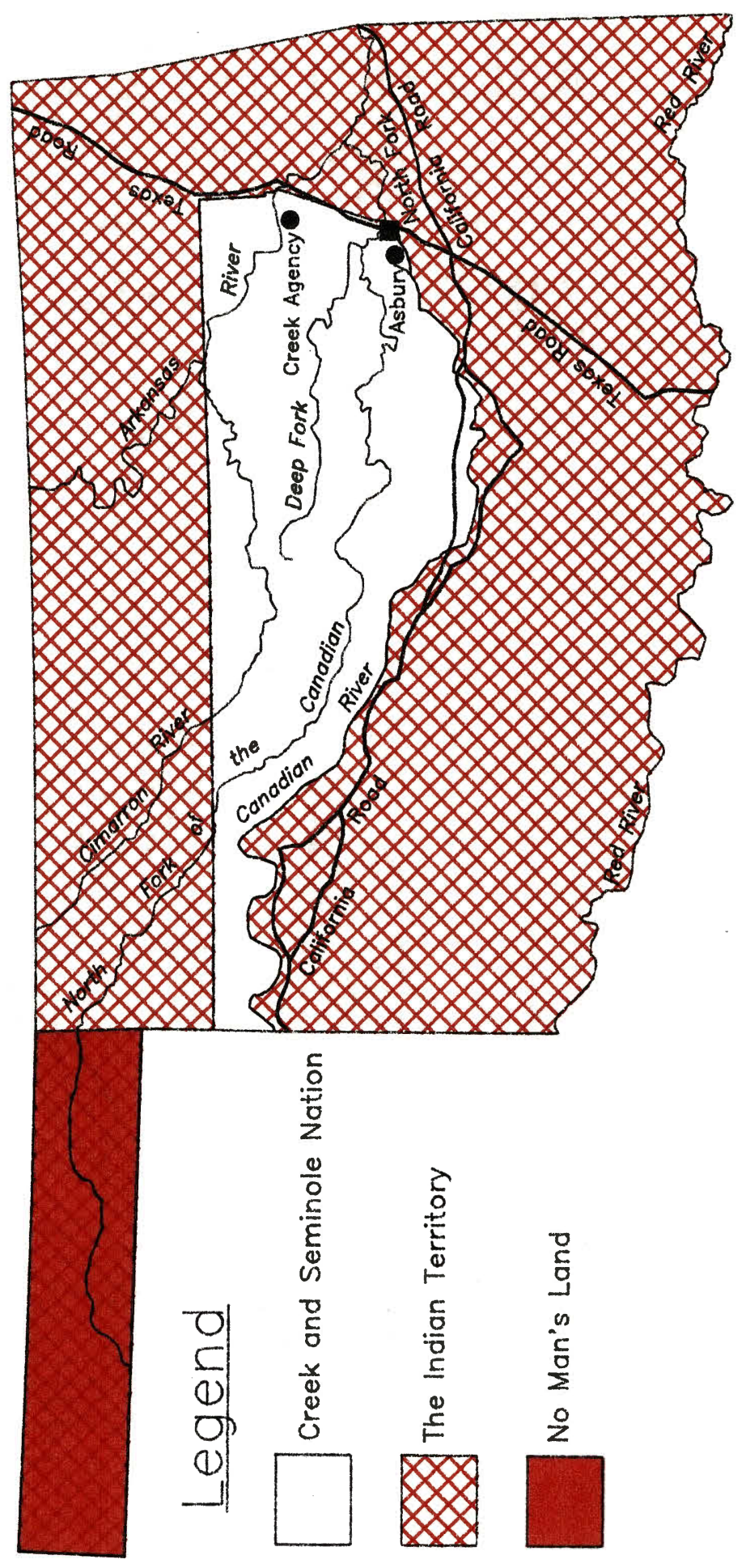


Tulsa, Oklahoma. From there the northern boundary stretched west to the 100th meridian and Mexico. To the south the Canadian River divided

Creek lands from those of the immigrating Choctaws and Chickasaws. 37

The two factions of Creeks--resident McIntosh Lower Creeks and newcomer Upper Creeks--met with a degree of mutual hostility and apprehension. Circumstances beyond their control forced them to share the Indian Territory lands assigned to them as a nation. For the present the Upper Creeks were disposed to defer to the Lower Creeks. In the meantime they settled west and southwest of the McIntosh Creeks, laying out new square grounds and lighting new ceremonial town fires in the valleys of the North and South Canadian rivers. As the several parties of immigrants arrived, the nation tallied the appalling losses the Creek nation had suffered in the course of removal. Nor did the deaths cease. The Federal Government fulfilled its promises to provide subsistence for one year inadequately if at all. The immigrants threw up rough shelters and hunted with bows and arrows in the game-rich woodlands; but malaria, privation, apathy, and other diseases of the body and spirit continued to debilitate and demoralize the nation for some time. 38

Still the Creeks did not resign themselves to extinction. Their three hundred years of contact with Europeans and even more traumatic, if shorter term, contact with the United states left them with a small fraction of their ancient strength. It modified for better or worse their life-style, bloodlines, and political organization. But many basic components still operated. Their agriculture was on a par with that of their white neighbors. Their new landbase was impressively large, more than adequate for their needs, and now included great 
expanses of natural prairie well-suited to grazing. Christian missionaries who had to this point made a minimal impact on the Creeks were eager to offer new hope, education, support, and reinforcement of traditional values. Creek experiences elevated some leaders and suppressed others while factionalizing the tribe; but here, too, the old flexible system absorbed the shocks without crumbling. The inclusive character of Creek culture continued, and the town and clan structure still provided a sense of continuity and identity for the surviving individual. 39

This was not to say that removal did not leave its legacy of bitterness. The traditional form of oratory employed on formal occasions such as council openings and treaty negotiations recalled the ancient times and reviewed historic events. No Creek who heard these speeches was ignorant of who his people were, how powerful and respected they had been, or of the calamities that had overtaken them. Furthermore, the elder generation transmitted the same information in story form to children and grandchildren. This was the case for George Washington Grayson, born in the Creek Nation in the Indian Territory within a decade of the arrival of the Upper Creeks, when the memories were still fresh, sharp, and painful. They colored his perception of whites for the rest of his life. 40

Born as the Creek nation struggled to rebuild itself in the west, soldier in the Civil War that devastated the nation once again, witness to the Reconstruction that stripped the Creeks of half their domain, rear guard in the final assault on Creek sovereignty, he never forgot the broken promises and that "the all-absorbing cupidity of the white 
race" 41 was a constant in Indian-white relationships. Nor did he miss the irony that whites scorned Indians as "savages" while behaving in a savage manner toward Indians. From within the dynamic, inclusive Creek culture, he accepted what he found good in white civilization and used it to his advantage; but he feared and resisted as long as possible submerging his and his nation's identity in that alien flood. ${ }^{42}$ 
NOTES

${ }^{1}$ George Washington Grayson, untitled manuscript (property of Mrs. Mildred Fuller Ewens, Eufaula, Oklahoma).

${ }^{2}$ Photograph number 1116, Smithsonian Anthropological Archives, Museum of Natural History, Washington, D.C.

${ }^{3}$ Grayson, untitled manuscript.

${ }^{4}$ Ibid.; W. David Baird, ed., A Creek Warrior for the Confederacy: The Autobiography of Chief G. W. Grayson, The Civilization of the American Indian, volume 189 (Norman: University of Oklahoma Press, $1988), 8-9$.

${ }^{5}$ John R. Swanton, "Social Organization and Social Usages of the Indians of the Creek Confederacy," Forty-second Annual Report of the United States Bureau of American Ethnology (1924-1925) (Washington, D.C.: Government Printing Office, 1928), 307; Morris Edward Opler, "The Creek 'Town' and the Problem of Creek Indian Political Organization," in Human Problems in Technological Change: A Casebook, ed. Edward H. Spicer (New York: Russell Sage Foundation, 1952), 171.

6 "Part of the Melish Map of 1814, Covering the Seat of War between the Creek Indians and the Americans in 1813-14," plate 8, in John R. Swanton, Early History of the Creek Indians and Their Neighbors, Bulletin 73, Bureau of American Ethnology, Smithsonian Institution (Washington, D.C.: Government Printing Office, 1922). 
7Opler, "The Creek 'Town'," 165-171; Angie Debo, The Road to Disappearance: A History of the Creek Indians, The Civilization of the American Indian Series (Norman: University of Oklahoma Press, 1941), 45.

8opler, "The Creek 'Town',' 171.

${ }^{9}$ Michael D. Green, The Politics of Indian Removal: Creek Government and Society in Crisis (Lincoln: University of Nebraska Press, 1982), 7-8.

10Opler, "The Creek 'Town'," 174-175; Swanton, "Social Organization...of the Creek Confederacy," 67, 168-169, 228, 306; Debo, The Road to Disappearance, 14; Indian Journal (Eufaula, Oklahoma), December 15, 1911.

${ }^{11}$ Swanton, "Social Organization... of the Creek Confederacy," 323 ; John R. Swanton, The Indian of the Southeastern United States, Bulletin 134, Bureau of American Ethnology, Smithsonian Institution (Washington, D.C.: Government Printing Office, 1946), 652-653; J. Leitch Wright, Creeks and Seminoles: The Destruction and Regeneration of the Muscogulgee People (Lincoln: University of Nebraska Press, 1986), 101-127.

${ }^{12}$ Green, Indian Removal, 4. Grayson disputed the accepted theory that Creeks were so-named because they lived along the watercourses. He pointed out with some logic that most Indians found it convenient to live near water. Grayson, untitled manuscript. 
${ }^{13}$ Swanton, "Social Organization... of the Creek Confederacy," 323327 .

${ }^{14}$ Green, Indian Removal, 17-20.

${ }^{15}$ Karen Ordahl Kupperman discussed these ideas in Settling with the Indians: The Meeting of English and Indian Cultures in America, 15801640 (Totowa, N.J.: Rowman and Littlefield, 1980).

${ }^{16}$ Wright, Creeks and Seminoles, 60-61; William c. Sturtevant, ed., "Commentary" in Eighteenth-Century Florida and Its Borderlands (Gainesville: University of Florida Press, 1975), 40-47.

17 Ibid., 231, 239, 241-242. See also Jacqueline Louise Peterson, "The People in Between: Indian-White Marriage and the Genesis of a Metis society and Culture in the Great Lakes Region, 1680-1830," (Ph.D. diss., University of Illinois at Chicago Circle, 1981) and Jennifer S. H. Brown and Jacqueline Louise Peterson, eds., The New People: Being and Becoming Metis in North America (Winnipeg: University of Manitoba Press, 1985). Peterson, Brown, and others, building on the foundation laid by Marcel Giraud in Le Metis canadien: son role dans l'histoirie des provinces de l'ouest (1945), hold that children of French and Native American parents became a "new people," a hybrid of the two races. They base their conclusions on the language, livelihood, settlement patterns, religion, kinship patterns, and art forms which differentiate the parents from the metis descendants. The main institution around which the metis culture developed was the fur trade, usually dominated by the 
Hudson's Bay Company or another such monopoly. Canadians considered these metis neither white nor Native American, contributing to their sense of isolation and political discrimination. This, in turn, strengthened their sense of racial identity and political self-awareness.

18 Debo, The Road to Disappearance, 55; Green, Indian Removal, 54. ${ }^{19}$ Don Martini, Southeastern Indian Notebook: A BiographicalGenealogical Guide to the Five Civilized Tribes (Ripley, Miss.: Ripley Printing Company, 1986), 61; C. I. Grant, Letters, Journals and Writings of Benjamin Hawkins, volume I (Savannah: The Beehive Press, 1980), 15, 17-18; Baird, ed., A Creek Warrior, 17.

${ }^{20}$ Grant, Letters... of Benjamin Hawkins, volume I, 13-15, 234-235, 301.

$21_{R}$. David Edmunds, Tecumseh and the Quest for Indian Leadership (Boston: Little, Brown and Company, 1984), 151-152; Debo, The Road to Disappearance, 77-80.

${ }^{22}$ Debo, The Road to Disappearance, $78-80$.

${ }^{23}$ Grant, Letters...of Benjamin Hawkins, volume II, 651-653; interview of Mildred McIntosh Childers, 17:414, "Indian-Pioneer Papers," Works Progress Administration Project S-149, microfiche, Western History Collection, University of Oklahoma, Norman, Oklahoma (hereafter cited as $I-P P) \cdot$ 
${ }^{24}$ Grant, Letters... of Benjamin Hawkins, volume II, 651-652.

${ }^{25}$ Ibid.; Debo, The Road to Disappearance, 80 ; Baird, ed., A Creek Warrior, 17 .

26 Debo, The Road to Disappearance, 80-81; Grayson, untitled manuscript; Baird, ed., A Creek Warrior, 23-24.

${ }^{27}$ Debo, The Road to Disappearance, 82-83; Daniel F. Littlefield, Africans and Creeks: From the Colonial Period to the Civil War, Contributions to Afro-American Studies, Number 47 (Westport, Conn.: Greenwood Press, 1979), 90-91.

${ }^{28}$ Debo, The Road to Disappearance, 84-88.

${ }^{29}$ Ibid., 85-87; Green, Indian Removal, 54-55; Benjamin W. Griffith, Jr., McIntosh and Weatherford, Creek Indian Leaders (Tuscaloosa: University of Alabama Press, 1988), 46-47, 86-87.

30 Debo, The Road to Disappearance, 88-90.

31 Ibid., 90.

32 Ibid. , 90.

${ }^{33}$ Ibid. , 99, 102-103.

${ }^{34}$ Ibid., 104.

${ }^{35}$ Ibid. , 105-106. 
${ }^{36}$ Ibid. , 100-103.

37Ibid., 109-110; interview of George McIntosh, 58:319-338, interview of Richard Lewis Berryhill, 7:434-440, I-PP; John W. Morris, Charles R. Goins, and Edwin C. McReynolds, "Indian Territory, 18301855," Map 23, Historical Atlas of Oklahoma (Norman: University of Oklahoma Press, 1976, revised edition).

${ }^{38}$ Debo, The Road to Disappearance, 101-102; depositions of ArtusMicco, Chewastie Yohola, and George Shirley in Colonel Ethan Allen Hitchcock, "Report on Frauds on Immigrant Indians," Indian Affairs, volume $X$, New American State Papers (Wilmington, Del.: Scholarly Resources, Inc., 1972), 528-530.

${ }^{39}$ Debo, The Road to Disappearance, $84-85$.

40 Green, Indian Removal, 9; Grayson, untitled manuscript.

${ }^{41}$ Grayson, untitled manuscript.

42 Ibid. 
CHAPTER II

"THE RISING GENERATION OF THE CREEKS"

Had George Washington Grayson been born five years earlier, it is likely he would have found far fewer opportunities to gain the education that so influenced his life. Had he been born five years later, the Civil War might have been an equally limiting factor. As it was, Grayson was born just at the time the Creek nation emerged from the post-removal dark age and embarked on the period some historians have labeled the "golden age" of the Five Civilized Tribes. 1

According to his calculations, Grayson was born May 12,1843 at the home of his parents, James and Jennie Grayson, on Possum Creek three or four miles west of North Fork Town (just east of present-day Eufaula, Oklahoma). He was the eldest of the Graysons' five children, the others being Samuel (born in 1849), Pilot (c. 1850), Malone, Louisa, and James, Jr. His parents gave their first son the English name "Washington Grayson"; he added "George" himself while still a schoolboy. 2 Grayson's parents were survivors of the relatively less traumatic removal of the McIntosh faction of Creeks to the Indian Territory in the late 1820s. At some point the formerly Upper Creek Griersons cast their lot with the Lower Creeks. Perhaps this was because of their harsh treatment at the hands of the Red sticks in that earlier troubled time, or perhaps the shift of loyalty resulted from the marriage of Robert 
Grierson's daughter to Chief William McIntosh. At any rate a number of Graysons and their slaves migrated westward first to Arkansas and then to the Indian Territory with the McIntosh faction. However, they maintained their old ties with Hillabee Town. ${ }^{3}$

Grayson's father, James Grayson (Totka Bahi Hadjo) was the eldest son of Katy Grayson and Tulwa Tustunuggee. James followed Creek matrilineal patterns by assuming his mother's white surname as well as her membership in Hillabee Town and the Spanalgee clan. James married another mixed-blood, Jane Wynne, usually called Jennie, the daughter of John Wynne and Percinta Harrod of that prominent Creek family. Her parents brought Jennie to the Indian Territory as an infant. They died while she was still a child, leaving her and her two younger sisters in the charge of guardians. These guardians then squandered their small inheritance, so that Jennie had little of a material nature to bring to the marriage. 4

But Jennie Grayson was a member of the Tiger $\mathrm{Clan}$ and of Coweta Town. At the time of her marriage that proved to be something of an embarrassment. When her new husband took her to live near his parents on Poteau Creek in present-day southeastern Oklahoma, they found that the Upper Creek Hillabees still harbored a grudge against the Cowetas for their aid to General Jackson's troops in the Red Stick War. Though Jennie's son in later years denied that hard feelings existed within the immediate family, he noted that James, sensitive to his wife's unease, moved with her again to the vicinity of North Fork Town in the Creek Nation, a more congenial neighborhood. If Jennie's identity as a Coweta was a liability at that early time, it was also one of the foundations 
of her eldest son's rise in Creek politics. 5

Creek children in Washington Grayson's youth lived relatively free from restraints. Their elders disciplined them through stories, examples, and shaming for bad behavior, except in the most extreme cases. Katy and Tulwa Tustunuggee at some point also relocated in the vicinity of North Fork Town, living sometimes on the Choctaw side of the Canadian River and at other times on the Creek side. Besides James, Katy had nine other children by Tulwa Tustunuggee. They also lived in the neighborhood, creating with the extended families of Katy's own brothers and sisters a sizeable community of Grayson relatives. Grayson recalled many years later that at least some of the time his family lived close enough to his grandparents that he was allowed to go alone through the woods to visit them. 6

His grandfather perhaps had the greatest impression on him. Tulwa Tustunuggee was, like his wife, half-white, half-Creek. Two of his older brothers spent some time with their white relatives in Georgia and afterwards went by the names "Dick" and "Jack Benson," having assumed their mother's surname. They immigrated to the Indian Territory with Opothleyahola's party of Upper Creeks. But the two younger brothers, Emarthla Hutke (also known as "Hog Meat") and Tulwa Tustunuggee (also known as "Johnnie Benson"), those survivors of Horseshoe Bend, preferred their Creek names. Unlike Dick and Jack, who customarily spoke English and wore white-style clothing, Tulwa Tustunuggee lived and dressed in the traditional Creek way. Both he and James Grayson were dark of skin and very much creek in their appearance. 7

Tulwa Tustunuggee was also Creek at heart. Grayson remarked years 
later that his grandfather

was one of those when first I knew him who was decidedly unfriendly in his estimation of the professions and character of the white man, and whose stories of his experiences with them may have warped my youthful mind on this subject, which maturer ${ }_{8}$ years, information and reflection have failed to remove. ${ }^{8}$

During his childhood at the foot of the low, brush-covered mountains west of North Fork Town, Grayson also learned a love of the wilderness. In common with most Creek boys he learned to hunt and to feel at home in the out-of-doors, so that during his time as a confederate soldier he was competent to scout and travel alone for days through rough, unfamiliar country. In quieter times he continued to love hunting, going on week-long expeditions with friends and his brother Sam. As a youth Washington Grayson also learned the skills of a farmer. Although as an adult he lived most of his life in town or in Washington, D. C., he always had at least some land of his own under cultivation; and he always took a keen interest in weather, crops, and new varieties of plants. 9

Remaining always within a few miles of North Fork Town, James Grayson relocated his family several times. The communal land-holding system of the Creek Nation gave James, as a Creek citizen, the right to occupy, farm, and improve any land not already in use. He paid only for improvements an earlier resident made. Thus the Graysons moved from place to place until James found land that suited him and his growing family's needs. This right to use the national land meant that James Grayson, though not so wealthy as many of the Lower Creeks, provided for his family according to his own abilities and energy. The system allowed a wide economic range among Creeks from those content with 
subsistence farming, as was often the case among full-bloods, to those who amassed fortunes based on free land use. 10

Altogether, the Lower Creeks occupied an area approximately eighty miles by fifty in the rich bottom lands of the Arkansas Valley. The Perrymans, the Lewises, and the Herrods were known for their wealth. The McIntoshes were said to be worth $\$ 150,000$ while rumor had it that Benjamin Marshall, part Irish and part Creek, was the wealthiest individual with perhaps as many as one hundred slaves and a personal fortune of $\$ 50,000$. But, while Katy Grayson owned several slaves and numerous livestock, her son James owned only the man Wilson, a gift from his mother. Together James Grayson and Wilson improved and cultivated the kind of small farm typical of the creek Nation at that period. 11 The Creeks found their Indian Territory lands a good place to live once the trauma of removal receded. The easternmost sections, which Grayson knew best, alternated wooded hills with tall grass prairies and the fertile but malarial valleys of the Arkansas and Canadian river systems. These were usually sluggish, red-tinted streams, shallow and easily fordable; but in times of heavy rain their floodwaters rose quickly and washed away homes and crops. Forests of oak, hickory, and pecan provided lumber, mast for free-ranging livestock, and cover for game. 12

Further west the Cross Timbers, a band of post oak and blackjack oak, belted the Indian Territory from the Red River northward to the Kansas border. It clothed a jumble of red sandstone hills that petroleum geologists decades later recognized as an indicator of oil deposits. In some spots black outcroppings hinted at the layers of coal. 
Beyond the Cross Timbers the Creek Nation stretched on to the 100th meridian, but most Creeks left these thousands of square miles of short-grass prairie to the buffalo and the nomadic Plains tribes who hunted them. 13

Even the first Creek settlers raised more corn than they needed and sold their surplus to the contractors at nearby Fort Gibson. By 1843, the year of Grayson's birth, Creek farmers were producing beans, peas, sweet potatoes, melons, peaches, rice, and cotton. Two years later they were also growing Irish potatoes, squashes, pumpkins, apples, pears, plums, cherries, oats, and corn and were experimenting unsuccessfully with wheat. Livestock, turkeys, ducks, and geese flourished. By 1847 Creeks exported one hundred thousand bushels of corn, mostly to Ireland; and stock drovers from Illinois, Indiana, and Missouri showed interest in buying their cattle. White observers commented that the Creeks were good farmers if not very neat ones. 14

While the Lower Creeks usually farmed individually, the Upper Creeks continued to live and farm communally in the Canadian, North Fork, and Deep Fork river valleys at some distance from the potentially hostile McIntosh faction. Their aggregate towns spread over an area eighty miles by sixty. In the Canadian River bottom in 1843 several towns cooperated to create a cornfield that was eight miles long and three miles wide. To a certain extent the removal weakened old ties and customs, but Creek oral tradition maintained that there was a strong continuity of town and clan patterns, of old beliefs and customs, in spite of the disruptions. The Upper Creeks resettled in their ancient town pattern, rekindling new town fires on the ashes if not the coals of 
those they had abandoned in Alabama. As town members they continued to look after their own, protecting the widows and orphans, putting up their fences, planting their fields, and harvesting their crops so that there were no paupers among them. ${ }^{15}$

Ironically, these conservative Upper Creeks better represented the Protestant work ethic the office of Indian Affairs strove so hard to impress upon Native Americans. James Logan, Creek Agent in 1844, rated the Upper Creeks the more energetic and industrious people, removed as they were from the influence of the Cherokees and whiskey peddlars. They were also less reliant on annuities due them from the Federal Government for their lands in the east than the more indolent Lower Creeks. These Upper Creeks, particularly the Eufaulas and the Okfuskees, were Grayson's closest neighbors all his life. ${ }^{16}$

Both Upper and Lower Creeks adopted livestock raising in the east. Hogs fattened on the acorns in the Indian Territory oak forests; and the natural prairies offered good grazing for cattle, sheep, and horses. Livestock perhaps caused the Creeks to disperse their homes more than had been their custom. If such was the case, one Creek elder reflected, this did not end the town system; it just meant members traveled further to the town square ground for ceremonies. 17

By the time of the Civil War, Upper Creeks counted much of their wealth in cattle and horses. Unfortunately, the osages and the Pawnees coveted their stock. These northern tribes frequently raided the western towns, forcing the Creeks to counter with ambushes and war parties. But word soon spread across the Plains that Creeks lost none of their ferocity and skill as warriors in their removal west of the 
Mississippi River. It was better to negotiate with them than to provoke them. 18

Almost all Creeks, including the Graysons, lived in hewed log houses chinked with grass and clay. Their puncheon floors and splitshingle roofs were the hallmark of any contemporary American frontier. These homes consisted typically of two rooms with a dog-trot through the middle and a rock chimney at either end. The dwelling-place of a single Creek family sometimes deceived strangers that the cluster of buildings was a village. Besides the house and outbuildings--a smoke house, an arbor for refuge from the summer heat, a stable, and a corn crib--often there were also a separate kitchen, sleeping houses, and a cabin reserved for women experiencing their menstrual cycles. 19 The difference between the homes of wealthy and poor Creeks often lay in size of the main house and the luxury of its furnishings. Many homes boasted spinning wheels and looms. Agent Logan noted that the items in Creek households which surprised him most were the "Yankee clocks, an article not in general use among Indians." 20 These were probably less articles of necessity in that pre-industrial society than signs of status.

To some extent dress distinguished the more acculturated from the more conservative. Small creek children traditionally wore breechclouts made of skins, known as "flaps." As they grew older they graduated to long-tailed shirts and then to clothing much like their parents'. Creek women had been spinning thread and weaving cotton cloth at least since the turn of the century, but by the 1840 s many preferred to buy brightly-dyed cloth from the traders. Well-to-do creek women often wore silks and muslins cut in the latest fashions. Lower Creek men wore 
white-style hats, vests, pants, and shoes but brightened these sober outfits with ruffled calico hunting shirts. The wealthy of both sexes wore gold and silver watches, chains, rings, and other jewelry. ${ }^{21}$

But the less acculturated Upper Creek men refused to wear whitestyle trousers that they regarded as a mark of submission to the whites. 22 Lieutenant J. W. Abert, passing through the western settlements of the Creek Nation in October 1845 with a group of topographical engineers, noted that,

The Indians were dressed most tastefully. Handsome shawls were gracefully twisted around their heads. They also wore leggings and moccasins of buckskin, handsome calico shirts, and beautiful pouch[es], with broad belt[s] ornamented with massive bead work. 23

Abert commented that the Creeks' slaves dressed in the same fashion as their masters. James Grayson was probably one who scorned white-style trousers as his father did. His son recalled that James always wore a shawl fashioned into a turban. Grayson remarked that it took him some time to become "civilized" in his own dress when he first went away to the states to school. 24

Travelers through the Creek Nation in the 1840s found it a strange place, an exotic mixture of the familiar and unfamiliar, peopled by Indians who were "civilized," yet still retained many of their traditional characteristics. Often the hospitality and courtesy with which the formerly hostile Creeks met white travelers surprised them. Some spoke English, but even many of the Lower Creeks spoke only Muskogee and one of the other languages of the old confederacy. Some Creeks who found it necessary to conduct their business through an interpreter called on their slaves for assistance. 25 
Even Creek slavery was more casual than that in "the states." Creeks at that time took a more tolerant attitude toward racial differences than whites. Intermarriage with slaves and recognition of part-black children as Creeks were not uncommon. Slaves denoted status and wealth as much as they provided labor and technical skills. Recognizing the value of a slave's abilities or skills, his owner might allow him extraordinary liberties. A slave allowed to work for himself could accumulate enough money to buy his freedom and that of his family. Some became businessmen and people of property, able even to make loans to the less provident creeks. 26

White travelers also remarked on the absence of towns in the creek nation. Lower creeks did not need market towns because they could ship their plantation produce by steamboat from any one of several landings along the major rivers. Upper Creeks lived in their traditional ceremonial towns but conducted commerce at trading posts scattered throughout the western regions. A village of sorts grew up near the Creek Agency, just west of Fort Gibson at the junction of the Grand, Verdigris, and Arkansas rivers, a historic point otherwise known as Three Forks. This village enjoyed a parasitic and transitory existence whenever an annuity payment was due. At those times this village flourished with cock-fights, horseraces on Daniel N. McIntosh's oval track, and other types of vice and gambling. These activities gave the village its name, "Sodom." 27

The only other "town" in the Creek Nation as whites understood the term was North Fork Town, to which the James Grayson family moved at some time in the mid-1850s. Travelers often described it as a dense 
settlement with several stores lying in the triangle at the junction of the Canadian and the North Fork rivers. North Fork Town lay astride the Texas Road (roughly today's United States Highway 69), the main route across the Indian Territory from southeastern Kansas and southwestern Missouri to (in 1843) the Republic of Texas. The Texas Road entered the Creek Nation from Cherokee country at Three Forks, skirted southwestward across Elk Creek near Honey Springs, and forded the Canadian River into the Choctaw Nation at North Fork Town. Just beyond, the Texas Road intersected the California Road, which parallelled the Canadian River all the way to the 100th meridian. The location of these two main Indian Territory arteries through or near North Fork Town and its convenient central placement in the Indian Territory gave the settlement a commercial and political importance beyond its actual size and population. It was a major stopover for an ever-increasing number of civilian and military travelers. When the Graysons moved there, it possessed a post office designated "Micco," and by 1855 it boasted a flourishing Masonic lodge. 28

A maze of horse paths and trails connected North Fork Town and the Creek Agency with outlying settlements, ranches, and plantations. In addition to the trading posts a few blacksmith shops, ferries, and toll bridges operated in the Creek Nation. Because few Creeks as yet possessed technical skills, slaves, freedmen and licensed whites usually performed vital blacksmithing, wheelwrighting, and milling services. Whites such as Gray Eagle Scales and Frederick B. Severs also ran trading posts under permit of the Creek nation. There being no banking facilities and very little currency in the Indian Territory except at 
annuity time, most commerce took place on the barter system with sugar, salt, coffee, and clothing taken in trade. ${ }^{29}$

Some Creeks made the long journey out to the western half of the nation to confer and engage in trade with roving Plains bands and eastern immigrants, among them Kickapoos, Delawares, and Sacs and Foxes. There they traded for furs, horses, mules, and slaves--the last three usually Comanche booty captured in Mexico. Federal agents regarded such trade and diplomatic activities among these tribes with suspicion if not hostility. 30

Taken altogether, life in the Creek Nation in the 1840s and 1850s was rustic, rural, and agricultural but no harder than on any other American frontier; and it was better than on many. Federal agents professed pleasure with the way in which Creeks adjusted to life in the Indian Territory. They were well on their way to fitting into the image of the acculturated, self-sufficient small farmer so long the goal of well-meaning friends of the Indian. In three respects only did the Creeks lag behind their neighbors--the Cherokees, the Choctaws, and the Chickasaws. Their rulers and government system were not yet so democratic (or accommodating) as Washington would have liked; and the creeks were slow to accept missionaries and education. 31

While the Cherokees had a constitutional form of government since 1827, the Creeks still adhered to their antiquated (in the agents' opinion) dual chieftaincy. Roley McIntosh presided as chief of the Lower Creeks, now called Arkansas District, while the Upper Creeks, now called Canadian District, recognized several chiefs as their leaders. Each district had its own council in the first years after the arrival 
of the Upper Creeks, but about 1840 the two districts combined to form a General Council. At the meetings of the General Council at High spring, midway between the two districts, a chief of each district presided, seated side by side; but McIntosh continued to take precedence. Council members represented the towns in national deliberations, enacted laws, and then made oral reports to their respective towns. There were a great number of council members, advisors, chiefs, and town chiefs--all expecting major shares of the annuity monies the Federal Government paid out to the Creeks. 32

Agent James Logan in 1845 condemned this system as inadequate and undemocratic, particularly in the matter of distributing the $\$ 34,500$ annuity. Of the council members he said, "Generally speaking, they are extremely ignorant, are noted for their superstitious bigotry, for their old customs and ceremonies, and most bitter prejudices against all measures calculated to reform the conditions or enlighten the minds of their people." These old men opposed missionary and educational activity, fearing it would threaten their authority and traditions. They enacted fines for those who did not attend the busk, their most important ceremony, and legislated punishments against the preaching of Christianity. "Their authority," Logan wrote, "is often exerted arbitrarily and their laws are unjust and unnecessarily severe." 33

Logan's prescription for this situation was for the Federal Government to impose a written constitution, a code of laws, and an elected government on the Creeks. Then Creeks discontented with the old system could elect better officials, while per capita payment of the annuities directly to heads of families would provide a more equitable distribu- 
tion. At the same time opposition to missionary activity and education would diminish. 34

The latter opposition was unusual for one of the Five Civilized Tribes: The Cherokees, Choctaws, and Chickasaws all demonstrated a keen appreciation for education. Furthermore, Sequoyah's syllabary allowed almost all Cherokees to achieve literacy in their own language within a remarkably short time. But early attempts to set up English-language schools in the Creek Nation floundered in the late 1830s. Creek slaveowners objected to the abolitionist sentiments of some missionary teachers, and they believed that religious activities were disturbing their slaves. So, as the Upper Creeks, already hostile toward whites and their culture, arrived in the Indian Territory, Lower Creeks joined them in pressing for the expulsion of the missionaries. Education consequently suffered, too, as the missionaries who conducted classes for Creek children left the nation. ${ }^{35}$

Not all converts gave up their faith; rather they continued to worship secretly. When they were caught, they suffered the prescribed fifty lashes with inch-thick elm or hickory sprouts. Creek rowdies, including, some said, Chilly McIntosh, often broke up services and fired shots at worshippers and ministers to intimidate them. But by the mid-1840s the chiefs acknowledged that their suppression of Christianity neither stamped out the new religion nor revived the old beliefs. Besides, some chiefs themselves secretly converted. 36

Officially the Creeks did not end the ban on Christianity until 1848, but they agreed to allow Robert M. Loughridge, a Presbyterian missionary, to begin closely circumscribed work near the Cowetas' 
settlement in 1841. About that same time the Baptist and Methodist missionaries renewed their efforts to convert the Creeks either in the nation itself or at strategically located revival meetings on the borders. 37 In the summer of 1848, the Fort Smith Herald reported a protracted Baptist camp meeting on the North Fork River that lasted four days. Of the fifteen hundred persons present for sunday services, twenty-three joined the church, including "the most talented and popular chief in the nation," Chilly McIntosh. 38 "He joined before preaching on sabbath morning. He spoke loud enough in giving in his christian experience, to be heard by the whole assembly," missionary Americus L. Hay exulted. "He spoke of his conviction and sorrow for $\sin . .$. He made known that his remaining days would be devoted to the service of God. " 39

That year the Baptists, who worked mostly among the Upper Creek full-bloods of the Canadian District, reported that they had eight preachers in the Creek Nation--one white, four Creeks, three blacks--and seven churches serving 550 members. Methodists, who served converts in both districts, reported 592 members. Presbyterians made fewer but more influential converts among the Lower Creeks. All the denominations rejoiced in the conversion and training of Creek men able to minister to their own people. The Baptists were particularly proud of chilly McIntosh, his son William F. MCIntosh, and James Perryman; the Methodists, of Samuel Checote, who had been converted in Alabama before the removal. It may have been during this period that Jennie Grayson was immersed in Baptizing Creek near North Fork Town. Even though she remained a devout Baptist the rest of her life, her husband James never 
affiliated himself with a Christian church. 40

With the return of the missionaries (and perhaps instigating that return), came a renewed interest in white men's education. Some of the chiefs recognized that they needed educated, English-speaking men who could protect Creek interests before the President, the Congress, and the Indian office in Washington. Even the intransigent conservative Opothleyahola of Tuckabatchee Town told the Creek council that, although he had always opposed the white men's religion, he did not oppose their education: The Creeks needed to educate their children so that they might stand between their people and trouble. 41

Consequently, in 1847 the Creek council agreed to support both day schools and boarding schools. The Presbyterians, who already operated a boarding school at Coweta, opened a second at Tullahassee. The Methodists chose North Fork Town as the site of Asbury Manual Labor School. Neighborhood schools also proliferated, and provisions existed by which promising young men of the Creek Nation might receive an education at Choctaw Academy in Kentucky. ${ }^{42}$ with these improvements and with the pride creek parents began to show in their children's educational accomplishments, Agent Logan reported confidently, "the rising generation of the Creeks will indeed be a different people." 43 That rising generation included George Washington Grayson.

If the home of James and Jennie Grayson was much like that of their conservative Upper Creek neighbors, it was different in an important aspect: The Graysons were determined that their children should have the advantages of an English education. James Grayson spoke English well, but Jennie's English was limited and imperfect. She much pre- 
ferred to speak Muskogee, her first language. 44 James was ambitious for his children, both that they might earn their living in a less arduous way than farming and that they might also "attain to positions of honor and trust in the public affairs" 45 of the Creek Nation. Jennie's ambition was simpler: unable to read her Bible for herself, she wanted them to be able to read it for her and themselves. ${ }^{46}$

Thus, as neighborhood schools once again opened their doors to Creek children, the Graysons enrolled Sam and Washington as students. The boys had the advantage of their grandmother Katy's interest in educating her own youngest children, her daughters Caroline and Adaline. Since Katy and Tulwa Tustunuggee lived some distance out of North Fork Town on the Choctaw side of the Canadian River, Katy had some cabins built outside North Fork Town. Here she installed her school-age daughters with a slave woman to look after them; here also James Grayson sent his eldest sons to stay while attending school. ${ }^{47}$

Baptist missionary Americus L. Hay operated that school in the belief that, "ignorance... is an open door for fraud, both civil and religious."48 Consequently, in October 1849 about the time Washington and Sam enrolled, Hay reported that he and his wife were finishing their third twenty-two week school session. Their average attendance was thirty students of whom twenty were boarders. The boys learned farming, and Mrs. Hay instructed the girls in housekeeping and sewing. Academic subjects included reading, writing, spelling, arithmetic, and geography. Fourteen of Hay's students had learned to read. According to Grayson, this did not include himself; he believed he actually learned very little either in this school or the second school he attended, possibly 
Methodist, run by a Mr. Adkins. ${ }^{49}$ But Hay was proud of the progress his students were making. He wrote, "A bright day is dawning on the Creeks. Already the bright light is seen in every direction." 50 Even so, Hay believed, a manual labor boarding school would accomplish far more for the Creeks. 51

True to Hay's recommendation, Asbury Manual Labor School, in which Washington and Sam Grayson enrolled about 1856, provided the real foundation of their education. The thirty-acre site five miles north of the junction of the North Fork and Canadian rivers (later the site of Eufaula Boarding School) had the advantages of good farm land and timber as well as convenience of access. The brick and stone building, completed in 1850, stood 110 by 34 feet. Two stories high with a basement, it contained twenty-one rooms and was one of the most impressive structures in the Creek Nation. In addition to the main school building, a good log house, a smokehouse, a kitchen, a stable, and an orchard stood on the site. A few years later a two-story frame building was added. When the first stage of construction ended, the cost for building totaled $\$ 9,165$, of which the Creek Nation contributed $\$ 5,000$. Over the next several years Asbury achieved a measure of success if it never achieved the intellectual heights of the Presbyterians' Tullahassee Mission. 52

Several problems interfered with the students' abilities to learn. The degree of English the child spoke when he entered school was one factor; Grayson probably had the advantage of his schoolmates here. Disease was another. Periodic epidemics of measles and similar sicknesses swept through the crowded boarding schools with devastating if 
not lethal effect. Periodically they forced the school to suspend classes. Creek parents were fearful--with good reason--of such epidemics and wanted their children home before summer, always the sickly season, set in. They frequently came to remove their children in early summer in time for them to attend the annual busks whether or not the school year was over. 53

In fact, absenteeism was a chronic problem for all the schools. One administrator complained, "Indians let their children have their own way entirely, so every person at all acquainted with them must know."54 Indian parents "would as leave put their hands in the fire as to flog or compel [the child] to go to school against his will."55 But Grayson knew that his own father, a stern and undemonstrative parent, would not permit his sons to squander their opportunity to learn. They resigned themselves to sticking it out until the official end of the session. 56 Years later Grayson had a reputation among the Creeks as a scholar, and that was true for his mature years. But as a boy at Asbury he judged himself only an average scholar; nor did superintendent Thomas B. Ruble list him among his exemplary students. Sam Grayson, on the other hand, was a quick learner. Students at Asbury studied spelling, reading, writing, mental and written arithmetic, English grammar, physiology, natural philosophy, and algebra. On Sundays they attended Bible study and classes in vocal and instrumental music. 57

In addition, students provided agricultural labor on the school farm. Seventy-five acres produced corn, oats, millet, potatoes, and turnips, while the farmers experimented successfully with Chinese sugar cane. In the fall of 1858, probably the last year Washington Grayson 
attended Asbury, Superintendent Ruble reported,

During the fall and winter the boys helped to gather the crops, chop wood, make fires, etc.; in the spring they assist in repairing fences, cleaning up the grounds for cultivation, and do most of the hoeing in the fields and garden. Besides this, they grind nearly all the meal we use on steel mills; for this we pay them, as an inducement, ten cents per bushel. 58

Girls cleaned their own rooms, washed, ironed, sewed, and helped in the dining room. Thus, Ruble believed, he was enlightening the minds of a people "just emerging from the rubbish of ages." 59

Grayson, at the time, was not so convinced of the benefits of an Asbury education. His and Sam's primary accomplishment their first two years was to become much more proficient in Muskogee, as most of the eighty or so students spoke it much more readily than they did English. Few of his teachers made a real impression on him until W. C. Munson, a dedicated and effective educator, joined the faculty. Still, seventy years later Grayson confessed a fondness for Asbury and the hillside it sat on, a hillside he helped to clear as a schoolboy. 60

After about three years at Asbury Grayson was perhaps sixteen years old and eager to leave school and begin his life as an adult. He had probably experienced by that time his naming ceremony, the rite of passage that demonstrated his acceptance as an adult Creek male. Ordinarily parents gave a Creek infant an informal name used among his family and friends. Females kept the same name all their lives, but males in their mid-teen years received a new name at the green corn festival. 61

This festival, that Creeks called boosketa and whites corrupted to "busk," occurred in July. It was the most sacred of Creek ceremonies, 
and members of a town attended faithfully. Jennie Grayson and her children celebrated the festival with the Cowetas. After cleaning and refurbishing their square ground, town members prepared themselves physically and spiritually to eat the first of the year's corn crop. The men drank an herbal mixture called "the black drink," a strong purgative that induced vomiting to clean the physical and spiritual being. The Cowetas served the black drink in the large conch shells they had brought from Alabama and used from time immemorial. This was a time of renewal and forgiveness; singing, dancing, moral lectures, thanksgiving, and feasting highlighted the ceremonies. ${ }^{62}$

For the young man taking the black drink for the first time, it was especially significant. The elders called him out and conferred on him his adult name, drawing the syllables out in a prolonged shout. The name usually recalled some incident associated with the young man. As he grew older and earned promotion through the ranks of Creek society, a title might be added in recognition of his accomplishments. Chief Roley McIntosh conferred the name "Yaha" ("Wolf") on Washington Grayson. The name referred to an early morning deer hunt on which he killed a wolf. "Tustunugga" ("Warrior") may have been added later in reference to his service in the Confederate Army during the Civil War. For most of his adult life then, Creeks knew Grayson by his English name, sometimes shortened to "Wash," and "Yaha," a name the third generation of his descendants still wears. 63

Perhaps as a part of this new maturity Grayson eventually became restless, bored with school, and eager for more from life than Asbury could offer. Ironically, moving on to new ground meant continuing his 
schooling, but outside the Creek Nation. Since 1854 the Creek Nation, according to stipulations of the removal treaties, used a total of $\$ 4,000$ in tribal funds to maintain about fifteen young Creeks in institutions of higher education outside the Creek country. The first four young Creeks entered Arkansas College at Fayetteville and acquitted themselves well there. About 1858 the Creek Nation prepared to name a few more students to go at the nation's expense to study at Arkansas College. 64

The Graysons did not expect that their sons would merit any consideration because they believed the boys chosen would be the sons of the most influential citizens of the nation, those with the most "pull." Even when rumors suggested that a boy from Asbury would fill the last racancy, the Graysons did not expect it to be one of their sons. Consequently, they were surprised to receive notification that washington had been chosen. 65

They then considered whether the possible advantages of sending their eldest son outweighed the dangers. The opportunity for further education suited their long-held ambitions and beliefs about what would create the best future for their children. At the same time, they found it hard to think of sending their son, who had never been more than a few miles from home, all the way to "the states" to study. He would be among people not only strangers but alien in many ways. 66

Moreover, a latent danger existed. Many young men who went away to study learned too well the ways of the white people. They came home with different ideas, a different perspective on the world, and perhaps a different life-style. In 1845 Agent Logan reported the sad experience 
of a young agency employee. This young man was educated in the states and came back home planning to use his skills for the benefit of his people. But when he approached the chiefs with his ideas, they scoffed, "You advise us? You are a white man! You cannot talk Indian. If you desire to be one, pull off your fine clothes; put on a hunting shirt and leggins; go to the busk and drink the physik [black drink]; and then talk like one and we will listen to you."67 The young man took the only job open to him, agency interpreter. In his frustration and alienation, he became an alcoholic and died in a drunken brawl. What good, then, had his education accomplished? 68

When Agent Logan wrote this story, the chiefs of the Creeks were still somewhat reactionary. Unlike the Cherokees who made a place for their educated young men in the national government, the Creek hierarchy still excluded them. But in 1859, as the Graysons considered the offer, the Creek political climate was changing. Perhaps, when Washington Grayson came home from Arkansas College, he would find a welcome in the Creek political structure and a use for his education. 69

James and Jennie Grayson went through the soul-searching universal to parents. In the end they decided they could not deprive their son of this unexpected opportunity whatever the cost. Besides, Washington was eager to go. They accepted the appointment, a benefit that the grateful Grayson always believed came not because of his academic promise but because he, as much as the other appointees, had "pull": Jennie Grayson was related to recently elected Chief Motey Kennard of the Lower Creeks. 70

The trip to Fayetteville was eye-opening for Washington Grayson. 
James escorted his son to the college and saw him settled. Valentine McAnally, also sixteen and the son of James's sister Tility, went along for the adventure. By horseback the three rode northeast for several days, crossing the Cherokee Nation into Arkansas. The high point of the trip was their night's lodging at Rose cottage, the gracious plantation home of Cherokee Chief John Ross at Park Hill (near present-day Tahlequah, Oklahoma). Used to more rustic surroundings, they found it oppressively luxurious; but the chief was hospitable and talkative. ${ }^{71}$ The Grayson party excited as much curiosity among the folks of Fayetteville as that town did in them. Fayetteville with about nine hundred inhabitants had at least four times the entire population of the North Fork Town settlement. Years later Grayson was amused to recall how they craned their necks to see the upper floors of its two-story buildings while bystanders stared at James Grayson's Creek-style turban. Inquiry led them to the ten tree-covered acres of the Arkansas college campus. 72

In 1859 Arkansas College, founded by minister Robert Graham, was affiliated with the Christian Church. It stressed the "great and moral principles of the Bible" and required attendance at the church of the student's choice. Its faculty offered courses in mathematics, languages, and moral and intellectual philosophy and insisted that "Science, not Religion, [was] the special subject of instruction."73 President Graham personally welcomed the Graysons, accepted Washington's enrollment, and suggested a suitable boarding house for him. Then after one night's stay James Grayson left his son to make his own way in this alien white world. 74 
That it was strange and lonely Grayson still remembered as an old man. White boys did not speak or dress or play in the same ways his Creek friends did. Though he stood out at home among the Creeks with his pale skin, an inheritance from his mother, and dark red hair, his own eyes were used to brown skin and black hair and eyes. All his life he had a distaste for blonde features such as those of some of his new classmates. At the same time, with the acute self-consciousness of the adolescent, he was aware his new schoolmates thought he was peculiar; and he was afraid he would embarrass himself by doing or saying the wrong thing. True, other creek boys were there; but they were William MCIntosh and Eli Jacobs, sons of prominent and wealthy Arkansas District families. As such they were far enough above him socially to prevent his feeling at ease with them for some time. 75

Consequently, he retreated into a pose of aloofness behind which he studied the behavior of his schoolmates. This must have been a particularly hard period for him, for Creeks were a sociable people. Moreover, Grayson was gregarious by nature. But only when he was sure that he could conduct himself acceptably did he begin to enter fully into school and extra curricular activities. Perhaps it was also at this time that he developed his fastidious and fashionable style of dress, for after one purchase of clothing chosen more for the hard wear of the frontier than for style, he wrote that he "became more civilized and more careful of my apparel and personal appearance, and thereafter had my clothing cut and sewed by the city tailor, and in the prevailing style." 76

The Indian boys at Arkansas College lived under the careful scru- 
tiny of the Creek agent as well as President Graham. The first Creek students boarded just off the campus in the homes of Fayetteville families who served as their tutors in white manners and society. This tutorial condition was probably true for the Joe Lewis family, with whom Washington Grayson boarded. 77 Their mentors allowed the Creek boys to buy clothing, books, and school supplies from the firm. of stirman and Dickson; but Graham controlled all their purchases to guard against "habits of expense and dissoluteness." 78

Years later Grayson described Arkansas College as "a small and weak school." Yet the two years he spent there were profitable in several ways. He acquired ease in white society; and Fayetteville's "best families" welcomed him into their homes, in which he "enjoyed the amenities and hospitality of the refined."79 In his studies he was a mediocre student except in Latin, in which he excelled somewhat to his surprise, never having encountered the language before. In fact, he discovered that he had some talent for languages. Throughout the rest of his life he continued his interest in linguistics and frequently served as an interpreter. Lastly, he converted to Christianity and was immersed by William Baxter, interim president of the college. 80

Grayson's progress both in society and in his studies so gratified his parents that they had little hesitation about sending him back to Fayetteville to begin a second year of study in the fall of 1860 . But his return home at the end of the term for 1860-1861 brought to an end his formal education. His father was in failing health and now needed him to help support the family. Moreover, tensions between the North and the south in the United States threatened to escalate into war. 
That being the case, his returning to Fayetteville was out of the question. 81

When Grayson came home from school that last time, the Indian Territory was at the peak of its golden age. The five nations were prosperous and stable. Lawlessness was at a minimum. Relations among the five nations, their less acculturated neighbors, and the Federal Government were reasonably cordial. Factionalism was in remission. And each of the Five Civilized Tribes had a constitutional, republican form of government.

Aspects of this fortunate state of affairs did not come easily to the Creeks, especially their relationship with the seminoles. The Federal Government at the time of the removal attempted to settle the two nations together in the creek domain. But the seminoles feared the loss of their identity, slave property, and sovereignty as a mere faction within the greater Creek Nation. They resisted the proposed amalgamation until 1858. Then the two nations signed a treaty granting the seminoles a strip of land west and south of the creek domain between the North and South Canadian rivers. By this cession the Creeks received $\$ 1,000,000$ and the seminoles their independence. 82

Another major development was the further evolution of the creek government toward the American ideal. About 1858 the Creeks wrote a constitution and code of laws, civil, criminal, and slave. The constitution called for the election of a principal and second chief from each of the two districts with the chief of Coweta District understood as having precedence. The chiefs also chose a national speaker while the towns continued to elect their own chiefs and Council members. 83 In 
1858 Roley McIntosh, who had led the Lower Creek faction since the execution of his half-brother, stepped down, as did the elderly but greatly respected Tuckabatchee Micco of the Upper Creeks. In the places of these "remarkable men,"84 Canadian District chose Echo Harjo as principal chief and oktarharsars Harjo (Sands or Sandy Place) as second chief. Coweta District elected Motey Kennard principal chief and Jacob Derrisaw second chief. It was Kennard, a seven-foot-tall Baptist deacon, whom the Graysons credited with securing the school appointment for Washington because of his kinship with Jennie Grayson. 85

To ensure that the laws of the Creek Nation were enforced these men commanded the Lighthorse, a troop of Creek mounted police. In general the Creek Nation was an orderly and law-abiding place except for the illicit liquor trade. Once the Federal Government abandoned Fort Gibson in 1857, the job of stopping the trade became more difficult. 86 At the same time a "vicious little town" 87 grew up near the site of the fort. The most disturbing occasions were those on which the Federal Government delivered annuity or supplemental payments of national funds. Then Creeks en masse abandoned their plows and looms to gather at the Creek Agency, pay off debts to the traders, visit, and receive their shares of the national wealth. These occasions never failed to upset their agent and the missionaries, either they regarded the distribution of these funds as somehow unearned, demoralizing, and de-stabilizing or because of the riotous behavior that accompanied them. At the payment of August, 1859, Southern Superintendent Elias Rector reported, spiritous liquors were freely vended in the neighborhood, and on the ground; and, though a law prohibiting gaming was enacted and passed, 'faro' was openly dealt, and other thieving games played by the gamblers, who had resorted thither 
from Arkansas and elsewhere, as well as by the resident professors. 88

Except for these lapses, the Creeks lived peaceably and industriously and gave their agent and their chiefs relatively little trouble. Public opinion supported the laws, and an active temperance movement created a "cold water army" to aid the Lighthorse in suppressing the liquor traffic. 89

After the initial shock of the removal and reaction to it, the resilient Creek people were rebuilding and stabilizing their lives in the ways they understood. The dynamic Creek culture incorporated aspects of white culture Creeks found useful. The Creek Nation seemed well on its way toward the forms of religion, education, agriculture, and government that interested white officials and missionaries regarded as "progress" and "civilization," leading toward eventual assimilation into the larger white society. Creeks accomplished these things with white help but within their own concept and tradition of self-government. The achievements of that period of Grayson's childhood and youth truly deserved the historians' description as the "golden age." Young Washington Grayson, though, found the Creek Nation of the early 1860s quiet to the point of boredom. His two years in the states had acquainted him with a little more of the world and broadened his perspective considerably. He missed the bustle of Fayetteville and yearned for more excitement than North Fork Town could provide. But circumstances were about to send all the excitement he could want as well as to reshape the Creek Nation in a way that guaranteed his place in it. The "golden age" was ending, and the Creeks were not going to be allowed to create another. 90 
NOTES

$1_{\text {see Arrell Morgan Gibson, "The Golden Years" in Oklahoma: A History }}$ of Five Centuries, second edition (Norman: University of Oklahoma Press, 1981) and Grant Foreman, The Five Civilized Tribes: Cherokee, Chickasaw, Choctaw, Creek, Seminole (Norman: University of Oklahoma Press, 1934).

${ }^{2}$ Sam Grayson died in 1925 . Pilot Grayson, a teacher and businessman, died in 1895. Malone, a Vanderbilt University graduate, physician, and rancher, died in 1881. Louisa married Charles Smith. Mrs. Mildred Fuller Ewens, interview with the author, March 13, 1990; Greenwood Cemetery, Eufaula, Oklahoma; W. David Baird, ed., A Creek Warrior for the Confederacy: The Autobiography of Chief G. W. Grayson, The Civilization of the American Indian, volume 189 (Norman: University of Oklahoma Press, 1988), 32 .

${ }^{3}$ Interview of Joe Grayson, 33:445, "Indian-Pioneer Papers," Works Progress Administration Project S-149, Western History Collection, University of Oklahoma, Norman, Oklahoma (hereafter cited as I-PP).

4 Baird, ed., A Creek Warrior, 28-29.

${ }^{5}$ In the early 1960 s the site of North Fork Town and its low-lying environs, an area dear to Grayson's heart, were submerged under Lake Eufaula. Ibid., 30 .

${ }^{6}$ David Michael Lambeth, The World and Way of the Creek People (n.p., n.d.); "The Family of Robert Grierson and Sinoegee" (a genealogical chart 
prepared by Harold o. Hoppe, Wichita, Kansas); Baird, ed., A Creek Warrior, 32-33.

${ }^{7}$ Baird, ed., A Creek Warrior, 21-22; untitled genealogical chart of the descendants of In-fak-faph-ky and Mary Benson, Enola Shumate Collection, wHC.

${ }^{8}$ George Washington Grayson, untitled manuscript (property of Mrs. Mildred Fuller Ewens, Eufaula, Oklahoma).

${ }^{9}$ Mrs. Mildred Fuller Ewens, interview with the author, Eufaula, Oklahoma, October 9-10, 1989.

${ }^{10}$ According to local historian James E. Carey of Eufaula, Oklahoma, Grayson's childhood home, much altered, stood until 1990 in the northeast quarter of section 6 , range 16 east, township 9 north. Interview with the author, March 17, 1991. Angie Debo, The Road to Disappearance: A History of the Creek Indians, The Civilization of the American Indian Series (Norman: University of Oklahoma Press, 1941), 88; Baird, ed., A Creek Warrior, 32-33.

${ }^{11}$ James Logan to William Armstrong, September 20, 1845, Commissioner of Indian Affairs, Annual Report, 1845 (Washington, D.C.: Government Printing office, 1845), 516 (hereafter cited as AR CIA); "Retrospect of the Life and Character of Napoleon Bonaparte Moore," The Muskogee Nation (n.p., n.d.), Oklahoma Historical Society Archives, Oklahoma City, Oklahoma; Henry R. Schoolcraft, Information Respecting the History, Condition, and Prospects of the Indian Tribes of the United States: 
Collected and Prepared under the Bureau of Indian Affairs, volume I, Archives of Aboriginal Knowledge Series (Philadelphia: J. B. Lippincott, 1860), 269-270; Baird, ed., A Creek Warrior, 34.

12John W. Morris, Charles R. Goins, and Edwin C. McReynolds, "Geographic Regions of Oklahoma," Map 3, "Landforms of Oklahoma," Map 5, "Generalized Natural-Vegetation Map of Oklahoma," Map 9, Historical Atlas of Oklahoma (Norman: University of Oklahoma Press, 1976, revised edition).

${ }^{13}$ Ibid.

14 Logan to Armstrong, August 20, 1844, AR CIA, 1844-1845, 169-170.

15. L. Dawson to William H. Armstrong, September 5, 1845, AR CIA $1843,423-425$.

${ }^{16}$ Logan to Armstrong, August 20, 1844, AR CIA, 1844-1845, 169-170; Baird, ed., A Creek Warrior, 60 .

${ }^{17}$ Interview of Jesse Allen, 2:148, interview of Daniel Starr, 87:103113, I-PP; Schoolcraft, History... of the Indian Tribes, 269-270; William K. Armstrong to T. Harley Crawford, September 30, 1845, AR CIA 1845, 504509 .

${ }^{18}$ Debo, The Road to Disappearance, 131-132.

${ }^{19}$ Interview of Mildred McIntosh Childers, 17:420, interview of Mary 
Grayson, 35:461-462, interview of Sarah Fife, 30:16-18, I-PP; Logan to Armstrong, August 20, 1844, AR CIA 1844-1845, 169-170.

${ }^{20}$ Logan to samuel L. Rutherford, September 11, 1848, AR CIA 1848, 520.

21 Interview of Scott Waldo McIntosh, 58:373, I-PP; Logan to Armstrong, September 20, 1845, AR CIA 1845, 516.

22 Debo, The Road to Disappearance, 114.

${ }^{23} \mathrm{~J}$. W. Abert, Journal of Lieutenant J. W. Abert, from Bent's Fort to St. Louis in 1845, Senate Document No. 438, 29th Congress, 1st Session, October $15,18,1845$.

${ }^{24}$ Ibid.; Baird, A Creek Warrior, 50, 53.

25 Abert, Journal, October 15, 1845.

26 Debo, The Road to Disappearance, 115-116.

${ }^{27}$ Schoolcraft, History... of the Indian Tribes, 269-270; interview of Siegel McIntosh, 58:392-393, I-PP.

${ }^{28}$ Grant Foreman, The Five Civilized Tribes, 196; Grant Foreman, Down the Texas Road: Historic Places along Highway 69 through Oklahoma (Norman: University of Oklahoma Press, 1936), 41-42; Carolyn Thomas Foreman, "North Fork Town," Chronicles of Oklahoma 29 (Number 1, 1951):79111; interview of M. G. Butler, "North Fork Town;" Box 13, Grant Foreman Collection, OHS Archives. 
${ }^{29}$ Abert, Journal, October 18, 1845; Debo, The Road to Disappearance, 155, 213, 286; interview of M. G. Butler, "North Fork Town"; Logan to Armstrong, September 20, 1845, AR CIA 1845, 523.

${ }^{30}$ Logan to Armstrong, September 20, 1845, AR CIA 1845, 518; Philip H. Raiford to Superintendent John Drennen, September 15, 1851, AR CIA $1851,122-125$.

${ }^{31}$ Armstrong to Crawford, October 1, 1844, AR CIA 1844-1845, 155-156.

32 Debo, The Road to Disappearance, 123-124; Raiford to Drennen, September 15, 1851, AR CIA 1851, 122-125.

33Logan to Armstrong, September 20, 1845, AR CIA 1845, 515.

${ }^{34}$ Ibid.

35Debo, The Road to Disappearance, 118-119.

${ }^{36}$ Interview of Sandy Fife, 30:5, interview of John D. (Cap) McIntosh, 58:340-353, I-PP; Carolyn Thomas Foreman, "North Fork Town," 83.

${ }^{37}$ Debo, The Road to Disappearance, 119-122.

${ }^{38}$ Fort Smith (Arikansas) Herald, July $26,1848$.

${ }^{39}$ The Indian Advocate, August, 1848.

40 Debo, The Road to Disappearance, 120-121; Baird, ed., A Creek Warrior, 36 . 
41Debo, The Road to Disappearance, 120-121; W. B. Morrison, "Father Murrow," My Oklahoma, I (January 1928):41 in the Opothleyahola Collection, wHC.

42 Debo, The Road to Disappearance, 121-122.

43 Logan to Rutherford, September 11, 1848, AR CIA 1848, 520.

44 Grayson, untitled manuscript.

45 Baird, ed., A Creek Warrior, 36.

46 Baird, ed., A Creek Warrior, 36.

47 Ibid., 32-37; "Creek Census Roll, Old Settlers," Grant Foreman Collection, Gilcrease Museum of American History and Art, Tulsa, Oklahoma.

${ }^{48}$ The Indian Advocate, May, 1848.

${ }^{49}$ Americus L. Hay to Philip H. Raiford, October 1, 1849, AR CIA 1849, 182-183; Baird, ed., A Creek Warrior, 36-39.

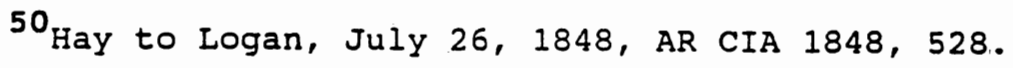

${ }^{51}$ Ibid.

52 Baird, ed., A Creek Warrior, 41-44; Thomas B. Ruble to Logan, September 8, 1848, AR CIA 1848, 525-526; Ruble to Raiford, October 8, 1949, AR CIA 1849, 184-185. 
${ }^{53}$ Ruble to Garrett, August 1, 1854, AR CIA 1854, 153-154; Ruble to Garrett, August 14, 1855, AR CIA 1855, 144-145.

54 John M. Jarner to Luke Lea, July 1, 1851, AR CIA 1851, 127.

55 J. Ross Ramsey to Raiford, August 25, 1851, ibid., 127.

56 Baird, ed., A Creek Warrior, 42.

57 Ibid., 43-44; Ruble to Garrett, August 1, 1854, AR CIA 1854, 153154; Ruble to Garrett, September 24, 1858, AR CIA 1858, 147-148.

58 Ruble to Garrett, september 24,1958 , AR CIA 1858, 147-148.

${ }^{59}$ Ruble to Garrett, August 14, 1855, AR CIA 1855, 144.

60 Baird, ed., A Creek Warrior, 41-43; Grayson to Commissioner of Indian Affairs Cato Sells, October 13, 1919, 88596-1919-Eufaula-310, Eufaula Boarding School, Central Classified Files, Bureau of Indian Affairs, Record Group 75, National Archives, Washington, D.C.

${ }^{61}$ Ibid., $44,22-23$.

62 Lambeth, The World... of the Creek People; Opler, "The Creek 'Town'," 173-174; Debo, The Road to Disappearance, 21-25.

${ }^{63}$ Interview of Sandy Fife, 30:12-13, I-PP; Debo, The Road to E:sappearance, 25; Georgianna Stidham Grayson, untitled manuscript (property of Mrs. Mildred Fuller Ewens, Eufaula, Oklahoma). 
64Debo, The Road to Disappearance, 118-119; Robert Graham to Garrett, September 8, 1855, AR CIA 1855, 139-141; Baird, ed., A Creek Warrior, 4648 .

${ }^{65}$ Baird, ed., A Creek Warrior, 47-48.

${ }^{66}$ Ibid.

${ }^{67}$ Logan to Armstrong, September 20, 1845, AR CIA 1845, 520.

${ }^{68}$ Ibid.

${ }^{69}$ The Cherokees, for instance, in 1858 employed fifteen of their high school graduates as teachers for their common schools. Elias Rector to Charles E. Mix, October 26, 1858, AR CIA 1858, 128.

${ }^{70}$ Baird, ed., A Creek Warrior, 48.

${ }^{71}$ Ibid., $48-50$.

72 Ibid., 50.

${ }^{73}$ The Arkansian (Fayetteville, Arkansas), March 19, 1859 in W. J. Lemke, Early Colleges and Academies of Washington County, Arkansas, number 6, Bulletin Series (Fayetteville, Ark.: Washington County Historical Society, 1954), 68 .

74 Robert Graham, an English immigrant, was a student of Alexander Campbell at Bethany College in West Virginia before coming to 
Fayetteville. Campbell's call for a return to simple New Testament Christianity during the second Great Awakening contributed to the development of the Christian Church, Churches of Christ, and Disciples of Christ. Lemke, Early Colleges... of Washington County, Arkansas, 15-16, 61-62; Baird, ed., A Creek Warrior, 50-51.

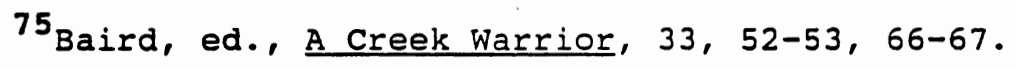

${ }^{76}$ Ibid. , 52-53.

77 Ibid., 51 .

${ }^{78}$ Graham to Garrett, September 8, 1855, AR CIA 1855, 139.

${ }^{79}$ Baird, ed., A Creek Warrior, $46,54$.

${ }^{80}$ Ibid., 53-54.

${ }^{81}$ Ibid., 53-55.

82 Debo, The Road to Disappearance, 129-130.

${ }^{83}$ Ibid. , 124-128.

${ }^{84}$ Garrett to Elias Rector, September 12, 1859, AR CIA 1859, 179.

${ }^{85}$ Ibid.; Baird, ed., A Creek Warrior, 48.

${ }^{86}$ Garrett to Rector, October 15, 1860, AR CIA 1860, 123-125; Richard C. Rohrs, "Fort Gibson: Forgotten Glory," in Early Military Forts and Posts in Oklahoma, ed. Odie B. Faulk, Kenny A. Franks, and Paul J. 
Lambert, volume $x$, The Oklahoma series (Oklahoma City: Oklahoma Historical Society, 1978), 32-34.

${ }^{87}$ Rector to A. B. Greenwood, September 20, 1859, AR CIA 1859, 159160.

${ }^{88}$ Ibid., 160.

${ }^{89}$ Garrett to Rector, September 14,1858 , AR CIA 1858, 146.

90 Baird, ed., A Creek Warrior, 55-56. 
If conditions in North Fork Town and the Creek Nation in 1861 seemed placid to young Washington Grayson, they masked a growing national anxiety and fear of impending change. Within months of his returning home, the creek Nation was caught up in the tragedy of the Civil War; and the Grayson family was uprooted and driven into exile once more. The Civil war in the Indian Territory affected everyone without regard to age, sex, or race. It was a civil war in the most elemental sense of the term.

Grayson was well-placed to witness these events; and, having reached the age of eighteen, he was legally of age to participate in them according to the Creek constitution of 1858 . On his return to the Creek Nation from Fayetteville, he found his father in declining health. But the severity of his incapacity varied, making it possible for Washington to work as a clerk in North Fork Town, first at Smith's general store and then at that of S. S. Sanger. This meant that he had access to American newspapers and heard the informal discussions of Creek affairs that took place in these gathering places. He was probably aware of the rising tensions among the Creeks. 1

These tensions stemmed from those currently dividing North and South in the United states. Although they occupied a distant frontier, 
Creeks well understood that slavery and southern secession were critical issues. And as these issues grew in prominence, Creeks hardened their own attitudes toward race while bringing their slave laws into line with those of the southern states. As did southern slave-owners, they feared the loss of their slave property should Republican presidential candidate Abraham Lincoln win in $1860 .^{2}$

But slavery was only one issue that concerned the Creeks. Equally alarming, perhaps more so, was the prospect that the Federal Government might once more dispossess them. Even though the removal treaties guaranteed the Creeks autonomy in and possession of their Indian Territory lands, they were well aware that white Americans coveted those lands. Southern Indian Superintendent Elias Rector, while paying lip service to Indian rights and title, in his 1858 report, a public document, trumpeted praise for:

the rich alluvial valleys...vast extents of the most beautiful and fertile limestone prairies; ranges of mountains abounding in minerals; lovely valleys in between; incalculable wealth of coal, limestone, and marble; salt springs, water power; everything in short that is needed to make a great and flourishing state, a great grain-producing, stock raising, vinegrowing country. ${ }^{3}$

True, he conceded, the Indian nations held this land in fee simple; but that really (his italics) implied only a usufruct right to the individual tribal citizen. Necessity, the supreme law of nations, must soon force the Federal Government to allot Indian land in severalty, give the Indian the right to sell or lease his allotment to non-Indians, and grant him United States citizenship. In the face of such magnanimity, he concluded, "how insignificant their petty nationalities and half independencies, and quasi ownership of the soil which they cannot 
alienate?"4 Subsequently in 1859 the Commissioner of Indian Affairs proposed that the Creeks allow their lands to be surveyed and allotted in severalty. 5

Sincerely dedicated to Creek welfare, missionary Robert Loughridge protested passionately, "If the desire is to destroy the Indians in the most complete and expeditious manner, this is the way to do it." If allotment took place and whites were allowed to move into the Indian Territory, one only had to look into the pre-removal history of the Creeks to know that "soon, very soon, we [would] see the great body of the Creeks wandering about, like other Indians in many parts of the State, without lands, without homes, or any means of support." Rather the Federal Government should honor its treaty obligations to protect their land, educate the rising generation, and allow them to mature into an "enlightened Christian nation." 6

Principal Chiefs Motey Kennard and Echo Harjo agreed with Loughridge for they politely but definitely refused to submit to allotment. Having tried the plan before in 1832 in the old Creek nation, they knew that the results were "evils and evils continually... The misery and punishment endured by our people growing out of sectionalization... is fresh upon our minds. Hence there is no consideration that can induce us to try the experiment again." 7 But the idea did not die; instead it re-emerged in the presidential campaign of 1860. Perhaps thoughtlessly Republican William Seward declared, "The Indian Territory...south of Kansas must be vacated by the Indians."8 Coming so soon after the commissioner's proposition, Seward's statement must have compounded the fears of Indian Territory 
residents concerning their lands, their slaves, and the Federal Government's intentions.

If fear propelled the Creeks out of the Union, shared concerns and economic ties drew them into a Confederate alliance. The Confederacy recognized that the Indian Territory had much to offer in the event that war followed secession. Its resources of grain, meat, salt, lead, and horses could supply and transport an army; many of its men were skilled and experienced guerrilla fighters. The Texas and California roads, intersecting near North Fork Town, carried a heavy volume of commercial, civilian, and military traffic. The Indian Territory was a natural buffer or, conversely, an invasion route, between secessionist and Unionist states. These considerations gave it major importance to both the Confederacy and the Union, but only the Confederacy took positive steps to secure the loyalty of its one hundred thousand inhabitants. ${ }^{9}$ From February to June 1861 representatives of the Confederacy came to centrally-located North Fork Town to woo the Creeks and their Indian neighbors. At a series of meetings these emissaries stressed the common concerns and ties that bound the Indian Territory and the confederacy, while they underscored the unreliability of the fractured Union. They persuaded a number of influential mixed-blood Creeks--Chilly McIntosh, his younger half-brother Daniel N. McIntosh, Benjamin Marshall, Chief Motey Kennard, Timothy Barnett, Samuel Checote, and George w. Stidham--that their best interests lay with the Confederacy. Their success was not complete. A number of more traditional Creeks resisted the Confederate overtures. But at that critical time the Creek chiefs sent Oktarharsars Harjo (Sands) and several prominent full-bloods out to the 
western frontier to confer with the plains tribes. In their absence the pro-Confederate faction wrote a constitution designed to create a pro-Confederate, unified Indian government for the territory. 10 While the Confederacy actively sought alliance with the Indians, the Federal Government inadvertently drove them into its arms. First it evacuated its troops from the frontier forts, leaving the Indians to defend themselves from hostile tribes and white intruders. ${ }^{11}$ Then nervous Federal officials withheld the annuity payments to keep them from falling into the hands of "armed rebels and banditti."12 such actions violated the removal treaties and the Intercourse Act of 1834 while undermining the Federal Government's credibility. In early July 1861 with many of the opposition leaders absent, the Creeks considered signing a treaty with the Confederacy. The Southern government offered to assume the treaty obligations of the United States, including the $\$ 71,960$-annuity; to protect Creek lands and property, including slaves; and to allow the Creeks and Seminoles a delegate to the Confederate Congress. Assembled in the woods west of North Fork Town on Chintz Mountain (now Foley's Mountain on the west edge of Eufaula, Oklahoma), they debated the alliance for several days in sessions that were uncharacteristically acrimonious. Opothleyahola, the long-time nemesis of the McIntoshes, argued eloquently and stubbornly that signing the proposed Confederate treaty violated the one already in existence between the Creek Nation and the United States. Seeing that he could not dissuade the pro-southern faction, he withdrew with his followers to the west. Daniel N. McIntosh, Chilly McIntosh, George w. Stidham, and Motey Kennard then signed the Creek-Confederate al- 
liance. 13

How much of this Grayson witnessed must be speculation, but it is very likely that his enjoyed a ring-side seat. Grayson was related to several of the pro-Confederate leaders and probably was acquainted with Opothleyahola, who lived only about ten miles from North Fork Town (near present-day Checotah, Oklahoma). In later years he spoke admiringly of Opothleyahola's stand in support of the old treaties, calling him, "a wise and patriotic counselor," 14 even though Grayson chose the confederate side. Also, it is unlikely that Grayson would have missed participating in what was to him and his fellow Creeks great events. It is also probable that, in after years at least, he was very familiar with the Creek-Confederate treaty and the deliberations leading to its signing, for it was in his personal library, acquired perhaps from his future father-in-law, George w. Stidham. ${ }^{15}$

Within six months of the Confederate attack on Fort Sumter, the Civil War set Creek against Creek. Opothleyahola's withdrawal from the national council at North Fork Town signaled the renewal of the removalera factionalism. Historians have since generalized that the pro-Confederate Creeks were the old McIntosh faction, the more acculturated mixed-bloods; the neutralists, later designated Loyal or Unionist Creeks, were the traditional full-bloods of the Upper Creek faction. ${ }^{16}$ A number of exceptions indicate that the problem of loyalty was much more complex. Many of the Unionist Creeks were wealthy slaveholders. Una McIntosh, William's brother, enlisted with his slaves in the Union Army. Some Creeks of black descent fought as Confederate soldiers. Grayson family members joined both factions. Simpson Grayson sold his 
slaves and fled with Opothleyahola's Loyalists. James's sister, Tility Grayson McAnally, "went North" while her son Valentine became a Creek Confederate trooper. 17

Choosing between the two sides in the war did not seem to be a problem for Washington Grayson. To some extent, his southern loyalty was obvious. He was the son and grandson of slaveholders, if slavery was the issue. In that matrilineal society, his mother's kinsmen were leaders of the Confederate faction. Somewhat complicating the issue was the Graysons'--and especially Tulwa Tustunuggee's--Upper Creek background if, as historians point out, Upper Creeks tended to follow Opothleyahola.

But not all Upper Creeks or full-blood traditionalists opposed the Confederate alliance. Grayson noted that when he enlisted with the Confederate Creek troops he joined his "old neighbors of long acquaintance" 18 in the Canadian District, the okfuskees and Eufaulas. This suggests two possibilities: These towns, being close to North Fork Town, had more contact with the Lower creeks and fell under the influence of their predominantly pro-Confederate leadership; or, living near the site of the early wartime councils, they heeded the proSouthern arguments that alliance with the Confederacy was the best way to protect themselves, their lands, and their property. To attribute similar deliberations to Washington Grayson may be stretching the facts. At eighteen he did not, perhaps, based his loyalty on patriotism, national honor, or even national defense. He may have adhered to the Confederate cause simply because of peer pressure and the knowledge that taking the warrior's path, whatever path that might be, was the next 
step upward for the creek male.

By the summer of 1861 Opothleyahola had gathered around him likeminded Creeks, Seminoles, Wichitas, Delawares, Shawnees, Kickapoos, Quapaws, Chickasaws, Cherokees, and Comanches. They wanted no part of the white men's war and chose to believe in the pledged faith of the

Federal Government. 19 Opothleyahola and Oktarharsars Harjo appealed to President Lincoln, the "Great Father," to uphold the treaties with the Creeks :

You said that in our new homes we should be defended from all interference from any people and that no white people in the whole world should ever molest us unless they came from the sky but the land should be ours as long as grass grew or waters run, and should we be injured by anybody you would come with your soldiers \& punish them, but now the wolf has come, men who are strangers tread our soil, our children are frightened \& the mothers cannot sleep for fear. 20

The old orator concluded with the plea, "keep off the intruder and make our homes again happy as they used to be." 21

But the Great Father was busy with more pressing concerns. He failed to reassure them, and a great migration began within the Indian Territory. Even though Opothleyahola, a substantial slave-holder, stood less for abolition and the Union than for protection of Creek interests, a number of runaway slaves and freedmen sought refuge in his camp on the upper Deep Fork of the Canadian River. Anticipating hostilities, some pro-Confederate Indians moved to the greater security of the Red River Valley. The exodus of these factions depopulated and transformed the prosperous and peaceful western countryside into an eerie desert in which unharvested corn and sweet potatoes lay in the fields, untended cows lowed, lonely dogs howled, and roosters crowed around abandoned dooryards. 22 
By fall Opothleyahola's following numbered some seven or eight thousand, and his intransigent presence on the western frontier concerned Confederate leaders. Should he join forces with General John C. Fremont in Missouri, their combined forces could sweep down together on the Arkansas District. Consequently, they planned an expedition designed to suppress his rebellion and break up his following. Forces at their disposal by this time included regiments from each of the Five Civilized Tribes as well as token forces from the smaller Confederateallied tribes of the territory. Choctaws and Chickasaws almost unanimously joined the Confederate alliance while the seminoles and the Cherokees, like the Creeks, divided almost equally into Confederate and Unionist factions. The Confederacy combined its allies under the Department of Indian Territory, Brigadier General Albert Pike commanding. Eventually these troops were designated the Indian Brigade and placed under the command of Cherokee Colonel (later Brigadier General) Stand Watie. 23

The expedition that went after Opothleyahola in November 1861 consisted of several Indian and Texas units in addition to Creeks commanded by Colonel Daniel N. McIntosh and Lieutenant Colonel Chilly McIntosh. At first Opothleyahola's Loyalists left a broad trail as they moved their possessions on packhorses and drove their stock before them. Three times the warriors fought off the pursuing Confederates but each time at greater cost. After a month's flight that unusually harsh December the desperate Loyalists dropped their packs and abandoned those too sick or weak to keep up. Their dead lay unburied beside a trail marked by the blood of the wounded and the footprints of those strug- 
gling barefoot through the snow. After the third fight they burned the prairie behind them to erase their trail and scattered. Then the Confederates, their own supplies and ammunition gone, gave up the pursuit, allowing the survivors to escape into Kansas. 24

The remnant, "a famishing, freezing multitude," 25 took refuge near the headwaters of the Verdigris River. Their temporary agent reported that they arrived with nothing except the clothes on their backs. "Families who in their country had been wealthy, and who could count their cattle by the thousands and horses by hundreds, and owned large numbers of slaves...were without even the necessaries of life."26 Without food, clothing, shelter, or medicine the survivors froze and starved that bitter winter while waiting for Congress to authorize spending the unpaid Creek annuities for their relief. Among the casualties in exile was opothleyahola himself, who bitterly advised Federal officials that they should show the rebel (Southern) women and children no mercy: the best way to get rid of a bad breed of dog was to kill the bitch. 27

With the war less than a year old, former missionary J. S. Murrow wrote in January, 1862:

The western portions of this Indian Territory are all ruined and laid waste. All improvements are burned, stock all driven off or killed, and the entire western settlements deserted. 'Tis sad, and made my heart ache as I beheld settlements and farms, where a few months ago families lived in plenty and pleasure, now deserted and ruined--nothing but the rock chimneys left. It seems as if the good and wise God is purposing to destroy this Indian race entirely. 28

Such devastation became the hallmark of the Civil War in the Indian Territory and particularly in the Creek Nation. Each side pledged itself initially to protect civilian life and property and to limit the 
fight to military targets, but both soon abandoned such lofty aims. Livestock, foodcrops, groceries, and other supplies were civilian property; but they were also necessities to armies on the farthest end of the Union and Confederate supply lines. Men and women also forfeited their personal inclinations to the demands of the times, and those who preferred to remain peacefully at home often had that option taken from them.

But until the middle of 1863 Southern Creeks, among them the James Grayson family, escaped the worst of the violence. Once the excitement over Opothleyahola's rebellion subsided, life was fairly peaceful. Indeed, most of the fighting in the Indian Territory through the first eighteen months of the war, took place in the eastern Cherokee Nation. There Union troops tried unsuccessfully to restore control to the Unionist Ross faction. Still, some Creeks anticipated a possible Union invasion; consequently, a leisurely migration southward continued during the early months of the war. Well-to-do Creeks sent their children to school in states they believed relatively safe from Northern invasion. They moved their slaves and portable goods to the safety of the Red River Valley. Some stayed on the Choctaw-Chickasaw side of the river while others moved on into north Texas. Washington Grayson's relative, Chief Motey Kennard, secured his property in the Red River Valley and then returned to North Fork Town to await developments. But McIntoshes, Lewises, Marshalls, and Stidhams who remained in selfimposed exile formed a Southern Creek government with George w. Stidham as principal chief. 29

James Grayson's family was not a part of this early migration. 
James died about 1860 and his widow chose to remain near North Fork Town with her three teen-aged sons and two younger children. The slave Wilson had died some time earlier, so that the work of maintaining their small farm fell on Jennie and her older sons. That and other factors kept Washington Grayson from following his own inclination to join the 1,375 Creek men already enlisted in the Confederate Army by the fall of 1861. He further justified his refusal to enlist by pointing out that Creek troops, by their treaty with the Confederacy to remain in the Indian Territory, were far from the real fighting. Nor was the Creek Nation itself threatened now that Opothleyahola was in exile in Kansas. That being the case, Grayson did not see the point of hurrying to enlist only to sit idle in camp. 30

But Grayson was highly conscious of the fact that others did not see his remaining at home in the same practical light. They murmured that as an educated young man he should be willing to serve his people as an officer in one of the Confederate Creek units. His education here involved more than mere literacy. In an army that spoke three Muskogee dialects and a number of totally unrelated languages, an officer whose fluency in the lingua franca, English, allowed him to read, write, and interpret orders was doubly valuable. But Grayson delayed enlisting. As late as April 1862, he visited William H. Rogers's general store in North Fork Town to buy staples, denim cloth, articles of clothing, and sundry items. Others who frequented the store about the same time were Chilly McIntosh, Chief Motey Kennard, George w. Stidham, ardently pro-Confederate missionary H. F. Buckner, and Confederate Creek quartermaster James M. C. Smith. They perhaps pressured him to enlist, and he 
heard talk that a lieutenancy in one the of the regiments could be created for him. Still he waited. 31

For a bored and somewhat romantic young man brought up on stories of Creek prowess in war, this must have been a galling situation. Taking up the weapons of a warrior was the traditional next step for an ambitious young man who had received his formal name at the busketa. All Grayson's life he demonstrated a militarist bent and an admiration for the warrior tradition that the realities of his military service never dimmed. In that first year of the war he was emotionally drawn to the idea of fighting for the Creek Nation and sharing the excitement of the moment while he chafed under the knowledge that others considered him a slacker and coward. He soothed his frustration during those months by promising himself that when the time came for him to enlist he would do so as a private. He would serve in that lowly capacity until he had demonstrated that his personal courage as well as his education entitled him to an officer's rank. ${ }^{32}$

True to his vow, at some time after the first of May 1862 , perhaps when the spring planting was finished, he joined the reorganized 2 nd Creek Mounted Volunteers, now commanded by Colonel Chilly McIntosh, as a private in Company $k$. He remained in the ranks for some months before consenting to be promoted; then by october 1863 he became its adjutant. The inspector who audited his papers that month remarked that the books and files in his care were in good order. ${ }^{33}$

Probably, Grayson mused years later, he accepted the promotion because the additional increase in pay would be useful to his mother. Wartime shortages by 1863 caused prices of even common items to skyrock- 
et, as hostilities disrupted the trade routes into the Indian Territory. Denim cloth that sold for fifty cents per yard before the war and which Grayson bought for seventy-five cents in January 1862 cost seven dollars one year later. Brown and bleached domestic cloth was similarly inflated in price. Common ready-made shirts and pants now sold for nine dollars each, whereas Grayson paid only five dollars for two coats early in 1862. The poorest quality home-made shoes cost twelve dollars a pair. Tobacco rose to five dollars per plug. Flour was expensive if it could be obtained at all. Even corn mean was in short supply. For the time being there were vegetables and meat enough, but such imported items as coffee and sugar were becoming luxuries. Washington Grayson as an officer could not only expect to send more money home but also to receive a larger share of goods captured from the enemy. ${ }^{34}$

As a member of the regiment he was among friends and kinsmen. Its commander, Colonel Chilly McIntosh, like Grayson was a descendant of Robert Grierson. He was also married to one of Grayson's Benson relatives. Lieutenant Colonel Pink Hawkins, Major Timothy Barnett, and Captain Goliah (Goliath) Herrod were relatives by blood or marriage. His cousin Valentine N. McAnally, who accompanied him to Fayetteville two years earlier, was there, as was Captain David Yargee, another Arkansas College student. Others of the two Creek regiments--Lieutenant Colonel samuel Checote, Lieutenant Pleasant Porter, and Jackson Lewis--became life-long associates. 35

Lewis, like Grayson, was a member of Company K. A full-blood, part Hitchita, and a member of Eufaula Town, he was a decade or so older than Grayson and a survivor of the Trail of Tears. He was one of the few 
people Grayson ever knew in the Creek Nation who understood the ancient mysteries of the Creek medicine men. As such, while officially serving first as sergeant of Company $K$ and then as second lieutenant, he was the company "medical officer," caring for both the physical and spiritual ills of the men. Grayson had the greatest respect for him. Their friendship continued when Grayson at some point moved back to the company first as its lieutenant, then as its captain, and Lewis's immediate senior officer. 36

Grayson's war and that of most Indian Territory soldiers was quite different from that of the usual Civil War soldier. Few formal battles were fought in the territory; nor ordinarily did engagements involve great numbers of troops. The entire Indian Brigade consisted of only about eight hundred men, with about two hundred of them officially in the 2nd Creek Mounted Regiment. Lack of Union activity in or near the territory and shortages of food, supplies, and fodder for the horses frequently caused the Confederate commanders to furlough most of the troops. Individuals in the informal Creek fashion also drifted away periodically for their own reasons until word came that they were needed. Then they returned to their camps and their Indian officers, who were much less perturbed by this seeming dereliction of duty than white officers. 37

Confederate Brigadier General William H. Steele wrote sourly in February 1864, "An experience of twelve months in the command of Indian country has convinced me that, with a few exceptions, the Indians are wholly unreliable as troops of the line." 38 steele had no time for either the Indian troops or the officers who commanded them whether they 
were Indian or Indianized white men such as former Choctaw Agent, now Colonel, Douglas H. Cooper. In fact, few white officers either understood or appreciated the Indian troops. In part this was a racial judgment; in part it was the result of lack of understanding for the Indian ways. 39

One who did understand was Brigadier General Albert Pike. A brother Mason to many mixed-blood Creeks, Pike persuaded them to sign the Confederate Treaty in 1861 . He reminded his senior officers that the Indian troops received little or no equipment, arms, uniforms, blankets, or tents from Confederate quartermasters. Supplies meant for the Indian troops were often diverted or siphoned off to white soldiers before they ever reached the Indian Territory. Bitterly he complained that the mules drawing his baggage train were "scarecrows... [but] considered good enough for the Indian service." 40 Frequently pay for the Indian troops was also months behind, forcing him at one point to spend $\$ 20,000$ of his own money to ensure their loyalty. But even he recognized the shortcomings of the Indian troops and particularly their officers, who and cared little for the forms and reports white officers considered a necessity. And he, too, thought of the Indian troops as undisciplined, needing the stiffening in a fight that white troops provided. 41

From the beginning Indian troops contributed to their own unmilitary image. As the promised Confederate uniforms rarely arrived, Indian troops dressed in whatever they wore as civilians or could confiscate. Grayson recalled that his troops usually "presented a very. motley appearance" and "were never very presentable."42 By the winter 
of 1864 his only protection from the cold weather was a small Mexican blanket. Whenever they caught a prisoner they stripped him of any item of clothing they could use and gave him theirs in trade. ${ }^{43}$

One of Grayson's favorite recollections was of his cousin Valentine's hat. It was standard issue from the Confederate government, made of unbleached (and, from the smell, unwashed) sheep's wool, and was conical in design once hard wear and weather reduced it to its original shape. To the apex of the crown McAnally attached a chicken hawk's feather (a traditional Creek war symbol) that he had shaved down so as to make the limber shaft sway and bob with every motion of his head. But when the opportunity came, Valentine readily traded this hat for that of a tall, gangling white prisoner. Grayson considered the white man's woebegone expression topped off by the jaunty, plumed Confederate Indian hat one of the most ludicrous sights he ever saw. 44

Less amusing was the chronic shortage of weapons. Creek troops used whatever they had or could capture. Members of Grayson's Company $K$ were equipped with sometimes unreliable flint-lock rifles, while he was proud to own a cap and ball pistol. In June 1862 Colonel Chilly McIntosh complained that his men had received only a scanty ration of sixty pounds of gunpowder. They needed one hundred guns and a blacksmith but would take what they could get. One month later Pike complained that the Indian soldiers had only about thirty-five percussion caps each. 45

Likewise, these mounted troops provided their own horses. As a cavalryman, Grayson was knowledgeable about horses, regarded his as a friend and companion, and did his utmost to see to its welfare. More than once he credited his horse with saving his life. On one occasion 
Grayson was with a foraging party gathering corn in a fenced field. Unexpectedly, Federal cavalry descended on them, cutting off his escape back through the single gate. With the rail fence was too stout to break through, he jumped his horse Rover over the bars, expecting to land on solid ground on the other side. But the brush and tall grass hid the drop-off to a deep, water-filled ravine. Instead of alighting on firm ground, Grayson and Rover tobogganed helplessly down the steep slope and landed saddle-deep in the creek. From there they easily reached dry ground and the safety of a haw thicket where they both ate their fill of the ripe fruit and "meditated on the funny things...incident to a warrior in time of general belligerency." 46

This was only one of several times Grayson found himself alone or cut off from the main body of the Indian Brigade. Brigadier General Pike understood, as most white officers did not, that Indian troops were at their best if left to fight their own kind of traditional, individualistic war. Unwilling to stand in ranks on open ground and face massed enemy or artillery fire, they were skilled guerrilla fighters and scouts. Small groups or individuals traveled easily through the rough country they knew so well; slipped up to the darkened windows of family homes; and picked up needed food, clothing, and information from friends and relatives. ${ }^{47}$ By the end of the war even white Confederate officers gave the Indian Brigade grudging respect as raiders, while Federals fumed that Watie's "700 ragamuffins" 48 stole, drove off, carried away, or destroyed at will anything in the vicinity of Fort Gibson.

The war in the Indian Territory, then, had less in common with the formalized conflict of the eastern theaters than with traditional Indian 
war. Creek troops, as they had from time immemorial, put on their warpaint before battle. Grayson remembered vividly how Jackson Lewis in his role as spiritual advisor painted their cheeks and breasts red for the warpath and black for the death they dealt to their enemies. Then he made the sign of the cross over them (perhaps a Christian innovation). Once the battle was over he made them bathe in a creek, drink water, and throw it up. Grayson's men kept a special article of warmedicine they believed gave them power and protection in battle. Grayson refused to rub it over his body and clothing as they did, not because he discounted its power but because he wanted to show that he possessed enough courage to face the enemy without it. 49

In fact, Grayson was preoccupied throughout his Civil War experience with his personal honor as a warrior and that of the Creeks under his command. While they frustrated him in failing to understand the need to drill and fight in formation, they never disappointed him when the battle became hand-to-hand. Eventually he was also satisfied that he had refuted any doubts as to his courage, at least on the part of his fellow Creeks in Company $K$. Around a campfire one evening one of his men stated casually that if their former captain lacked courage in leading them into battle they had nothing to complain of now. That quiet comment was enough assurance of his acceptance. To have said more or to have expected more would not have been the Creek way. He had earned the title tustunuggee (warrior) in their eyes. For the rest of his life, Creeks knew him as "Captain Grayson" or "Yaha Tustunuggee." Looking back at his youthful exploits with the maturity of six decades, he still took pride in his accomplishments during the war. But he was 
also forced to admit that at the time he simply was not wise enough to be frightened. 50

Grayson's initiation into the warrior's profession occurred during a period of relative quiet in the war in the Creek Nation. Through the winter of 1862 the Federals failed to curtail Confederate control of most of the Indian Territory except in the eastern Cherokee Nation. There in the preceding summer they had returned Chief John Ross and his adherents to the Unionist fold. But Ross's old enemy Stand Watie eluded them and as the symbolic and military leader of the Confederate Indians continued his vindictive raids against the Ross party. Unwilling to retreat further south and too weak to retake the Arkansas Valley, Watie's Indian Brigade, a few months after Grayson enlisted, set up winter quarters on the Canadian River. Creek troops also garrisoned Fort Gibson, at which they passed the early winter months fairly quietly and comfortably. (See Figure $3 \cdot)^{51}$

Cherokee mixed-blood missionary stephen Foreman visited the camp that December and found the Creeks "short on bread stuffs, but [with] beef a plenty. In some instances they [were] destitute of shoes and clothing." A more appalling circumstance to the pious Foreman was the riotous living that went on in the camps, especially at Fort Gibson. There he discovered dancing and drinking at "twenty dollars a bottle!" Horseracing, he fulminated, was the besetting sin.

All go to horse races, as far as I know, without any exception, Baptists, Methodists, and Presbyterians. Col. McIntosh, once a Baptist preacher, is the leader in horseracing now. Had the Federals come today many a one of the Regiment would have been killed or taken prisoner, and it would have been well enough, for it seems to me that this Regiment needs some heavy affliction to teach them their duty in guarding against the approaches of the enemy. 52 
Figure 3. Civil War Battle sites in the Indian Territory. 


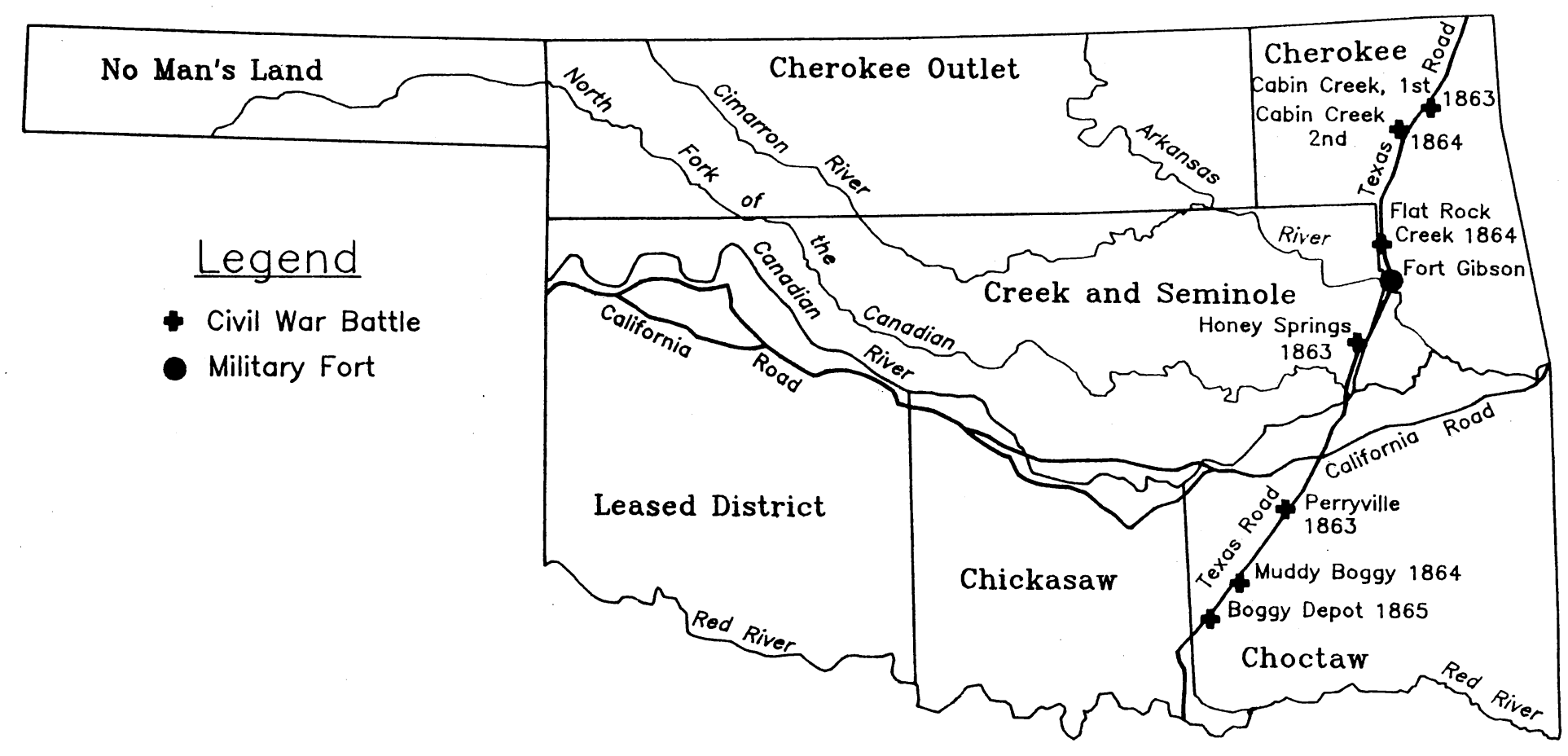


The backsliding Colonel McIntosh refused to listen to Foreman's advice to be more vigilant either morally or against the Federals. The McIntoshes also rebuffed a Federal offer to come to terms and allow opothleyahola's people to return home. 53

Then on January 10 the weather turned bitter with rain changing to snow. Four or five inches piled up, and Foreman commiserated, "The soldiers must suffer a great deal in weather such as this, because it is impossible to keep the feet dry for the snow and slop around the fire. They nearly all have good tents to screen them from the snow and rain overhead, but cannot protect their feet." 54 The next day an additional five inches of snow fell, followed by a cold wind. Twenty horses, already suffering more than the men, died from starvation. 55

Spring brought a sharp escalation of the war in the Indian Territory. In April 1863 Federal Colonel William A. Phillips reoccupied Fort Gibson as the first step toward extending his authority into the Cherokee, Creek, and Choctaw nations. As a wave of alarm swept over the Creek Nation, Confederate forces in the area congregated up on the Texas Road just north of North Fork Town. They set up a depot in the vicinity of Honey Springs (near today's Rentiesville, Oklahoma). Creek soldiers who had scattered during the winter hurried back to duty. On April 22 Cherokee, Creek, and Texas troops gathered to listen to addresses from their leaders. Chief Motey Kennard encouraged the Creek troops in their own language to fight with honor and dedication to their cause, and he thank the Texas troops for their aid, while Colonel Daniel N. McIntosh interpreted. Colonel Watie likewise spoke to the troops in Cherokee with Foreman translating. That seemed to be the official opening of the 
spring campaign. For the next several weeks Watie's men harassed Fort Gibson and its long supply line to Fort Scott, Kansas, failing on July 1 and 2 to intercept a large Federal supply train at the First Battle of Cabin Creek. Slowly the Confederates accumulated supplies and waited for reinforcements and artillery from Fort Smith, Arkansas. Their aim was to retake Fort Gibson. 56

The Federals there likewise grew stronger with the arrival of Major General James G. Blunt and reinforcements from Kansas. Aware that the six thousand Confederates over in the Creek Nation already outnumbered him two to one, he decided to attack them before their reinforcements arrived and the odds went to three to one. Consequently, on the night of July 15 Blunt left Fort Gibson, putting his force, including Unionist Creeks and former Creek slaves, across the Arkansas River. By midmorning next day the Federal troops were moving down the Texas Road toward North Fork Town. That evening and at daybreak July 17 they skirmished with Confederate scouts and found the main body of enemy troops under the command of Brigadier General Douglas H. Cooper drawn up astride the Texas Road about five miles north of the bridge over Elk Creek. Blunt deployed his army to face them. Although outnumbered, he put twelve cannon in the field to their four. 57

Grayson and the rest of the 2nd Creek Mounted Volunteers were stationed on the extreme left of the Confederate line. The coming battle was his first fight. Crouching in the dense growth of the Elk Creek bottom that damp morning, they could see little through the brush and mist but could hear the war cries of their fellow troops, the pop of small arms, and the roar of artillery. Determined and eager, they 
waited for orders to enter the fight. Before it commenced about ten o'clock, Colonel Chilly McIntosh said to them:

When you first saw the light, it was said of you "a man child is born." You must prove today whether or not this saying of you was true. The sun that hangs over our heads has no death, no end of days. It will continue indefinitely to rise and to set; but with you it is different. Man must die sometime, and since he must die, he can find no nobler death than that which overtakes him while fighting for his home, his fires and his country. 58

Grayson, perhaps because this was his first real engagement and perhaps because of his own determination to prove his courage, found his colonel's speech quite stirring. 59

Consequently, he was disappointed and frustrated when the Creeks never entered the fight; rather, they received orders to retreat without having fired a shot. In the four-hour battle, the Confederates withstood an artillery barrage and initially returned a heavy fire. Then in the confusion they misunderstood shouted Federal orders for one misplaced company of Unionist Creeks to fall back. Thinking the whole Federal line was retreating, they surged forward into the deadly fire of desperate, determined black Union troopers. Cooper, seeing the heavy losses his men were taking, ordered his artillery and troops to retreat southward across the Elk Creek bridge and to hold it while the Honey Springs depot beyond was evacuated. This they did in good order. Though he saved most of his troops, artillery, and baggage train, Cooper ordered the valuable stores of foodstuffs burned. But the Federals arrived soon enough to put out the fires and save much of the contents. 60

Later, the Confederate commanders attributed the defeat to the poor quality Mexican gunpowder supplied to the Confederate troops. Unlike 
powder imported from Europe, Mexican powder had no protective coating of graphite. It tended to absorb moisture from damp air. A heavy thunderstorm rolled through the area early that morning, leaving the humidity high and turning the gunpowder into a useless paste. But Grayson, knowing that Cooper never even ordered the Creeks into the attack, laid the loss at Honey Springs to Cooper's mismanagement of his troops. 61 The Battle of Honey Springs was the turning point of the Civil War in the Indian Territory, for Blunt used the momentum of the victory to drive on into the Creek and Choctaw nations via the Texas Road. He was not able to end all Confederate resistance, but neither could the Confederates force the Union troops out again. Eventually the Federals retook Fort Smith and the Arkansas Valley, effectively cutting the Indian Territory off from substantial Confederate support. The last two years of the war settled into the type of guerrilla raiding and harassment of Union troops and sympathizers that Watie's Indian Brigade did so well. For the remaining Southern Creeks, Honey Springs was also a turning point, escalating their nervousness into panic and setting off what was known as "the Stampede." When it was over, the Creek Nation lay virtually deserted. 62

Grayson and his fellow Creeks understood very well the import of the battle at Honey springs. When Confederate troops began withdrawing down the Texas Road, remaining Creek civilians wavered between running or staying. The more fearful expected mayhem and pillage if the Federals loosed the Unionist Indians and former slaves on them, while the more hopeful doubted they had much to fear from properly officered Federal troops. Some threw the necessities into wagons and carts and 
ran westward toward Little River, trying to find a passable ford across the flooding Canadian River; but others went only a short distance and halted to see what would happen next. Rumor had it that the Federals were as badly cut up as the Confederates in the late battle and in no condition to fight. 63

Grayson rode with the two Creek regiments some eight to ten miles north up the Texas Road to keep an eye on the Federals. On Sunday, July 19, they came back through North Fork Town, en route from scouting around Briartown, a small settlement to the east on the Canadian River. They brought with them the news that Confederate reinforcements were due momentarily and Cooper would soon reverse the Honey Springs defeat. But three days later when Cooper did indeed meet Blunt at Prairie springs, he suffered a second loss. Even so, Blunt did not immediately follow up his victories with an occupation of the Creek Nation. Rather, he waited for several weeks for reinforcements before he moved deeper into the Indian nations. 64

This left Creek soldiers and their families in a state of agitation and uncertainty exacerbated by the rumor of the fall of far-off vicksburg. Frequent alarms in the Creek camps probably heightened Grayson's worry about his unprotected family. Pickets' warnings set the troops to loading wagons, catching up and saddling horses, and emptying and reloading their guns. Then, when no attackers materialized, an uneasy calm settled in again. Many of the harried officers took comfort in whiskey. Even after the promised reinforcements arrived, talk among some of the Confederate officers was of retreat rather than attack. But Colonel Watie reportedly took a stand: The Cherokee, Choctaw, and Creek 
regiments would retreat no further; they would stay where they were. ${ }^{65}$

Watie agreed by the middle of August that Southern families should move on to the Choctaw Nation for safety. He was discouraged and placed no more confidence in the promises of Confederate aid for the Southern Indians. Watie communicated his pessimism to the Creek chief. Incompetent white Confederate officers frittered away the strength of the Indian troops, he charged, while an inferior force despoiled the Cherokee Nation. The task of saving themselves would be costly to the Indians, but, he continued:

if we possess the spirit of our fathers, and are resolved never to be enslaved by an inferior race, and trodden under the feet of an ignorant and insolent foe, we, the Creeks, Choctaws, Chickasaws, Seminoles, and Cherokees, never can be conquered by the Kansas jayhawkers, renegade Indians, and runaway negroes. 66

Moreover, he reminded the chiefs of the other Civilized Tribes that if the Cherokee Nation fell, the Creek Nation would go next, followed in turn by the remaining Indian nations. 67

Less confident and resolute, the Southern Creek and Cherokee families waited nervously. Minister Foreman wrote from North Fork Town on August 23:

We are still here but how much longer we shall remain unmolested it is difficult to tell, as almost every body feels unsafe on account of the various rumors afloat that our forces will certainly fall back, if the Feds advance on us. There was much riding about today by the creek soldiers and others, yet no one could account for it only that something was [up] more than usual.

It was probably at this time that the widow Jennie Grayson and her family decided to flee the Creek Nation. Washington on a quick trip home found them debating whether or not to join "the stampede" with their relatives and neighbors. Jennie wanted to assure the safety of 
her older sons, the most likely of her children to be swept up by either army, and thus favored sending them south with their grandparents and Uncle Watt Grayson's family. Jennie preferred to remain at home with the smaller children and hope they would not be disturbed. Washington had to agree with her. "The idea of loading into one small ox wagon a few supplies and groceries," he recalled, "that would last but a very few weeks at most, and starting out with a mother and four helpless children appeared to be going right into a state of starvation and ruin." 68 His little brother Malone cried that when the Yankees came and killed him it would hurt and he was afraid to stay. 69

In the end, though, it was Sam, the second son, now about fourteen and approaching manhood, who decided the argument. He believed the family should stay together and travel south as a unit. Washington conceded that if Sam, who would have to be the man of the family once he rejoined his regiment, was willing to take on the responsibility, the family should all go. Consequently, they hastily loaded such belongings as they could move into an ox cart and set off to join their relatives on the south side of the Canadian River. ${ }^{70}$

In retrospect Sam's judgment was wise for when the Federals finally swept into the Creek Nation late in August, events justified the Southern civilians' worst fears. Federal officers in some instances not only allowed but encouraged their men to loot and vandalize the property of Southern Creeks and Cherokees. They rounded up the remaining Creek slaves and took them back to freedom and the relative safety of Fort Gibson. They enlisted the able-bodied men in Union regiments, while the others joined the ever-growing throng of Unionist refugees clustered 
around the fort. But Creek civilians felt lucky if they escaped with a few belongings and their lives. 71

As the mass exodus moved southward, these people found plenty of vacant cabins in which to shelter. Untended gardens offered turnips, pumpkins, sweet potatoes, and late corn; abandoned hogs supplied fresh meat. 72 But if there was food enough for now, many of these refugees had little else. Stephen Foreman, writing from exile at Chickasaw Governor Colbert's place in September, 1863, described their condition:

A great many of the Creeks have also passed, on their way to some better camping place where water and grass are more abundant. Many of them are in a very destitute condition. All they are with now is a pony, one [or] two pot vessels, and a few old dirty bed clothes and wearing apparel. If they ever had any more it is left behind at the mercy of their enemies. But many who passed I was acquainted with and knew to be in good circumstances having an abundance of everything, now their all is put into one or two small wagons. ${ }^{73}$

Among these refugees were the Graysons, who eventually settled into exile in the Chickasaw Nation in the Red River Valley. ${ }^{74}$

Washington Grayson inadvertently joined the stampede as well. After seeing his family off, he searched for his regiment, only to find it scattered as other men looked to the safe removal of their families. That being the case he set off after Jennie and the children, expecting to find them just across the Canadian River at his grandmother's plantation. But they were already gone, and he failed to catch up with them. Instead he moved southward in the company of another straggler in the wake of the retreating regiments. Consequently, although within earshot of the rumbling artillery, he missed the next engagement, which occurred as Federal forces pushed down the Texas Road into the Choctaw Nation to burn the Confederate depot at Perryville. 75 
The resulting dispersal of the Confederate units sent the Creek regiments westward, while the reinforcements they so longed for in July retreated into Arkansas. The Federals followed, taking Fort Smith and thus gaining control the Arkansas River supply route into Indian Territory by september 1863. The Confederate line of defense along the Arkansas River, that had allowed Southern Creeks to remain safely in their home country, sagged further south. The Unionist half of the Creek people went into exile in 1861; now the Confederate half fled as well, leaving the Creek Nation for the last two years of the war virtually abandoned. 76

Washington Grayson's war was thus a backwater of the greater conflict, but it was no less exciting and certainly no less violent than the fighting further east. Watie's Indian Brigade, that included Grayson's regiment, constantly harassed the Federal supply lines into Fort Gibson at the same time they protected northern Texas and their own exiled families from Federal invasion, a point the new commander of the district, General Samuel Bell Maxey of Texas, well understood. The defeats of the last few months much demoralized the Indian troops, but they were still willing to fight if the Confederacy gave them and their dependents proper support. Maxey strove to keep their families fed, clothed, and sheltered in order to keep men like Grayson in the field. ${ }^{7}$

Crops were abundant the first two years of the war, but the winter of 1863 was the fiercest since 1832. Forage for cattle and horses was sparse all over the Indian Territory. Recently arrived refugees and soldiers alike felt the pinch of hunger. Their Chickasaw hosts, who at 
first welcomed them with typical Indian hospitality, began to resent the sacrifice of their herds of cattle to feed these strangers. To keep the peace and loyalty of the tribes, Maxey encouraged the refugees and the soldiers to grow their own food and fiber; but he also set up a commissary which provided flour, beef, and soap at various times to 4,823 Creek refugees in their Washita River camps. 78

With their dependents reasonably secure, the Creek troops followed Watie on guerrilla raids limited only by the scarcity of forage for their horses. A successful venture, both for Watie's Indian Brigade and for Grayson personally, took place the following summer on June 15, 1864. Having taken Fort Smith, Arkansas, the Federals planned to begin using the Arkansas River to supply Fort Gibson and its growing number of Unionist Indian refugees. When the river rose temporarily, they sent a small steamer, the J.R. Williams, upstream with a cargo of flour, bacon, fabric, boots, and a variety of other much-needed goods, some $\$ 120,000$ 's worth. The nature and timing of the shipment not being much of a secret, Colonel Watie planned to attack the steamer at Pleasant Bluff about five miles below the mouth of the Canadian River. ${ }^{79}$

Watie, according to Grayson, sent him on ahead with a detachment of three hundred men and three small cannon. At Pleasant Bluff the river curved to the south, and Grayson ordered the three small cannon hidden in the brush on the bluff overlooking the channel. He then stationed his men nearby and waited several days for Colonel watie to come. This being the first time he had commanded more men than his own company, he was excited and eager to do well. He was pleased and proud that when Watie came he approved Grayson's preparations and changed nothing. 80 
Oddly, the official accounts of the incident did not mention Grayson at all; rather, Watie's report noted that Lieutenant Henry Forrester commanded the battery. One can only speculate as to why the discrepancy exists. Perhaps Watie gave the credit to Forrester rather than Grayson because of the crucial role the artillery pieces played and the fact that the white officer was an artillery officer. One might also question Watie's giving command of three hundred men to a very young lieutenant or captain. It may have been that in this instance Grayson's fluency in both English and Muskogee gave him an advantage over more experienced and higher ranking Indian or white officers. 81 When the steamer came, the field pieces quickly disabled it. Its crew let it drift ashore on the sandbanks on the north side of the river. The small detachment of Federal guards quickly abandoned it and hurried away for help. Watie's men then overwhelmed the remaining crew and towed the steamer to their side of the river; there they stripped it and set it afire and adrift. But scouts reported a Federal column on its way well before they had the whole cargo transported to the Confederate camps. With too small a force to hold off the Federal column, Watie decided to burn the remaining goods and retreat to avoid capture. 82

But before he left he ordered Grayson to remain with a small guard from Company $K$. They were to keep watch until sundown and warn the main body of Watie's troops if the Federals arrived. Otherwise they were to rejoin the regiment after nightfall. Grayson was glad of the assignment because it demonstrated confidence in his Creeks; but he was furious when he found that his men, like many of the other Creek and seminole 
troops, were beyond his control in their eagerness to carry their plunder home. Grayson, not wanting to tell Watie that his Creeks had so far forgot themselves, let them go. Privately he was determined to carry out his orders. Consequently, as the column vanished he nervously took his place on a nearby hill as the sole sentinel. There he remained, watching the sun slide down with glacial slowness, until darkness fell and he could follow the column with the honor of the creeks at least partly in tact. 83

Although the capture of the J.R. Williams was not a complete victory for Watie's Indian Brigade, it lent encouragement to the confederate cause in the Indian Territory and demonstrated to the Federals that they must continue supplying Fort Gibson overland from Fort scott, Kansas. For Grayson and the Creeks in Watie's command this meant continued opportunities to strike in the way they knew best. So in September 1864 when Watie and General Richard M. Gano of the Fifth Texas Cavalry planned an expedition toward Fort Gibson and the supply route, Grayson was eager to accompany it. ${ }^{84}$

On September 16 the expedition crossed the Verdigris River above Fort Gibson and moved down toward the prairies intersected by Flat Rock Creek. There a party from the fort, including thirty-seven black Union soldiers, were busily cutting hay. The Federal officer in charge, Captain Edgar A. Barker, wrongly informed that only two hundred Confederates were on the way, decided the odds were about even and he should stay and fight. He had time to get his troops into a defensive position in a ravine and then, too late, learned that the confederate column consisted of two thousand troops. The confederates came down on 
his smaller party from five different directions, and after a half-hour or so Captain Barker realized that his men would soon be overrun. They and he knew that black troops could expect no quarter from the confederates, so he mounted as many as possible and charged the spot at which the Confederate attack seemed weakest. Those blacks left behind as the battle wound down hid out in the tall grass and the shallow backwaters of nearby Grand River. 85

But the Confederates hunted them like quail, according to Grayson, and showed no mercy to those they flushed out. "I confess this was sickening to me, but the men were like wild beasts and I was powerless to stop them from this unnecessary butchery," Grayson wrote later. He was able to save one white prisoner, telling his men, "it was negroes that we were killing now and not white men." 86

That night the confederates camped nearby, savoring their victory. They had burned three thousand tons of hay and the haymaking equipment. They had killed forty Federal soldiers (only four blacks escaped), and another sixty-six were missing or otherwise lost to the Union. They had captured the Union camp with its assorted loot and a number of horses and mules--all within a few miles of Fort Gibson. But the hayfield attack was only a diversion from their main goal, a supply train approaching Fort Gibson from Fort Scott. 87

The coming of this train of three hundred wagons was no more a secret than was the presence of the Confederate force sent to intercept it. Major Henry Hopkins, the commander of the train, on September 18 hurried the wagons to Cabin Creek, site of an earlier attack (July 2, 1863), at which there was a log stockade behind a number of hay ricks. 
There Hopkins circled his wagons in an arc opening onto the stockade and placed his six hundred troops within it. After midnight that evening Gano and Watie arrived within striking distance of the stockade, conferred, and decided to attack immediately. The two Creek regiments were on the extreme left end of the Confederate line as they felt their way through the darkness toward the stockade. Once in position, they were close enough to exchange insults and potshots with the defenders while waiting for enough light to see. Their initial attack forced the Federal troops facing them to give way; as the Federals retreated, the Indian troops took over the wagons. 88

Daylight allowed both sides to re-evaluate the situation. The Confederates brought their two pieces of artillery to bear and sent the Seminoles and Texas troops charging forward. Their attack nearly succeeded before being repulsed. The creek troops, meanwhile, maintained such a heavy fire that Grayson, standing in front of his company, exhorting them in Muskogee and directing their aim, was in danger of being shot accidentally as clouds of smoke and mist periodically covered him. Still resenting the doubts about his courage, he refused to heed his cousin Valentine's warning to move back to relative safety behind the line. 89

Eventually the Creeks and Seminoles exhausted their ammunition and hurried to the rear and back with fresh supplies. Their return to the firing line was the pressure needed to break the Federal resistance. At some point, Grayson's company mixed in with a group of Texas troops in the series of charges that tested the Federal lines. Unable to regroup his own scattered Creeks, Grayson surged forward with the Texans in the 
final assault. It was with them that he entered the stockade at the Second Battle of Cabin Creek, with Lieutenant Pleasant Porter, the first two Creeks to do so. 90

With the Federal troops on the run, the Confederate forces swarmed into the stockade to seize their prize. Grayson noted that all he got in the looting of the stockade was a valise containing little of value. But the wagons they had captured--130 and a herd of 750 mules--contained uniforms, blankets, liquor (which never left the battlefield), clothing, shoes, and food-- $\$ 1,500,000$ 's worth of vital supplies. Within an hour Watie and Gano headed the captured wagons homeward, deftly slipping past a weak Federal attempt to stop them. 91

Even so, it was not an easy trip back. They forced the cumbersome wagons over rough terrain and forded several streams. They crossed the Arkansas River near Tulsa and turned south into their home country. Excited but exhausted, the Confederate troops could not pause to rest even then for fear of being overtaken. Grayson noted that from the time he left camp at the beginning of the expedition he did not unsaddle his horse, and he slept away many miles in the saddle. Word of their coming went ahead, and Creek reinforcements came to meet them. Near Grayson's old home at North Fork Town, General Cooper personally welcomed them back. 92

The successful raid was a great morale booster in Confederate Indian Territory. The supplies helped keep the men in the field for several months longer. The blankets warmed their cold families in the coming winter. The coffee, sugar, rice, flour, and tea stretched their meager rations. The bolts of calico, candles, and cans of pineapple and 
oysters shared out among the officers and their wives added to the general celebration. For one young Cherokee refugee in the Choctaw Nation, the capture of the million dollar wagon train meant a new pair of shoes for which she was very grateful, even if they were of different sizes. For the hungry, sick, frightened, and war-weary Unionist refugees pinned up at Fort Gibson, however, the raid only underscored the helplessness of their condition. 93

But neither one such success nor the resolution praising Gano and Watie passed in the Confederate Congress changed the ultimate course of the war. As the winter of 1864 passed quietly into the spring of 1865, Major General Maxey did his best to assure the leaders of the Five Civilized Tribes that the Confederacy had survived the losses of New Orleans, Vicksburg, Port Hudson, Savannah, and the entire Mississippi Valley and would continue to resist subjugation. 94

But the Southern Creeks recognized that the Confederacy was beyond protecting them. Once again they must face the United States government from a posture of defeat. Even so, they did not give up hope or the will to fight. As planting time came in 1865, Creek Colonel Timothy Barnett wrote to Watie, "The men are all busily engaged in making little patches to plant something in, but are ready to go into camp when called upon--although there is great suffering among their families for something to eat." 95

Grayson, however, was not among these. He continued to accompany any raiding party that went out from the Creek camp near North Fork Town until December 1864. Shortly afterwards the mild fall weather broke and the Creek regiments moved on south to the vicinity of Wapanucka Creek in 
the Choctaw Nation for the winter. There he fell ill. Ironically, having passed through two years of raiding and four major engagements with no more injury than a powder burn, he nearly died from smallpox. Epidemics periodically ravaged the crowded camps of soldiers and refugees during the war years, adding to the general misery and high death rate. The symptoms were all too familiar. 96

Several weeks passed for Grayson in a nightmare of pain, high fever, and skin eruptions that turned him from a 170-pound man into a 100-pound scarecrow. His long, flowing, reddish hair fell out in clumps. At the depth of his month-long illness, everyone at the military hospital at Rock Academy, including Grayson, gave up hope of his recovery. He discussed his burial plans with Jennie and prepared to die, only to find that day he passed the crisis of his illness. But his recovery was so slow that, by the time he had regained his strength, news came of the surrender of Confederate forces in the east. The war was finally over. 97

It cost the Graysons and the Creek Nation dearly. The family lost old Tulwa Tustunuggee; he was buried in the Red River Valley near the grave of the youngest of Jennie's children, James Jr. The survivors eventually returned to their own country to find their old homeplace dilapidated and the fields grown up in brush. In that they were lucky: Many Creeks found nothing to return to. Soldiers of both armies routinely burned houses and outbuildings to prevent their use by the enemy. Grayson on his last raid personally set torch to the childhood home of his future wife. Creek public buildings and their prized schools were looted and misused. The once-abundant livestock of the Creek Nation 
disappeared, eaten by hungry refugees and soldiers or lost to predators, human and animal. What remained of this national wealth was stripped in the last year of the war in an organized operation that saw stolen Creek beef sold to Kansas farmers or Unionist Creeks as refugee rations. One Creek noted wryly that all that remained to the Creeks at the end of the war was their land and that only because it of all Creek property was immovable. 98

Even here the Creeks were victimized. If the Southern Creeks hoped to protect their land and property by joining the Confederacy, they were no more mistaken than the Unionist Creeks. The Federal Government, ignoring the fact that about half the Creek Nation remained staunchly loyal to their treaties and the Union, suffering much for their allegiance, took the opportunity to punish the Confederate Creeks at the same time it satisfied the land hunger of white Americans. The new treaty forced on the creek Nation in 1867 during Reconstruction compelled them to sell the western half of their lands, 3,250,000 acres, for thirty cents per acre. This area was set aside for the future resettlement of other Indian tribes. ${ }^{99}$

This, according to one of the attorneys who handled the transaction, was generous, because secretary of the Interior William Harlow believed no Indian land was worth more than the $\$ .15$ per acre the Seminoles received for their domain in the same circumstances. Nevertheless, the Federal Government then forced the seminoles to buy an additional 250,000 acres of the creeks' land at $\$ .50$ per acre. 100 Nor was the remaining Creek domain safe. Besides providing that Creek slaves be freed and made Creek citizens, the Reconstruction Treaty 
granted Creek lands as rights-of-way for one east-west and one northsouth railroad through the Indian Territory. These grants could only be consummated when the Creek national title was extinguished, Creek land was allotted in severalty, and the surplus became public domain. Herein lay the germ of the final destruction of creek rights and sovereignty. 101

To this material loss must be added loss of life and faith. A census taken in 1859 and another taken at the end of the war showed a decline in the Creek population of 24 percent, the highest death rate among the Five Civilized Tribes. If this was a "white man's war" in the beginning, it became a war of Creek against Creek and Indian against Indian. The old hatreds, stirred up in 1861, must be subdued again and unity reestablished with the war's end. Southern Creeks, including Grayson, took the first steps toward reconciliation in November 1865 by calling a meeting of both factions, but the Unionists failed to attend. One of Grayson's first actions on his return to the Creek Nation was to ride across the Arkansas River to the camps of the Loyalist Creeks to visit Simpson Grayson, his Aunt Tility, and his other relations who had "gone North." 102

Repairing such broken relationships was not easy after four years of hatred, disruption, exile, violence, death, and depredation. As the Creeks put their hands and backs into rebuilding their nation physically, the second time in a generation, some understood as Grayson did that they must also rebuild their unity with each other and with their fellow Indians. Otherwise, as Stand watie had pointed out, they would fall one nation after the other to the rapacious "inferior races."103 
NOTES

1w. David Baird, ed., A Creek Warrior for the Confederacy: The Autobiography of Chief G. W. Grayson, The Civilization of the American Indian Series, volume 189 (Norman: University of Oklahoma Press, 1988), 56-57.

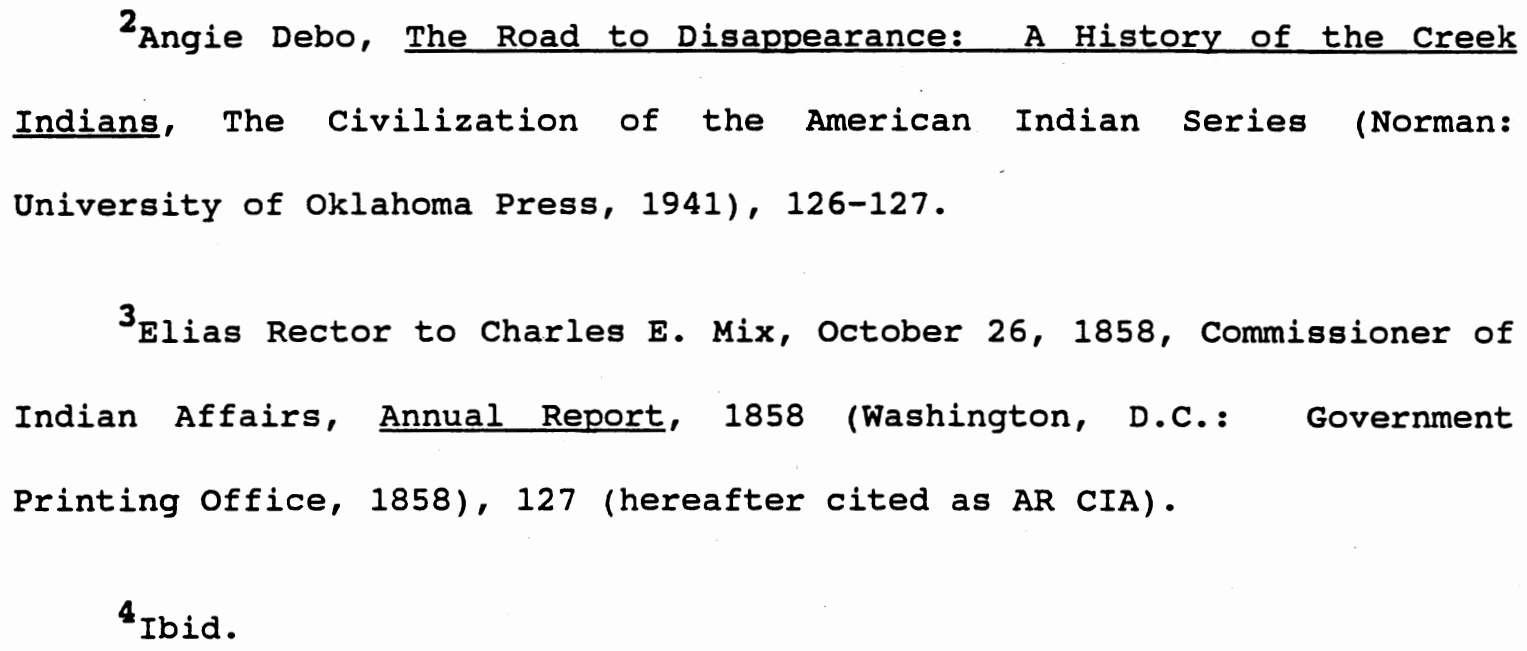

5A. B. Greenwood to Rector, November 17, 1859, Samuel Checote's Book of Records, reel 9, Creek National Records, microfilm, Oklahoma Historical Society Archives, Oklahoma City, Oklahoma (hereafter cited as CRN).

${ }^{6}$ Loughridge to William H. Garrett, September 13, 1859, AR CIA 1859, 180-182.

${ }^{7}$ Motey Carnard (Kennard) and Echo Harjo to Garrett, January 19, 1860, CRN 9.

${ }^{8}$ Quoted in Annie Heloise Abel, The American Indian as Slaveholder 
and Secessionist: An Omitted Chapter in the Diplomatic History of the Southern Confederacy (Cleveland: Arthur H. Clark Company, 1915), 58-59.

${ }^{9}$ Arrell Morgan Gibson, The American Indian: Prehistory to the Present (Norman: University of Oklahoma Press, 1980), 367; Debo, The Road to Disappearance, 142 .

10 Albert Pike to Robert Toombs, May 29, 1861, volume I, series IV, The War of the Rebellion: A Compilation of the official Records of the Union and Confederate Armies. Published under the Direction of the...Secretary of War (Washington, D.C.: Government Printing Office, 18801901), 359-361; Debo, The Road to Disappearance, 143-145.

11 Debo, The Road to Disappearance, 143-145.

12 AR CIA $1861,10$.

${ }^{13}$ Volume I, series IV, official Records, 426-443; G. W. Grayson, "Creek Biographies" file, box 6, Grant Foreman Collection, OHS Archives.

${ }^{14}$ Grayson, "Creek. Biographies" file, box 6, Grant Foreman Collection, OHS Archives.

${ }^{15}$ Vertical file, Jim Lucas Memorial Library, Checotah, Oklahoma.

${ }^{16}$ Debo, The Road to Disappearance, 144-145; Gibson, The American Indian, 367-368.

${ }^{17}$ Interviews of Scott Waldo McIntosh, 58:377, Joe M. Grayson, 35:411413, and J. W. Stephens, 87:194, "Indian-Pioneer Papers," microfiche, 
Works Progress Administration Project s-149, Western History Collection, University of Oklahoma, Norman, Oklahoma (hereafter cited as I-PP); Baird, ed., A Creek Warrior, 120.

18 Baird, ed., A Creek Warrior, 60.

${ }^{19}$ Debo, The Road to Disappearance, 150.

${ }^{20}$ Opothleyahola and Ouktahnaserharjo (Sands) to "the President our Great Father," August 15, 1861, quoted in Abel, The American Indian as... Secessionist, $245-246$ n.

${ }^{21}$ Ibid.

22D. N. MCIntosh to Colonel John Drew, September 11, 1861, box 43, volume 97, Grant Foreman Collection, Gilcrease Institute of American History and Art, Tulsa, Oklahoma; Debo, The Road to Disappearance, 167; interview of Jim Tomm, 91:323, interview of Malucy Bear, 6:179-180, I-PP.

${ }^{23}$ Colonel D. N. McIntosh to Drew, September 11, 1861, box 34, volume 97, Grant Foreman Collection, Gilcrease Institute; Colonel Douglas H. Cooper to Drew, October 29, 1861, "Creek Civil War," box 6, Grant Foreman Collection, OHS; statement of Colonel D. H. Cooper, January 29, 1862, statement of William P. Adair, R. Fields, J. A. Scales, D. N. McIntosh, James M. C. Smith, Tim Barnett, March 19, 1868, Section X, Creek Civil War, "Opothleyahola," 84-19, OHs.

${ }^{24}$ Statement of Adair et al., March 19, 1868, Section X, Creek Civil 
War, "Opothleyahola," 84-19, OHS; Debo, The Road to Disappearance, 151152.

$25_{\text {AR CIA } 1862,27 .}$

${ }^{26}$ Agent George A. Cutler to Superintendent of Indian Affairs W. G. Coffin, Southern Superintendency, September 30, 1862, ibid., 139.

${ }^{27}$ Coffin to Commissioner of Indian Affairs William P. Dole, September 24, 1863, AR CIA 1863, 176.

${ }^{28}$ Murrow to "Bro Hornaday," January 11, 1862, box 34, volume 97, Grant Foreman Collection, Gilcrease Institute.

${ }^{29}$ Interview of Jim Tomm, 92:329, interview of Richard Adkins, 1:280281, I-PP; Stephen Foreman, diary entry of April 20, 1863, Stephen Foreman Collection, WHC; Georgianna Stidham Grayson, untitled manuscript (property of Mrs. Mildred Fuller Ewens, Eufaula, Oklahoma).

30 Baird, ed., A Creek Warrior, 58-59.

31 Ibid., 59; Robert S. Boyd Collection, OHS Archives.

32 Baird, ed., A Creek Warrior, 60.

${ }^{33}$ Robert S. Boyd Collection, OHS Archives; application of G. W. Grayson to the United Daughters of the Confederacy for the Southern Cross of Honor, January 1, 1905 (property of Mrs. Mildred Fuller Ewens, Eufaula, Oklahoma); monthly inspection report of the second Creek Regiment of Mounted Volunteers, October 31, 1863, reproduced in Annie Heloise Abel, 
The American Indian as Participant in the Civil War (Cleveland: Arthur H. Clark, 1919), facing 244.

34 Baird, ed., A Creek Warrior, 61; Robert S. Boyd Collection, OHS Archives; Stephen Foreman, diary entries of January 26, March 7, April 11, 1863, Stephen Foreman Collection, WHC.

35"The Family of Robert Grierson and Sinoegee," (a genealogical chart prepared by Harold 0 . Hoppe, Wichita, Kansas; untitled genealogical chart of the family of In-fak-faph-ky and Mary Benson, Enola Shumate Collection, WHC; interview of Mrs. F. H. A. Ahrens, 1:312-313, I-PP; monthly inspection report of the second Creek Regiment of Mounted Volunteers, October 31, 1863, in Abel, The American Indian as Participant, facing 244.

${ }^{36}$ Jerlena King, "Jackson Lewis of the Confederate Creek Regiment," Chronicles of Oklahoma 41 (Spring 1963):66-69.

${ }^{37}$ General order No.___. June 23, 1862, volume XIII, series I, Official Records, 839-840.

${ }^{38}$ Report of Brigadier William Steele... of Operations in the Indian Territory in 1863, part I, volume XXII, series I, official Records, 35.

${ }^{39}$ Ibid.; Brigadier General Richard M. Gano to Brigadier General Samuel Bell Maxey, June 21, 1864, Samuel Bell Maxey Collection, Gilcrease Institute.

${ }^{40}$ Pike, unaddressed, May 4, 1862, volume XIII, series I, ibid., 823. 
41 Ibid., 820-823; Pike to Secretary of War George Randolph, June 27, 1862, ibid., 847 .

42 Baird, ed., A Creek Warrior, 97.

43 Ibid.

44 Ibid., 97-99.

45"G. W. Grayson," file, box 6, Grant Foreman collection, OHS Archives; McIntosh to Pike, June 9, 1862, volume XIII, series I, Official Records, 853.

${ }^{46}$ Baird, ed., A Creek Warrior, 79-81.

${ }^{47}$ Pike, unaddressed, May 4, 1862, volume XIII, series I, Official Records, 819; interview of Bell Haney Labor Airington, 1:350, I-PP.

${ }^{48}$ Agent Justin Harlan to Coffin, August 8, 1863, AR CIA 1863, 215.

${ }^{49}$ John R. Swanton, "Social Origins and Social Usages of the Indians of the Creek Confederacy," Forty-second Annual Report of the United States Bureau of American Ethnology (1924-1925) (Washington, D.C.: Government Printing office, 1928), 436; Baird, ed., A Creek Warrior, 102-103.

50 Baird, ed., A Creek Warrior, 85, 106-107.

$51_{\text {Lary C. Rampp and Donald L. Rampp cover these events in The Civil }}$ War in Indian Territory (Austin: Presidial Press, 1975), 1-29. 
52 Stephen Foreman, diary entries of December 25, 1862, January 10, 1863, Stephen Foreman Collection, WHC.

53 Ibid.

54 Ibid., January 14, 1863.

55 Ibid. , January 15, 1863.

${ }^{56}$ Ibid., April 19, 22, 1863; LeRoy H. Fischer, The Battle of Honey Springs (Oklahoma City: Oklahoma Historical Society, 1988), 2.

57Fischer, The Battle of Honey Springs, 2; Rampp and Rampp, The Civil War in Indian Territory, 21-22.

58 Baird, ed., A Creek Warrior, 62-63.

${ }^{59}$ Ibid., 62.

${ }^{60}$ Ibid., 61-63; Fischer, The Battle of Honey Springs, 3-7; Cooper to Steele, August 18, 1863, volume XXII, series I, Official Records, 457461 .

${ }^{6} 1_{\text {Report of }}$ Brigadier General William Steele, February 14, 1864, volume XXII, series I, Official Records, 33-34; Second Re-enactment of the Battle of Honey Springs, July 15, 1990; Baird, ed., A Creek Warrior, 61.

${ }^{62}$ Fischer, The Battle of Honey Springs, 7 ; Rampp and Rampp, The Civil War in Indian Territory, 53. 
${ }^{63}$ Stephen Foreman, diary entries of July 18, 19, 29, 1863, stephen Foreman Collection, WHC.

64Ibid., July 19, 1863; Baird, ed., A Creek Warrior, 63n.

${ }^{65}$ Stephen Foreman, diary entries of August $8,12,1863$, Stephen Foreman Collection, WHC.

${ }^{66}$ Stand Watie, Principal Chief of the Cherokees, to His Excellency the Governor of the Creek Nation, August 9, 1863, volume XXII, series, I, Official Records, 1105-1106.

${ }^{67}$ Ibid.

${ }^{68}$ Baird, ed., A Creek Warrior, 63-64.

${ }^{69}$ Ibid., 64.

${ }^{70}$ Ibid.

${ }^{71}$ Interviews of Jim Tomm, 91:329-331, Bell Haney Labor Airington 1:338, I-PP; Stephen Foreman, diary entry of August 26, 1863, Stephen Foreman Collection, WHC.

${ }^{72}$ Interview of Ella Coody Robinson 77:117, I-PP.

${ }^{73}$ Stephen Foreman, diary entry of September 5, 1863, Stephen Foreman Collection, WHC.

74 Baird, ed., A Creek Warrior, 112-113. 
${ }^{75}$ Ibid., 65-69; Report of Major General James G. Blunt, August 27, 1863, volume XXII, series I, Official Records, 597-598.

${ }^{76}$ Rampp and Rampp, The Civil War in Indian Territory, 32-34.

${ }^{77}$ Maxey to Colonel s. S. Scott, August 23, 1864, Samuel Bell Maxey Collection, Gilcrease Institute.

${ }^{78}$ Ibid.; Arrell Morgan Gibson, The Chickasaws (Norman: University of Oklahoma Press, 1971), 238.

${ }^{79}$ Rampp and Rampp, The Civil War in Indian Territory, 85.

80 Baird, ed., A Creek Warrior, $81-82$.

${ }^{81}$ Ibid., 82-88; volume XXXIV, series I, Official Records, 1012-1013.

82 Baird, ed., A Creek Warrior, 83-84.

${ }^{83}$ Ibid. , $85-88$.

${ }^{84}$ Rampp and Rampp, The Civil war in Indian Territory, 90.

${ }^{85}$ Ibid., 104-106; Report of Captain E. A. Barker, September 20, 1864, part I, volume XLI, series I, Official Records, 771-772.

${ }^{86}$ Baird, ed., A Creek Warrior, 95-96.

${ }^{87}$ Rampp and Rampp, The Civil War in Indian Territory, 106.

${ }^{88}$ Ibid., 106-112; Baird, ed., A Creek Warrior, 99-101. 
${ }^{89}$ Baird, ed., A Creek Warrior, 101-103.

90 Ibid.

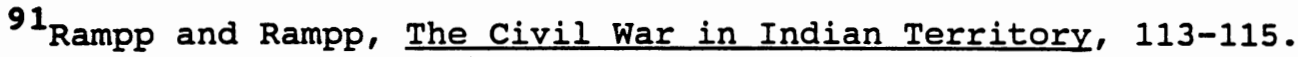

92 Baird, ed., A Creek Warrior, 102-104.

93 Maxey to Matilda Maxey, October 12, 1864, Samuel Bell Maxey Collection; interview of Ella Coody Robinson, 77:118, I-PP.

94 Rampp and Rampp, The Civil War in Indian Territory, 115-116; Maxey to Choctaw Governor Peter Pitchlyn, January 10, 1865, file 16, box 4, Peter Pitchlyn Collection, wHC.

95 Barnett to Watie, March 3, 1865, Cherokee Nation Papers, Phillips Collection, WHC.

96 Baird, ed., A Creek Warrior, 108, 111.

97 Ibid. , 111-114.

98 Ibid., 109, 121, 123; Mary Alice Robertson, "Incidents of the Civil War," box 1, 82-86, Alice Robertson Papers, OHS Archives; Debo, The Road to Disappearance, 163; Indian Journal (Eufaula and Muskogee, Creek Nation), May 1, 1878.

99 Debo, The Road to Disappearance, 173-175.

100 Statement of I. B. Luce, September 6, 1884, VI-18, Grayson Family Collection, wHC. 
${ }^{101}$ Debo, The Road to Disappearance, 174.

${ }^{102}$ Ibid., 177; Baird, ed., A Creek Warrior, 122.

${ }^{103}$ Watie to the Governor of the Creek Nation, August 9, 1863, volume XXII, series I, Official Records, 1105-1106. 
CHAPTER IV

"INDIAN CAPITAL AND INDIAN BRAINS"

\begin{abstract}
Fortunately for the resilient Creeks, they did not know that their "golden age" was behind them and that circumstances and events would conspire to prevent their reaching pre-war heights. For Confederate veteran George Washington Grayson the closing years of the 1860 s and the decade of the 1870s, as for the Creek Nation, was a time of rebuilding.
\end{abstract} He married, founded a family, started several business enterprises, and put his education to the service of the Creek Nation. He witnessed and participated in the numerous changes, some good and some bad, encroaching white civilization brought to the nation. He identified himself with the progressive faction of the Creeks, but he did so with preservation of Indian land and sovereignty as his ultimate aim.

Creek refugees and soldiers returned to the Creek Nation warily and slowly at the end of the war. The veterans knew well the devastation they left behind them on raid after raid and the bitter enemies they made among their own people. How would they treat each other? How would the victorious. Federal Government treat them? How would they live until they could again raise crops? 1

Ex-soldiers in the Indian Territory simply disbanded once the war was over and drifted away to look for friends and family. Grayson rode back to the old homeplace near North Fork Town with his brothers Sam and 
Pilot. They planned to make the place habitable again that summer before returning to the Red River Valley to escort their mother, Malone, and Louisa home. By day they worked furiously clearing brush from the overgrown fields, planting a crop, putting up fences, and repairing the house. By night they slept lightly, aware that prowling wolves and panthers were not the only predators in the land. The formerly lawabiding Creek Nation, its government and law-enforcement machinery still in disarray, was a comfortable environment for all kinds of desperate characters. Eventually the Graysons accomplished enough to bring the rest of the family home. ${ }^{2}$

Other Creeks also returned but not necessarily to their pre-war residences. Former Creek slaves, now freedmen, understood that they were to be given the lands at Three Forks, lands the wealthy mixed-blood Creek families once claimed. Many congregated there just after the war and stayed even after they realized they were not to receive the land. The settlement that developed there eventually became Muskogee and the site of Union Agency, after 1874 the single office serving all Five Civilized Tribes. With the exception of the Perryman family, the former mixed-blood plantation owners refused to live near the freedmen and moved to the vicinity of North Fork Town, an area once inhabited by the Upper Creeks. These Upper Creeks then moved still further west into the rough hills of the Cross Timbers. Grayson's neighbors now included his former McIntosh commanders and kinsmen. ${ }^{3}$

Grayson did not long remain on the family farm but left to clerk in various general stores in North Fork Town as the old settlement stirred to life once more. He was a salesman for the firm of Butler and Cox 
when George W. Stidham bought the enterprise. This association with Stidham had a profound affect on Grayson's life and career. 4

George W. Stidham, born in the old Creek Nation in 1817, was the son of a Hichita mother and a white father. Though he spoke only Muskogee until he was eighteen and always thought more clearly in that language, he was well-educated and fluent in English. Before the Civil War he was a well-to-do slaveowner, rancher, and merchant with trading posts at the Old Creek Agency and near present-day Okmulgee, Oklahoma. He frequently acted as interpreter in Creek-American negotiations, represented Hichita Town on the National Council for several terms, and was serving as a judge in the new constitutional government at the time Grayson first worked for him. Stidham's dark, seemingly full-blood face and erect, nattily-dressed figure were a familiar sight in washington, D.C.; he made at least fifteen visits there as national delegate. 5 The war dealt harshly with Stidham, one of the pro-Confederate leaders. When hostilities began he moved his family and forty slaves to Hopkins County, Texas, and purchased six thousand acres near present-day Texarkanna. But he lost the deeds in the course of the war, and emancipation freed his slaves. He returned to the Creek Nation with enough twenty-dollar gold pieces to freight several wagonloads of goods to his new North Fork Town general store. Stidham's daughter Georgeanna soon caught the attention of his new salesman. 6

Usually called "Annie," she was the daughter of Stidham's fourth wife, Ariadna Carr, one of the beautiful twin daughters of half-Irish Paddy Carr. Annie was born in 1849 at Sodom. At six her parents sent her to the neighborhood school, and at eight she made the two-day wagon 
journey to boarding school at Van Buren, Arkansas. The next year she transferred to Mrs. Smith's Female Seminary at Fayetteville. A bright, popular child, she studied music and German and enjoyed school. 7

But then the easy life ended with the family's exile in Texas. On the Stidhams' return to the Creek Nation, they felt fortunate to live in a weather-proof, mud-chinked log cabin. Stidham tanned leather and pegged together their shoes. Annie knitted all the stockings, spun and wove cloth, and braided cornshucks and wheatstraw into hats. She and her sister cooked for the family, and, as no mills operated for some time, laboriously ground all their cornmeal by hand. With the return of better times, Annie traveled with her father on his official visits to Washington. She was a guest at the last White House reception of President Andrew Johnson and stood in the rain to see U. S. Grant inaugurated in March 1869. Annie and George Washington Grayson were already engaged at the time, and she returned eagerly to "the beautiful Indian Territory." 8

Marriage to Annie Stidham offered a number of benefits to an ambitious young man. Her father was an established and influential member of the Creek government, and he was a leader of the progressive faction with whom Grayson identified. Stidham lost much in the war, but he was recovering financially and could perhaps help the young couple begin their own life together. Related to several prominent Creek and Cherokee families, Annie further knit Grayson into the mixed-blood elite of the Indian Territory. If Grayson at sixteen had felt too diffident and awkward to move in such circles, he had at twenty-six gained the 
maturity and self-confidence to propose to Annie. Besides, the war had been a great leveler. ${ }^{9}$

But if there were positive, practical aspects in such a marriage, they were less important to Grayson than Annie herself.Theirs was a genuine love match. She referred to him as her "Brave Warrior"10 and took great pride and pleasure in his accomplishments. He admired the "quiet, unobtrusive and uncomplaining" assistance she gave her stepmother in caring for the Stidham home and children. Forty years later he still considered her "the most handsome young lady I have ever seen." Grayson professed a "never-dying attachment and love" 11 for Annie in a marriage that lasted fifty-one years. Thomas B. Ruble, Grayson's old teacher at Asbury, performed their marriage ceremony on July 29, 1869--the only date besides his birth Grayson recorded in his autobiography--in a simple ceremony at the stidham cabin. "We could not put on any style," Annie remembered, because the times were still so hard. "But we were as happy as if we had been married in a mansion."12 Times remained hard for a number of years. The Graysons stayed for a while in North Fork Town, looking after Stidham's business while he made yet another trip to Washington. On his return they moved to Jennie Grayson's farm until a local property came on the market. There being no banking facilities in the Creek Nation, Grayson borrowed five hundred dollars from his great-uncle Watt Grayson to buy some cattle and hogs and a double log cabin on about twenty acres. This cabin served until Grayson could build a new house nearby. Because lumber was still expensive and scarce, he cut the trees himself and hauled them to Daniel $\mathrm{N}$. McIntosh's saw mill for finishing. The new house, two rooms with a long 
porch on the east side and a detached kitchen, boasted a wall-papered ceiling and a chimney of finished stones, the best home for miles around. There the first of their nine children, daughters orlena (1870), Mabel (1872), and Annette (1874), were born. ${ }^{13}$

Watt Grayson also furnished the capital for the business enterprise that became Grayson Brothers Mercantile. Sam Grayson first persuaded his older brother to join him as a salesman in Gray Eagle scales's general store in town. Then in the summer of 1875, the two borrowed enough money to buy out the elderly Scales.: With Watt's son Edmond they went into business for themselves and later hired their brother Pilot as a clerk. In January 1878 Edmond, perhaps more an employee than a genuine partner, was killed by a lighthorseman in a drunken brawl, so that the business devolved on the remaining partners. ${ }^{14}$ Grayson Brothers was a typical Indian Territory general store, offering seed, harness, farm machinery, and groceries in addition to "Traveler's supplies, Prints, Hosiery, Boots, Shoes, Hats, Caps, and all the etceteras requisite to a First Class Western Business House." 15 Grayson Brothers was also one of the first businesses in the new town of Eufaula. In early 1870s the Missouri, Kansas, and Texas Railroad, familiarly known as the "Katy," extended its line across the Creek Nation along the route of the old Texas Road. Railroad officials designated several spots as depots, and new white-style market towns such as Oktaha, Checotah, Bond Switch (Onapa), and Eufaula grew up at these sites. The track passed just west of North Fork Town on the higher ground above the river valleys. Several local merchants--the Grayson brothers, George W. Stidham, Gray Eagle Scales, D. B. Whitlow, 
and Joseph McDermott Coody--raised one thousand dollars to build a depot west of the old settlement. They named the spot "Eufaula" in remembrance of the old Eastern homeland. ${ }^{16}$ (See Figure 4.)

Railroads were a mixed blessing to the Indian Territory. They brought the benefits of easy access to markets within the territory and without. The Grayson brothers frequently traveled to Kansas City, st. Louis, Chicago, and Texas to restock their general store in Eufaula. This cheap form of transportation also expanded the possibilities of exploitation of Creek natural resources, particularly the coal seams evident near the new town of Henryetta. 17

At the same time, railroad construction brought an influx of legitimate white laborers as well as the gamblers, prostitutes, and bootleggers who catered to them. The railroad lines violated the limits of their rights-of-way, illegally appropriated Creek timber, and discriminated against Indian Territory shippers by charging them higher rates than those in neighboring Kansas. Moreover, they constantly lobbied Congress for the opening of the Indian Territory and the dissolution of the Indian governments. As a businessman and a Creek, Grayson must have understood the ramifications of the coming of the railroad, yet his active participation in securing a depot for Eufaula demonstrated that he hoped to profit from this technology. ${ }^{18}$

Consequently, he and Sam were among those businessmen who relocated along either side of the track in the pattern typical of the railroad town. W. F. Crabtree built the first building; D. B. Whitlow opened the first trading house. ${ }^{19}$ William Bertram, a white man and an intruder of dubious reputation, established the Eufaula House ("a sort of hotel"), 20 
Figure 4. The Creek Nation about 1880 . 


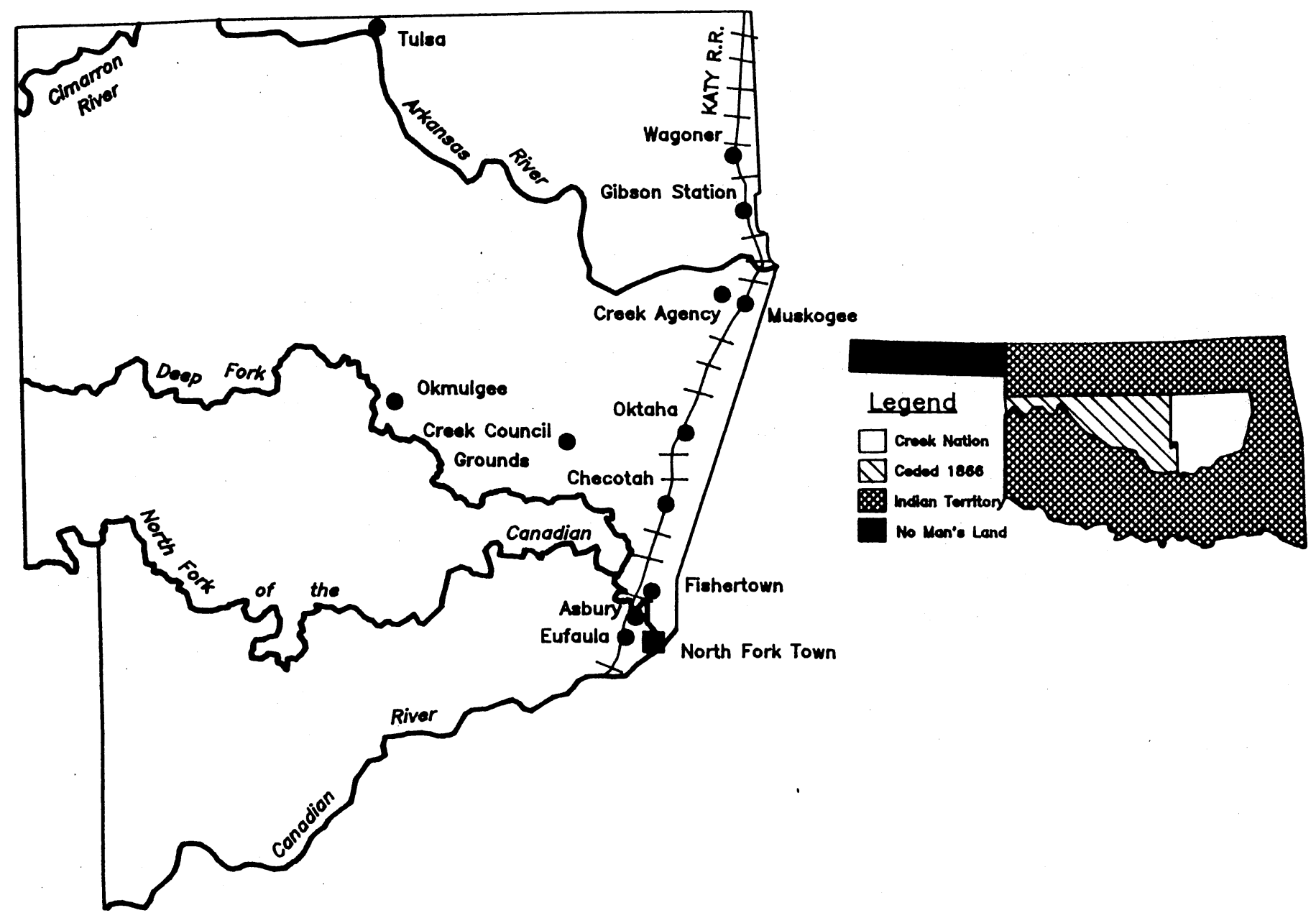


a bakery, and a harness shop near the depot. In 1874 and 1875 Grayson Brothers, George W. Stidham, and W. B. Crabtree moved over from North Fork Town. The area was still forested, and the businessmen cleared lots for their buildings out the blackjack and persimmon groves. stidham once shot a buck from the door of his half-finished store. ${ }^{21}$ Stidham and the Grayson brothers hired William Gage Fryer, a white contractor, to replace their original frame buildings with native stone store buildings. Merchants W. F. Crabtree and Stidham also operated cotton gins and a grist mill in the infant town. Within three years Eufaula boasted a wagonmaker, three carpenters, two physicians, a transplanted twenty-year old Masonic lodge with forty members, and twelve Creek Baptist churches within a twelve mile radius of the town. Only one mile from the new depot, Asbury Manual Labor School, severely damaged during the war, reopened. The businessmen also moved their residences over to Eufaula so that the little town soon occupied several acres at the base of Chintz Mountain. But as Eufaula flourished, North Fork Town dwindled into a ghost town with only a few stone foundations remaining among the weeds. 22

Eufaula's city fathers were proud of their enterprise and looked forward to continued growth with typical booster enthusiasm. Eufaula lay midway on the thousand-mile stretch of track from St. Louis to Galveston. In time they hoped projected railroad lines would connect them more directly with the Atlantic and Pacific coasts. Meanwhile, Eufaula served as the market center for a considerable hinterland rich in furs, timber, minerals, and farmlands. Merchants in outlying settlements used Eufaula as a supply and shipping point. White immi- 
grants constantly rolled through, their unoiled wheels screeching. Texas cattle herds so large they sometimes took two days to pass moved north up the Texas Road toward Eastern packing houses. Immigrants and cowboys both stopped off in Eufaula to trade in Creek-owned businesses. Grayson, no less than the other founders, predicted great things for Eufaula. Even though its three hundred inhabitants made it the largest town in the area, such amenities as bathtubs and flowerbeds as yet were scarce. In wet weather mud was hub-deep in the wide, unpaved main street; in dry weather clouds of dust swirled in the wind. ${ }^{23}$

Grayson, too, planned to move his family to the new town; but circumstances forced them into the new house on Jefferson Avenue before they were quite ready. The preceding year had been very difficult. The spring of 1875 followed a winter so hard the plowhorses died, forcing Creeks to plant their crops with hoes. Then grasshoppers and chinch bugs devoured the new growth. Grayson Brothers freighted in bushels of potatoes to feed hungry Creeks. 24

Then in October a spell of hot weather seemed to set off such a deadly round of sickness that they prayed for a norther. Jennie Grayson, who lived with her oldest son, diligently nursed the sick of the neighborhood, including her Aunt Leah, the wife of Chilly McIntosh. Leah and her husband died two weeks apart. Exhausted, Jennie caught the sickness, as did Annette, the Graysons' youngest child. She died only a few days before Jennie, to whom Grayson was devoted, died also. Early in March 1876 the first Grayson son, Walter Clarence, was born. One week later a fire destroyed the Grayson home, forcing the family to move to the new house in Eufaula. 25 
The new Grayson residence stood on the south side of Jefferson Avenue in what amounted to a Grayson family compound. Eventually Sam built a house across the street, and Grayson built substantial houses for his youngest daughters on either side of his own home. Grayson's was a one-story frame structure, modest compared to some of the later merchants' homes in Eufaula. Besides the main house, there was a detached kitchen, a guesthouse, and a small building containing Grayson's library. At the rear stood a stable and henhouse with a large kitchen garden. Grayson enjoyed overseeing its cultivation. He also gave much time and thought to planting trees and shrubs so that something bloomed at every season of the year. ${ }^{26}$

On the corner of the Grayson compound nearest the track was the Grayson schoolhouse. The one-room frame building served as a subscription school for the town's children and as a church and community center as necessary. Each morning the children brought a bucket to the Grayson house for drinking water. Only six of the Grayson children lived to attend school. Daisy (born 1879) and Anna (1891) died before their second birthdays. Besides Lena, Mabel, and Walter, those who survived into adolescence were Washington, Eloise (1880), and Tsianina (1885). 27

Despite his personal losses, Grayson the businessman prospered. In 1877 Grayson Brothers added on to their store building and by 1878 were operating a cotton gin in competition with Crabtree's. Cotton production was increasingly important to the Eufaula area: As of January 1, 1878 Eufaula merchants had shipped out 352 bales. Grayson Brothers alone by the end of February had shipped 144 bales. Their first gin ran on mule power, turning out three or four bales in a good day. Each bale 
sold for about sixty dollars. By January 1880 Grayson Brothers had

installed a twenty-horse-power engine to run the gin. ${ }^{28}$

They also went into the livestock business, the natural outgrowth of merchandizing in the Creek Nation. Merchants such as Grayson Brothers did much of their business on credit. Cash was scarce and the reputation of most Creeks for honesty and integrity made them good risks. Payment of debts came in the form of furs, skins, corn, other produce, and livestock. As shipping the one or two steers or hogs taken in trade was not economical, Creek Nation merchants began holding livestock in fenced pastures. When enough accumulated, the merchants conducted a roundup, drove their animals to Eufaula, and shipped them out by rail. It was only a short step from this expediency to dealing in livestock. In March 1878 Sam Grayson shipped sixty hogs, driven in from Little River. In June Grayson Brothers shipped sixty-three head of cattle. The next month they shipped two cars of livestock. Most of these animals went to packing houses at st. Louis or beyond. ${ }^{29}$

Eventually Grayson went into ranching partnerships with other creek citizens. Most prominent among his partners was Joseph M. Perryman, a future chief of the Creek Nation. But his longest-term partnership was with Hugh Henry. Henry was, like Grayson, a mixed-blood Creek and a Confederate veteran. Henry's background, though, was that of a cowboy and buffalo hunter; he had often trailed herds up the Texas Road from San Antonio to St. Louis and had a tough reputation. About 1878 he became a partner in Grayson Brothers' livestock operation and continued the association for about thirteen years. Henry fenced a large pasture on Coal Creek near present-day Henryetta, Oklahoma. There he ran 
thousands of cattle and hundreds of horses wearing Grayson's brand, a shield with by a horizontal bar. 30

Ranching was not Grayson's only agricultural interest. He also kept land under cultivation by a tenant farmer. In fact, Grayson in the 1870 s saw agriculture as a means for improving Creek life and reforming Creek politics. In a speech he delivered at a barbecue at J. M. Perryman's in July 1879, Grayson described agriculture as providing an honorable, moral, and disciplined way of life. Unfortunately, he believed, while many Muskogees were farmers, few were good farmers. Recalling that ancient Muskogees used social gatherings for educational purposes, Grayson called for the formation of farmers' associations at which they could discuss the best farming techniques. Using these meetings for self-education and as a power base, they could then demand Council support for prizes and premiums at agricultural fairs and exhibits. They could exert enough political influence to replace reactionary Council members who did not know potatoes from turnips and were equally ignorant of handling national finances. ${ }^{31}$ In a conclusion reminiscent of the Farmers' Alliance meetings even then gathering force in neighboring Kansas and Texas, Grayson stated, "We have had enough of law and political scheming, and what we now want is men who are willing to work for the direct benefit of the poor, the weak, the widows and the orphans." 32

A number of Creeks agreed with Grayson that agricultural fairs and exhibits could aid progress not only of Creeks but of other less civilized Indians as well. By the late 1870 s the Indian International Fair held annually at Muskogee became an institution. Here, usually in 
September or October, came members of the Five Civilized Tribes as well as a growing number of "blanket Indians" from the western frontier. 33

In 1880 Union Agent John Q. Tufts agreed with Grayson that the fair was so valuable an activity the Federal Government should provide subsistence for the western Indians who came. He noted:

Here the wild Indians meet other tribes of the Territory--they mingle with, and learn the habits, manners, customs, and laws of their more civilized brethren, and adopt them--and observe the different grades of civilization, besides they observe all the various kinds of grains, vegetables, fruits, and domestic animals raised by the other tribes, and are stimulated and encouraged to go and do likewise. I know of no greater civilizer than their annual meeting at the Indian International Fair. ${ }^{34}$

In spite of his own conviction that the fair was a means toward Indian progress, Grayson did not deeply involve himself in the supporting organization. In 1881 he was a candidate for vice-president of the Creek Nation chapter of the Indian Agricultural Society and Fair Association, but he gathered only one vote in the February election. Rather, the busy Grayson directed his energies toward a tool of progress he viewed as even more important, the Indian Journal newspaper. ${ }^{35}$

Originally published at Muskogee by Cherokee mixed-blood William Penn Ross, the Indian Journal suffered a disastrous fire on Christmas Eve 1876 that threatened to put the infant publication out of business. But in late April 1877 a joint stock company composed entirely of Indians reorganized the enterprise and moved it to Eufaula. Ross did not wish to relocate, so Myron P. Roberts, a white man, replaced him as editor. Sam Grayson acted as treasurer while a committee composed of George W. Stidham, W. F. Crabtree, and Washington Grayson supervised the publication. 36 
From the beginning this committee insisted that the journal was an Indian institution, concerned less with making a profit than with protecting Indian interests. Their motto, "we seek to enlighten," reflected a dual purpose. Many whites, they believed, perceived the inhabitants of the Indian Territory in terms of "wigwams, robes, feathers, and vermillion." Too often this misperception led to such iniquitous inaccuracies, even in the halls of Congress, as "there are no good Indians but dead ones." The Indian Journal stockholders believed that if Indians were to defend their rights and lands, they must dispel "this cloud of ignorance" and present the Indian majority as the lawabiding, settled, agricultural people they really were. ${ }^{37}$

At the same time, the publishers hoped to inform and educate the Indian public on current issues to enable them to fend off attacks on their sovereignty. Toward the Indian nations the committee stressed impartiality and unity: They hoped their readers would not regard the paper as "Creek" even though it was chartered by the Creek Nation and served as the official organ of the national government. Rather, they strove to "understand the actual interests of the whole Indian people of the Territory." 38

Six months later Chief Ward Coachman echoed these sentiments. "It is absolutely necessary for the Indian race in order to protect their interests, and make known their rights, to have some medium through which to express themselves to the thinking and reading portion of the citizens of the United States." 39 He proposed that the Creek Council use the journal to publish their laws and that they subsidize subscriptions for each of the tribal towns. Unfortunately, this last measure 
proved ineffective as many copies were never delivered; those that were, were useless to illiterate Creeks. 40

Over the next three decades stockholders and editors came and went, and the journal moved back and forth between Eufaula and Muskogee. But Grayson's association with the Indian Journal, as nearly as may be determined, was constant and close. Sometimes his name was on the masthead as associate editor; for many years he was the president of the Indian Journal Printing Company, which also did job printing for the public and the national government. Whatever his capacitý, people in the Creek Nation knew it reflected his views even though its editors insisted their printed opinions were their own. ${ }^{41}$

In content the paper was very similar to other country newspapers of the day. It carried national and international news with many items reprinted from major eastern newspapers. There were serials, sermons, agricultural advice, and educational items. A personal column detailed the social events of Eufaula and surrounding communities. Illustrated advertisements showed ladies the latest fashions and directed farmers to merchants selling seed and hardware. In addition, the journal carried news about Indians, whether it concerned the theft of horses on the Kiowa-Comanche reservation, Creek missionary work at Wichita Agency, or the visit of Spotted Tail's Dakotas to the territory. Always its perspective was Indian. 42

Because many Creeks were literate only in Muskogee, the journal also published articles in that language. For some months Grayson contributed the "Creek Corner," a column in Muskogee; and he continued for several years to include advertisements for Grayson Brothers and 
public announcements in Muskogee. Anne Eliza Worcester Robertson's diligently translated hymns appeared in the journal for the benefit of Creek Christians. Each October the journal published the proceedings of the Creek National Council and the speeches of the principal chiefs of the other civilized tribes. Dispatches and reports from the delegates of the Five Civilized Tribes also appeared in the journal, so that Indians knew the various Indian-related bills Congress considered each session. 43

Fourteen years after its inception as an Indian institution, the Indian Journal was still "a paper published in the interest of the Indians."44 Unfortunately, it was never a monetarily profitable venture, which probably accounted for the turnover in stockholders. But Grayson never lost confidence in the journal or its concept. In February 1890 he told a stockholder, "We have had a hard time and indeed it is not much easier now." Yet he was optimistic. "I feel a double interest in this enterprise because it is being run by Indian capital and Indian brains." 45

While his business enterprises consumed much of Grayson's time in the post-war years, his involvement in Creek national affairs, especially in the 1870s, were equally demanding. If James Grayson had hoped that his sons would someday attain positions of honor and trust in their national government, Washington and sam certainly fulfilled that ambition. Sam held several national posts while Washington never completely divorced himself from Creek politics from the end of the Civil War to his death in 1920.46 
Reestablishing their national government was one of the first concerns of both factions of the Creek people as they returned to their country in 1865 and 1866. In February 1867, their old council house having been destroyed during the war, they met in a grove of blackjack oaks on the south side of the Deep Fork River near Red Stick Landing. Grayson served as secretary to the convention at which they agreed to reunite and form a single government under a new constitution and a single principal chief. By casting individual ballots instead of simply forming a line behind the candidate of their choice, the traditional way of voting, they elected Samuel Checote principal chief; the second chief was Sands (Oktarharsars Harjo), Opothleyahola's successor as leader of the Loyal Creeks. The new constitution established an upper House of Kings and a lower House of Warriors with the representatives chosen on the basis of town membership. 47

By this time Creeks numbered forty-four towns with their freedmen divided among three exclusively black towns. On the first Tuesday in October this National Council met to make laws for the nation. The nation was divided into six judicial districts, with the six judges making up the Supreme Court. George W. Stidham and Walter Grayson were among the first judges. The lighthorse company bore responsibility for keeping the peace and enforcing Creek criminal law. The ex-Confederate faction of the tribe and the more-acculturated oversaw this renovation of the national government, a proceeding that the traditionalists and Loyal Creeks regarded as suspicious but for the time being tolerable. 48 In 1867 the Creeks also a needed new national capitol. The blackjack grove was too far from supplies and at least thirty-five miles from 
the nearest postoffice. Moreover, the Creek population had shifted in the post-war years to center along okmulgee Creek. The Council consequently chose a site more centrally located, and at the suggestion of Hotulke Emarthlar called it by the historically significant name, "Okmulgee." W. S. Brown, a Yuchee, contracted to build the new council house. He directed groups of Creek workmen who felled trees, squared the logs, hauled them to the site (now Capitol square in okmulgee, Oklahoma), raised the walls, and split clapboards for the roof. The completed capitol was a large two-story building with a dogtrot below, a gallery above, and rock chimneys at either end. It served for the next ten years. 49

Grayson soon found a place in this new constitutional government. Newly-elected Principal Chief Samuel Checote had served as a colonel in the Confederate Creek regiments and was a member of Grayson's own Tiger clan. These factors may have contributed to Grayson's appointment as secretary to the council that reconciled the factions. Because several of the national officials did not speak English or were illiterate, the position of secretary carried considerable importance. Though he received no pay for his services to the war-bankrupt Creek national government, the officials promised him a salary when finances permitted. In the meantime, they claimed his time and labor on the grounds that the nation financed his education. Grayson served in this capacity, alternating with Pleasant Porter and Joseph M. Perryman, for about two years before being elected National Treasurer in October 1869.50

The position of National Treasurer was no sinecure. The Federal Government resumed annuity payments in 1867. From this primary source 
of revenue the treasurer paid out the salaries of national employees and officials as well as the expenses of running the government. He also issued licenses to non-citizen mechanics and laborers who came to work in the Creek Nation and kept a list of all such permits. Grayson received a salary and a percentage of the permits fees. 51

As treasurer Grayson disbursed national monies through warrants authorized by the Creek National Council. In the absence of any Creek currency and because of the scarcity of American money in the impoverished Indian Territory, these warrants circulated as a substitute. Usually sellers accepted them at a fraction of their face value, the size of the fraction depending on the current indebtedness of the nation and the imminence of the next Federal payment. 52

Periodically the Federal Government delivered other special payments as well, frequently as much as forty years overdue. On these occasions, Creek claimants and their heirs converged in a holiday mood on the site of the payment. Army troopers escorted wagons bearing heavy boxes of silver coin from Fort Smith to the Creek Agency. The agent then distributed it through the treasurer. Sometimes each person received only a few dollars by the time the heirs of a claimant divided his share. And always awaiting the Creek recipients as they stepped away from the payment table were the local merchants, sitting at tables of their own, collecting debts owed. 53

Grayson found the job sometimes dangerous as well as onerous. Shortly after assuming the office the agent summoned him to the Creek Agency to accept a payment of $\$ 100,000$, the first installment on the $\$ 1,836,830.41$ the Federal Government allowed the Loyal Creeks for 
property losses during the Civil War. Grayson rode alone to the agency at the fledgling settlement of Muskogee. He was well aware of hostile and speculative stares as he rode through a milling crowd near the agency. In spite of the reconciliation of 1867 , serious issues still divided the nation between the Loyal, conservative Creeks, rallying around Sands, and the constitutional party of Chief Checote. The rebellious Sands faction was threatening violence. Grayson feared they would waylay him on his return to Okmulgee. 54

Colonel Timothy Barnett confirmed Grayson's fears and privately advised him to gather a bodyguard, leave during the coming night, and take the payment back to Okmulgee by some back path. Grayson quietly followed his advice. He located a lighthorseman, Johnson Kennard, in the crowd and asked for his escort back to okmulgee. That night they slipped out of Muskogee and, once out of sight of the settlement, hurried across the prairie until they felt it was safe to rest. Leaving Kennard on guard, Grayson bedded down at the base of a tree with his head pillowed on his money-laden saddle bags. By noon they next day they were safely in okmulgee handing over the funds to Chief Checote. 55 Many years later Grayson pondered his utter faith in Johnson Kennard; it never entered his head that the man might rob him himself. He concluded:

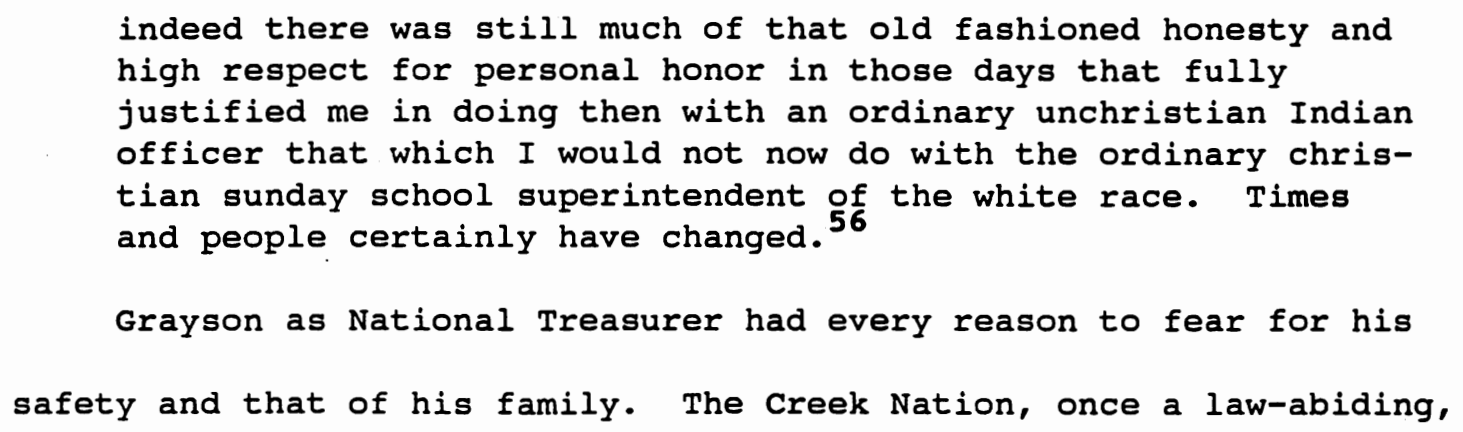


secure place to live, never rid itself of the drifters and desperados of the war years. Indians and freedmen became outlaws in the atmosphere of violence and instability that existed while the Creek government struggled to cope with post-war factionalism. Indian lighthorsemen and court systems tried to cope with this troublesome element, but lawbreakers had only to slip over the border into a neighboring nation to elude pursuing officers. Consequently, outlaws infested the Indian nations. Several, including the notorious Belle starr, made their headquarters a short distance east of Eufaula at Younger's Bend. She was perhaps one of the gang that invaded Uncle Watt Grayson's home, tortured the old man and his wife, and robbed him of $\$ 32,000$ in gold in November 1873.57

Grayson, then, had some qualms about keeping national funds in his home, especially while the family still lived in the country. One frigid winter night he and Annie woke to the sound of quiet hoofbeats approaching their door over the ice-crusted snow. His mind went instantly to the several thousand dollars in his keeping. Quickly he slid out of bed, got his gun, and raked ashes over the fire to hide his movements. Much to his relief, a few minutes later he realized that the sounds outside were those of livestock coming to lick the salt-laden clay chinking of the cabin walls. 58

These particular fears of robbery ended when the Graysons moved into town. Ironically, thieves struck sometime later, probably in October 1877. The National Council had presented him with a small iron safe in which he kept national funds and documents. One night a burglar entered the store and took more than $\$ 1,200$ out of the safe. Grayson at once reported the theft to the Council, which promptly resolved that he 
was responsible for repaying the money. Until August 1878 Grayson denied he had been negligent and refused to repay the money. Then Grayson finally conceded responsibility for the amount but, not having it at hand, could not pay it. The matter slipped until some years later when Albert Pike McKellop persuaded the Supreme Court to allow him to bring suit against Grayson for recovery. The supreme Court upheld Grayson's defense, but the incident and McKellop's suit still rankled years later. 59

Even without such incidents, dealing with Creek finances was no easy matter. While the more progressive businessmen in the Creek government understood the management of money and national credit, many of the full-bloods did not. Some Creek officials casually signed warrants and trusted the untrustworthy, especially the growing number of white opportunists in the nation. As a result, Creek finances were usually chaotic and the government in debt. 60 Just before he finished his second term as treasurer, Grayson commented publicly, "many of the members [of the Council] are good enough men otherwise, but have no more ideas of government than the Bedouins of the plains of Arabia."61

Grayson's frustration with the conservatives was never enough to make him abandon creek politics. In fact, at the same time he was serving as National Treasurer, he was also filling two other public posts. In December 1875 the National Council designated Grayson, his brother Sam, Joseph M. Perryman, and Charles S. Smith the Board of Education of the Creek Nation. They examined applicants for teachers' certificates in higher education in the fields of arithmetic, English composition and grammar, United States history, natural philosophy, 
geography, and penmanship. More important was Grayson's appointment as a Creek representative to the Okmulgee Convention. This honor provided him important first-hand experience in working in international diplomacy and in Indian-Federal relations. It also underlined Indian unity as a potent weapon in fending off white attacks on Indian sovereignty. 62 The Creeks had a tradition of diplomacy that long predated their first contacts with Europeans and underpinned the old Creek confederacy. Once in the Indian Territory, creeks continued to meet and exchange ideas with representatives of other tribes, frequently traveling far to the western frontier to smoke the pipe of peace, to exchange messages of good will, and to extend advice to those less experienced than they in dealing with the whites. They took a fraternal attitude toward the "blanket Indians," who admired what the Creeks had been able to achieve. In fact, in 1855 some bands of the fierce Comanches asked the Creeks to intercede for them with the Federal Government, that they might learn as the Creeks had how to build houses and farm. ${ }^{63}$

At the beginning of the war, the pro-Confederate Creeks joined with the other civilized tribes in creating a Grand Council or confederated government for the Indian Territory. Even in exile in the Red River Valley, the Confederate creeks continued to attend meetings of the Grand Council. And at war's end, an intertribal conference at Camp Napoleon on the Washita River sought to expand this confederated government. There representatives of all the Five Civilized Tribes and of the Caddoes, Osages, Comanches, Lipans, Kiowas, Arapahoes, and Cheyennes agreed to pursue peaceful solutions to their mutual problems and to unite against further white aggression. 64 
Strangely enough, such an effort to create a consolidated government for the Indian Territory coincided with Federal Reconstruction plans for the Indians. One of the stipulations forced on all the former Confederate allies in the Reconstruction treaties was acceptance in principle of a unified Indian territorial government. Congress appropriated money to pay tribal delegates to attend a territorial convention. But if the Federal Government saw these conferences as a way ultimately to undermine the independence and sovereignty of the individual Indian nations, its vision was quite different from that of the Indian participants. They were well aware of the growing influence of the railroad corporations in Washington, the agitation for the opening of the Indian Territory for white settlement, and the number of territorial bills with that aim introduced each session of Congress. Although wary and reluctant to attend the proposed Federally-supervised conventions, they hoped to protect their interests and control the amount of damage a territorial form of government might inflict. 65 Subsequently, Grayson was one of eleven Creek delegates, most of them progressive mixed-bloods, chosen to attend the convention that met at their own capitol. The number included old hands such as George w. Stidham as well as the younger generation: Pleasant Porter; Joseph M., Legus, and Sanford Perryman; John R. Moore; and Grayson. This was not Grayson's first diplomatic experience. As early as 1867 he had acted as clerk when Chilly McIntosh, John Jumper of the Seminoles, Jesse Chisholm, and representatives of the Caddoes signed an agreement. But appointment to this delegation carried much more prestige and responsibility. 66 
The meeting at the end of September 1870 was the first of the series of intertribal conventions known as the Okmulgee Conventions. Superintendent Enoch Hoag presided over delegations of Creeks, Cherokees, Seminoles, Ottawas, Eastern Shawnees, Quapaws, Senecas, Wyandottes, Confederated Peorias, Sacs and Foxes, Great and Little Osages, and Absentee Shawnees. The Choctaws, fearing the results of the convention, refused to attend and only one Chickasaw came. Nevertheless, the forty delegates included some of the most prominent men in the Indian Territory. Stand Watie, who had in 1863 warned the chiefs of the other civilized nations that they must stand together or fall separately, attended to represent the Cherokees. 67

The delegates created seven committees ranging from international relations to agriculture and education. Grayson's assignment was to the committee governing transaction of business during council sessions. Each committee took on a specific task or report. Perhaps that of the committee on relations with the United States was the most indicative of the Indian perspective and aim. The delegates ordered this committee to draw up a memorial to the President calling on him to uphold the treaties of 1866, prevent Congress from creating any territorial government except that of the General Council, prevent any attempt to extinguish Indian title to lands in the territory, and deny access to the territory to any other railroad than those already chartered. The General Council further resolved to transmit its actions to the Plains Tribes and invite them to send delegates to the next session. ${ }^{68}$

Because several of the committees needed time to prepare their assigned reports, the council adjourned for until December 1870 . 
Generally the same delegates attended, but this time the Chickasaws and Choctaws came as well out of fear that they might be forced to accept commitments taken in their absence. One of the council's first actions was to assign ten men, one of them Grayson, to devise a permanent organization for the convention. But he eventually resigned as Creek delegate to serve as permanent secretary to the okmulgee Conventions. 69 The major result of this second session was the production of the Okmulgee Constitution. It created a federal union patterned after that of the United States with an elected governor, a bicameral legislature, and a court system. It would go into effect once two-thirds of the voters of the Indian Territory ratified it. One historian has written that at the time these voters, particularly among the Five Civilized Tribes, were divided into three factions: a radical minority wanted the territory opened to white settlement, an ultra-conservative minority who wanted no change at all, and the majority who favored passage of the Okmulgee Constitution. ${ }^{70}$

In the end a combination of fear of what this territorial government might portend and Federal tampering prevented its adoption. The Creeks ratified the constitution at once: They, too, were apprehensive but hoped to control the future from within this territorial union. The Choctaws and several of the smaller tribes also ratified the constitution. But the Cherokees and Chickasaws rejected it, the latter on the grounds it favored the more populous tribes. As the constitution passed through the Federal bureaucracy, various officials tried to amend it to give the Federal Government more control over the proposed territorial government. These changes combined with an outcry in the white press 
against continued Indian self-government assured the constitution's defeat. A revised version introduced in 1875 received only Creek support. 71

In spite of their rejection of the Okmulgee Constitution, the Indians made valuable gains from the conventions. The sessions fostered a strong sense of Indian unity which after 1871 included the beleaguered Plains tribes. In that year the Kiowas, Comanches, Cheyennes, and Arapahoes sent representatives to confer with the delegates of the Five Civilized Tribes at the Creek Council House. The initial committee reports on agriculture and education gave them information on their current status and pointed them toward future goals while emphasizing the benefits of these elements of culture. Their delegates, including Grayson, learned to work together and used the conventions as a forum from which to deliver strong memorials to Congress and the white public on Indian rights. 72

By 1875 the Federal Government grew disillusioned with the conventions and pessimistic about achieving its own ends. In the spring of 1878 an inquiry as to whether Congress should fund another session of the General Council elicited a negative response from Union Agent S. W. Marston. Little good would come, he stated, of sessions devoted to how best to oppose imposition of territorial government and American citizenship. Instead the delegates would concentrate on strengthening the ties that bound them and encouraging the more primitive to imitate the example of the more civilized. ${ }^{73}$

Nevertheless, the tribes of the territory continued to meet regularly at their own expense for the next two decades. From the beginning 
they published the journals of their conventions, and they realized the impact of their polished and politically sophisticated protests on the small but growing number of friends of the Indian. At the 1875 session the delegates had agreed to go one step further and publish their own territorial newspaper dedicated to Indian rights. It was this journal, originally published in Muskogee, which nearly foundered before its rebirth in 1877 as the Indian Journal. ${ }^{74}$

Through all these events Grayson remained an active participant. He oversaw the business affairs of the okmulgee Convention as permanent secretary for ten years while periodically serving as a Creek delegate. 75 often the multilingual nature of the conventions demanded he also act as an interpreter. These various roles contributed to his standing in the territory, particularly among the "blanket tribes." Years later Grayson noted:

My complexion and person having so much the appearance of the white man that I could speak the Indian as I did appeared striking to the wild Indians who attended these councils. The fact that $I$ was Indian and spoke the language and was also secretary of this great Indian body appointed by the secretary of the Interior at Washington, impressed the simple representatives of some of those tribes with the belief that I must be a person of very considerable importance and fully entitled to their confidence. Whenever I met any of them either in Washington or elsewhere as I often did years afterwards, they would in perfect confidence state to me their business and ask my advice. 76

Such recognition extended beyond the territory. A description of

the Creek delegates that appeared in the St. Louis Globe and several

Western newspapers in 1873 gushingly described the secretary of the convention as:

emphatically the financial man of the Creek Nation--perfectly honest, competent to discharge any duty, he stands very high in the estimation of the people. Capt. Grayson possesses 
that...ability which knowing the right dares to defend it; perfectly regardless of fear, he works for the interest of his people untiringly, but not unrewarded. No man is more popular in the Nation.

There was even a hint that Grayson's popularity might take him much higher. In July 1875 The Vindicator of Atoka, Choctaw Nation, reported, "Capt. G. W. Grayson is a candidate for principal chief of the Creeks. Crazy Turtle [Lochar Harjo], who can't run fast, is one of his competitors, while samuel Checota, of third term aspirations, is another."78 The jocular tone of the lines and the fact they were written by H. F. Buckner, minister and family friend of the Graysons, suggests that the writer was teasing rather than making a serious observation about political events. Either way, the chieftaincy eluded Grayson for another forty years.

In the meantime, Grayson found his niche in the Creek Nation as a businessman and diplomat. His energetic pursuit of business opportunities and his education set him among the elite of the Indian Territory and apart from the Indian majority. Yet Creek inclusiveness and the dynamic nature of Creek society historically tolerated such differences. Creek leaders of the 1870s, unlike those reactionary officials of the immediate post-removal years, understood the changing nature of the times and the threats against their national sovereignty. They valued Grayson's abilities and called on him to use his understanding of both the white and Creek worlds in the service of the nation. Grayson recognized that "fortune and circumstances have placed me in some respects in advance of some of my fellow countrymen."79 But his comments in the rejuvenated Indian Journal made it clear that he believed what he had achieved was not only possible for most Indians but 
necessary if they were to maintain their rights against an intolerant and aggressive white race that prided itself on its civilization. Setting up a constitutional government, building Eufaula, making use of modern technology, and graduating an ever-growing number of Creek children from national and American schools appeared to white observers as acculturation and a major step toward assimilation. But for Grayson and like-minded progressive Creeks, these achievements made them no less Creek. They lost some traditions, but they gained new strengths-particularly literacy. Meanwhile, Creeks demonstrated their equality with whites as human beings and prepared for the struggle to maintain their identity as a sovereign nation. Their methods were progressive, but their goals were conservative.

Grayson, then, saw himself not as alienated from his fellow Creeks but as a member of their vanguard. His education, business skills, experience with the okmulgee Conventions, and wide acquaintance with Indian Territory inhabitants and problems prepared him to defend his nation as a diplomat just as he had defended it as a warrior. And by the late 1870s, it was clear that the legal and political assault on the Indian Territory was gathering force on its borders as well as in the chambers of Congress. 
NOTES

1W. David Baird, ed., A Creek Warrior for the Confederacy: The Autobiography of Chief G. W. Grayson (Norman: University of Oklahoma Press, 1988), 116.

2Ibid., 121-123.

${ }^{3}$ Angie Debo, The Road to Disappearance: A History of the Creek Indians (Norman: University of Oklahoma Press, 1941; 1984), 170-171, 213.

4 Baird, ed., A Creek Warrior, 126-127.

${ }^{5}$ Georgeanna Stidham Grayson, untitled manuscript (property of Mrs. Mildred Fuller Ewens, Eufaula, Oklahoma); "Stidham Family," Vertical File, Oklahoma Historical Society Library, Oklahoma City, Oklahoma.

${ }^{6}$ Grayson was briefly engaged to Molsie James, daughter of a wealthy and prominent Chickasaw, at the end of the war. But responsibility for his family and his own lack of fortune caused him to break the engagement. Grayson later commented that genuine love was also lacking in the relationship. Baird, ed., A Creek Warrior, 117-119; Georgeanna Stidham Grayson, untitled manuscript.

7 Ibid.

8 Ibid.

9Annie's sister Celestia, for example, married Evarts Foreman, the son of mixed-blood Cherokee missionary Stephen Foreman. "Stidham Family," Vertical File, OHS Library; Baird, ed., A Creek Warrior, 127-129.

${ }^{10}$ Georgeanna Stidham Grayson, untitled manuscript.

11 Baird, ed., A Creek Warrior, 127-129. 
${ }^{12}$ Georgeanna Stidham Grayson, untitled manuscript.

13 Baird, ed., A Creek Warrior, 130-131.

14 Ibid., 141; National Auditor Records, Third Quarter Reports, 1875, Creek Indian Memorial Association Records, OHS Archives; List of Traders in Creek Nation--Indian, 1879-849, reel 872, microfilm 234, Letters Received, office of Indian Affairs, Department of the Interior, National Archives, Washington, D.C. (hereafter cited as OIA LR); Indian Journal (Eufaula and Muskogee, Creek Nation), January 9, 1878.

${ }^{15}$ Indian Journal (Eufaula and Muskogee, Creek Nation), August 10, 1876.

${ }^{16}$ Ibid., April 26, 1877; interview of Richard Young Audd 3:294, "Indian-Pioneer Papers," microfiche, Works Progress Administration Project s-149, Western History Collection, University of Oklahoma, Norman, Oklahoma (hereafter cited as I-PP).

${ }^{17}$ Indian Journal (Eufaula and Muskogee, Creek Nation), January 16, March 6, 1878; Debo, The Road to Disappearance, 367.

18Debo, The Road to Disappearance, 197-199; Acting Commissioner of Indian Affairs A. Buschard to T. J. Portis, General Solicitor, Missouri Pacific Railroad, June 18, 1888, LB 174-106, Office of Indian Affairs, Land Division, NA, Washington, D.C.

${ }^{19}$ Indian Journal (Eufaula and Muskogee, Creek Nation), April 26, 1877 .

20 Union Agent S. W. Marston to Commissioner of Indian Affairs E. A. Hayt, May 30, 1878, reel 870, microfilm 234, reel 870, OIA LR; Indian Journal (Eufaula and Muskogee, Creek Nation), April 26, 1877. 
21"G. W. Grayson", box 6, Grant Foreman Collection, OHS Archives.

${ }^{22}$ Interview of Richard Young Audd 3:292, interview of Minnie Fryer Finigan 30:40, I-PP; Indian Journal (Eufaula and Muskogee, Creek Nation), April 26, 1877.

23 Indian Journal (Eufaula and Muskogee, Creek Nation), April 27, 1877; "North Fork Town," box 13, Grant Foreman Collection, OHS Archives; interview of W. E. Baker, 4:269-270, Joe M. Grayson, 35:435-436, R. B. Buford 13:82-83, I-PP.

24 Baird, ed., A Creek Warrior, 141-143; The Vindicator (Atoka and New Boggy, Choctaw Nation), April 30, 1875.

${ }^{25}$ The Vindicator (Atoka and New Boggy, Choctaw Nation), October 13, 1875; Baird, ed., A Creek Warrior, 141-143.

${ }^{26}$ Mildred Fuller Ewens, interview by author, October 12, 1989, Eufaula, Oklahoma.

27 "Creek Schools," box 6, Grant Foreman Collection, OHS Archives.

${ }^{28}$ Indian Journal (Eufaula and Muskogee, Creek Nation), January 23, February 13, 1878; January 29, 1880; "G. W. Grayson," box 6, Grant Foreman Collection, OHS Archives.

${ }^{29}$ Interview of Earnest Archer, 3:6-7, interview of Charles Augustus Berryhill, 7:415-416, Andrew Jackson Berryhill, 7:396, I-PP; Indian Journal (Eufaula and Muskogee, Creek Nation), March 13, June 19, July 17, 1878 .

30 Henryetta was, of course, named for Hugh Henry. "Henryetta-Hugh Henry," Vertical File, Henryetta Public Library, Henryetta, Oklahoma; 
interview of Texanner Guinn, 36:369, John Likowski, 54:86-104, I-PP; Indian Journal (Eufaula and Muskogee, Creek Nation), October 19, 1882.

31 Mildred Fuller Ewens, interview by the author, October 12, 1989; Indian Journal (Eufaula and Muskogee, Creek Nation), August 7, 1879.

32 Indian Journal (Eufaula and Muskogee, Creek Nation), August 7, 1879 .

33 Angie Debo in The Road to Disappearance, in view. of the mixedblood directorship judged these fairs to be a "white man's project," 232; Department of the Interior, Office of Indian Affairs, Letters Received, Union Agent John Q. Tufts to Commissioner of Indian Affairs R. E. Trowbridge, July $31,1880$.

34 Tufts to Commissioner of Indian Affairs R. E. Trowbridge, July 31, 1880, 1880-967, reel 877, microfilm 234, OIA LR.

${ }^{35}$ Indian Journal (Eufaula and Muskogee, Creek Nation), February 17, 1881.

${ }^{36}$ Ibid., May 3, 1877. An undated list of stockholders (probably compiled before 1878) also included William Robinson, David Benson, David Barnett, James McHenry, J. M. Perryman, N. B. Moore, John R. Moore, D. M. Hodge, Ward Coachman, F. B. Severs, Thomas Kannard, Thom Adams, John F. Simpson, J. MCD. Coody, Samuuel Grayson, D. B. Whitlow, Edmon Grayson, William Fisher, David Carr, and Pleasant Porter. 34100, Creek National Records, microfilm, reel 40, OHS Archives (hereafter cited as CRN).

${ }^{37}$ Ibid.

${ }^{38}$ Ibid.

39"To the National Council, M. N.," November 2, 1877, 34080, CRN 40. 
${ }^{40}$ Ibid.; G. W. Stidham to Chief Samuel Checote, April 23, 1881, 34085, CRN 40 .

41 Indian Journal (Eufaula and Muskogee, Creek Nation), November 14, 1889, June 8, 1895; Muskogee (Creek Nation) Phoenix, November 28, 1889.

42 Indian Journal, (Eufaula and Muskogee, Creek Nation), May 3, 1877.

43Ibid.; see, for example, the issues of November 9, 1876; May 8, 1877; February 20, 1878; April 8, 1880.

44 Ibid., November 14, 1889.

${ }^{45}$ Grayson to N. B. Moore, February 21, 1890, Special Collections, McFarlin Library, Tulsa University, Tulsa, Oklahoma.

${ }^{46}$ Sam Grayson, for example, served as clerk of the House of Kings for several years, a delegate to Washington, and National Treasurer in the 1890s. The Vindicator (New Boggy, Choctaw Nation), May 31, 1873; Debo, The Road to Disappearance, 354-359.

47 Interview of Samuel J. Haynes. 40:315-316, I-PP; Debo, The Road to Disappearance, 179-181.

48 Debo, The Road to Disappearance, 181-183.

${ }^{49}$ Interview of Samuel J. Haynes, 40:320, 331-333, I-PP.

${ }^{50}$ Grayson signed the reunification document as secretary on February 11, 1867. "Samuel Checote's Book of Records," CRN 9, 35-36; interview of Emma Bell Checote Canard, 15:265, I-PP; Daniel F. Littlefield, Jr., and James W. Parins, A Bibliography of Native American Writers, 1772-1924, Native American Bibliography Series, number 2 (Metuchen, N. J.: The Scarecrow Press, 1981), 222; Baird, ed., A Creek Warrior, 126.

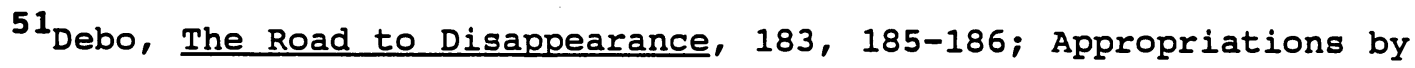


the National Council of 1878, "Samuel Checote's Book of Records," 90-92, CRN 9.

52Debo, The Road to Disappearance, 203-204; Annual Address of Samuel Checote to the National Council, october 4, 1881, microfilm 1070, reel 55, Reports of Inspection of the Field Jurisdictions of the office of Indian Affairs, 1873-1900, Records of the Bureau of Indian Affairs, Record Group 75, NA.

${ }^{53}$ For example, the Federal Government finally paid off the Creek Orphan Claim, which originated at the time of removal, fifty years later in 1882. Only about 25 of the 573 orphans were still living. The silver coins alone weighed 1,875 pounds. Indian Journal (Eufaula and Muskogee, Creek Nation), January 25, 1883; Debo, The Road to Disappearance, 265268; "North Fork Town," box 13, Grant Foreman Collection, OHS Archives; interview of Will Robison, 77:251-252, I-PP.

54Debo, The Road to Disappearance, 375-376; Baird, ed., A Creek Warrior, $132-134$.

55 Baird, ed., A Creek Warrior, 132-135.

56 Ibid., 136 .

${ }^{57}$ Other notorious outlaws who made their headquarters at Younger's Bend included the Daltons, the Youngers, the Starrs, and Frank and Jesse James. Debo, The Road to Disappearance, 229-231, 253; interview of Richard Young Audd, 3:296, I-PP; Glenn Shirley, Law West of Ft. Smith: A History of Frontier Justice in the Indian Territory, 1834-1896 (New York: Henry Hold and Company, 1957, 86-91, 314; Contract between G. W. Grayson and J. B. Luce, July 10, 1876, OIA LR. 
58 Baird, ed., A Creek Warrior, 138-140; interview of Eloise Grayson Smock, $85: 370$, I-PP.

${ }^{59}$ Baird, ed., A Creek Warrior, 144-146; Principal Chief Ward Coachman to G. W. Grayson, February 14, 1878, Coachman to the Houses of Kings and Warriors, August 1, 1878, CRN 21.

60 Debo, The Road to Disappearance, 244-245.

${ }^{61}$ Indian Journal (Eufaula and Muskogee, Creek Nation), August 7, 1879.

62 "Samuel Checote's Book of Records," 69-70, CRN 9.

63 Debo, The Road to Disappearance, 136-138; Superintendent C. W. Dean to Commissioner of Indian Affairs G. W. Manypenny, September 13, 1855, AR CIA 1855, 121.

64 Debo, The Road to Disappearance, 144-145, 164-165.

65Ibid., 205-207; "Journal of the General Council of the Indian Territory," Chronicles of Oklahoma 3 (April, 1925):32-34.

66 "Journal of the General council of the Indian Territory," 36 ; "Samuel Cheocote's Book of Records," 39-40, CRN 9.

${ }^{67}$ Debo, The Road to Disappearance, 205-206.

${ }^{68}$ Records of the General Council of the Indian Territory, September 27-30, 1870, microfilm 856, reel 31, Records of the Central Superintendency of Indian Affairs, 1813-1878, Records of the Bureau of Indian Affairs, Record Group 75, NA.

${ }^{69}$ Ibid., December 6, 1870; Debo, The Road to Disappearance, 205-206. 70"Okmulgee Constitution," Chronicles of Oklahoma 3 (September, 
1925):218-228; Ohland Morton, "Reconstruction in the Creek Nation," Chronicles of Oklahoma 9 (June, 1931):176.

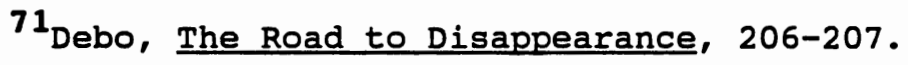

72 Ibid., 209-210.

${ }^{73}$ Marston to Commissioner of Indian Affairs E. A. Hayt, March 22, 1878, microfilm 234, reel 870, OIA LR.

${ }^{74}$ See, for example, 30845, 30847, 30851, 30862, and 30869, CRN 37; "Journal of the General Council," 35; Debo, The Road to Disappearance, 210.

${ }^{75}$ Union Agent G. W. Ingalls to Superintendent Enoch Hoag, December 7, 1875, microfilm 856, reel 37, OIA LR; Commission of G. W. Grayson as delegate to the International Council, Grayson Family Papers, V-26, WHC

76 Baird, ed., A Creek Warrior, 147-148.

${ }^{77}$ The Vindicator (Atoka and New Boggy, Choctaw Nation), May 31, 1873. ${ }^{78}$ Ibid., July $3,1875$.

${ }^{79}$ G. W. Grayson, "An Apology," Indian Journal (Eufaula and Muskogee, Creek Nation), July 7, 1881. 


\section{CHAPTER V}

\section{"ALI THAT IS LEFT FOR OUR CHILDREN"}

For George Washington Grayson the private man, the decade of the 1880s was a mellow time of continuing success in business, a growing family, and a happy home. But for Grayson the creek politician and diplomat, the decade was a defensive struggle, involving turmoil within the Creek government and two major territorial crises. During that decade Grayson continued his political identification with the progressive faction of the Creek Nation and supported its attempts to preserve the national sovereignty and land-base. But by the end of the decade he had reason to doubt whether progressive Creeks did know best how to preserve their nation. 1

No other aspect of Creek life received more credit as evidence of progress toward white-style civilization than the creation of a constitutional government in 1867. Grayson never forgot that Creeks governed themselves satisfactorily for centuries under their old customs, which provided "peace and good order" as evidenced by the "strength and happiness of the people." But when the white men arrived, they arrogantly concluded that "the Indian's policy and religion were defective and inadequate." The Creeks, Grayson believed, were "lashed" into accepting new ways. A realist, he believed the Creeks could have done nothing else and acknowledged that many had "long since learned to 
adopt, love and respect many of the principles of government and religion that have been so industriously and persistently taught them by... diplomatic and Christian missionaries." 2

Grayson played an active role in this constitutional government, first as National Treasurer and then, beginning in 1883 , as a member of the House of Warriors for his town, Coweta. But it was his concurrent role as a Creek delegate to the international councils and to Congress that placed him in the front ranks of the defense of the Creek Nation. Grayson was already established as an international delegate through his work in the okmulgee Conventions when a territorial crisis threatened not only the Creek Nation but all of the Indian Territory beginning in the late $1870 s^{3}$

In common with the Indian majority Grayson opposed any change in the status of the Indian Territory, but he knew that the pressure to open it to homesteaders was growing in the late 1870s. The demand for formal territorialization, destruction of the individual national governments, and substitution of allotment in severalty for the traditional communal landholding system was gaining strength in Congress and in the American press. Powerful railroad lobbies were pressing hard for changes in the status of the territory as a means of gaining the generous subsidies of public lands--currently Indian lands--granted them under Federal charter. 4 Hostile neighbors in surrounding states condemned the Indian Territory as a barrier to the progress of the whole region. One speaker called it "a grand fenced zoological garden" 5 for savages too lazy to work. This, of course, was exactly the impression Grayson and his fellow stockholders in the Indian Journal sought to 
disprove.

Ironically, one of Grayson's own race provided a justification for a full-scale homesteader invasion of the heart of the Indian Territory. Elias C. Boudinot, a mixed-blood Cherokee and a lobbyist for the railroad interests, advocated the allotment of Indian land and the opening of the territory to white settlement. ${ }^{6}$ These views caused Grayson to castigate him as "the Benedict Arnold of the Indian race."7 In July 1878 Boudinot, Grayson, and Governor Allen Wright of the Choctaws addressed a banquet audience at Fort Scott, Kansas. Grayson and Wright refuted Boudinot's views and his claim to speak as a representative of the Indian Territory. They denied even 1 percent of the Indian citizens agreed with his sentiments. 8

But six months later Boudinot published an article in the Chicago Times that identified fourteen million acres in central Indian Territory as public domain. This area lay west of the present Creek Nation and was a part of the lands extorted from the Five Civilized Tribes in their Reconstruction treaties for the future settlement of other Indians or freedmen. These lands were as yet unoccupied. Therefore, Boudinot reasoned these "Unassigned Lands" were public domain open for homesteading. Boudinot's article received wide-spread attention in neighboring states, and several "boomer" colonies organized to settle the Unassigned Lands, also called "Oklahoma." 9 (See Figure 5.)

Recognizing the danger inherent in such a claim, the leaders of the Five Civilized Tribes reacted quickly in the spring of 1880 . They warned the western-most tribes to keep watch for intruders, and they reminded the Federal Government of its treaty obligations to protect 
Figure 5. The Post-Civil War Creek Nation and Unassigned Lands. 
their borders. The danger to them all reinforced the unification trend begun during the Civil War, and their international correspondence and public statements emphasized the need to maintain a united defense of their common interests. In March 1880 Chief Checote informed Grayson that he was to attend an international council designed specifically to deal with this latest threat. In the next few months the threat crystallized around the person of David L. Payne. ${ }^{10}$

Payne, the most famous of the "boomers," was a peculiar combination of hero and huckster, a charismatic martyr to his followers and a petty but persistent lawbreaker to Federal authorities. Historians differed as to what motivated Payne to form his Oklahoma Colony and storm repeatedly into the forbidden heart of the Indian Territory, but the Indians had little doubt. Grayson's Indian Journal looked no further into such ventures than the Katy Railroad. ${ }^{11}$ The editor of the cherokee Advocate declared, "He is but the tool in the hands of others, who see in the scheme a chance for a big steal." 12

Payne, accepting Boudinot's premise that the Unassigned Lands were public domain, gathered an army of settlers. They took up stations along the Kansas border pending a full-scale invasion. Payne knew that the punishment for the first act of intrusion was simply expulsion from the territory. The second offense drew a one-thousand dollar fine as well. Intending to put the issue before the courts, Payne invaded the Indian Territory in April 1880, was arrested and expelled, and returned in July to be arrested for the second time. Subsequently, Federal troops delivered the intruder to Fort Smith, Arkansas, for trial before Federal Judge Isaac C. Parker in March 1881. ${ }^{13}$ 
Grayson and the delegates to the international council of the Five Civilized Tribes convened at Eufaula in October 1880. They easily saw through Payne's strategy. He was, they believed, only a front man for the railroad interests that would spare no expense in assuring his courtroom defense. Should the Federal court find in his favor, the barriers against non-citizens would fall. ${ }^{14}$ Above all else, they stressed the need for Indian unity. Grayson signed for the Creeks the joint proclamation that called on "all true Indians to rally with us in our common defense"15. The council created a Committee of Prosecution-Grayson, D. W. C. Duncan for the Cherokees, B. F. Overton for the Chickasaws, James Thompson for the Choctaws, and Thomas Cloud for the Seminoles--to attend the Payne trial. To pay its expenses, the council assessed each nation according to its ability to pay. ${ }^{16}$

On December 15 the Committee of Prosecution discussed the situation. Grayson spoke for them all when he described the coming trial as "a crisis in our affairs of a very grave character."17 Because a great deal of highly inflammatory publicity was appearing in territorial and state newspapers, they decided their first move was to assess the boomers themselves. Consequently, on December 17 Grayson and three committeemen traveled incognito to Caldwell, Kansas, a border town near which the boomers had set up winter quarters. The boomers soon correctly identified them as Indians; even so, they welcomed the four into their camp. 18

Grayson was not impressed with what he saw there. Instead of the several hundred eager settlers newspaper accounts led them to expect, they saw about seventy-five "hungry, half-clad backwoods white men, than 
whom a more worthless horde [could] hardly be found in all the balance of christendem [ $\underline{\underline{s i c}] . " 19}$ Duncan agreed with Grayson's assessment. He described them as "the most degraded and ignorant specimens of human society--deluded and shamefully imposed upon by Payne and other leaders."20 These potential settlers owned about thirty-two "pretty good lumber wagons with shabby teams," and there were no women and children among them. They summed up Payne as of little account, a man who spent his time in the local saloons and other "places of dissipation" drumming up support and rallying the faltering. These boomers were "evidently the dregs of the white population of Kansas and adjoining states." 21 They lacked the numbers, the resources, and the equipment necessary to develop a frontier; from such as these the Indians had little to fear. 22

Still, the committee recognized a real danger in "a wicked superior intelligence" that "might if possible so warp the structure of statutes and treaties as to ostensibly favor this Oklahoma movement." Should even one intruder succeed in bending the law, Grayson concluded, "it would [be] sufficient to legalize the overwhelming of our entire Territory by just such a population as those."23 Nevertheless, before the committee left the boomer camp, they tried to discourage the boomers. What was said and by whom can no longer be determined, but it was acrimonious enough that Grayson warned, "We are doing all we can to prevent the opening of the country, and you had just as well go home, for we have bought, and can buy, your Congressmen like so many sheep and cattle." 24 Moreover, they threatened to raise an army of five thousand to drive out the boomers should the Federal Government allow the colony 
to enter Oklahoma. 25

The final threat titillated border newspapers for several weeks. Indian warfare was no light matter on the Kansas frontier. Some editors reminded their readers that the Indian Territory was home to as many as eighteen thousand Civil War veterans, skilled and experienced guerrilla warriors. Once across the Kansas border, they would find little to stop them if they wanted to go all the way to Topeka! ${ }^{26}$ Grayson's Indian Journal reported in July that three hundred Indians were organizing, stockpiling weapons, and planning to drive out the intruders if Federal troops failed to stop the invasion. Scouting parties were even then combing the Cimarron and Canadian river valleys, looking for intruders. "On every hand," editor Roberts declared, "a determination is expressed to fight for their rights." 27

In spite of such speculation and Grayson's warning, Indian Territory citizens had no intention of making war on the boomers. Six months after the confrontation near Caldwell, Grayson publicly dismissed talk of armed resistance as editorial bombast. ${ }^{28}$ Nor could the usually financially-strapped Indian governments afford to outbid the railroad corporations for Congressional loyalties. Grayson in threatening to raise an army against the invasion probably either lost his temper or was playing on the popular imagination to achieve by fear what he could not achieve by reason.

Rather, the Indian response to the Payne threat demonstrated their progress toward constitutional forms and the rule of law. They placed their trust in the Federal court system, Federal laws, and their own treaties with the Federal Government to uphold their rights. The same 
day the Committee of Prosecution confronted the boomers, they issued a news release in which they played down the danger of Payne's boomers and directed attention toward the real fight in the courtroom in Fort Smith. 29

While the national delegates in Washington did all they could to influence Federal officials, Grayson and Duncan countered pro-boomer publicity with their own to calm Indian fears and rally American public opinion behind Indian rights. Because journalists from the Associated Press recognized a developing story on the Kansas-Indian Territory border, news of the committee's confrontation with the boomers and Grayson's warning appeared in the New York Times within twenty-four hours. The boomer-Indian conflict became national news with editors from Chicago, New York, and Philadelphia championing one side or the other. ${ }^{30}$ Cherokee Chief Dennis Wolfe Bushyhead spoke for Indians generally when he hoped that the great mass of the American public did not side with the boomers, who represented "infamous Cortez and Pizarro element of freebooters and robbers, as contra-distinguished from the honest Anglo-Saxon Race who control and dictate the policy to the nation." 31

Grayson also hoped that Judge Parker's court would favor his cause even though its seat was Fort Smith, a town, he noted, "by no means too friendly to Indians." 32 Judge Parker and the Federal prosecutor solicited statements of the Indians' views on the various treaties and land cessions involved in the case as well as their help with the prosecution during the months before the trial. The members of the Committee of Prosecution conferred with them in Fort smith. ${ }^{33}$ overton 
believed their presence would "produce a good effect among the whites who are ever ready to gobble up our lands. It will show them," he stated, "that we are united and determined to meet them on every point that they may make in that direction." 34

Grayson and the committee members were in the courtroom when the trial commenced on March 7, 1881. Duncan, a Dartmouth-trained lawyer, aided the Federal prosecutor while Elias C. Boudinot and three attorneys--one of them James M. Baker, president of the St. Louis and San Francisco Railroad--spoke for Payne. Judge Parker heard the arguments and then deferred his decision until the May court session because of the importance of the issue. That in the meantime he visited st. Louis, base of several railroad corporations, aroused suspicion in the minds of Grayson and those who were convinced Payne was their tool. Consequently, they maintained pressure to assure a decision in their favor. ${ }^{35}$ In the end, Parker decided for the Indians. He reasoned that neither Payne nor any other non-citizen had the right to homestead "Oklahoma." The Federal Government had forced the cession as a home for future Indian settlement, and it was still Indian land whether or not it had been "assigned." The boomers were non-Indians, and having no permits, were intruders in the Indian Territory, liable to arrest, expulsion, and fine--at least until the law was changed. ${ }^{36}$

For the time being, the Committee of Prosecution and Indians in general were elated. Grayson in his final report to the Creek National Council concluded, "It is pleasant to know...that in this decision of the United States Court, the Indians have become possessed on one of the strongest levers yet placed within their grasp for compelling a just 
recognition of their rights and the integrity of our whole Indian Territory." 37

Grayson's elation was short-lived, for even as he was writing his report on the successful outcome of this territorial crisis, another was developing within the Creek Nation. While the Creeks maintained unity with their neighbors and so averted a development they perceived as a territorial disaster, they found it difficult to maintain unity among their own people.

The source of the trouble lay in the resentment conservative Creeks felt toward the progressive constitutional Creek government. One historian summarized the situation by pointing out that creek progressives such as Grayson adopted constitutional government as the most effective way of squelching the white man's schemes to destroy their independence and protect their lands. In doing so, however, they excluded the conservatives, who did not understand the new system. In consequence, while some conservatives agreed with the progressives on the benefits of education, Christianity, and agriculture, they still objected to the new constitutional government. This dissatisfaction combined with traditional hostilities, Civil War bitterness, and aspirations of Creek freedmen to destabilize Creek government until 1883.38

Grayson was serving either as National Treasurer or as a member of the House of Warriors from Coweta Town during two constitutional crises in the 1870s and early 1880s. His role was more that of observer than of participant. But during the third crisis Grayson was also serving as a Creek delegate in Washington, D.C. Having recognized much earlier 
that they could expect little support from their agent, a political appointee, against a hostile Congress and bureaucracy, the Five Civilized Tribes routinely appointed their own citizens to attend each session of Congress to represent their interests. Grayson therefore acted as a lobbyist and a liaison between the Federal and Creek governments on this and many other occasions. 39

This most serious constitutional crisis occurred during Chief Samuel Checote's tumultuous third term. Conservative Creeks and freedmen rallied around Isparhechar, a full-blood, to oppose Checote's progressive constitutional government. Checote alienated even some of his own faction when he attempted to prosecute Isparhechar in late 1881 on party-inspired criminal charges, a move Grayson and George w. Stidham warned him was unwise. Isparhechar responded by arming his followers, and Checote called out the militia to maintain control. Because the hungry warriors helped themselves to unripe fruit from the orchards along their route of march, they called the rebellion the Green Peach War. 40

In December 1882, while Grayson was guarding Creek interests in Washington, Isparhechar's armed followers converged on the Creek capital from the Cherokee Nation and the western districts. Checote sent his militia under the command of General Pleasant Porter against Isparhechar. In a running fight that lasted several days, Porter pursued Isparhechar westward across the Sac and Fox lands but gave up the chase when the rebels took refuge near Wichita Agency in present-day western Oklahoma. 41 Checote appealed to Union Agent John Q. Tufts for support, but that official was slow to understand the panic of backcountry creeks 
who remembered Opothleyahola's flight in 1861 and mixed-bloods who hustled their women and children to safety in Muskogee or the Choctaw Nation. 42

Consequently, Checote instructed Grayson to request military support, in Grayson's words, "to teach these malcontented Creeks the necessity for obedience of the recognized laws of the nation." His young son Walter Clarence in tow, Grayson lobbied at the War Department until he persuaded Secretary Robert Todd Lincoln, "a stickler for the conventionalities of the ways of official business in Washington commonly called red tape, " 43 to send in Federal troops. Tufts finally arrived in the Creek Nation with fifty men to restore order and reassure the Creek population. 44

Isparhechar's insurgents returned to Fort Gibson in July 1883 under Federal protection. Grayson and delegate James Larney passed that summer in Washington, trying to persuade the Commissioner of Indian Affairs to resolve the conflict. Grayson insisted that Isparhechar was nothing more than a disappointed office-seeker using the discontent of a few full-bloods and freedmen to attempt the overthrow of the dulyelected constitutional government. Furthermore, he charged that the tardiness of the Federal officials in dealing with this crisis demonstrated a lack of concern for the very form of government the white men insisted the Creeks adopt. 45

In August 1883 Chairman Clinton B. Fiske and Secretary E. Whittlesey of the Board of Indian Commissioners arbitrated the dispute between the factions. Grayson was one of the ten-man constitutional delegation that negotiated with Isparhechar and his supporters. The 
peace settlement and amnesty they agreed on finally ended political violence if not disagreement. By backing the progressive Creeks the Federal Government further consolidated their dominance over Creek affairs. 46

Unfortunately, the following september brought a disputed national election between candidates Isparhechar, Checote, and Joseph M. Perryman. When Grayson and a committee from the council counted the votes, Perryman clearly led checote with Isparhechar a poor third. The committee dismissed returns from three towns as irregular. Isparhechar protested to the Department of the Interior, but Perryman took office as principal chief on December 5, 1883. In the meantime, Checote threw his support to Isparhechar. When the new Council convened after the first of the year, it recounted the votes and declared Isparhechar the winner. Less than two weeks after Perryman took office, then, Isparhechar was also inaugurated as principal chief. ${ }^{47}$ By this time the new Council had also elected delegates to Washington. Those chosen for 1884 were Isparhechar, Checote, David M. Hodge, and Grayson. 48

Grayson recognized the irony of the situation as well as the ominous implications. A Checote supporter since 1867, he and other progressives found the old chief's defection to Isparchechar unpalatable. Grayson attributed it to the distribution of patronage rather than any substantial issue. Isparhechar, a man he personally respected, represented a reactionary philosophy and had not won legitimately in his opinion. David M. Hodge, an educated Loyal Creek, seemed to Grayson to shift positions with every wind. Grayson was torn between his personal loyalties and his duty to the council that had elected him. 49 
For several weeks Secretary of the Interior Henry M. Teller delayed delivering a decision on the controversy. Grayson, who favored Perryman's candidacy, grew concerned that the other delegates were giving Teller the wrong impression of Perryman, depicting him as "a white man, and fifty years ahead of the people over whom he was claiming to have been elected chief." To combat this impression, Grayson telegraphed Perryman to join them in Washington. A few days later he presented Perryman, "very dark complexioned, quite as much so as a full-blood Indian, and a man of limitea education but of great good common sense, "50 to Teller, who ruled in his favor. Although Teller justified his decision by explaining that Perryman's election represented the majority opinion in the Creek Nation, Grayson attributed the favorable decision to his own strategy. 51

Perryman's election further consolidated the progressives' hold over the leadership of the creek Nation and placed Grayson very near the center of power. Grayson and Perryman collaborated in business as well as in politics and were neighbors in Eufaula. More importantly, Perryman shared Grayson's philosophy concerning the status and future of the Indian. Congratulating him later that year on securing an exhibition reservation at the New Orleans World's Fair, Perryman noted that this type of display could rectify the false impressions white Americans held regarding Indians. The exhibit would allow citizens of the territory to "bring themselves to the notice of the world that Indians are capable of receiving a higher grade of civilization." 52 still, Grayson did not consider his part in securing Perryman's election an unalloyed victory. He believed the progressive faction 
represented the aspirations and salvation of his nation, and that faction had won. But on two occasions now he had been required to relay to the Federal Government a call for help in settling purely creek disputes. Such pleas undermined the principle of self-government creek progressives so strongly advocated and conveyed the very image Grayson strove to disprove through his private and public life, that of a people too primitive to manage their own affairs. 53

Still, Grayson's effectiveness as a representative of the creek Nation apparently garnered him more elections as a Creek delegate. He went to Washington, or "the White Nation" as the Creeks called the Federal capital in their own language, each year from 1882 to 1888.54 Matters with which he dealt included the Loyal claims, the CreekSeminole boundary, problems with the railroads, and Federal obligations toward the Creek Nation. Asbury Manual Labor School burned in 1888. As a delegate Grayson petitioned the Federal Government for money to rebuild, and Eufaula Boarding school replaced his alma mater on the hillside on the south edge of Eufaula. Intrusion remained a perennial problem, and Grayson worked to staunch the seepage. Generally his instructions directed him to oppose any change in relations between the United States and the Creek Nation, allotment, the creation of any kind of territorial government without Indian consent, and the settlement of Oklahoma. 55 He was to guard "the integrity of the Indian territory with the view to holding the same indefinitely as the home of the Indian." 56 While there were probably many benefits to being a delegate, it was also a dreary and frustrating duty. Grayson attended sessions of Congress and its committees, kept abreast of the printed news, wrote 
letters to the newspapers, studied pending legislation, read past decisions on Indian affairs, and wrote memorials incorporating those decisions whenever a bill threatened Creek interests. By 1888 the delegates of the Five Civilized Tribes had developed a unified strategy and a modus operandi. Two blocks from the Capitol on Pennsylvania Avenue was a small hotel they designated "the Wigwam." Here every Wednesday night they held a council at which they smoked cigars and discussed politics, religion, and literature. They also considered the latest Congressional measures affecting Indians. Here they decided which man would appear before what committee, designed plans of defense, and determined what lines of argument to take. In that typical GildedAge parlor was one symbol to remind them who they were: On the mantle lay an ornate calumet carved from Minnesota pipestone. 57 Because the Creeks generally included among their delegates representatives of various factions and those with claims pending, the Creek delegation frequently included a full-blood or conservative who did not speak English or comprehend the workings of Washington bureaucracy. The more experienced, bilingual Grayson then acted as interpreter both of language and custom. Such was the case in 1888 when the other delegate was Isparhechar. Once at odds on constitutional issues, the two men put their differences behind them. An observer noted that they were close friends, and Grayson always accompanied Isparhechar to interpret for him. ${ }^{58}$ The cross-country railroad journeys and the long, long weeks away from home must have been even more uncomfortable for those less familiar with the white world than Grayson. He sympathized strongly with Coweta Micco, a venerable chief of Grayson's own town, who 
sickened and died in that strange city in "a little second class hotel," and was buried far from home in Washington's Congressional Cemetery. 59

But the second-class hotels and boarding houses were not for Grayson. He stayed at the prominent National Hotel or the historic Willard. He also took these opportunities to expose his children and later his grandchildren to life in the nation's capital. As Walter Clarence, Washington, and the girls grew older, they often joined him on his official visits. 60

So did Annie. More than just an adjunct to his life, Annie Grayson was his intellectual equal, as proudly Creek, and as dedicated as he to Indian rights. Grayson described her as one who "entertained a loyal affection for our people, and who is patriotic to a fault."61 For her, visits to the city included sightseeing, the theater, White House receptions, escorting the children to the annual Easter egg hunt, and social occasions with the families of Federal bureaucrats. ${ }^{62}$ But Annie also attended hearings related to Indian affairs and listened with particular sympathy when the Indians involved were those less sophisticated than the creeks. She understood just as well as her husband the powerful forces threatening to overwhelm "those dear red brethren."63

In Washington as a delegate, Grayson also took the opportunity to press his own claims. As an heir of his great uncle Watt Grayson, he represented family members trying to recover $\$ 32,000$ stolen from the old man in 1873. They based their claim on the Federal Government's failure to protect an Indian citizen from non-citizen criminals. ${ }^{64}$ As an Indian Grayson's competency to enter into contracts was automatically suspect and required Bureau of Indian Affairs approval. However, the attorneys 
involved protested,

Mr. George W. Grayson does not stand in need of any such protection. He is amply able to protect himself. He understands this claim and its proseeds [sic] as well as we do. He is as competent to write a contract as we are, and it would not be difficult to prove that in this matter he has made as good and shrewd a contract as we have. 65

When Grayson entered into a new contract with attorney J. B. Luce, Supreme Court Justice Arthur MacArthur witnessed it. 66

Gradually Grayson built up a wide number of acquaintances and a reputation as an able man experienced in dealing with whites. In 1888 Lone Wolf, a Kiowa, and Tah-bee-nanah-kah, a Comanche, came to Washington unescorted and found themselves unable to communicate with the bureaucrats. They appealed to Grayson, who probably knew Lone Wolf from the international councils. He came to the rescue and telegraphed Captain Richard H. Pratt at Carlisle Indian School in Pennsylvania to send two of his students to Washington to interpret. 67

Moses Keokuk, chief of the Sac and Fox tribe, frequently wrote Grayson during his diplomatic missions, asking that he include his people in any measures he took to protect the interests of the Creeks. The Seminoles also relied on Grayson and the Creek delegates to represent them. On one occasion an elderly Kickapoo rode more than one hundred miles to Eufaula bearing an official envelope containing a completely incomprehensible letter. Grayson's Creek and English being of little use as the old man understood neither, he was forced to send the Kickapoo home with no real clue as his need. ${ }^{68}$ More amusing was the occasion on which the Caddoes inquired whether he knew a "Frogmountain or Jackmartin" who wished to serve as their attorney. Grayson wrote 
back that he did, indeed, know former Governor James W. Throckmorton of Texas and could recommend his services. 69

Grayson enjoyed the recognition, and it probably went some way toward alleviating the frustration and foreboding he felt as he viewed at first hand the slow erosion of Indian sovereignty during the late 1880s. If Grayson truly believed in 1881 that the Payne decision left "no loophole...through which... any white or colored citizen of the United States [could] enter and occupy any portion of the Indian Territory", 70 he was proved mistaken quite soon. Weakened temporarily by Parker's ruling and Payne's sudden death in 1884, the boomer movement rallied under new leadership. Meanwhile, editorial and Congressional assaults on the territory continued even as eastern humanitarians worked actively toward allotment of communal lands in severalty as the panacea for the Indian problem. These seemingly unrelated issues, allotment and the opening of oklahoma for settlement, represented the Indians' greatest fear, that they would be submerged in an alien flood. ${ }^{71}$

In common with the great majority of Indian Territory citizens, Grayson abhorred the idea of allotment and its ramifications. He clung to the communal landholding system and regarded the alternative as one that "had pauperized thousands of people."72 Conversely, his fatherin-law George W. Stidham wrote, "We have [no tramps], we have our own farms, no taxes to pay; our papers are not filled with advertisements of lands for sale on account of delinquencies." 73

But they were aware of the addiction of both white friends and foes to the idea of allotment. In 1878 the United States Senate Committee on Territories headed by John J. Patterson visited Muskogee, Okmulgee, and 
Eufaula in the Creek Nation. Before they arrived, the contending factions healed their differences enough to present a consensus to the investigators. Mixed-bloods, full-bloods, and freedmen explained the workings of the Creek government. Grayson as National Treasurer and a prominent businessman testified before the committee. ${ }^{74}$

The investigators asked Grayson the questions they asked all the Creek witnesses: Were the Creeks advancing? Grayson confirmed that they were, particularly in agriculture. Did any Creek favor allotment? Grayson, as had every other Creek witness, responded, "I do not know a single man." 75 seven hundred and five Creeks then signed a petition which called on the Federal Government not to extend over them an alien political and social system which would "entail the degradation and destruction of the masses of our people."76 Yet when the committee returned to Washington, it reported favorably on the possibility of allotment of the communal lands. 77

Knowing that congress often demonstrated such deafness toward the Indian's opinion, Grayson grew ever more pessimistic while adhering to the principles of Creek self-government and communal land-holding. In the spring of 1885 editor R. M. Roberts of the Indian Journal suggested that it might be time to end the isolation of the Indian inherent in the reservation system by opening the territory through allotment and white settlement. Grayson refuted this in an article on "The Indian Question." Quoting the former superintendent of the census, Grayson reiterated the argument opposing allotment: Assigning the ignorant and ill-prepared individual a share of Indian land laid him open to fraud and poverty. Dispossessed, these Indians became "shifting sores upon 
the public body, " 78 turning to begging, stealing, and prostitution to support life. Grayson predicted an outbreak of violence and crime if whites were allowed to settle among the Indians. This would then provide a justification for those Texans, Missourians, and Kansans who called for a territorial government to replace those of the Indian nations. 79

Grayson believed Indians should expect the worst, for past "Indian management" had all been bad, and "Indian rights" had little meaning. He concluded bitterly,

No wonder Indians are hard to Christianize, for while teaching them to do to others as they would have others do to them, the white man has been practicing on them the philosophy of Pizarro and his priests, DeSoto, Hood, and the rest. If this be the teachings of a Christian civilization, then, shades of Tecumseh and osceola, hold back your hands a little while and the Indian will gladly die the death of a pagan, and with them and you risk their chances before that other tribunal where it is said all wrongs are righted. 80

During the January 1886 session of Congress Grayson returned to Washington as the fight against allotment moved into a critical phase. Congress was considering the Dawes (General Allotment) Bill, which proposed to allot to each Indian 160 acres of his tribal lands. Any surplus would be open for homesteading. The intent was to end both • tribalism and the protective isolation of the Indian reservation. Grayson and the other delegates turned to the new National Indian Defense Association for support. It included the former governor of Pennsylvania as well as Dr. Blundell, the President's minister. The latter incurred public criticism when he went before the senate committee to speak out against allotment, and the Creek and Seminole delegates called on him to express their appreciation of his efforts. 81 
Meanwhile, the international council convened at Eufaula attempted once again to create an Indian territorial government but found too many difficulties in the way. Instead, the council adopted a "Compact Between the Several Tribes of the Indian Territory." Among its provisions was one stating that the respective nations "solemnly pledge ourselves to each other that no nation party to this Compact shall without the consent of all the other parties cede or in any other manner alienate to the United States any part of this present Territory." 82 But in July disturbing news filtered back to the Indian Territory. With the allotment bill apparently close to passage, the Creek delegates, it was rumored, in direct contravention of the compact had broken ranks with the other Indian representatives and were secretly suggesting they would be willing to sell their remaining interest in the Unassigned Lands for the right price. ${ }^{83}$

Grayson publicly denied the rumor as a "pitiful incarnation of mendacity and pusillanimity" perpetrated by the St. Louis Globe-Democrat. That newspaper, he believed, meant to sow distrust among the Indian nations. This instance reminded him of the Indian ball game he had attended during the summer. As the players bloodied each other in their eagerness to get at the ball, one complained to a Creek elder that he was being hit unnecessarily. The old man replied that he should remember that the action was always fiercest near the ball. Grayson shrugged off criticism: "Whenever I am struck, it is perhaps a sign that the Creeks are 'nearest the ball' and trying to do their whole duty. " 84

In January 1887 he was back in Washington continuing the fight. 
With Pleasant Porter and the other delegates, he called on President Cleveland to protest, among other things, the allotment bill. Cleveland told them he would try to see their rights were protected. But the Dawes Act passed early in the year and realized one of the Indians" greatest fears. The act did not apply to the Five civilized Tribes or to the Osages. These progressive Indians understood the interplay of Congress, the Indian rights groups, and American public opinion and used their knowledge to oppose the policy effectively. But the Creeks understood the anxieties of the less sophisticated and more vulnerable "blanket Indians" and sympathized with them. 85

The process of allotting the land was necessarily slow because it involved surveying the lands, making up census rolls, adjudicating claims of tribal membership, and assigning each Indian his allotment as fairly as possible. Those Indians affected continued to protest and hope that something might yet be done. Some turned to the Creeks and the international council for mutual support and a vehicle of opposition. Grayson attended the session that met at Eufaula in June 1887. Twenty tribes sent delegates who voiced their frustration in the face of Federal intransigence. 86

Grayson asked the delegates to listen to the experiences of Chief Jake of the caddoes. When the chief visited the Commissioner of Indian Affairs to protest against allotment, that official angrily poked his finger in the elderly Indian's face and accused him of saying only what the intermarried whites and mixed-bloods told him to say. Grayson then, at the request of the western tribes, wrote a resolution that called on the Federal Government to postpone imposing this legislation on a 
"powerless and protesting people" 87 until its validity could be tested in the Federal courts. But when the commissioner received the resolution he dismissed it and the council as a meddling, trouble-making tool of the Five Civilized Tribes to whom the allotment policy did not even apply. 88

The Creeks hardly adjusted to the reality of the Dawes Act before the demands to open the Unassigned Lands escalated. The following year, 1888, marked the crumbling of international unity and the end of Creek resistance to any change in territorial status. Perhaps Grayson felt the shifting undercurrents as early as January 1888, for that month he wrote an article for the Indian Journal in which he called for an end to international bickering and recrimination. He signed it not as George W. Grayson but by his creek name, Yaha Tustunugga. ${ }^{89}$ This was unusual and perhaps was meant to remind his readers of his and their Indian identity. At about the same time he and his fellow delegate Isparhechar presented a protest to House Bill 1277, yet another attempt at territorialization and the opening of the Indian Territory to white settlement. Such action, he repeated, would do "irreparable harm to our less-civilized brothers" and loose a "human cyclone" on "a quiet and confiding people." 90

But Grayson was by now out of step with the progressive leaders of his nation, for by late 1888 a sentiment favoring some final settlement with the Federal Government over Creek claims to the Unassigned Lands was growing. At the October session of the Creek Council, Chief Legus c. Perryman announced this major change in policy: He favored selling the Unassigned Lands if the price was right. The Creeks argued that 
they had ceded their western lands in 1866 for $\$ .30$ an acre as a future home for other Indians. Now they would surrender their residual claim to the lands if the Federal Government agreed to supplement the price to $\$ 1.25$ per acre. With such negotiations pending, the choice of national delegates for 1888-1889 was especially critical. The Muskogee Phoenix suggested the Council could do no better than to send Grayson, Stidham, Isparhechar, Hotulk Emarthlar, and Pleasant Porter to negotiate the final settlement. 91

But for the first time in several years Grayson was not a member of the Creek delegation. Since spring Grayson's daughter Mabel, then about seventeen, had been ill. In August Mabel's deteriorating condition curtailed Grayson's diplomatic activities. His father-in-law, George w. stidham, still vigorous and shrewd at seventy, substituted for him in Washington until the Congressional recess. Grayson was present for at least part of that critical council session, representing coweta Town in the House of Warriors. Mabel, his favorite child, died on October 16 while the Council was still meeting; and he returned home for her funeral. 92 But another reason for his absence may have been his opposition to Perryman's policy. The Creeks kept no record of debates in their Council; however subsequent letters from Pleasant Porter to Grayson clearly counted him among the opposition. "I am sorry you are skeptic [sic]," Porter wrote. 93

The delegation that fall included Porter, David M. Hodge, Isparhechar, and Efau Emathla. Isparhechar, of course, was no fool and no political novice; but his lack of English forced him to rely on an interpreter. Efau Emathla, another full-blood, died of pneumonia on 
December 19, soon after the delegates' arrival. Hodge was a good interpreter and an experienced delegate but, in Grayson's opinion, prone to vacillation. Therefore, the real work of the delegation fell to Porter, who readily accepted the accolades later bestowed on him for his delegation's success. 94

But Porter, perhaps not so confident as he appeared, corresponded often with Grayson during those winter months, listing the benefits of such a sale and soliciting his support as a Creek leader and as a newspaper publisher. Porter argued in this private correspondence that if the Creeks did not sell their interest while they had the chance, the Federal Government might yet move the western tribes into the Unassigned Lands and end any chance of the Creeks' realizing the additional value. Relinquishing their interest immediately might gain them as much as $\$ 3,000,000.95$ The agreement signed January 19 indeed gave the Creeks $\$ 2,280,857$, a sum Porter believed would solve the Creeks' financial difficulties and allow them to educate every child in the nation. 96 The delegates immediately forwarded the agreement to the council, called into special session to consider it on January 29. Porter cajoled Grayson for his support, "You are one of its most intelligent members and leaders. I have but to say, do your duty to your country and people." He repeated an invitation for Grayson to join them in Washington and concluded with a postscript: "Explain the matter to our mutual friends. Esparhechar sends his best wishes to you. The old man has acted nobly he has a very high opinion of you and believes implicitly in you standing by our work." 97

As soon as the Council ratified the agreement, Grayson telegraphed 
the triumphant Porter. 98 Porter replied that this was a new beginning for more equity and justice in Federal treatment of the Indian. The Creeks were now in the van, leading the other Indians to "higher successes." Porter once again appealed to Grayson, "If I were in the newspaper business, I would throw off all respect to the prejudices of the past. And lead the public thought to a higher conciption [sic] of their future destiny." 99

But other Indians had doubts as to where the Creeks were leading them. As late as November 1 the Indian Arrow of Vinita, Cherokee Nation, stoutly denied that the Creek delegates would "endanger the interests and safety" of all the Five Civilized Tribes by ceding the Unassigned Lands. 100 The Choctaws' Atoka Independent also regarded a possible Creek cession before the fact as unthinkable, "a blot upon the Nation that years could not wipe away," and doubted that "men of such sound reasoning and unquestionable experience in Indian affairs as the Creek delegates, Gen. Porter and G. W. Grayson"101 would be a party to such a policy. But the strongest condemnation after the fact came from the Indian Chieftain. The writer accused, "We made a compact with the Creek nation years ago. They have broken it by selling Oklahoma without consulting us." 102

More important, though, was the immediate result of the sale. The Seminoles quickly followed the Creek lead in selling to the Federal Government their own interest in the Unassigned Lands. With "Oklahoma" now indisputably public domain, a presidential proclamation threw this area in the heart of the Indian Territory open for homesteading by means of a land run on April 22, 1889. Even that did not appease the land- 
hungry for long. Other openings of former Indian reservations occurred in 1891, 1892, 1893, 1895, 1901, and 1906. With the Oklahoma Cession the Creeks permitted the first breech in the defenses of the Indian Territory; in so doing, they made the hold of all the civilized tribes on their lands and future even more tenuous. 103

Although it is clear that Grayson opposed allotment and foresaw nothing but ruin for many Indians under that policy, little is known about Grayson's exact views on the Oklahoma Cession. Pleasant Porter's letters to him during and immediately after the negotiations strongly suggest that Grayson believed it was unwise. Moreover, support of the cession required a complete reversal of the policies he had advocated and actively pursued as a delegate during the preceding decade. Nothing in his private or public statements suggests that this was the case. Rather, his absence from washington until mid-February, after the cession passed the Creek National Council, indicates that he wished to distance himself from the negotiations. He was by no means in seclusion during these critical three months. He went on his annual hunting expedition, made a business trip to Texas, attended Federal Court in Fort Smith, and got on with his affairs--none of which demanded his exclusive presence. Porter's repeated invitations to join the delegates in washington suggest that he refused to take part in the negotiations. Political considerations may have weighed in such a decision. He had now held three elective offices in the Creek National Government and hoped to hold others (as his subsequent actions demonstrated). He may have decided to let Pleasant Porter receive whatever accolades or acrimony the cession was sure to draw. Or he may simply have found the 
cession so objectionable he would not involve himself in it until it was an accomplished fact. Only after the cession was ratified and returned to Congress in late February did he join the other Creek delegates in Washington. His goal then was, perhaps, to prevent the next step proposed, the opening of Oklahoma for homesteading; if so, Congress refused to listen to his appeals. 104

For two decades Grayson had identified himself as a progressive, one of the vanguard of the nation. He had optimistically helped found a town, published a newspaper, built a business, encouraged education, and supported constitutional government--all directed ultimately toward protecting the Creeks' landbase and right of self-government. He had confidently worked with leaders of the other nations and Creeks such as Samuel Checote, Pleasant Porter, and Legus Perryman, sure that in them lay the salvation of the Creek Nation. But by the late 1880 s his high hopes turned to pessimism and his faith to skepticism.

It became apparent that not all progressives marched at the same speed or even in the same direction. In 1882 samuel Checote forfeited his support when he sacrificed principles for patronage. In 1888 porter and Legus Perryman effected a major change in Creek policy that Grayson had fought fiercely for ten years. They favored the oklahoma Cession as a way out of Creek financial difficulties. They justified breaking the unity of the Five Civilized Tribes on the ground that the boomers, the railroad corporations, and neighboring states were demanding access to the Indian Territory. Change was inevitable, and they must accommodate it or risk losing everything. But by their actions they risked marching too far ahead of moderate and conservative Creeks at the same time 
they weakened the hold of all the nations on the their territory. No one understood this better than Grayson. The Creeks undermined their own ability to defend their interests, but the fight was not over. 
NOTES

$1_{\text {portions of this chapter were first published in an article, "Fight }}$ for Survival: Indian Response to the Boomer Movement," Chronicles of Oklahoma 67 (Spring 1989):30-51 and are reprinted here with the permission of the Oklahoma Historical Society.

2Wash Grayson and James Larney, "The Creek People," a letter to Commissioner of Indian Affairs H. Price, July 17, 1883, published in the Indian Journal (Eufaula and Muskogee, Creek Nation), July 26, 1883.

${ }^{3}$ Creek records indicate that Grayson represented coweta Town in the House of Warriors from 1883 to 1891 and may have served in 1892 and 1897 as well. W. David Baird, ed., A Creek Warrior for the Confederacy: The Autobiography of Chief G. W. Grayson, Civilization of the American Indian, volume 189 (Norman: University of Oklahoma, 1988), 146.

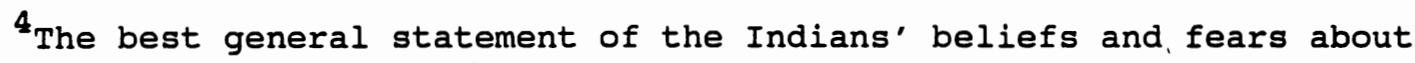
white designs on their territory and their rights may be found in the "Proceedings of the International Conference of the Tribes of the Indian Territory," Eufaula, Creek Nation, May 27, 1879, 30811-A, Creek National Records, microfilm, reel 37, Oklahoma Historical Society Archives, Oklahoma City, Oklahoma (hereafter cited as CRN).

5 St. Louis Globe Democrat, August $8,1880$.

6Angie Debo, The Road to Disappearance: A History of the Creek
} 
Indians, Civilization of the American Indian (Norman: University of Oklahoma, 1941, paperback edition, 1984), 210.

${ }^{7}$ New York Times, December $18,1880$.

8Ibid.; The Cherokee Advocate (Tahlequah, Cherokee Nation), July 13, 1878.

${ }^{9}$ Stan Hoig, The Oklahoma Land Rush of 1889 (Oklahoma City: Oklahoma Historical Society, 1984), 3.; Debo, The Road to Disappearance, 210, 240241 .

10 Even the "blanket Indians" understood the nature of the Payne crisis. Chief We-qua-ho-ka of the Sac and Fox tribe wrote to the Chief of the Creeks on May 4, 1881, "We always depend on you. Anything you will do we will agree with you. P.S. We are brothers we must be one mind." 30822, CRN 37; Creek Principal Chief Ward Coachman to Cherokee Principal Chief Charles Thompson, March 16, 1879, Correspondence and Records of the Principal Chiefs, volume 63, p. 245, CRN 21; Debo, The Road to Disappearance, 241; Grayson to Checote, March 8, 1880, 30815, CRN 37.

$11_{\text {The two primary biographies of Payne are Carl Coke Rister, Land }}$ Hunger (Norman: University of Oklahoma, 1942) and Stan Hoig, David L. Payne: The Oklahoma Boomer (Oklahoma City: Western Heritage Books, 1980). Indian Journal (Eufaula and Muskogee, Creek Nation), May 15, 1879.

${ }^{12}$ Cherokee Advocate (Tahlequah, Cherokee Nation), October 13, 1880. 
13James E. Goodwin, ed., The Federal Reporter: Cases Arqued and Determined in the Circuit and District Courts of the United States, Auqust-November, 1881, volume 8 (St. Paul: Minnesota West Publishing Company, 1881), 883-896.

${ }^{14}$ Cherokee Principal Chief Dennis Wolfe Bushyhead to Chief Samuel Checote, September 10, 1880, 30765, October 5, 1880, 30767, CRN 37 .

15"Action of the International Convention held at Eufaula...in Reference to the Prosecution of David L. Payne, "October 20, 1880, 30768, ibid.

${ }^{16}$ Ibid.

${ }^{17}$ Grayson to Chief Checote, october 22, 1880, 30769, ibid.

${ }^{18}$ Grayson to the National Council, October, 1881,30780 , ibid.; Sumner County (Kansas) Press, December 23, 1880.

${ }^{19}$ Grayson to the National Council, October, 1881, 30780, CRN 37.

${ }^{20}$ Duncan to Chief Bushyhead, December 17, 1880, F37, "Intruders" file, M943-1-13, Cherokee National Records, microfilm, OHS Archives (hereafter cited as CNR).

${ }^{21}$ Duncan, Grayson, Cloud, and Overton, "For the Advocate," Cherokee Advocate (Tahlequah, Cherokee Nation), January 5, 1881.

22 Ibid. 
${ }^{23}$ Grayson to the National Council, October, 1881, 30780, CRN 37 .

24 Sumner County (Kansas) Press, December 23, 1880.

25 Ibid.

${ }^{26}$ New York Times, December 11, 1880; Chicago Evening Journal reprinted in the Indian Journal (Eufaula and Muskogee, Creek Nation), December 23, 1880 .

27 "Trouble Ahead," Indian Journal (Eufaula and Muskogee, Creek Nation), July $15,1880$.

${ }^{28}$ Grayson, "A Talk on the White settler Question," ibid., June 2, 1881 .

29Duncan, Grayson, Cloud, and Overton, "For the Advocate"; Grayson to the National Council, October, 1881, 30780, CRN 37.

${ }^{30}$ Indian Journal (Eufaula and Muskogee, Creek Nation), November 30, 1880; W. A. Phillips to Chief Bushyhead, November 30, 1880, "Intruders," M943-1-23, box 1, F-33, Cherokee Nation Papers, Phillips Collection, Western History Collection, University of Oklahoma, Norman, Oklahoma. New York Times, December 18, 1880.

${ }^{31}$ Chief Dennis Wolfe Bushyhead, Second Inaugural Address, Indian Journal (Eufaula and Muskogee, Creek Nation), November 11, 1880.

${ }^{32}$ Grayson to the National Council, October, 1881, 30780, CRN 37. 
${ }^{33}$ Parker to Bushyhead, September 14, 1880, F20, Federal Prosecutor William H. H. Clayton to Chief Bushyhead, October 15, 1880, F25, "Intruders" file, M943-1-12, CNR.

${ }^{34}$ Overton to Bushyhead, October 29, 1880, F27, ibid.

${ }^{35}$ The Federal Reporter, 8:883-896; Rister, Land Hunger, 96; Duncan to Chief Bushyhead, March 10, 1881, F42, "Intruders" file, M943-1-13, Phillips Collection; Grayson to Chief Checote, March 17, 1881, 39772, CRN 37.

${ }^{36}$ The Federal Reporter, 8:883-898; Hoig, David L. Payne, 110.

${ }^{37}$ Grayson to the National Council, October, 1881, 30780, CRN 37. Grayson also noted that he had worked twenty-six days and spent only $\$ 179.30$ of the $\$ 500$ and carte blanche the Creek Nation had given him for the prosecution. He thriftily returned the remaining $\$ 320.70$. The creek Nation further awarded D. W. C. Duncan $\$ 400$ for his legal services in the case. Their total expenditures were $\$ 579.30$. Historian Angie Debo commented that if one considers the outrageous sums Creeks later spent on legal fees to secure their rights and dues from the Federal Government and the importance of the case, this was indeed a bargain. Debo, The Road to Disappearance, 258.

${ }^{38}$ Debo, The Road to Disappearance, 226.

${ }^{39}$ Ibid., 201-202, 213-227, 245-248. 
40 Ibid., 249, 251-253, 268-272; interview of Will H. Robison, 77:243244, "Indian-Pioneer Papers," microfiche, WHC (hereafter cited as I-PP).

${ }^{41}$ Debo, The Road to Disappearance, 272-278; J. M. Perryman to Grayson and [Legus] Perryman, December 27, 1882, Grayson Family Collection, V-2; Indian Journal (Eufaula and Muskogee, Creek Nation), December 28, 1882.

${ }^{42}$ Commission of G. W. Grayson as a delegate, October 18, 1882, Grayson Family Collection, V-34; Alice Robertson, "The Last Christmas at Tullahassee" in "The Muskogee Nation," an unpublished collection at the OHS Archives; interview of Lena Tiger Benson, 91:67, interview of Barney C. Robinson, $77: 64-65$, I-PP.

${ }^{43}$ Baird, ed. , A Creek Warrior, 156.

44. Debo, The Road to Disappearance, 275-276.

${ }^{45}$ Grayson and Larney, "The Creek People," Indian Journal (Eufaula and Muskogee, Creek Nation), July 26, 1883.

46 Debo, The Road to Disappearance, 279-280; Chief Checote to Grayson and James Larney, June 15, 1883, Grayson Family Collection, I-17.

${ }^{47}$ Reports of Election Count of October 8,1883 , october 12 and December 4, 1883, Division of Manuscripts Collection, box 1, WHC; Debo, The Road to Disappearance, 281-283.

${ }^{48}$ Commission of G. W. Grayson to serve as a delegate, approved 
October 18, 1882, Grayson Family Collection, V-34; Baird, ed., A Creek Warrior, 159.

${ }^{49}$ Baird, ed., A Creek Warrior, 158-161.

${ }^{50}$ Ibid., 161

$\mathbf{5 1}$ Teller to the Commissioner of Indian Affairs, February 27, 1884, 35506, CRN 23; Baird, ed., A Creek Warrior, 161.

52 Perryman to Grayson, July 7, 1884, VII-26, Grayson Family Collection.

53 Baird, ed., A Creek Warrior, 161-162.

${ }^{54}$ See various commissions, IV-12, IV-13, IV-15, V-6, Grayson Family Collection.

${ }^{55}$ See, for example, Grayson to Commissioner of Indian Affairs H. Price, July 12, 1884, 1884-13146, Commission of the Creek Delegates, December 1, 1885, 1885-30524, Grayson and Porter to J. D. C. Atkins, January 5, 1887, 1887-868, Porter and Grayson to Atkins, January 21, 1887, 1887-2144, Grayson and Isparhechar to Atkins, February 14, 1888, 18884348, Grayson and Isparhechar to Atkins, March 29, 1888, 1888-8392, Office of Indian Affairs, Letters Received, Department of the Interior, Record Group 75, National Archives, Washington, D.C. (hereafter OIA LR).

${ }^{56}$ Commission of Creek delegates, December 1, 1885, Grayson Family Collection, IV-2. 
${ }^{57}$ See an article signed by Creek delegates G. W. Grayson, Coweta Micco, and Ward Coachman; Moses Keokuk and William Hurr for the Sac and Foxes; and G. W. Harkins and H. F. Murray for the Chickasaws reprinted from the Evening Post (New York?) in the Atoka Independent (Atoka, Choctaw Nation), June 5, 1886; Grayson to Alice Robertson, February 17, 1883, Alice M. Robertson Papers, folder 592, box 12, special Collections, McFarlin Library, Tulsa University, Tulsa, Oklahoma; Debo, The Road to Disappearance, 312. The delegates of the Five Civilized Tribes in 1888 included George W. Harkins, W. P. Boudinot, L. B. "Hooley" Bell, Isparhechar, B. W. Carter, George Sanders, and Stan W. Gray in addition to Grayson, "Indian Delegation," Cherokee Advocate (Tahlequah, Cherokee Nation), May 23, 1888.

${ }^{58}$ The commissions of the delegates in 1885 stated that the four had been chosen owing "to the peculiar interest of a portion of our citizens growing out of their allegiance to the United States during the last rebellion." 1885-30524, OIA LR. Debo, The Road to Disappearance, 312; "Indian Delegation," Cherokee Advocate (Tahlequah, Cherokee Nation), May 23,1888 .

${ }^{59}$ Baird, ed., A Creek Warrior, 154-155.

${ }^{60}$ Grayson's correspondence from Washington often bore the letterheads of these hotels. Baird, ed., A Creek Warrior, 156; Mildred Fuller Ewens, interview by author, Eufaula, Oklahoma, October 12, 1989. 
${ }^{6} 1_{\text {George Washington Grayson, untitled manuscript (property of Mildred }}$ Fuller Ewens, Eufaula, Oklahoma).

${ }^{62}$ Interview of Eloise Grayson Smock, 85:369, I-PP.

${ }^{63}$ Mrs. G. W. Grayson to Alice Robertson, January 22, 1923, number 1851, box 20, Alice Robertson Papers, special Collections, McFarlin Library.

${ }^{64}$ Contract between the heirs of walter Grayson and J. W. Smith and R. A. Burton, April 25, 1884, 1884-13480, OIA LR.

$65 \mathrm{~J}$. W. White and R. A. Burton to Commissioner of Indian Affairs J. D. C. Adkins, July 22, 1886, 1888-19456, OIA LR.

${ }^{66}$ Contract between G. W. Grayson and J. B. Luce, July 10, 1886, 188626857, OIA LR.

67 Debo, The Road to Disappearance, 320-321; Telegram from Captain [Richard] Pratt to the Commissioner of Indian Affairs, January 25, 1888, 1888-2287, OIA LR.

${ }^{68}$ Baird, ed., A Creek Warrior, 149, 151; Cherokee Advocate (Tahlequah, Cherokee Nation), May 23, 1888.

${ }^{69}$ Baird, ed., A Creek Warrior, 151.

${ }^{70}$ Grayson to the National Council, October, 1881, 30780, CRN 37.

$\mathbf{7 1}$ The terminology, "alien flood," frequently occurred in Indian 
correspondence of the day. Hoig, David L. Payne, 216-217; Debo, The Road to Disappearance, 330-331. The best full-length study of the humanitarian reformers is Francis Paul Prucha, American Indian Policy in Crisis: Christian Reformers and the Indian, 1865-1900 (Norman: University of Oklahoma Press, 1976).

72 Baird, ed., A Creek Warrior, 163-164.

${ }^{73}$ G. W. Stidham, "What G. W. Stidham Thinks of Vest's Oklahoma Bill," Indian Journal (Eufaula and Muskogee, Creek Nation), January 8, 1880. Choctaw Governor Isaac L. Garvin expressed the same sentiments in his inaugural address, october 8,1878 , "Under the traditional system of land held in common we have neither paupers nor tramps." Records of the Principal Chiefs, 235, Choctaw National Records, microfilm, reel 53, OHS Archives.

${ }^{74}$ Debo, The Road to Disappearance, 235-239.

${ }^{75}$ Testimony before the senate Investigating Committee, 18E, CRN 35 .

${ }^{76}$ Ibid., $27 \mathrm{E}-32 \mathrm{E}$.

${ }^{77}$ Debo, The Road to Disappearance, 239.

${ }^{78}$ Indian Journal (Eufaula and Muskogee, Creek Nation), March 19, 1885.

${ }^{79}$ Ibid.

${ }^{80}$ Ibid. 
${ }^{81}$ Debo, The Road to Disappearance, 320-321; Indian Journal (Eufaula and Muskogee, Creek Nation), January 28, February 25, March 12, 1886.

82 "Compact between the several Tribes of the Indian Territory," 30844, CRN 37.

${ }^{83}$ Indian Journal (Eufaula and Muskogee, Creek Nation), July 8, 1886. ${ }^{84}$ Ibid., January 5, 1887.

85Ibid., January 12, 1887; Debo, The Road to Disappearance, 320-322.

${ }^{86}$ Debo, The Road to Disappearance, 321-322; Indian Journal (Eufaula and Muskogee, Creek Nation), June 9, 1887.

${ }^{87}$ Indian Journal (Eufaula and Muskogee, Creek Nation), June 9, 1887.

${ }^{88}$ Debo, The Road to Disappearance, 322.

${ }^{89}$ Indian Journal (Eufaula and Muskogee, Creek Nation), January 12 , 1888 .

90 "Protest of Creek Delegation against the Passage of H. R. 1277," January 27, 1888, Alice Robertson Papers, Special Collections, McFarlin Library .

91 Muskogee Phoenix (Muskogee, Creek Nation), October 11, 18, 1888; Debo, The Road to Disappearance, 344.

92 Muskogee Phoenix (Muskogee, Creek Nation), March 1, April 19, May 10, August 2, August 16, September 13, November 1, 1888. 
93 pleasant Porter to "Friend Grayson," January 1, 1889, Grayson Family Collection, I-17.

94 Muskogee Phoenix (Muskogee, Creek Nation), October 25, December 27, 1888, February 14, 1889; Baird, ed., A Creek Warrior, 160-161; Porter to Grayson, February 2, 1889, Grayson Family Collection, I-17.

95Unfortunately, the only surviving documents in this exchange are those Porter addressed to Grayson. Porter to Grayson, January 1, January 23, February 2, 1889, Grayson Family Collection, I-17.

96Ibid., January 23, 1889; Debo, The Road to Disappearance, 344.

97 Porter to Grayson, January 23, 1889, Grayson Family Collection, I17.

98 Muskogee Phoenix (Muskogee, Creek Nation), February 28, 1889; Porter to Grayson, February 2, 1889, Grayson Family Collection, I-17.

99 Porter to Grayson, February 2, 1889, Grayson Family Collection, I17.

${ }^{100}$ Indian Arrow (Vinita, Cherokee Nation), November 1, 1888.

${ }^{101}$ Atoka Independent (Atoka, Choctaw Nation), January 8, 1887.

${ }^{102}$ Indian Chieftain (Vinita, Cherokee Nation), March 14, 1889.

${ }^{103}$ Debo, The Road to Disappearance, 344; John W. Morris, Charles R. 
Goins, and Edwin C. McReynolds, Historical Atlas of Oklahoma (Norman: University of Oklahoma, 1976, second edition), Map 48.

${ }^{104}$ An unsigned, undated partial document suggests that this was Grayson's aim. VII-16, Grayson Family Collection; Muskogee Phoenix (Muskogee, Creek Nation), November 22, December 6, 1888, February 14, 1889. 
CHAPTER VI

"SAVE WHAT WE MAY OUT OF THE APPROACHING WRECK"

The Oklahoma Cession marked the beginning of a period of decline for the Creek Nation: Creeks still held their land in common, but their tenure was in jeopardy. They still governed themselves, but outside forces threatened their nationhood. The period from 1889 to 1906 corresponded with a similar phase in George Washington Grayson's life. His political career seemingly came to a dead end, and his business ventures collapsed in bankruptcy. Grayson searched for ways to protect the Creek landbase and the Creeks' right of self-government, for in them lay his personal interests as well as the nation's. Yet by 1906 Creeks lost control over their own destiny, and Grayson bitterly realized that neither "progress" nor calling on the United Stats to uphold its commitments was enough to protect Creek sovereignty.

The winter of 1888-1889 was indeed a critical one for Grayson. Concurrent with the death of his favorite daughter and the realization of the Oklahoma Cession was the possibility of a Federal office for him within the new Republican administration. Union Agent Robert I. Owen, a Democratic political appointee, was resigning. Indian Territory residents speculated that candidates for the vacancy included Leo $\mathbf{E}$. Bennett of Muskogee and Grayson. 1

How much Grayson wanted this appointment and for what reasons must 
be speculation. He did solicit the support of Colonel M. M. Parker, an Omaha, Nebraska real estate agent headquartered in Washington, D. C., in a letter in April 1889, "Businessmen of Texas and the Indian Territory are proposing my name to the President for the position." 2 He added that he had the endorsement of General Clinton B. Fiske of the Board of Indian Commissioners and Dr. Morehouse of New York. 3 Parker granted Grayson's request and told the Commissioner of Indian Affairs, "I have known Mr. Grayson for a good many years, and entertain for him the highest regard, and believe him to be a man of integrity. "4 That Grayson had the support of such people possibly weighed against rather than for him with a conservative Republican administration. Then, too, increasing criticism of the influence of Texas cattlemen in the Indian Territory may have prejudiced his nomination. At any rate, the position went to Leo $\mathrm{E}$. Bennett, perhaps a personal as well as a political defeat for Grayson. 5

Leo E. Bennett, a white man originally from Kansas City, was some years younger than Grayson. Trained as a newspaperman and a doctor, he came to the Indian Territory in 1881 and Eufaula in 1883. There he married Louie, Annie Grayson's younger sister. About two years later the stockholders of the Indian Journal hired Bennett as its editor; this made him also a business associate of the Grayson brothers. But Bennett and the Creek stockholders could not agree, and in a few months the ambitious editor left Eufaula to resettle in Muskogee. There in 1888 he founded the Muskogee Phoenix in competition with the Indian Journal and its job printing department. ${ }^{6}$

That he espoused white boomer attitudes toward the territory did 
not endear him to the Graysons. Nor did his relationship with the famous beauty, Anna Trainor Stidham, widow of Annie's brother, please them. The Graysons never severed the relationship even after Anna married the widowed Bennett; but that, combined with other factors, including Grayson's disappointment in losing the Union Agency position, probably added to the hostility that eventually developed between the two men. 7

As early as the Creek Council session of October 1888 Bennett attempted to siphon off some of the Indian Journal Printing Company's business. For several years the journal had held a charter from the Creek Nation and the title of official organ. At that session, Grayson's company asked for passage of a bill granting it an annual appropriation of $\$ 1,200$ as printer for the national government. One day later Bennett submitted a bill asking that the contract go to the lowest bidder not in excess of $\$ 600$. The Indian Journal bid went to the Judiciary Committee and thence to the Council; enemies in the House of Warriors, of which Grayson was a member, "slyly pocketed" 8 his bid, according to Bennett. On October 16 the $\$ 1,200$ appropriation for the Indian Journal Printing Company passed the Council, but Chief Legus Perryman vetoed it on information that Bennett's bill amounted to less than half that amount. An attempt to override the chief's veto failed after a hot debate. 9

One can only speculate on Grayson's personal involvement in these manipulations. He was present during the opening round but was absent after October 16, the day his daughter died. It is unlikely he was there for the debate on the veto, but other Indian Journal stockholders 
probably were. In present-day terms Grayson's overlapping business and political affairs constituted a conflict of interest, but until that point no one seemed to question them. Nor were there until that time other publishing companies in the Creek Nation. If, as Bennett suggested, the appropriation asked was exorbitant, the stockholders could defend their high bid by noting that the journal was rarely profitable and its value to the Creek Nation as a symbol of progress was beyond price. ${ }^{10}$

But Leo Bennett was quick to seize this opportunity to cut out a competitor. When the Indian Journal condemned Bennett's low bid as evidence of "shoddy goods" and therefore not worth the Council's consideration, the Phoenix countered that this was the "most highhanded and brazen attempt to impose upon one's own kindred that has lately come to our notice." Moreover, little except shoddy goods appeared in "the poorest excuse for a paper that circulates in this country."11 Charge and counter-charge continued for several weekly issues, which probably did not hurt circulation. 12

None of this, of course, warmed the relationship between Grayson and Bennett. But Grayson took charges that the Indian Journal had declined from its former standards and principles seriously, for in January 1889 a new editor succeeded Samuel B. Callahan. Callahan, a mixed-blood and a rising progressive politician, possibly held views too radical to suit the masses of Creeks. ${ }^{13}$ A few days later the cherokee Indian Arrow commented that the Indian Journal under new management "presents...editorial matter far from that of the 'boomer' kind."14 A few months later, Grayson's name appeared on the masthead as associate 
editor and president of the printing company. 15

By August 1889 Bennett was serving as Union Agent at the same time his newspaper was among those joining the chorus of speculation and accusation aimed at Grayson and J. M. Perryman. Earlier that spring they had traveled out to the western half of the Indian Territory in the company of Congressman James B. Weaver of Iowa. There the two Creeks visited old acquaintances on the Wichita-Caddo Reservation near Wichita Agency. Correctly, as visiting among Indians was strictly circumscribed, Grayson and Perryman first called on Agent W. D. Myers to present a letter of introduction from out-going Union Agent Owen. ${ }^{16}$ Owen endorsed them as "reputable gentlemen of good standing among their own people, whose interests they are likely to represent faithfully and well."17 According to Myers, they told him that they wished to advise his charges in light of the pending visit of the Dawes Commission. Myers gave the two mixed-bloods, whom he took for whites, permission to approach the Indians. 18

A few days later Myers was furious when he realized that he had not only mistaken the situation but that Grayson and Perryman had taken four of the Wichita headmen to Texas to sign contracts. Belatedly some of the Indians questioned exactly what it was they had signed. Two, Sergeant Tom and Arleecher, added to the agent's embarrassment when they wrote to the Cherokees about the matter. In mid-May Myers communicated his concerns to the Commissioner of Indian Affairs, and in July rumors of a Grayson-Perryman swindle appeared in the territorial press. The Muskogee Phoenix, while professing not to credit the rumors without proof, noted that such contracts with credulous Indians often stipulated 
fees of 25 percent for legal counsel. 19

Grayson told quite a different story. He explained that he had been acquainted with some Wichita and Caddo chiefs for years, often acted for them in Washington, and had a standing invitation to come to their reservation. Having no clear title by treaty as the Creeks did, these Indians feared another removal and the pending allotment of their lands. Their latest contract for legal advice having expired, they appealed to Grayson to come to Anadarko. 20 There the Indians offered them "genuine aboriginal hospitality."21 Intending to establish the true value for their lands should they be forced to accept allotment, the Indians delegated four men to sign contracts and designate outside agents to represent them for a fee. ${ }^{22}$

Grayson and Perryman acted as these outside agents when they took the four Indian headmen to Texas without notification. Grayson considered it something of a coup that they successfully negotiated a contract for the lease of "hundreds of thousands of acres"23 of WichitaCaddo grasslands. Grayson did not mention then or later another contract, which according to Myers, hired him, ex-Governor samuel J. Crawford of Kansas, and Congressman Weaver to act for the Caddoes, Wichitas, and Affiliated Bands. 24

Reconciling these accounts remains difficult because much of the pertinent documentation is hearsay. The office of Indian Affairs did stop a Grayson-Crawford-Weaver contract in August 1889. Whether the contract was itself objectionable or because of the rumor and speculation, nothing came of it. Nor has this or any other contract survived. If a lease as substantial as that of "hundreds of thousands of acres" of 
the Wichita-Caddo Reservation existed, no murmur of it appeared in the contemporary issues of the Texas Live Stock Journal. Yet that was the interpretation Grayson preferred to give of the incident in his autobiography written thirty years later. 25

In their public explanation at the time, Grayson and Perryman minimized the affair, presenting it as a rather tedious negotiation intended primarily to reassure and accommodate the concerned Indians. 26 Arleecher and Sergeant Tom protested that they were horrified when the agent interpreted the contract for them and they found that they had agreed to sell their land. Grayson, they now understood, had bound them to "the main leaders in the effort being made to open up the Territory."27 But Grayson and Perryman insisted the documents were read and reread and interpreted for about three days, it being our desire that there shall not be even a chance of a misunderstanding. There was no unfairness, misrepresentation or chicanery about this business and we feel satisfied that it was properly understood. Else why do not the delegates and head chiefs enter complaints? 28

Neither sergeant Tom nor Arleecher claimed to be a chief, and sergeant Tom admitted that he arrived after the talks were finished and the contract signed. 29 One might question the interpretation the flustered and angry agent placed on the document. Grayson the rancher might well have leased the lands as an agent for Texas cattlemen, and such a lease could establish the monetary value of the land. But it seems unlikely that Grayson the diplomat, whose sympathies were with these beleaguered tribesmen and who had dealt with them at many an international council, helped bilk them out of their lands.

This, the most serious charge against Grayson's integrity, probably exacerbated conditions in a year of suspicion and accusation in the 
Creek Nation. While other territorial papers mentioned the affair, Agent Bennett's newspaper gave it the most coverage. As of september the Muskogee Phoenix professed disappointment that Grayson and Perryman still had not satisfied their critics. The editor implied that he had seen the contracts that involved the cession of Indian land and a 10 percent fee for legal counsel. In the same edition appeared a letter signed psuedonymously "Iste Maskoke"; it reminded the public of that shortage in Grayson's accounts during his term as National Treasurer. The writer recommended such "old defalcations" 30 be investigated. These innuendoes came at a time Bennett perceived Grayson as a political enemy. Bennett perhaps used the affair to divert attention from a Federal investigation of the Oklahoma Cession that embroiled him as well as several leading Creeks.

If Grayson purposely distanced himself from the actual negotiations of the Oklahoma Cession, he acted wisely. In the following weeks Creeks and outsiders questioned the handling of the $\$ 2,280,000$ payment. Prior to the cession, the creek delegation--Porter, Hodge, and Isparhechar--hired samuel J. Crawford to serve as their legal counsel for a 10 percent fee even though the case involved a straight payment and not a suit requiring legal action. But the office of Indian Affairs deemed the fee exorbitant and refused to approve the contract. However, once the cession was final, the creek delegation, still working with Crawford, withdrew and paid him $\$ 228,000$ from Creek funds in the United States Treasury. 31

In June 1889 the delegation presented a report to the Creek National Council. Porter defended the delegation's action in hiring Crawford 
by noting that time and again the Federal Government refused to pay the Creeks the money it legitimately owed until they employed attorneys to represent them. But by a vote of sixty-seven to thirty the House of Warriors rejected the report because the Office of Indian Affairs had voided the contract. Creek records do not indicate how individuals voted, but subsequent accusations suggest strongly Grayson opposed the delegation's actions. 32

The outcry over the funds continued throughout the summer, and Agent Bennett considered holding an investigation. At some point in the negotiations of the cession, both Grayson and George w. Stidham, Bennett's father-in-law, had been in Washington. Stidham insisted his visit was unrelated to the negotiations, and Grayson had not arrived until the cession was ratified. Bennett, pleading his relationship by marriage to both sides in the controversy, finally disqualified himself and called in a special Federal investigator. Bennett's self-disqualification did not satisfy the suspicious, among whom were Grayson and D. N. McIntosh. They believed several "boodlers"--the Creek delegates, Crawford, and a number of influential lobbyists in Washington--split the money. Conceivably, they also suspected Bennett because of his hesitancy in investigating the affair. ${ }^{33}$

Bennett claimed without naming names that those who objected so strenuously to the attorney's fee were themselves "sharers in the attorneys fees heretofore paid by the creeks." In this instance they "were for once powerless to raise the percentage and pocket the differences, as they had done in former cases." Presumably, he referred to Grayson, for the first time in years not a Creek delegate. The agita- 
tors clamored for "money or blood" 34 and raised such a cry that only an investigation kept the peace. That investigation in July left many questions unanswered, in part because special Agent Robert S. Gardner took some of the most pertinent testimony behind closed doors. Publicly Porter and Hodge defended their actions and their disbursement of the money, including $\$ 60,000$ that went to prominent white merchant clarence W. Turner of Muskogee. In the end, Attorney General W. H. H. Miller vindicated the delegates. ${ }^{35}$ Even so, Bennett warned darkly in september, "this craving for revenge may lead to assassination and other crimes, this having been for years their only method of obtaining their ends. " 36

Such extravagance and shady dealing as that involved in the oklahoma Cession were all too familiar in Creek finances, according to the editor of the Muskogee Phoenix. Again, without naming names, he blamed the great financial losses the Creeks had suffered over the years on the poor quality of past Creek treasurers. Echoing Bennett's charges of fraud in the delegates' paying out enormous fees for legal counsel, he pointedly asked his readers, "Why did one of the present agitators pay 50 percent to secure a claim of $\$ 32,000$ only a year ago? We refer to the Watt Grayson claim." 37 The obvious references were to Grayson, former Creek National Treasurer and representative of the heirs of Watt Grayson.

By December Bennett named Grayson an enemy in reaction to complaints against the agent. His annual report also drew the lines between him and Grayson. Bennett's assessment of the status of the Creeks challenged several of the principles of self-government and land 
tenure Grayson espoused. Bennett called for the extension of the original jurisdiction of the newly created Federal District Court at Muskogee over all criminal and most civil cases among the Five Civilized Tribes. While he stopped short of calling for the dissolution of the national governments, he believed the Union Agency should be abolished and the Constitution and laws of the United States imposed on the Indian Territory. Most Indians, he insisted, would approve allotment if it were offered to them by the secret ballot. Most of those who opposed the idea did so either out of custom, because they believed they could use the system to keep out the boomer and speculator, or they thought the Indian was not ready for it. The most vocal opponents, he charged, were those with some "fat scheme" in mind. 38

These recommendations were public record to which the vigilant. Grayson had access. That he objected strenuously to Bennett's statements and took his objections to Bennett's superiors must be inferred from a heated letter from the Union Agent to the Commissioner of Indian Affairs. He charged that "certain Creek and Cherokee politicians under the leadership of G. W. Grayson and William Jackson with the advise [Sic] of Messrs. Zack Taylor and T. A. Bland" were preparing to attack "my veracity and integrity." Bennett refused to retract his report and stated:

Grayson is a defeated candidate for the position I hold. Jackson is a white man who was the strongest worker for Capt. Hammer, another defeated candidate... Taylor is an attorney from Tennessee who spent a month or so at Eufaula and Muskogee trying to bleed some one connected with the Creek oklahoma Cession. He is the man whom the records of the Indian office will show demanded my suspension from office because he alleged I refused to investigate the creek ten percent council fee. 39 
Bennett concluded,

I have only to say that I am proud these men are not my friends, I cannot sink my manhood to desire their friendship, and the fact that such men fight me is an honor which I highly appreciate. 40

If, indeed, Grayson and the others attacked Bennett, they did not succeed in removing him as Union Agent. He served until Cleveland's reelection swept out Republican office-holders in 1893. He later became a United States marshal, a prominent Muskogee businessman, and mayor of that town. 41 More important than any personal, business, or even political feud between him and Grayson were their different perspectives on the future of the creek Nation and the Indian Territory.

Bennett and the town he called home represented the white and black incursion that Grayson worked so hard to forestall and the prospect he so dreaded, the eventual demise of Creek sovereignty. In 1889 Eufaula was still a small railroad town, an "Indian town" $\mathbf{4 2}$ that took pride in that designation. But it was quickly losing place to Muskogee, some thirty miles northeast up the Katy tracks at Three Forks. Muskogee's real growth came after the Civil War. Its population consisted of freedmen, Indians, and whites. Many of the whites originally came in as licensed traders. Too many, as far as Grayson was concerned, expanded their operations under the guise of "public necessity" to include hotels, bootshops, barbershops, restaurants, millinery stores, and, of course, ranches. These all required additional labor, and so contributed to the legal and illegal non-citizen population of the Creek Nation. Eufaula had its share of these non-citizens, but it had so far maintained its Indian character. Muskogee, on the other hand, symbolized an alien beachhead on Creek soil. 43 
Its non-citizens, including Union Agent and newspaper publisher Bennett, were vocal about their lack of rights in the Creek Nation and demanded "home rule."44 In the summer of 1889 a Congressional delegation visited the creek Nation and enjoyed an enthusiastic reception in Muskogee. 45 The party included members from Missouri and Kansas as well as W. M. Springer of Illinois, author of numerous bills aimed at the Indian, Territory. Grayson in an open letter to the Muskogee Phoenix asked, who were those who gave them such a welcome? They were not Indians, for "Muskogee is in no sense an Indian town" or even a town in which substantial numbers of Indians gathered. Grayson answered his own question: The enthusiastic audience included "those composing that noncitizen element found clustered found around Muskogee which has no interest in our soil, institutions or welfare." 46

Bennett's newspaper found Grayson's conservatism ridiculous. "A certain class of persons have for years been harping upon the tune, 'Muskogee is a white man's town'" when, in fact, Muskogee numbered the largest population of Indians-by-blood in the territory. These "do-asour-forefathers-did" people always condemned any idea, no matter how progressive, if it first appeared in Muskogee. "Well what if it is a white man's move?" the editor demanded. Indians had a role to play; but, he continued, "if it were not for the whiteman...these very pullbacks would be clad in breech clouts and living in ignorance and heathenism." 47 some weeks later the editor remarked on the anniversary of the founding of the Indian Journal, "It is childish folly for one man or a whole army of men for that matter to try and clog the impetus which is moving the Indian people onward to a better and brighter civiliza- 
tion. 48

In truth, by 1889 Grayson reluctantly conceded that change, however undesirable, was inevitable. Commenting on the Congressional visit, Grayson wrote,

That individualization of lands and statehood is our ultimate good we can believe; but that we are ready now, or that we as a people will be ready the next year, or that congress can legislate our full blooded Indians into fitness for so radical a change, we do not believe. 49

Further evidence of his recognition that times were changing appeared in letters to an Indian Journal stockholder in the spring of 1889 . Grayson proposed that the newspaper modify its policy in view of recent Congressional legislation. 50 He recalled that the founders of the newspaper intended it to stand for "certain cardinal principles." Those principles had not changed, but the "policies, plans, and schemes" (his emphasis) must change to suit present conditions. 51

The principles Grayson believed the newspaper must defend were Creek self-government and ownership of the land. He knew that the boomer element so prominent in Muskogee and surrounding states demanded access to Indian land, formal territorialization, and statehood--the sooner the better. In January 1893 Grayson appealed to President Grover Cleveland, whom Indians understood to be somewhat sympathetic to their cause. He reminded him of cleveland's own recent condemnation of the attempt of American immigrants to overthrow the native government of Hawaii and impose an American-dominated regime. Grayson believed the terms "boomer" and "intruder" covered the alien element in both the island kingdom and the Creek Nation. He urged,

Remove and keep out of our country the intruder element as your government has solemnly promised it would do, and we will 
be a happy people without poorhouses, tramps, bomb throwing anarchists, houses of prostitution, whiskey and beer saloons but with a republican form of government quite as fairly administered as it is in Arkansas. 52

Grayson also knew that although the Five Civilized Tribes had avoided falling under the Dawes Act in 1887, their escape was temporary . That became quite evident when Cleveland named Senator Henry L. Dawes head of a commission to visit the territory in early 1893. The purpose of the Dawes Commission was to test the attitude of the Indians and argue in favor of allotment. 53

No one knew better than Grayson the attitudes of the Indians on the issues or the closed mind of the Federal Government. He interpreted for the Creeks at the February-March 1894 conference at Checotah between the international delegates and the Dawes Commission. The delegates insisted that their land-holding system protected the uneducated fullblood while it allowed the educated and ambitious to prosper. They pointed to their prosperous homes, farms, businesses, mines, and wellsupported schools as evidence of their progress. The absence of almshouses and potter's fields in the territory demonstrated the benefits of their communal land-holding system. Unimpressed, the commissioners hinted that Congress might soon repeal their treaties without their consent as it would any useless legislation. If they knew their own best interests, the Indians must accept allotment and eventual statehood. Neither side yielded to the arguments of the other. 54 The commissioners moved on in early April to okmulgee. There they addressed an audience of two thousand Creeks, among them Grayson. At the close of the speeches, they asked the Creeks to step to the right if they opposed allotment and any change in their government. "The whole 
audience in a very orderly manner filed over to the right, "55 the Indian Journal reported. But the Dawes Commission listened instead, according to Grayson, "to only one side in this matter," that of "the outsiders [rather] than to the bona fide citizens." 56

Grayson returned to Washington for the Congressional sessions of 1893 and 1894. He worked closely with the delegates of the Five Civilized Tribes according to the method they had developed in 1888. Together they held the line against allotment, but they could not prevent legislation providing for the survey of their lands. 57

It was not surprising, then, that in 1894 Grayson re-evaluated his position on allotment and found a way to accommodate it. He admitted a distinction existed between the progressive minority and the conservative majority. He stated publicly, "I believe the most intelligent portion of my people are in favor of allotment, but the masses are not, neither do I ever think they will be." He concluded, "I am confident that our only safety lies in allotment among ourselves of all our land. Then we could hope to get rid of the intruders." 58 Allotment on this per capita basis might satisfy those determined to impose it on Indians as a way to undermine tribalism and foster individualism. But by preventing the creation of any "surplus" lands, it would negate a further influx of non-citizens into the Creek Nation.

Although Grayson unwillingly supported allotment, he continued to cling to the principle of Creek self-government. He was not willing to accept the dissolution of the Indian national governments and see that as the inevitable sequel to allotment. In the weeks after he explained his revised views to the press, the Indian Journal radically altered its 
policy of opposition to allotment to support allotment per capita. At the same time, editor $K$. W. Whitmore called for creation of an organization in the creek Nation to work against statehood. 59

Because he understood exactly how matters stood on these issues, Grayson probably shared Whitmore's frustration that summer: The average Creek seemed unconcerned with the findings of the Dawes Commission and blind to the seriousness of its intent. They reasoned that the Federal Government had sold them their land in fee simple and guaranteed them self-government within its bounds in the treaties of 1832 and 1867. They saw no reason to be concerned. When the Creek National Council met in October, Whitmore reported in disgust that the members spent so much time drinking, gambling, riding the carousel, and generally enjoying the attractions of the wide-open Creek capital there was rarely a quorum present to conduct business. "Such scenes as were enacted at the last Creek Council cannot be re-enacted very many more times,"60 he predicted. "Still intelligent Indians [stand] back with a horrified look on their face and express astonishment at the change in sentiment that is being manifested at [Washington] ."61

Grayson no less than Whitmore knew that such exhibitions worked against the Creek government's survival. Those who opposed the continuation of the Five Civilized Tribes as sovereign nations used this and any other shortcoming as an excuse to demand their dissolution. The cries of the white non-citizen for home-rule, the black against any infringement of his civil rights, the law-abiding for protection against the lawless--all redounded on the creeks as evidence of their incompetence and backwardness. Opponents applied the vocabularies and 
demands of contemporary reform movements, whether populist or progressive, to the Indian governments. Hence, charges of political corruption in such affairs as the Wichita-Caddo contracts and the Oklahoma cession did substantial damage. While Grayson fended off Bennett's unsubstantiated charges of personal corruption, he was vulnerable to the charge of "monopolist." 62

These charges originated in the growth of cattle ranching in the Creek Nation. As described before, ranching was a natural outgrowth of Creek agricultural and commercial enterprises and a logical exploitation of their prime blue-stem prairies. The growing post-war demand for beef in industrializing eastern cities encouraged Creeks to graze large herds of their own and imported cattle. As more cattle entered the nation, the national government instituted a grazing tax on foreign stock. Some white ranchers circumvented it by setting up partnerships with Creek citizens. They took advantage of the communal land-holding system to fence pastures, and some enclosures grew so large that they encompassed many square miles of Creek grazing lands. The Grayson brothers were among those enterprising Creeks. In 1892 Grayson, his father-in-law, and another partner obtained a permit to fence in a large pasture on the southern boundary of the nation. In 1894 Grayson fenced two pastures comprising a total of sixteen thousand acres. 63

The practice aroused much criticism. Creek laws enacted to deal with these developments required the rancher to secure the permission of the people living inside the pasture before he erected a fence around it. Many Creeks were willing to put up with the inconveniences for a small payment; but others complained that the fences interfered with 
their freedom, hindered travel, and forced children to walk extra miles to school. They viewed cattlemen such as Grayson's partner Hugh Henry, the McIntoshes, adopted Creek F. B. Severs, and white trader C. W. Turner as exploiting the resources of the nation at the public expense. Isparhechar became a leader of the opposition to these large pastures and in 1890 led a party of Creeks who destroyed Turner's fence enclosing 250,000 acres. Eventually the Creek National Council made pastures larger than one square mile illegal. 64

In the meantime, critics, including the boomer press, found in the pastures a weapon to turn against Creek sovereignty. They construed the pastures with some reason as a "monopoly" of Creek lands. They denounced those Creeks who best demonstrated the enterprising individualism fostered by assimilationists as "monopolists" clinging to the communal land-holding system for their own purposes. In 1895 the Purcell Register, sparring in print with the Indian Journal, charged that the Creek newspaper belonged to "a corporation of Creek land monopolists devoted to the attempt to preserve their special interests from injuries threatened by impending changes." 65

The editor of the Indian Journal denied this. He stated that the journal was owned by G. W. and Sam Grayson, "neither of whom derive an income of $\$ 10$ from a monopoly of creek lands. The gentlemen mentioned have from three to five hundred acres each of farming land in cultivation and any Indian in the Creek Nation not too lazy to fense [sic] it in can have just as good a farm." They also held an interest in some pastures for which they paid five cents per acre per year and from which they received no income. Their opposition to change in the land- 
holding system was "to protect the fruits of their industry from the rapacity of the boomer." If such monopolies existed as the Register charged, he countered, why did not more Creeks, especially the fullblood victims of the practice, not join the demand for allotment? 66

As far as the Grayson brothers were concerned, the argument that they were profiting from the exploitation of their rights as Creeks were rapidly losing force. The days of their personal prosperity were running out as swiftly as those of the Creek Nation. In 1891 Grayson Brothers listed assets totaling $\$ 71,150$. These consisted of their homes, some rental properties, improvements on their acreages, fencing around pastures, several thousand head of livestock, and their shares in the Indian Journal Printing Company. But hard times set in following the Panic of 1893. Farm prices fell, and the great days of pasture leasing and cattle raising ended. Grayson Brothers faced growing competition from other merchants, many of them white, in Eufaula and surrounding towns. Grayson spent many weeks each year in Washington on Creek business, and his own probably suffered from neglect. He received compensation from the nation for his expenses, but it was inadequate and in the form of warrants usually worth far less than their face value. Sam, his partner in business, also held time-consuming offices in the Creek government. By the late 1890s the Grayson brothers and their several enterprises were in deep trouble. 67

So was the Creek Nation. Each year Grayson returned to Washington to continue the fight against allotment and the dissolution of the nation. But each year the fight grew harder and the victory less certain. In 1896 Congress authorized the Dawes Commission to begin 
preparing census rolls of the Five Civilized Tribes in preparation for allotment. Still the nations refused to treat with the Dawes Commission. That was perhaps the one issue on which all the parties fielding candidates in the Creek election of 1895 agreed. 68

Continuing financial problems within the Creek National Government, a recent scandal that led to the impeachment and removal from office of Chief Legus Perryman, and perhaps a general conviction that conservatives would protect Creek interests better than the progressives gave Isparhechar and Roley McIntosh, both full-bloods, the first and second positions in the nation. Unfortunately, for all his native shrewdness and leadership abilities, the elderly Isparhechar was unable to cope with the demands of the office and was forced to rely on literate, English-speaking advisors including Grayson. He respected Isparhechar but understood the old man's shortcomings. 69

During Isparhechar's second term, Congress moved toward dissolution of the national governments. As of 1895 towns in the nation were allowed to set up municipal governments outside Creek jurisdiction. This greatly pleased the non-citizen element that dominated towns such as Wagoner and Muskogee. Congress also extended Federal court jurisdiction over the Creek Nation and made all Creek legislation except negotiations with the Dawes Commission and resolutions of adjournment subject to presidential approval. In 1898 Congressman Charles Curtis, a mixedblood Kaw from Kansas, created the Curtis Act. It placed Indian national funds under the control of Federal rather than tribal officers, provided for immediate abolition of the national governments, and required the citizens of the Five Civilized Tribes to submit to allot- 
ment without their consent. The Indian Territory moved a long way toward the eventual alien control explicitly forbidden in the Removal treaties. 70

The Creeks still had one avenue of escape left. They named a special commission--Pleasant Porter, Joseph Mingo, David M. Hodge, George Alexander, Roland Brown, William Sapulpa, and Concharty Micco-to negotiate with the Dawes Commission. An independent agreement could postpone the imposition of the Curtis Act over the Creek Nation. Progressives were divided on the wisdom of such a step. Grayson, Porter, and a number of mixed-bloods supported negotiation if it resulted in the continuation of their self-government. However, those who had the most influence with Isparhechar preferred to end all negotiation and fight for the validation of their treaties in the supreme Court. Many full-bloods, having lost faith in the ability of the progressives to direct their affairs, stubbornly ignored the negotiations and clung to the guarantees of those old treaties. The chief called a special session of the creek Council in August 1897 and asked for a voice vote by town on continuing the negotiations. The popular mandate was that the negotiations should end, but the Council voted over Isparhechar's objections to negotiate one last agreement. 71

One historian described the agreement the Creek representatives drew up with the Dawes Commission as the worst of any of the Five Civilized Tribes. It left townsites open to the exploitation of the boomers, agreed to allotment with no restrictions to protect the allottees, and removed any weapon of defense from the creek government. Isparhechar turned it over to the Council with strong caveats and 
suggested instead that the Indian nations form a voluntary union in self-defense. In August 1898 the editor of the Indian Journal noted that Isparhechar did not want to call an election to ratify the agreement. But if no election were held, the Creeks would lose any choice between the "Curtis monstrosity and the Creek agreement." He summed up the intransigent Isparhechar as a sincere but conscientious lunatic whose cause was hopeless. The Creek Agreement, on the other hand, was "a wise, just and satisfactory measure." 72

Perhaps better than anyone besides his co-worker D. C. Watson, Grayson understood the contents of the Curtis Act and the Creek Agreement. The Creek Council appointed them to translate the documents into Muskogee for the benefit of the creek public. Grayson attended public meetings in outlying towns to explain the differences between the two documents. While Grayson helped draft the Creek Agreement, he personally had doubts as to its wisdom. ${ }^{73}$

On November 1, 1898 the Creek people voted on ratification. Grayson's early impression was that the Creeks accepted the agreement, a development his associates greeted with jubilation. Later returns suggested the celebration was premature. ${ }^{74}$ Because access to the private thoughts of persons such as Grayson is so rare, it is appropriate to include here at some length his ruminations on the issues and the vote. On the evening before the Creek Council was to hear the result of the vote, he wrote,

No one is able honestly to say what is best to be done. I believe this agreement is best for us; but even if it has been adopted, I can see so many difficulties and dangers ahead for the poor full-blood Indians that I cannot say it is the very best thing that can in present circumstances be done for them. Certain it is, those of them who took part in the election did 
not think so as most of them voted against the proposition. Those opposing the agreement urge that if it is defeated as it should be, the [Federal] government can be easily enough induced to make another agreement with us which would be more satisfactory to the people. Those favoring the agreement answer that in case we fail to adopt it the U.S. will not need to do anything further, since the Curtis bill which is so supremely objectionable to the people is already a law and will go into operation unless arrested in part by the adoption of the agreement.

I must say that I am rather fearful of the result of changing our tribal title to that of individual, but under tribal title, matters in general in our nation seem to be going rapidly from bad to worse, and I think it might be that an intelligent person, can, when his land is allotted to him manage to care for his interests and those of his family better than he can under present conditions, for which reasons I am constrained to favor the treaty. Time alone can tell who and what is right.

If the treaty is accepted, I think the Creeks would occupy at washington the position somewhat of a persona grata and would be able to secure amendments thereto that would afford greater protection to the ignorant in his possession of his lands. There is great danger of the more ignorant of our people being swindled out of their lands by unscrupulous whites unless some safeguards are thrown around them, and I deem it of importance that this point be closely looked after and guarded by those having at heart the real interests of the full-blood Creeks. 15

On November 18 Grayson wrote,

Well it is officially announced this evening that the treaty has been defeated by 152 votes. I am very sorry for this for it leaves me where I know not what next to do. We should expect those defeating the proposition to define a policy that they think if followed, will lead our nation into a safe harbor. All I am sorry for is that I have no faith in their wisdom or ability to offer anything else as good as the agreement just defeated. 76

On Saturday morning, November 19 the Creeks convened in what

Grayson considered a most important event. By joint resolution, the two houses gathered as was their custom on the north front of the capitol at Okmulgee so that ordinary Creek citizens could listen to the proceedings. The committee charged with counting the votes from the fortyseven towns announced the defeat of the agreement. Then Chief Ispar- 
hechar, the second chief, and Federal Inspector J. George Wright, acting for the Department of the Interior, addressed the assembly. Grayson translated the chiefs' remarks into English while David M. Hodge translated Wright's into Muskogee. Wright spoke at length, but only one thing was important to Grayson: "Today our government was ended and was superseded by the Curtis Bill." 77

His pain was evident in his comments on the events of the day.

After having for 50 or 60 years under the rights guaranteed them by solemn treaties of the United States, the Creeks today had the humiliation of having their government declared to be at an end from and after this date by a representative of the United states. That the life of our government had been trembling in the balance, we had known for several days past, as it had developed that the vote in the recent election on the question of the Creek-Dawes treaty was very close. Its adoption would have continued it perhaps for a few years; its rejection ended it all at once. $\mathbf{7 8}$

Later as Grayson reflected on the recent event, he noted that he had perhaps attended his last Council session. He noted wistfully that some changes seem terrible when they happen but work out for good in the end. "I very much wish this change which has divested us of our right of self-government will prove to be such."79

The immediate imposition of the Curtis Act removed the power of the Creek national government while allowing it to continue to operate indefinitely until the affairs of the nation, primarily the disposition of national property and allotment, were concluded. This meant that in 1899 the Creeks held an election for the positions of chief and second chief. This offered Grayson one last opportunity to run for the primary office. 80

Although political violence no longer racked the nation after 1883, Creek politics fractured far beyond a simple split between conservatives 
and progressives, full-bloods and mixed-bloods. Ephemeral parties and coalitions appeared and disappeared by the next election. Creek freedmen and those claiming to have been Creek slaves formed a bloc able to swing elections to suit their interests. Grayson perhaps gravitated toward the more conservative mixed-blood faction favoring allotment per capita only as a last resort and continuing self-goverment. This put him at odds with the rising political star among progressives, pleasant Porter, who represented the old Unionist faction. 81

In 1899 Porter ran on a platform of compromise with the Dawes Commission. On his ticket in the second position, representing the full-blood interests, was Moty Tiger. Their opponents were two tickets, one consisting of former chief Legus Perryman, now firmly identified with the boomer element, and William McCombs; the other of Roley McIntosh, a full-blood adopted by that prestigious mixed-blood family, with Grayson for second chief. The McIntosh-Grayson ticket finished third with only half as many votes as porter and Tiger. The final disposition of national affairs, then, were in Chief Porter's hands. 82 In spite of Grayson's defeat, he remained active in Creek affairs, though perhaps with less influence than he had enjoyed during earlier administrations. Grayson represented coweta Town in the House of Warriors throughout the 1890s. At Okmulgee he boarded across the from the capitol at the home of police chief Dick Farr. During the day he took his place in the second-floor chamber of the imposing stone building the Creeks erected in 1878, and periodically he presided over the House of Warriors as speaker pro tem. In addition, he served on the Council's education and finance committees. However large the crowd 
during Council sessions in Okmulgee, Captain Grayson's flowing white beard set him apart from all the dark faces. 83

Chief Porter, educated and fluent in English and Muskogee, needed Grayson less than had Isparhechar; but Grayson was welcome in the first floor executive office. He continued to serve as a delegate to Washington and to the international conferences until the end of the decade. Porter called on Grayson for advice and translation of his speeches. The Seminoles, who also spoke Muskogee, also hired Grayson to translate their laws and constitution. ${ }^{84}$

By 1899 Grayson found it increasingly necessary to take such odd jobs as translation, for Grayson Brothers was sliding deeper into financial trouble. Wash and Sam Grayson understood that the allotment demanded by the Curtis Act, though still pending, was inevitable. The laws of the Creek Nation stipulated that an individual's improvements on communal land were exempt from bankruptcy. Until the land on which Eufaula stood passed out of the possession of the Creek Nation, their homes were safe. If they were to save something from their years of enterprise, they must do it before the Creek Council and the Dawes Commission reached a formal agreement on allotment and placed the Eufaula townsite under individual title. Consequently, in 1899 the Grayson brothers filed bankruptcy. They lost the part of their wealth that was invested in four thousand head of cattle. They probably lost their shares in the Indian Journal at this time, too. But they kept their homes, perhaps one last coup against the white acquisitiveness they blamed for their personal and national losses. 85

The long-dreaded allotment loomed over the Creeks for some years. 
The survey of the land and the enrollment of creek citizens proceeded through the late 1890s. The Grayson family, as opposed as they were to the policy, enrolled and chose their allotments early. Each citizen was supposed to receive 160 acres worth a standard valuation of $\$ 1,040$, or $\$ 6.50$ per acre. The national funds were to offset any difference between the value of the actual allotment and the standard valuation. Grayson chose adjoining allotments for himself, Annie, and his minor children Washington, Eloise, and Tsianina in the fertile bottomlands of the North Fork River at Fame, about five miles northwest of Eufaula. This allowed the convenience of joint cultivation and oversight of the property. He took an additional small acreage next to that of his adult son, Walter Clarence, and his daughter, Lenore, just east of Hugh Henry's allotment near Henryetta, an area coming into prominence for its coal deposits. Grayson also performed a last duty to the people of Coweta Town by choosing allotments for several town members. There is no evidence that he ever profited from these selections as was too often the case during the heyday of the "grafters." 86

Not all Creeks were so cooperative in the matter of choosing allotments. More traditional Creeks, unable to accept the alien policy that had historically worked to their disadvantage, ignored the agreements between the progressive leadership and the Dawes Commission. They refused to choose allotments or to accept the patents giving them individual title to the lands they farmed. Some talked of moving voluntarily beyond the control of the whites and the progressive Creeks, perhaps to Mexico or to Paraguay. Others repudiated Chief Porter and the entire constitutional government to rally around Chitto Harjo 
(Wilson Jones) in an incident known as the Crazy snake Rebellion. At Hickory Ground west of Eufaula, these traditionalists set up an independent government, organized a lighthorse to enforce their laws, and threatened those who accepted allotments. They interfered so seriously with allotment that Federal marshals arrested them and delivered them to Muskogee for trial. The Federal judge, sympathetic to their cause, sentenced them to prison but then released them on the provision that they accept their allotments. Progressive Creeks such as Porter, Grayson, and editor Alexander Posey of the Indian Journal, although they knew the cause of the snakes was hopeless, sympathized with their distress. 87

Over the objections of the snakes, allotment continued. There were complaints that the more knowledgeable mixed-bloods took the prime lands, leaving the poorer grades to the reluctant conservatives. As town lots became available in the newly platted towns, the Grayson family claimed at least twenty-six lots in Eufaula for which they paid a total of $\$ 978$. This was fairly modest compared to the acquisitions of town lots under the liberal Creek Agreement of 1901 that allowed such men as Porter, C. W. Turner, F. B. Severs, David M. Hodge, and William A. Sapulpa to engross substantial areas. Turner and Porter, partners in a large pasture within the limits of Muskogee, purchased land either at face value, half-price, or by proxy. Porter owned nearly one hundred thousand dollars' worth of real estate at his death in 1906.88

Grayson was only one of many Creeks, including Porter, who doubted that the Creek Agreement of 1901 was sufficiently protective of Creek allottees. In 1902 a Supplemental Agreement addressed some of their 
fears and provided for the appraisement of Creek lands. The Appraisement Committee included three white members with Grayson as the Creek representative. With allotment a reality, Grayson was still determined to protect the individual Creek's ownership of the land. The committee traveled all over the Creek Nation that summer appraising allotments preparatory to the equalization of allotment values. Grayson looked about him during his extensive travels, and he saw his worst fears of allotment realized. 89

Grayson wrote to Assistant Secretary of the Interior Thomas Ryan, an old acquaintance, about the injustices he saw inflicted on his fellow Creeks. Grayson explained, "many men, myself among the number, believing that it was the wiser course to align ourselves in harmony with the proposed change... and save what we may out of the approaching wreck," accepted allotment. But they had insisted on the prohibition of alienation of title to protect the full-bloods. In spite of that stipulation, unscrupulous white men, "grafters," were bilking Creeks out of their lands. Every town in the nation now had its land dealers. The large companies maintained offices in the towns and boldly advertised in the newspapers. "We find the small dealers panting and covered with perspiration and dust calling at the homes of our people and negotiating single handed with individual members who are needy and have more land than money. 90

These grafters induced Creeks to lease their lands for ridiculously low amounts of cash. No sooner did the naive Creek get his patent than he handed it over to a grafter, all in violation of the law. Such manipulations tied up thousands of acres of Creek land. "One thing that 
is painfully certain," Grayson concluded, "is that [the full-bloods] are unable to cope with the white land buyers now abroad in our land."91 He called for an investigation and action against the lease-buyers. The Office of Indian Affairs referred his letter to Indian Inspector $\mathrm{J}$. George Wright, who replied that he was well aware of what was going on but that there was no real penalty for making illegal leases except the expulsion of the lease-holders. 92

Grayson's work with the Appraisement Committee convinced him that Federal officials were also intent on stripping Creeks of their property. The committee went into the field with a schedule of eighteen classifications of land ranging from natural open bottom land, valued at $\$ 6.50$ per acre, to flint hills, valued at $\$ .50$ per acre. ${ }^{93}$ This was in accordance with the understanding of the creek Council that the basis of evaluation was agricultural. But Grayson soon learned that the committee was using a different schedule which classified land within two miles of a railroad at $\$ 6.50$ regardless of its worthlessness for agricultural purposes. At the same time, much of the hilly, rocky country of the western nation overlying valuable oil pools was not even being classified. Grayson suspected little attempt at equalization would be attempted if most of the land were classified at the prime rate, while the unclassified western lands would create an irresistible temptation for the oil corporations and congress. "To one in interest, \& so well acquainted with the rapacity, the greed, and cunning of those who are after us on all sides as I am," Grayson wrote to Chief Porter, "it must be conceded that these fears \& suspicions are natural as well as logical. 94 
Grayson's general pessimism concerning the results of allotment and insistence that the Creek government continue to function as long as possible placed him at odds with Chief Porter. Porter, at least in the beginning, professed to expect great things from allotment. "It will be a good thing for us, for it will impose obligations on each member of the tribe which he has been relieved of heretofore," he told a newspaperman in early 1901. "Every man must shift for himself, \& the result will be that thrift \& frugality will be practiced and the members of the tribe started on the road to financial success." 95

Porter also looked forward to the end of Federal control of their affairs as stipulated in the Curtis Act. The act permitted Federal officials to take over Creek affairs, finances, and schools. The Creeks had not always spent their money wisely, as Grayson was the first to admit; but they had taken pride in their schools and staffed them with Creek educators in the hope of lifting their people to a higher stage of civilization. Now Creeks found Federal control onerous and restrictive, Federal spending of their funds extravagant, and the Federal school administrators openly contemptuous of creek education. 96 Porter was impatient for the end of the allotment process and Federal control even though this would mean the formal end of the Creek Nation. Porter declared, "I tell you it will be a novel but glorious experience when we are at last ushered into the great highway of individual manhood. We will feel like people who are born and reared in prison and all at once are turned loose in the broad world to do as we pleased." 97 How much Grayson's advice and findings influenced Porter's opinions must be conjecture. By the end of 1904, Porter was urging Creeks 
not to sell so much as a foot of their land, even though some were too old or impoverished to work their allotments. One editor remarked that he hoped this indicated "the clouds roll away from the chief's mental horizon." 98 Grayson must have believed he had something better to offer in terms of leadership because he attempted to run against Porter for the chieftaincy in 1903. It was generally believed that the winning candidate would be the last chief the Creeks would ever elect.

Little information about that campaign has survived other than the inimitable description of Alexander Lawrence Posey. Posey was a mixedblood Creek, reared near Eufaula, a product of Creek schools, and a progressive. He was a generation younger than Grayson, but the two were friends and fellow intellectuals bound together by their love of writing and their deep concern over Creek affairs. 99 Posey also worked with the Dawes Commission enrolling sometimes reluctant allottees. He won general respect and admiration as an educator, writer, and editor of the Indian Journal. He was a poet under the pseudonym "Chinnubie Harjo" and a writer of political satire under the pseudonym "Fus Fixico," in many ways a forerunner of Will Rogers. His conversations in dialect featured full-bloods Fus Fixico and Hotgun and their friends, Wolf Warrior (the English translation of Grayson's Creek name, Yaha Tustunnugee) and Kono Harjo. The major contribution of these last two characters was to listen closely and spit into the weeds. They remembered "the ol' days when Checota was chief an' Injin Territory was a hunting' groun' for the Five Tribes 'stead of a paradise for Illinois politicians." 100

In June 1903 Posey, perhaps with some bias, described through one of their conversations the caucus at which Grayson made his bid to be 
the last chief.

Well, so Legus Perryman was a sly old coon and was made Wolf Warrior hide out up to Okmulgee. Hotgun he say, 'Well, so how he do it?'

And Tookpafka Micco he say, 'Well, so they was had a big fight over the last bone."

Then Hotgun he say, 'Well, so what Chief Porter do when they was get into it?'

And Tookpafka Micco he say, 'Well, so he was just set off to one side and watch the wool fly and glad he was not had a hand in it.'

.... Then Hotgun he say, 'Well, so what kind a bone Legus Perryman and Wolf Warrior was had a fight over?'

And Tookpafka Micco he say, 'Well, so they was had a big caucus up to okmulgee to see who be the last chief. They was get together in the council house and Marcey Harjo was called the roll and say, "Well, so they was about thirty-one towns had delegates here."

'This was sound like hombux che (make ready to eat) and Legus Perryman and Wolf Warrior was get ready to help theyselves. Then the chairman he say, "Well, so who you was want for next chief?" and they was put near all hold up their hands for Legus Perryman, and it was made Wolf Warrior look like white folks that didn't get to the first table. Then the chairman he say, "Well, so it's carried like a shack on a headrise in Oklahoma." So this was bust up the powwow...'

Then Hotgun he say, 'Well, so I was mighty sorry old Legus got nominated, 'cause he ain't a fullblood Injin." And Tookpafka Micco he say, 'Well, so good men like Wolf Warrior don't all time get in office.'

Then Hotgun he say, 'Well, maybe so that's why it is old Legus was carried off the bone.,101

One can only speculate on Grayson's feelings at having been cut out of the nomination for the chieftaincy. His entire life as an adult had been spent in the service of the Creek Nation, and the stepping into the chieftaincy was the logical last step. That he wanted to be chief must be inferred if Fus Fixico's account is accurate. But in 1903 the Creeks, with some reservations, re-elected Porter over three candidates representing the booster, moderate conservative, and full-blood factions. By this time, half the voters in the Creek Nation were freedmen. 102 Fus Fixico summarized the campaign, 
Well, so I see in the newspapers they was lots a candidates for Creek Chief 'sides Pleas Porter and Charley Gibson and Legus Perryman and Yaha Tustunnugee. But I think it was laid between Yaha and Charley 'cause they get all the Injin votes and was left nothing for Pleas and Legus but niggers to vote for them and maybe so a few half breeds that was hungry for pie. ${ }^{103}$

So Pleasant Porter began a second term in 1903 with the general assumption that he would be the last Creek chief. Knowledgeable men understood that the dissolution of the nations and statehood must come soon. Looking toward these events, at the 1904 Council session, Grayson, Porter, Ben Marshall, Roley McIntosh, and A. P. McKellop joined Cherokee Robert $\mathrm{L}$. Owen in attempting to organize a political party limited to Indians by blood. They explicitly excluded blacks. They intended to create a strong independent party that could, with as many as fourteen thousand voters, hold the balance of power after statehood, should the Indian Territory be joined to Oklahoma. This party apparently died at birth for no other mention of it appeared in territorial papers. 104

To avoid the union of the two territories, Indian citizens made one last attempt to create a separate Indian state. In July 1905 Grayson served as interpreter as Creeks met to discuss the recent single statehood convention at oklahoma City. 105 It was the preliminary to a fullscale constitutional convention, organized primarily by Porter, Charles N. Haskell, and William H. "Alfalfa Bill" Murray, at Muskogee beginning August 21. Grayson, a delegate from District 12 and one of 182 delegates from the Indian Territory, was appointed to the committee charged with drafting the preamble and declaration of rights and powers. In the preamble the delegates named the proposed state "Sequoyah." Had Grayson 
had his way, the state would have been called "Tecumseh" after the great Shawnee leader of resistance against the Americans. The convention produced the sequoyah Constitution, a document historians have since judged well-written, an example of Indian political ability, and a forerunner of the state Constitution of oklahoma. Indian Territory citizens ratified it by a vote of more than five to one on November 7 , 1905. But Congress, that had in 1870 insisted on statehood for the territory, rejected the constitution and ended any hope of separate statehood. 106

How Grayson felt about the outcome must be conjecture. That he said little about the convention, either publicly or privately, suggests that he gave little real importance to it in spite of his participation. Perhaps he saw too much white leadership in the convention in the persons of Murray, Haskell, and a number of intermarried or adopted citizens. Perhaps his intimate knowledge of Congress and the Federal bureaucracy convinced him the cause was hopeless. His last mission to Washington as a delegate with Chief Porter in the winter of 1906 must have reinforced that conclusion: Even though they went at the express invitation of the Interior Department to help draft the last act dealing with their national dissolution, the Congressional committee they were to aid virtually ignored them. Porter returned home and left Grayson on guard alone in Washington. Twelve days later on March 4, 1906, in compliance with the Creek Agreement of 1901, the Creek Nation ceased to exist even though its affairs still far from finished. 107

How bitter this time must have been for Grayson, who had defended the Creeks' right of self-government and possession of their domain for 
four decades. No matter how hard they fought, no matter how well they organized and plotted strategies of unified resistance, no matter how well they demonstrated their progress toward white-style civilization, they could not withstand the alien flood. About 1912, Grayson wrote a summary of this latest period of Creek history that reverberated with his sense of injustice:

Here we, a people who had been a self-governing people for hundreds and possibly a thousand years, who had a government and administered its affairs ages before such an entity as the United States was ever dreamed of, are asked and admonished that we must give up all idea of local government, change our system of land holding to that which we confidently believed had pauperized thousands of white people--all for why; not because we had violated any treaties with the United states which guaranteed in solemn terms our undisturbed possession of these; not because of any respectable number of intelligent Indians were clamoring for a change of conditions; not because any non-enforcement of law prevailed to a greater extent in the Indian territory than elsewhere; but simply because regardless of the plain dictates of justice and a christian conscience, the ruthless restless white man demanded it. Demanded it because in the general upheaval that would follow the change he, the white man, hoped and expected to obtain for a song, lands from ignorant Indians as others had done in other older states. 108 
NOTES

$1_{A}$ third candidate was a Captain Hamar or Hammer of Fort Smith, Arkansas. Indian Chieftain (Vinita, Cherokee Nation), January 17, January $31,1889$.

Existing documentation provides no evidence of who these Texans were, nor does Grayson's personnel file in Federal records include any letters of recommendation. Grayson to Parker, April 1, 1889, 1889-8812, Office of Indian Affairs, Letters Received, Department of the Interior, National Archives, Washington, D.C. (hereafter cited as OIA LR).

3 Ibid.

${ }^{4}$ Parker to the Commissioner of Indian Affairs, April 5, 1889, ibid.

5 Muskogee Phoenix, April 11, 1889.

${ }^{6}$ James T. Grady, ed., The State of Oklahoma: Its Men and Institutions (Oklahoma City: The Daily Oklahoman, 1908), 98; H. F. O'Beirne and E. S. O'Beirne, The Indian Territory: Its Chiefs, Legislators, and Leading Men (St. Louis: C. B. Woodward, 1892), 122-124; Indian Journal (Eufaula and Muskogee, Creek Nation), May 5, 1887, January 12, 1888; The Indian Missionary (Atoka, Choctaw Nation), January, 1888.

${ }^{7}$ Anna was the "Indian maiden" in the symbolic wedding of the Indian and Oklahoma territories enacted on statehood day, 1907. "The Stidham Family," Vertical File, Oklahoma Historical Society Library, Oklahoma City, Oklahoma; The Daily Oklahoman (Oklahoma City, Oklahoma), November 
17, 1957; Mildred Fuller Ewens, interview by author, Eufaula, Oklahoma, October $12,1989$.

8 "Sour Grapes," Muskogee Phoenix (Muskogee, Creek Nation), November 1,1888 .

${ }^{9}$ Ibid.

${ }^{10}$ Perryman to the National Council, october 17, 1889, 34093, Creek National Records, microfilm, reel 40, OHS Archives (hereafter cited as CRN); "Sour Grapes," Muskogee Phoenix, November 1, 1888.

11"Sour Grapes," Muskogee Phoenix, November 18, 1888.

12 Muskogee Phoenix, November 15, 29, 1888.

${ }^{13}$ Indian Journal (Eufaula and Muskogee, Creek Nation), January 3, 1889; Muskogee Phoenix, December 20, 1888; Indian Chieftain (Vinita, Cherokee Nation), December 22, 1888.

14 Indian Arrow (Vinita, Cherokee Nation), January 10, 1889.

${ }^{15}$ Indian Journal (Eufaula and Muskogee, Creek Nation), November 14, 1889.

${ }^{16}$ Bennett owned the Muskogee Phoenix until 1893. Grady, ed., "Leo E. Bennett," The State of Oklahoma, 98; Muskogee Phoenix, May 9, 1889; Agent W. D. Myers to the Commissioner of Indian Affairs, May 13, 1889, 1889-13332, OIA LR. 
${ }^{17}$ Owen to Whom It May Concern, April 23, 1889, ibid.

${ }^{18}$ The Dawes Commission visited the tribes to whom the Dawes Act applied to persuade them to accept and choose allotments as the preliminary steps to opening their reservations. Myers to the Commissioner of Indian Affairs, May 13, 1889, ibid.

${ }^{19}$ Ibid., Indian Arrow (Vinita, Cherokee Nation), July 25, 1889; Muskogee Phoenix, July 25, August 1, 1889.

${ }^{20}$ Muskogee Phoenix, August $22,1889$.

21 W. David Baird, ed., A Creek Warrior for the Confederacy: The Autobiography of Chief G.W. Grayson, Civilization of the American Indian, volume 189 (Norman: University of Oklahoma, 1988), 150.

22 Muskogee Phoenix, August $22,1889$.

23 Baird, ed., A Creek Warrior, 150.

24 Myers to the Commissioner of Indian Affairs, August 17, 1889, 188923707, OIA LR.

25 Ibid. Grayson had worked with Crawford in 1884 when the latter was hired as Creek attorney by the Creek delegates. Grayson to Chief J. M. Perryman, July 18, 1884, 39223, CRN 50; Baird, ed., A Creek Warrior, 149-150.

26 Muskogee Phoenix, August 22, 1889. 
${ }^{27}$ Ibid., August 1, 1889.

${ }^{28}$ Ibid., August $22,1889$.

${ }^{29}$ Ibid. , August 1, 1889.

${ }^{30}$ Ibid., September 12,1889 . See pages 137-138 above.

${ }^{31}$ Ibid., June 27, 1889; Indian Arrow (Vinita, Cherokee Nation), April 25 , August $8,1889$.

${ }^{32}$ The House of Kings refused to act on the report. Indian Arrow (Vinita, Cherokee Nation), August 8, 1889; Muskogee Phoenix, August 22, 1889.

33 Among those listed as laying charges against the delegates were D. N. McIntosh, William E. Gentry, Dick Lerblance, William Fisher, and Hence Posey. McIntosh and Gentry were, of course, close Grayson associates. Muskogee Phoenix, August 1, 29, 1889; Acting Commissioner of Indian Affairs R. V. Beer to United States Special Indian Agent Robert $S$. Gardner, June 24, 1889, LB 186/223, volume 65, Letter Book, Correspondence, Land Division, Office of Indian Affairs; Indian Arrow (Vinita, Cherokee Nation), July 25, 1889.

34 Bennett to the Commissioner of Indian Affairs, September 21, 1889, Commissioner of Indian Affairs, Annual Report (Washington, D.C.: Government Printing office, 1890), 209 (hereafter cited as AR CIA). 
${ }^{35}$ Indian Arrow (Vinita, Cherokee Nation), August 8, 1889; Muskogee Phoenix, September 19, 1889.

${ }^{36}$ Bennett to the Commissioner of Indian Affairs, September 21, 1889, AR CIA 1889, 209.

${ }^{37}$ Muskogee Phoenix, September $12,1889$.

${ }^{38}$ Bennett to the Commissioner of Indian Affairs, September 21, 1889, AR CIA 1889, 203-204.

${ }^{39}$ Bennett to the Commissioner of Indian Affairs, December 5, 1889, 1890-9993, OIA LR. Ex-Congressman Zack Taylor of Tennessee reportedly conferred with Secretary of the Interior Noble about his employment as the special investigator. Indian Arrow (Vinita, Cherokee Nation), July $25,1889$.

${ }^{40}$ Bennett to the Commissioner of Indian Affairs, December 5, 1889, OIA LR 1890-9993.

${ }^{41}$ Grady, ed., The state of Oklahoma, 98.

42 Muskogee Phoenix, April 25, 1889.

43 The population of Eufaula in 1890 was 500 compared to Muskogee with 1,200. Angie Debo characterized it as a "vigorous foreign settlement on Creek soil," in The Road to Disappearance: A History of the Creek Indians, Civilization of the American Indian (Norman: University of Oklahoma, 1941), 231, 246-247, 332. The Creek delegates (George W. 
Grayson, Samuel Checote, D. M. Hodge, and Isparhechar) to Commissioner of Indian Affairs H. Price, February 18, 1884, 39191, CRN 50; Grayson and Hodge to Price, March 22, 1884, 39208, ibid.

44 Muskogee Phoenix, April 11, 1889.

${ }^{45}$ Ibid., September $26,1889$.

${ }^{46}$ Ibid., October 3, 1889.

${ }^{47}$ Ibid.

${ }^{48}$ Ibid., November 28, 1889.

${ }^{49}$ Ibid., October 3, 1889.

50 Grayson to N. B. Moore, April 26, 1890, number 847, May 9box 14, Special Collections, McFarlin Library, Tulsa University, Tulsa, Oklahoma.

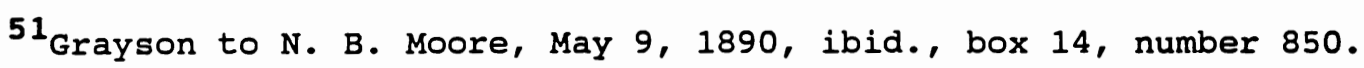
52 Grayson to President Cleveland, January 15, 1893, 1894-4321, OIA LR.

53 Debo, The Road to Disappearance, 346 .

54 Indian Journal (Eufaula and Muskogee, Creek Nation), February 15, 22, March 1, 1894; Debo, The Road to Disappearance, 346-348.

55 Indian Journal (Eufaula and Muskogee, Creek Nation), April 12, 1894. 
${ }^{56}$ Indian Journal (Eufaula and Muskogee, Creek Nation), March 1, 1894. 57 Debo, The Road to Disappearance, $346,348$.

${ }^{58}$ vinita Chieftain, quoted in the Indian Journal (Eufaula and Muskogee, Creek Nation), March 1, 1894.

${ }^{59}$ Indian Journal (Eufaula and Muskogee, Creek Nation), March 8, April 5,1894 .

${ }^{60}$ Ibid., October $12,1894$.

${ }^{61}$ Ibid., November $16,1894$.

62 Indian Journal (Eufaula and Muskogee, Creek Nation), December 21, 1894. See also the issue of February 15, 1895: The Dawes Commission reported to the Board of Indian Commissioners after visiting the Indian Territory that the Indian courts and legislatures were corrupt, the schools primitive, crime unpunished, the lands engrossed by "a few enterprising half-breeds," and the whites without rights--all this among nations held up as models of Indian progress. During this period, Grayson's brother Sam, Creek National Treasurer, was impeached and forced to resign in connection with the unauthorized issuance of warrants. Angie Debo concluded that his wrongdoing was "irregular, but not necessarily dishonest." Debo, The Road to Disappearance, 326-327, 358-359.

${ }^{63}$ Some others were Pleasant Porter, S. B. Callahan, E. H. Lerblance, and William E. Gentry. Permits for pastures, 36960, 35002, 35003, CRN 42 . 
64 Debo, The Road to Disappearance, 336-343; interview of Mrs. R. M. Tiger, 91:83-85, Works Progress Administration, "Indian-Pioneer Papers," microfiche, University of Oklahoma, Norman, Oklahoma (hereafter cited as I-PP).

${ }^{65}$ Indian Journal (Eufaula and Muskogee, Creek Nation), June 8, 1895. ${ }^{66}$ Ibid.

${ }^{67}$ Bond for Sam Grayson for $\$ 80,000$ as Creek National Treasurer, December 5, 1891, 39350, CRN 51; Harold Grayson Hoppe, "In Re Grayson: A Critical View from a Native American Perspective," (an unpublished paper, property of Harold o. Hoppe, Wichita, Kansas).

68 Arrell M. Gibson, The American Indian: Prehistory to the Present (Lexington, Mass.: D. C. Heath and Company, 1969, paperback edition, 1980), 502; Debo, The Road to Disappearance, 361.

${ }^{69}$ Debo, The Road to Disappearance, 361-362.

70 Ibid., 364-365, 371; William E. Unrau, Mixed-bloods and Tribal Dissolution: Charles Curtis and the Quest for Indian Identity (Lawrence: University of Kansas Press, 1889), 119-124.

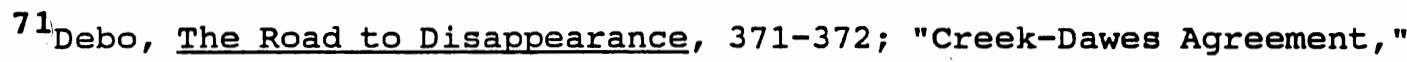
Document Number 5, 55th Congress, 3rd Session, House of Representatives, Indian Affairs, Department of the Interior, Annual Report for the Fiscal Year Ended June 30, 1898 (Washington, D.C.: Government Printing Office, 
1898), 448; Address of Isparchechar to the National Council, August 24, 1897, VII-29, Grayson Family Collection.

${ }^{72}$ Indian Journal (Eufaula and Muskogee, Creek Nation), August 26, 1898.

${ }^{73}$ Ibid. , August 18, 1898.

${ }^{74}$ Grayson to Commissioner of Indian Affairs William A. Jones, November 4, 1898, 1898-50457, OIA LR.

${ }^{75}$ quoted in Harold 0 . Hoppe, "The Dissolution of a Nation: A Muscogee Retrospective," (an unpublished paper, property of Harold 0. Hoppe, Wichita, Kansas), 26. Grayson's reference to the "Curtis bill" is somewhat misleading. The act was passed on June 28,1898 but did not affect the Creek Nation until November 19, 1898.

${ }^{76}$ Ibid.

77 Ibid., 27.

$78_{\text {Ibid. }}$

${ }^{79}$ Ibid.

${ }^{80}$ Debo, The Road to Disappearance, 373.

${ }^{81}$ Ibid., 324-325, 361; election returns of september 3, 1895, 29586, CRN 34.

82 Election returns of 1899, 35654, CRN 23. 
${ }^{83}$ Election returns for the House of Warriors, September 20, 1897, V31, Grayson Family Collection; documents of October 14, November 24, 25, December 1, 1899, Creek Indian Memorial Association Collection, OHS Archives; Carselowey Collection, 103:156, I-PP; Okmulgee Daily Newg, December 3, 1920.

${ }^{84}$ Delegates to the International Council at Okmulgee, July 8, 1896, 30869, CRN 37; statement of expenses of the Executive Office, December 5, 1901, 35671, CRN 23; Laws and Constitution of the Seminole Nation, 109, Seminole National Records, microfilm, reel 1, OHS Archives.

${ }^{85}$ Harold Grayson Hoppe, "In Re Grayson," 15-16.

${ }^{86}$ These allotments lay in sections 5,8 , and 17 , range 16 east, township 10 north. Grayson's land near Henryetta lay in sections 8 and 16, range 13 east, township 11 north. Abstract of the Annual Report of the Commissioner to the Five Civilized Tribes for the fiscal year ended June 30, 1911, 5-1, Central Classified File, Part 1, Indian office, Department of the Interior, NA (hereafter cited as CCF); E. H. Hastain, Township Plats of the Creek Nation (Muskogee, Oklahoma: n.p., c. 1908)., 168-169, 236-237; Census Roll, Coweta Town, Muskogee Nation, box 1, Division of Manuscripts Collections, WHC.

${ }^{87}$ James R. Gregory to Chief Isparhechar, July 28, 1899, 32453, CRN 23; Porter to J. Blair Schoenfelt, $\wedge$ June 29, 1900, Executive office Records, 152-156, CRN 22; Tahlequah Arrow, November 21, 1903; Indian Journal (Eufaula and Muskogee, Creek Nation) April 24, 1908. 
${ }^{88}$ Conveyances by the Principal Chief in the Town of Eufaula, November 6, 1903 through August 31, 1907, (1903) 8296, (1905) 1177, (1906) 17762, (1906) 81804, box 12, Indian Territory Division, Department of the Interior, Record Group 48, NA (hereafter cited as ITD); Ralph William Goodwin, "Pleasant Porter, 1840-1906," (master's thesis, University of Oklahoma, Norman, Oklahoma), 46-47, 141-143.

${ }^{89}$ Commission to the Five Civilized Tribes, Annual Report, Part II, Annual Reports of the Department of the Interior (Washington, D.C.: Government Printing office, 1902), 11; Grayson to Ryan, July 4, 1902, (1902) 4382, ITD.

90 Grayson to Ryan, July 4, 1902, (1902) 4382, ITD.

$91_{\text {Ibid. }}$

92 Wright to the, secretary of the Interior, July 31, 1902, (1902) 45887, ITD.

${ }^{93}$ Instructions to the Creek Appraisement Committee, September 20, 1902, (1902 7102, ITD.

${ }^{94}$ Grayson to Porter, November 5, 1902, 31200, CRN 37.

95 Muskogee Phoenix, January 17, 1901.

${ }^{96} \mathrm{~A}$ particularly interesting and sympathetic refutation of the criticisms of the Creek school system was written by Supervisor Alice Robertson, daughter of two generation of missionaries to the Indian 
Territory. "Report of Creek School Supervisor," Commissioner to the Five Civilized Tribes, Annual Report...1901, 306-313.

\section{Muskogee Phoenix, January 1, 1901.}

${ }^{98}$ okemah Independent, October $14,1904$.

${ }^{99}$ Their relationship was close enough that Grayson permitted Posey, unable to purchase a burial plot for his small daughter, to bury the child in the Grayson family plot in Greenwood Cemetery, Eufaula, Oklahoma. Interview of Mrs. Mildred Fuller Ewens, Eufaula, Oklahoma, October 13, 1988.

${ }^{100}$ Mrs. Minnie H. Posey, ed., Poems of Alexander Lawrence Posey, Creek Indian Bard (n.p.: Okmulgee Cultural Foundation and Five Civilized Tribes Heritage Foundation, 1969, revised edition), 17-33.

${ }^{101}$ Indian Journal (Eufaula and Muskogee, Creek Nation), June 26, 1903.

${ }^{102}$ Angie Debo noted that the final rolls of the Creek Nation, nearly completed in 1907, listed 11,952 creeks by blood and 6,809 freedmen. Angie Debo, And Still the Waters Run: The Betrayal of the five Civilized Tribes (Norman: University of Oklahoma, 1940, paperback edition, 1989), 47; Goodwin, "Pleasant Porter, Tribal Statesman," 162-163.

${ }^{103}$ Indian Journal (Eufaula and Muskogee, Creek Nation), June 29, 1903, quoted in Goodwin, "Pleasant Porter, Tribal Statesman," 164. 
${ }^{104}$ Chelsea Commercial, March 14, 1905.

${ }^{105}$ Holdenville Times, July 20, 1905.

${ }^{106}$ The primary work on the Sequoyah Constitutional Convention is by Amos D. Maxwell, The Sequoyah Constitutional Convention (Boston: Meador Publishing Company, 1953.

107 "To the Muskogee People," an open letter by Grayson and Porter, February 20, 1906, VI-16, Grayson Family Collection.

${ }^{108}$ Baird, ed., A Creek Warrior, 163-164. 
CHAPTER VII

"FALLEN TO THE MERCY OF OTHER POWER"

According to Creek tradition, a man passed through four stages of life. In the spring of his life, he received his infant's name and his education. As a young man in the summer of his life, he acquired his war name, hunted, and fought his nation's enemies. He became a leader, an advisor, or perhaps a spokesman for his people in the autumn of his life. He spent his winter years in his town, passing on in his turn to the younger generation the wisdom and history of his ancestors. Into his sixties George Washington Grayson followed this customary pattern; a self-taught scholar, he began to write the history of the Muskogees and an autobiography describing his role in it. But the unfinished business of the Creek nation, his detailed knowledge of it, and his concern for the conservation of the Creek national estate prevented his ever laying aside his official work for the pleasures of his avocation and the completion of the traditional cycle. 1

The evening before the last Creek Council convened in March 1906, Chief Pleasant Porter meditated on the transient nature of all peoples. He compared the decay of the Creek Nation to that of its shabby, deteriorating Capitol and told a visiting journalist, "My nation is about to disappear." 2 This was true to a certain extent. Federal bureaucrats now handled Creek finances and schools. The Council met 
only with the consent of the Department of the Interior. The chieftaincy was void of any real authority; and the executive office, located in rented quarters in Muskogee, operated as a branch office of the Bureau of Indian Affairs. 3

But in another way Chief Porter was wrong. The formal dissolution of the national government mandated by the Creek Agreement of 1901 did not mean that the Creeks disappeared as a people. That agreement made them American citizens; but many, including Grayson, retained their identity and continued to speak, live, and think of themselves as Creeks. Moreover, the unfinished business associated with the dissolution of the nation--equalization of and restriction on allotments and the liquidation of remaining Creek national assets--required the chief to retain his office and the Council to stand ready to convene as necessary. Because settling the affairs of the nation took several years and often involved negotiations in Washington, Grayson continued to serve as a representative of Creek interests. In fact, he did not attend that historic final session of the Creek Council. At Porter's request he remained on duty in Washington until the end of March 1906, once again the solitary rear guard watching the sun descend on his nation. 4

A number of issues concerned the Creeks, their chief, and Grayson; but Creek ownership of the land absorbed most of their attention. By 1906 allotment was nearly complete, and most allottees had received their patents. The emphasis now was on protecting ownership of the individual's land and recovering fraudulent and duplicate allotments. The discovery of the rich Glenn Pool near the old Creek town of Tulsa in 
1905 stimulated oil exploration and increased pressure on Creek allottees to sell or lease their lands. According to the Creek agreements, the Interior Department retained authority over all leasing of allotments. Oil men complained loudly about the bureaucratic red tape that hindered their exploitation of Creek lands. Another provision allowed allottees to sell all except a forty-acre homestead after five years or even before with the consent of the secretary of the Interior. By 1906 long lists of newly eligible creek sellers appeared weekly in territorial newspapers. Chief Porter now understood as Grayson did that naive Creeks were rapidly losing their land and mineral wealth through unwise business transactions. 5

Grayson had already taken advantage of the law that allowed him to apply for the lifting of the five-year restriction. The standardized form required the applicant to demonstrate his competence to manage property. As of July 14, 1905 Grayson described himself as sixty-two years old and a Creek citizen of one-quarter blood. Having attended school for four years, he spoke and read Creek and English. Once one of the most prosperous men in his nation, he stated that he presently owned only a span of horses, twelve hogs, and no agricultural implements. He had eighty acres of his allotment under cultivation by sharecroppers with the approval of the Department of the Interior. As evidence of his competence, he noted his tenure as National Treasurer for eight years and his career as a merchant in Eufaula for three years. In those positions he had handled as much as $\$ 90,000$ in cash. Grayson explained that he had no plans to sell but merely wanted his lands unencumbered by Federal control should he care to dispose of them. Two Federal offi- 
cials, one of them Union Agent Dana H. Kelsey, endorsed his application and described Grayson as a progressive businessman and prominent citizen of the Creek Nation. 6

Grayson's application was inconsistent with his account of his ancestry if he claimed to be one-quarter rather than half creek. This was perhaps an attempt to take advantage of the Interior Department's perception of Indians and resulting restriction policy: The less Indian "blood" a person possessed, the more likely he was to be competent to manage his business affairs. Many observers equated the adjectives "full-blood" and "ignorant," "mixed-blood" and "educated." Restriction according to blood quantum was a well-intentioned policy but did not always reflect the Creek (or any) population accurately. Still, if Grayson wanted to hasten the lifting of the restrictions on his surplus lands, the department was more likely to grant his request if he took advantage of his "white" blood. 7

Although Grayson was quite competent to manage his own affairs, he recognized the vulnerability of many of his fellow Creeks to exploitation by "grafters"--leasing agents, oil prospectors, real estate dealers, attorneys, more than a few Federal officials, and even some Creeks battening on fellow Creeks. By 1906 a territorial newspaper reported that fifty dollars would buy bootleg copies of the supposedly inaccessible Dawes census rolls of the Creek and Seminole nations. Most real estate offices in the Indian Territory had up-to-date copies, which expedited identifying newly unrestricted creek allottees. This must have been especially galling to the Creek executive staff because the Union Agency repeatedly ignored their requests for a copy from which to 
learn the addresses of allottees. 8

To protect those Indians most likely to fall prey to the grafters, Grayson joined members of the Five Civilized Tribes in calling for an extension of the restrictions preventing the sale of Indian lands. While the 40-acre homestead of each allotment was inalienable and untaxable for twenty-one years, the surplus lands in each 120-acre allotment, many believed, should be unrestricted. Those most vocal in demanding the lifting of restrictions were the boomer element, oil men, and statehood proponents who realized that the prolonged nontaxable status of Indian land would hamper finances. 9

In November 1906 a senatorial investigating committee heard testimony in Muskogee on this and other topics. Witnesses aired a variety of views on the restrictions. Chitto Harjo, ignoring the finality of allotment, called for a return to the old days: "o give us the land in common that we may hunt at will, hunting the wild deer, turkey, or gather the wary fish from the dancing streams." 10 Equally unrealistically at the other extreme, Cherokee citizen Robert I. Owen supported lifting all restrictions, stating, "The wild Indian puts his child into swimming water and it swims. Individual responsibility, individual initiative, is absolutely essential to individual development."11 Former Creek chief Legus Perryman, now a Tulsa real estate dealer, echoed Owen's opinion. They probably represented the majority of mixed-bloods, who, now that allotment was forced on them, wanted complete control of their lands. Grayson fell into that category, but, with Creek national attorney M. L. Mott and interpreter David M. Hodge, he favored restrictions to protect the full-bloods, who were most 
vulnerable to the grafters. 12

The following September Chief Pleasant Porter died unexpectedly, and Second-Chief Moty Tiger succeeded him with the approval of the Secretary of the Interior. Tiger had a sound reputation among his fellow Creeks. About a year older than Grayson, he had fought with him in Chilly McIntosh's Confederate regiment. He was a former lighthorse captain, a Council member from conservative Tuckabatchee Town, Attorney General, superintendent of the Creek Orphan School, and a Methodist minister. Observers usually mistook Tiger for a full-blood although he was actually one-quarter white. He and Grayson had much in common, including their realistic perception of Creek affairs and conservative goals. ${ }^{13}$

Grayson recalled one version of that visit of the Dawes Commission to Okmulgee in April 1894 as an illustration of Tiger's farsightedness and moral courage. When the commissioners finished their argument in favor of allotment and statehood, they asked all who opposed them to step to the right. Out of the crowd of three thousand Creeks, Tiger, "true to his convictions, solitary and alone, deliberately crossed over the walk, the only one in that vast gathering of the creeks who was favorable to the land policy outlined for the Indians by the government." Most Creeks regarded his,action as treason; but, Grayson concluded, Tiger saw the new policy as unavoidable and believed it his duty to. say so: A "wave of white settlers would soon ruin [the] Indian Nations as independent; he maintained that the tribesmen needed what protection the U.S. could offer." 14

It was that protection Chief Tiger sought in November $1907^{4}$ from 
Congress and the Secretary of the Interior. Grayson, Samuel J. Haynes, and Johnson E. Tiger, Moty's son, accompanied him as delegates. With national attorney M. L. Mott, they set up a temporary headquarters of the Creek nation the National Hotel. Chief Tiger was literate but not fluent in English; Grayson doubled as his interpreter. The Tigers, father and son, and Haynes, a full-blood, perhaps demonstrated the conservative dominance of the Council that developed as mixed-bloods looked to their individual interests. That Grayson accompanied them was perhaps indicative of his growing conservatism. If so, it put him at odds with the many mixed-bloods who now accepted the boomer and Federal attitude toward developing the Indian Territory. 15

The delegation went to the capital with instructions from the Creek Council to oppose the removal of restrictions from the forty-acre homesteads. Grayson realized that they faced opposition from two sources: A number of white men from the territory were in town also, and they strongly advocated the removal of restrictions. At the same time, Chitto Harjo and a party of traditionalists were in Washington pleading their own cause. While the former group could expect a warm welcome, the snake delegates, Grayson supposed, would "push their claims for a restoration of our old laws under treaties now obsolete and dead" with "no possible show for success." Even so, Grayson was optimistic that the official delegation would succeed in maintaining the restrictions. On December 3 they called on President Theodore Roosevelt; he listened sympathetically and assured them of his support. Grayson believed legislation on restrictions would pass that session of Congress. "Whatever is done," he wrote, "we hope to exert such an in- 
fluence as to prevent its provisions from swallowing up and rendering

our citizens, freedmen as well as Indians, homeless." 16

Two months later the delegates appeared before the House Committee on Indian Affairs as it considered legislation on allotment restrictions. Grayson interpreted as Chief Tiger reminded the Congressmen that the Federal Government had set itself up as the protector of the Indian: "I look upon you very much as the Great Spirit, with his great power. If he were to withhold his power and mercy you would be destroyed."17 So would the Creeks be destroyed if the protective restrictions were removed. Tiger understood that the sentiment for removal of restrictions on mixed-bloods was very strong, but he believed an infusion of white or other blood did not protect them from the rapacity of the whites. If the restrictions were removed, Tiger solemnly warned: there are persons here in this city who will touch the wires all over this town, and the information will be down there in our country in a moment's time, and the people who are down there ready to rob our people, as it may be said, would have the lands already signed away to them in a few hours' time. 18 The Congressmen, including Bird S. McGuire of Oklahoma, questioned whether Tiger and the delegation represented the real sentiments of Creek people. They reminded Tiger that he had not, after all, been elected chief but had merely succeeded Porter. Tiger replied dryly that he was chief as surely as Roosevelt was president. Furthermore, he and the delegation reflected the majority opinion among Creeks because they spoke for the creek Council: It had thoroughly considered the matter in August 1907 and ordered them to oppose the removal of restrictions. ${ }^{19}$ To summarize their argument, the Creek delegation presented a letter very much in Grayson's prose style. Creeks, they explained, 
viewed land as they did "the other cardinal elements of water, air, light, and sunshine, something spontaneous and ever existing, which has been beneficently provided by the Great spirit for the free use and support of all His children and not a thing on which a money valuation may be placed." But the government forced allotment on them in spite of decades of resistance. "The Creeks have not forgotten their sad experience of a few generations ago in the states of Georgia and Alabama, their former homes, where were practiced almost identically the same things we see now occurring in the state of Oklahoma." 20 The delegates explained how grafters used fraud, intimidation, extortion, and even abduction to gain control of the lands of ignorant Creeks who did not understand the legal system. Because so many lawyers were involved in grafting, Creeks had no real recourse through the Oklahoma court system. In fact, the delegates asked that Indians be exempt from it in any land case. $^{21}$

The delegates declared again that an infusion of white blood did not make a creek competent in business. They requested that homesteads of all Creeks remain restricted except with the approval of the Department of the Interior. The delegates concluded:

Once a great and noble people, friendly and hospitable to the visiting stranger, our race is run, our sun is set. You have no more great outlying west to which you may push us, as you formerly did, with the assurance that there we may live and prosper "as long as grass grows and water flows," and we beg of you to stamp out the practice of greed and avarice prevailing in our country until our citizens reach that advancement that will enable them with advantage to themselves to assume the full stature of American citizenship with all of its attendant advantages and responsibilities. 22

The delegates were only partially successful in their attempt to conserve remaining Creek lands. In May 1908 Congress lifted restric- 
tions on all intermarried whites, freedmen, and mixed-bloods less than half-blood Indian. Restrictions continued on the homesteads of mixedbloods more than one-half Indian and on all the land of full-bloods until April 26, 1931 except with departmental approval. This legislation attempted to right wrongs by invalidating the deeds, contracts, mortgages, and powers of attorney made prior to the removal of restrictions. It provided funds for suits to recover the rights of the original allottees, and Mott vigorously set about filing those suits. But the act also handed over such cases and the affairs of Indian minors to the Oklahoma court system. According to one historian, more than twelve million acres of Indian land became immediately available for sale and taxation, prompting a week-long celebration in Muskogee. ${ }^{23}$ Creeks and other Indians found themselves under the control of a "vast criminal conspiracy" intent on looting their domain. ${ }^{24}$

Another concern of the Creek delegation was continuing the national government. In the absence of real power or election machinery to replace aging or deceased members, other tribal legislatures gradually atrophied. But, as it became clear that the affairs of the Creek nation could not be concluded before March 4, 1906, the mandated dissolution date, the Creek Council petitioned the secretary of the Interior for permission to continue its annual sessions. In January 1908 Grayson forwarded a request for a Council because it served as a clearinghouse for information now that there was no longer a native press such as the Indian Journal. Even occasional sessions of the Council and the continuing needs could not revitalize the Creek national government, and it dwindled slowly until it consisted of only the chief, the national 
attorney, and the executive office staff. Except in the case of the attorney, they had little to do except distribute allotment patents and sign warrants while the Federal Government liquidated their few remaining national assets. 25

Another concern of the Creek executive office and delegation was the fate of their national funds. According to the curtis Act, the Department of the Interior received and disbursed all Creek revenues. Grayson's old office of National Treasurer ceased to exist. Unfortunately the Federal officials who took over that function spent Creek funds freely with little attempt to keep accurate accounts. As early as 1905 Creeks questioned the handling of their money. Late that year Grayson asked for an official statement of the amount of creek funds in the Federal Treasury, the royalties and monies raised by the sale of town lots, taxes and names of taxpayers by quarter, and the disbursements of Creek monies. It was a reasonable request creeks made often over the next several years but one the Federal bureaucracy generally ignored. 26

On one occasion Grayson lost his patience with the lack of information provided on the handling of Creek funds. He reminded the Commissioner of Indian Affairs that the Creeks were a class above the "blanket Indians" needing constant oversight; they were, rather, "sufficiently advanced in civilization to intelligently negotiate important treaties and agreements with the United States and be held reasonable parties." To withhold information on "transactions involving large amounts of their moneys, without consulting them, [was], to say the least, irregular and not in accordance with the usages governing in ordinary 
civilized methods of business." 27

In 1906 Grayson questioned disbursements for roads, Indian depredations, guards, clerks, and office equipment, but especially $\$ 18,735$ for suppression of smallpox. The Creeks never requested this type of aid, he stated. It was merely a pork barrel project designed to provide lucrative employment for a few non-citizens. Grayson demanded futilely that the Indian Department ask Congress for an appropriation of $\$ 83,7525$ to repay the Creeks for such questionable expenditures. ${ }^{28}$ Even this amount was small compared to the extravagant sums spent yearly on creek schools under Federal administration. The education budget doubled the first year Federal administrators took charge. Eventually, the Department of the Interior set a very generous annual limit of $\$ 105,493$, well over the $\$ 76,468$ the Creeks spent the last year they controlled their funds. These expenditures combined with losses on the mismanaged sale of town lots, oil royalties, unallotted lands, and other items became increasingly important as Creeks contemplated the major residual problem. It was one to which Grayson gave much attention following the dissolution of the Creek nation, the equalization of allotments. 29 According to the Creek Agreement of 1901, each citizen was to receive 160 acres. If the value of his lands was less than $\$ 1,040$, he was to receive the difference in land or cash once allotment and the liquidation of Creek national assets were complete. This $\$ 1,040$ was each Creek's share of his national estate. Toward this end the Dawes Commission prepared census rolls of all Creek citizens as of May 25, 1901, the date of the agreement, listing 15,784 citizens including freedmen. In November 1904 the Creek Council, believing there would be 
a surplus of half a million acres, passed a resolution asking that all Creek children born up until March 4, 1906 be added to the rolls. Creek officials never formally forwarded the resolution. The delegates apparently passed the request directly to Congress without going through the usual channels. Subsequently, the Department of the Interior added 1,782 Creek newborns and 1,136 freedmen newborns to the Dawes rolls. As of August $1907 \mathrm{~J}$. George Wright, the Commissioner to the Five Civilized Tribes, reported that 17,924 of the 18,698 Creeks on the rolls had received allotments valued on the average at $\$ 661.75$. More than two hundred thousand acres remained to be allotted. When the process was complete, $\$ 6,700,000$ of Creek funds should remain for the equalization of allotments. 30

Even in 1907 the process seemed to the Creeks to be taking too long. Many were land poor and needed the anticipated cash payment. In February 1907 Chief Porter, Grayson, and Samuel J. Haynes told the Commissioner of Indian Affairs they saw no reason why equalization of allotments should not take place at once. They believed it would "provide nearly all adults...sufficient and ready means with which to improve their allotments, thus obviating the necessity of selling land." At the same time it would terminate their position "as wards of the government, which under all circumstances is the most desirable thing to accomplish." 31

But by summer the termination of equalization seemed as far away as ever. Creeks grew impatient, and that impatience was tinged with alarm as they became aware of the ease with which their national treasure was flowing through the fingers of the Federal administrators. In August 
1907 the Creek Council called on the Federal Government to settle its affairs as quickly as possible, to discard equalization, and instead to disburse the remaining Creek funds on a per capita basis. Commissioner Wright, however, rejected this as impractical because allotment was not yet complete; and the Commissioner of Indian Affairs agreed with him. ${ }^{32}$ In January 1908 Grayson, Chief Tiger, Johnson E. Tiger, and Haynes pursued the Council's request in Washington. They told Secretary James R. Garfield they were now aware that there would be a shortfall precluding equalization as stipulated in the Creek Agreement, and the passage of time would only increase the deficit. They admitted that a per capita distribution of remaining Creek funds would not be fair to all, but it would "for a considerable time remove from our people the temptations to yield to the blandishments of the unscrupulous land grafter, and quiet the voice of complaint now so rife throughout our country."33 But Grayson was disappointed when another spring session of Congress passed without per capita distribution being incorporated in the latest Indian Appropriations bill. The Federal Government, it appeared, was determined to adhere to the policy of equalization even if it dragged on for several years. 34

Having now no control over the expenditure of their own funds, Creek officials, in the meantime, tried to find ways to alleviate the shortfall. Grayson in May 1908 asked information concerning the survey of the Creek-Seminole boundary, pursuing possible compensation for seven thousand acres of Creek lands awarded to the Seminoles through a survey error. Chief Tiger strove to cut the expenses of running the executive office by dispensing with the usual delegations to Congress. Instead, 
he left communications with Washington to M. L. Mott, the Creek national attorney. Mott, with the backing of the Creek council, in 1907 filed a number of suits to recover losses from the fraudulent sale of town lots, winning back eventually slightly more than the $\$ 101,000$ the suits cost the creeks. The most popular tactic was to charge that the Dawes Commission had inflated the Creek rolls by adding the newborns of the 1901-1906 period. On November 25, 1908 the Creek Council passed a resolution to this effect. It asked that congress appropriate four million dollars to pay the resulting difference needed to equalize allotments as well as to compensate for land taken from the creeks in the incorrect boundary survey. 35

The Department of the Interior received this gambit coolly, while Congress insisted on equalization. On March 3, 1909 Congress passed an act to pay each creek allottee $\$ 800$ provided this settlement was final and conclusive. Chief Tiger called a special session of the Creek Council to consider the act, but he made it quite clear that he opposed accepting anything less than $\$ 1,040$ per allottee. The House of Kings unanimously rejected the act; the House of Warriors defeated it fifty to seven. It is impossible now to determine how Grayson voted, but his close association with Chief Tiger and subsequent comments indicate that he supported the chief's hard line position. 36

The problem of equalization dragged on through the rest of 1909 and 1910. Tiger and Mott (undoubtedly with Grayson interpreting) appeared before Assistant Secretary Frank Pierce in February 1910 to state the case of the Creek Nation. They insisted that the fault of the shortage lay with the Dawes Commission. Tiger charged that Federal bureaucrats 
repeatedly denied the creek chief and national attorney access to the Dawes census rolls. Consequently, they did not know until late 1907 that inclusion of the newborns exceeded the resources of the nation. Furthermore, Chief Porter never signed the resolution whereby the newborns were added to the rolls; it was found among his papers after his death. 37

Mott followed the same line of reasoning and added an ulterior motive for the addition of the newborns. Tams Bixby, Chairman of the Dawes Commission, was "wholly responsible for this policy" and the Department agreed to it on his recommendation. "The only result from it...was to give an opportunity for a select coterie of traders who had access to this information to speculate in Freedmen lands without any competition, which speculation included much lands with valuable mineral deposits." Referring to the act of 1909 that offered each Creek allottee only $\$ 800$ from Creek funds, Mott concluded, "This Act of Congress...proposed to give the Indian what is already his on a condition that he relinquish something else which he is entitled to." 38 Neither argument carried any weight with Congress or the Department. Through 1911 and 1912 Senator Robert L. Owen and Congressman James S. Davenport of Oklahoma offered numerous bills (many by request) offering various amounts in equalization with optional referral to the Court of Claims. None passed. Meanwhile, Creeks became ever more restless and discontented. Chief Tiger in an attempt to trim national expenses refused to appropriate the $\$ 25,000$ necessary to fund a session of the Council from 1909 to 1912, but in so doing he eliminated that tie between the Creeks and their executive and deprived them of their usual 
forum. It was not surprising, then, that a mass meeting of Creeks at Okmulgee in the summer of 1912 generated a petition that complained of the lack of a Council session at which they could learn what Congress was doing, of a chief they had not elected, and at the lack of action in concluding their affairs. 39

For all his economies, Chief Tiger refused to sacrifice one staff position, that of Grayson as executive interpreter. Questioned as to the necessity of this expense, Tiger replied that he had need of an interpreter "whose thorough competence and reliability is such as is not easily to be had except for liberal pay." Grayson served as his private secretary, ran the executive office when Tiger was ill, and translated his official correspondence because of Tiger's "very imperfect knowledge" 40 of English. For this he received $\$ 125$ per month and paid his own expenses for board, lodging, and travel. Consequently, when Tiger went to Washington for the fall session of Congress in 1912, he took Grayson with him in the triple role of interpreter, private secretary, and unofficial delegate. 41

The 1912 Congressional term was no more productive than earlier sessions as far as the Creeks were concerned. Petitions came from dissident Creeks with the suggestion that Chief Tiger's lack of English kept him from fulfilling his responsibilities. They suggested that he be replaced. There were also white complaints against Creek attorney Mott, whose energetic campaign through the court system against grafters offended many influential people in eastern Oklahoma. In spite of Chief Tiger's protests on his behalf, when Mott's contract with the Creeks expired in January 1914, Secretary of the Interior Franklin K. Lane 
refused to renew it. On Mott's recommendation, Richard C. Allen replaced him as Creek attorney. 42

Tiger and Grayson, who stayed in Washington to stand by Mott in his defense of his position before the Secretary, made it clear to Allen that they gave the equalization issue top priority. At some point over the last several months, someone had suggested that by excluding the freedmen from equalization enough money would remain to compensate other Creek citizens in full. Tiger and Grayson wanted Allen to pursue this option and insist the Federal Government adhere to the agreement of 1898 with the Dawes Commission. Section 24 stated that each freedman should receive 160 acres but no equalization money. The Creeks, they told Allen, wanted to have a Council session to discuss this option. Because there was no money to do so, the executive office mailed a ballot to each Council member asking, "Do you want the freedmen members of the tribe to share in equalization money now in the treasury?" Whatever the result of the poll, Federal officials quickly squelched it on the grounds that the Reconstruction Treaty of 1866 was quite clear on the equal rights of freedmen, since reinforced in a supreme court decision, Whitmire, Trustee v. Cherokee Nation. 43

This was apparently their last ploy. In 1914 Congress finally attached a provision to the annual Indian appropriation act for the equalization of Creek allotments with $\$ 800$ as the standard. The Union Agent reckoned that eligible Creeks, mostly full-bloods and freedmen, were due $\$ 1,824,284$ with payment to begin september 1 . Allen wisely recommended that officials pay only a small deposit, particularly to Creeks living outside Muskogee County, and hold the balance; otherwise, 
they would probably spend the whole amount before they reached home.44 The department attempted to protect restricted Creeks by ruling their equalization money exempt from attorneys' fees, creditors, and checkcashing fees. But it was now nearly a decade since the whole process began. Many recipients no longer lived at their Dawes rolls addresses and could not be located; others were dead and beyond any benefit of the payment. 45

It was perhaps just as well that this last major issue of the national dissolution period was resolved, because by 1914 Chief Tiger's days of effective leadership were over. Like Grayson, he was well into his seventies. But while Grayson was still as mentally vigorous and competent as ever, Tiger was, according to many critics, "superannuated." 46 Former Creek attorney Mott was a close associate for years, testified, "In the matter of integrity and truth, I regard him as a man above reproach. He is of a gentle character, sympathetic, responsive to appeals; and he is timid in the matters of turmoil and strife, likes to avoid them." 47 This he said of the man willing to cast the single assenting vote on allotment in 1894. By 1914 the elderly chief, always dependent on Grayson because of his lack of English, was vulnerable to contending forces and demands beyond his present understanding. Nothing was more indicative of this than the Richard C. Allen affair of 1915. Allen was typical of the ambitious young men who came to the new state of Oklahoma to make their fortunes. Originally from North Carolina, he began practicing law in 1902 in Coweta, Creek Nation. In 1910, the young Democrat was elected judge of the Third Judicial District, comprising Muskogee and Wagoner counties. But Allen was also 
a member of the Coweta Realty Company and an acknowledged grafter named in seventy-three suits involving Creek lands. Grafting was not necessarily regarded as an evil in oklahoma during that first tumultuous decade, but Allen's involvement in the Martha Verner McKinley incident was particularly scandalous. Knowing that restricted minors automatically received title to their surplus lands when they married, Allen supplied a groom and a license, arranged for fifteen-year-old Martha's elopement, provided a forged parental permission for the marriage ceremony, and then promptly bought her eighty-acre surplus for a small fraction of its considerable value. Unfortunately, this case was typical of the times, and it was exactly what Grayson had hoped to prevent in fighting to maintain restrictions. 48

In spite of Allen's blemished past, Mott recommended him for Creek attorney; the Department of the Interior and President Woodrow Wilson approved Allen's contract. Through the first year of his tenure he energetically worked through the probate courts to correct some of the abuses he had committed earlier. In so doing, he, like Mott, made some powerful enemies in eastern oklahoma. 49 His contract came up for renewal in the spring of 1915 about the same time simmering discontent among Creeks intensified. Whereas more acculturated mixed-bloods were prepared to blend into white society and institutions, the less acculturated, particularly the full-bloods, felt they had no access to Oklahoma's social and political structure. For nearly a decade Federal Indian policy had denied these Creeks the choice of their own leaders, the forum of their Council, control over their affairs, and the direct communication of their delegates with Washington to which they were 
accustomed. They were ripe for the manipulation of Allen's enemies. According to Grayson, he was in the Creek executive office in Muskogee when Allen in April 1915 presented Chief Tiger the document renewing his contract. It was nearly three months early, but Allen said he wanted to adjust his work schedule accordingly. Tiger hesitated and asked Grayson his opinion; but the latter, perhaps because of Allen's controversial reputation, refused to advise him on the renewal. They dropped the matter for about ten days until Allen again presented Tiger his contract. Grayson and the chief then sat privately at a table with Grayson translating a few lines at a time until they worked through the whole document. Grayson noted Tiger's objections on a separate sheet, and when they were finished Tiger discussed and worked out his concerns with Allen. Still, Grayson insisted, he refused to comment on the contract even to former attorney Mott. "I told him I was not going to give any advice; that the Chief would have to do his own work. "50 Grayson was stunned on his next visit to the Creek executive office in Muskogee to hear from Allen that Tiger had rejected the contract in a telegram and letter to the Department of the Interior. Tiger explained to Grayson that David M. Hodge and $S$. W. Brown told him of a proposed mass meeting at which Creeks planned to protest Allen's work and reappointment. They supplied the letter and telegram rejecting the contract that he signed. Allen, Tiger, and Grayson discussed the situation and the attorney's pending cases before again agreeing on the contract. At Tiger's request Grayson wrote yet another telegram and letter in Allen's favor and sent them off to the department. Grayson thought the matter was finished, but two weeks later Chief Tiger again canceled the con- 
tract. 51

While the chief vacillated, a flurry of telegrams arrived at the Department of the Interior. All contained basically the same wording, all were sent on April 28 or 29 in the early hours of the morning, and all carried the same message: Chief Tiger was too hasty; delay Allen's reappointment until you hear from us. All purported to be from fullblood Creeks. One, Billie Bruner, a former member of the House of Kings fluent in English and Muskogee, later inquired of Commissioner Cato Sells why his office acknowledged a telegram he never sent. 52

Two weeks later with the Allen issue still unresolved, Sarty Cowe, a full-blood, called a mass meeting, the only forum left, of those dissatisfied with the equalization settlement. But at the meeting on May 12 the discussion focused on the Allen reappointment, criticism of Chief Tiger, and his possible replacement. A protest against Allen's reappointment and a petition demanding an investigation of his work circulated through the crowd. Later several signers, including Cowe, denied that they had ever endorsed more than a call for an investigation. On May 21 letters from a number of leading Creeks and former Council members--Timmie Fife, G. W. Stidham Jr., Cheesie McIntosh, George M. Carr, William McCombs, Grayson, and Billie Bruner--expressed complete confidence in Allen and his ability to withstand an investigation. They discounted the recent petition and suggested that the whole controversy was the work of oil men whom Allen's suits threatened. 53

At the end of May the understandably confused Bureau of Indian Affairs dispatched Chief Inspector E. B. Linnen to investigate the chaotic situation in oklahoma. Linnen proved to be less than objective. 
His findings on Allen's earlier career as a grafter probably led him to expect the worst from Allen supporters, including Grayson. On May 27 he called together in Tulsa Tiger, Hodge, Brown, Mott, and a handful of others. Notably absent was Tiger's usual interpreter, G. W. Grayson. Hodge, an Allen opponent and author of the first rejection letter, presumably translated. Tiger told Linnen "he was induced and prevailed upon by Captain G. W. Grayson" to execute Allen's contract. He revoked it after hearing objections to Allen. At a later meeting in Muskogee with Grayson and a number of other prominent Creeks, he was again "induced and prevailed upon by Captain G. W. Grayson principally" 54 and Allen to withdraw his rejection. Otherwise, they told him, the Department would lose confidence in him and Allen would be appointed any way. Tiger said he signed against his best judgment. 55

Iinnen also took testimony from Allen. The attorney defended his early land deals as common practice in eastern Oklahoma. He attributed the resistance to his reappointment to several wealthy and influential men in the oil and gas business--Tulsa oil baron and philanthropist Charles Page, his partner R. H. Josey of Prague, Oklahoma, O. A. Morton, Will Morton, and Walter Morton, merchants and professional guardians of Creek minors. 56 One of Allen's defenders clarified the roles of these men in the murky business climate of the former Creek Nation. Page and Josey were involved in the Creeks' attempt to recover the oil-rich and completely spurious Tommy Atkins allotment. The Creeks lost, but the implications of the litigation so embarrassed Page and Josey that Page stated before witnesses his intent "to get Allen's scalp." Josey declared he was willing to pay to see Allen ousted. Josey and H. C. 
Walkley, a Page employee and "grafting Cherokee," circulated the questionable petition at the mass meeting of May 12.57

Allen made another enemy in suing for the recovery of the Katie Fixico allotment from 0. A. Morton. Morton paid \$2,200 dollars for it. The land lay in the Cushing Oil Field, was producing eight thousand barrels a day, and was worth half a million dollars. "Is it any wonder that Page, Josey, and the Mortons desire Allen's re- moval?"58 an Allen defender asked. If he were removed, who would replace him to continue the suits? Billie Bruner, a somewhat less biased observer, summarized the situation in a letter to Commissioner sells: Allen had incurred the anger of "the grafters and the land-grabbers who infest this country, among whom are many white men, some so-called prominent Indians, and in some instances, some of the courts, or Judges of Courts."59

But Iinnen seemed less interested in these allegations than in exploring the relationship of Allen, Mott, and Grayson to Chief Tiger. On May 31, before he took testimony from Mott and Grayson, the investigator wired sells that he had talked with Chief Tiger, Hodge, and Brown. The chief "tells of wrong influence used to send that telegram which Grayson wrote for Allen. I have the facts correctly on all these matters." 60

On June 7 Linnen took affidavits from Grayson and former Creek attorney Mott. The line of questioning made it quite clear that he believed these men and Allen exercised undue influence over the elderly chief. Linnen implied no purpose for that influence in the case of the two attorneys, but the motive he attributed to Grayson was quite clear: he wished to be chief and needed Allen's support to win approval from 
the Department of the Interior. Linnen's first question of substance to Mott dealt with Tiger's views on retirement and a possible successor. Tiger told him last winter in Washington, Mott testified, that he was considering retirement because of his fading vision:

The Chief and I both through my service have relied on Captain Grayson, especially the Chief, having more confidence in him than any other member of the Tribe, and I think properly so, have thought so, but later he changed his mind about resigning I suppose.... I suggested... Captain Grayson would make a good chief for the tribe." 61

Mott mentioned this to Allen, who also agreed that Grayson would be a good and deserving choice. But, Mott supposed, Tiger now favored his son, Johnson, if he intended to retire at all. 62

Linnen took the same line of questioning with Grayson. He pointed out that Tiger was old and feeble and asked if Grayson had aspirations to succeed him. Grayson denied that ambition and that he had ever proposed himself to the chief as his successor. Nor had he discussed the matter with Allen. But he had told Mott, "I would like it very well."63 He supposed Allen would support him should the occasion arise. On the second day of testimony, Linnen was more specific. "Is it not a fact that Mr. Mott told you that Attorney Allen had said that he, Allen, would hold up Chief Tiger's resignation and not present it to the Secretary of the Interior unless the Secretary was in favor of appointing you Chief?" Grayson answered no. He agreed that Chief Tiger was easily influenced and that he could usually sway him. Grayson also denied knowledge of Allen's land deals or his present suits. ${ }^{64}$

Grayson did admit that he had expressed to Commissioner sells his concern over the petitions circulating among the Creeks. These were typewritten papers containing statements naive Creeks accepted as facts. 
Outsiders also hired Indians to solicit signatures, and Creeks who knew no better signed petitions to oblige them. Grayson could name no names, but he believed grafters were after Allen. He concluded, "The air, it may be said, is almost saturated with a report; if that can be called gossip, why then this must be gossip." 65

Again Linnen abandoned the topic of Allen to return to Grayson's ambitions. Grayson's testimony agreed with Mott's. Any discussion of his succeeding Tiger was quite casual. "There was something said that if the old gentleman would resign I might take his place. As I said before, that would be all right with me, but I have never done anything or had any extended conversation with anyone on the subject and never have thought much about it."66 If Linnen was attempting to prove that Grayson was manipulating the old chief in collusion with Mott and Allen, he failed to do so. All three denied it; and other witnesses, none of whom were strictly unbiased, contributed little of substance. 67

Linnen's investigation was inconclusive, but it fueled the rumors circulating around Creek country. Public and private speculation was that Chief Tiger would soon resign and that Grayson would become chief. This provoked mass meetings in Muskogee and Wetumka. The Muskogee protesters, about half of them full-bloods, called for Tiger's resignation but split over support of Allen. ${ }^{68}$ The Wetumka meeting, organized by Sarty Cowe and largely full-blood, produced a letter to Commissioner Sells that demonstrated their sense of helplessness and abandonment. They understood the agitation as the "Half Breed and Oil people Element" attempting to replace Tiger with Grayson. They wanted Tiger removed; but, Cowe wrote: 
G. W. Grayson...has no real interest of the creek people and is some what too old in age. [We] wish to say that the Department is to day dealing with Full-Bloods as they have by legislature and rullings [sic] practicly [sic] has rulled [sic] out the Negroes and Half breeds but are still clinging to us Full Bloods and therefore we would like the privileges of nameing [ $\underline{\underline{i} i \underline{C}]}$ ] the best man who would have at heart the Full Bloods like us... we are fallen to the mercy of other power. 69

The uproar attracted Commissioner Sells's personal interest. On June 25 he ordered Tiger to come to Washington immediately; he insisted that Tiger bring Grayson as his interpreter. The problem, however, was in Grayson's locating Tiger. When Grayson arrived at the Muskogee office on June 23, he discovered S. W. Brown and Ben Grayson had the old man in their charge and that he was drunk. They induced the chief to sign an attorney's contract with Allen's rival, Judge Thomas Leahy, and then spirited him away to Tulsa. Grayson followed them there and found the whole group, now including Hodge, intoxicated. Grayson removed Tiger from their company, but on June 29 Secretary Lane ordered Grayson and Tiger to wait in oklahoma until summoned. $\mathbf{7 0}$

To complicate matters, telegrams in Tiger's name, sent June 25 when the old man was, according to his office, out of contact on his okmulgee farm, begged Senator Robert L. Owen and the Indian Rights Association to stop the Allen reappointment and to intercede with the Department of the Interior. ${ }^{71}$ The IRA in fact sent 5. M. Brosius to investigate. He talked to Chief Tiger and found him "clear headed and sober [which] set at rest some of the stories I had heard regarding his conditions and habits."72 But the interpreter during this visit was Sam Haynes, a leader of the anti-Allen faction. ${ }^{73}$ one might question whether Haynes interpreted the conversation without bias.

By the end of June the affair reached the oval office when Tiger 
(or someone claiming to be he) complained to President Wilson. Lane preferred to treat the matter lightly in response to Wilson's inquiry: "Moty Tiger... is not as anxious to see me as I am to see him. On Friday last I wired him to come here that we might consult, but he got drunk so that I have had to send a special officer to bring him here; expect him tomorrow unless the officer also gets drunk." Lane explained about the conflicting communications and put Tiger's erratic behavior down to senility. As for Allen, Lane wrote, "I think the chief trouble with him is that he has brilliant red hair and goes about things in a redheaded fashion, but I shall be careful in the matter."74

With Commissioner Sells out of town, Lane took over the investigation and summoned all parties concerned to Washington for a hearing on July 14. On the evening before their departure one of Allen's cronies overheard Hodge pressure Chief Tiger to use him rather than Grayson as his interpreter. Apparently Tiger agreed for the next day Linnen, Tiger, Grayson, and Hodge left for Washington on the Katy Flyer, probably a very uncomfortable group of traveling companions. 75

At the hearing on July 14 Allen acquitted himself well enough to persuade Lane to renew his contract, and Grayson returned home with the contract on its way to President Wilson for his signature. Even then the intrigue continued, for as late as July 28, Moty Tiger denied support of Allen. To Lane Tiger wrote, "Since my return from Washington, I have been told that Mr. Grayson, who interpreted for me before you, did not correctly state my remarks to you. At no time during our conference did I state that I favored R. C. Allen as Creek Attorney or desired his appointment." 76 
Out of this welter of charge, denial, countercharge, and retraction, one can draw some conclusions. Sadly, Chief Moty Tiger had lived beyond his usefulness to his people. His moral courage and judgment had weathered away, leaving a confused and vulnerable old man. Allen's enemies used his bewilderment to undermine the Creek attorney. But it is also probable that Inspector Iinnen was correct: Mott, Allen, and Grayson were influencing the chief's decisions.

Those decisions, however, no longer carried the import they had even in Porter's day. Tiger presided over the remaining Creek national estate: as of 1916, this consisted of the Council House in Okmulgee, 2,495 acres of unallotted land, 168 town lots, and four boarding schools. Unfinished business included 450 undelivered allotment patents, continuing payment of equalization money, and cases of fraudulent or duplicate allotment that might yet yield revenue to the Creeks. The real work of the executive office fell to the attorney as he contended with these matters and the grafters. 77 Although Grayson once aspired to be chief, the title was now more honorary than real. He probably did not covet Tiger's position in 1915 as he had Porter's in 1903; and at seventy-two could not realistically expect to succeed him.

Tiger's growing incompetence was not a problem under normal circumstances. The Federal Government had assumed the major responsibilities of the Creek national government in 1906. Allen performed his work energetically if not always productively. Mott was still an informal and benevolent advisor. Grayson was there to lead Tiger through the smaller tasks and to handle his official correspondence, perhaps out of the genuine respect he had for the man Moty Tiger had been. The short- 
coming in this system was the failure of the executive to maintain contact with his scattered people and to reassure them that he could still guard their interests. Perhaps these functions were beyond the power of any chief by 1915 .

Problems arose when the machinations of Allen's enemies--the false petitions, the protests, the forged telegrams, and the rumors--exacerbated the discontent of the full-blood Creeks. At the same time, the importunity of Allen's enemies and the attempts of Grayson, Mott, and Allen to keep the old man in line with the will of the Federal Government exposed him as gullible and ineffective. Had there been a real need for competency in the office at this time, this controversy must surely have resulted in Tiger's removal from office.

But Moty Tiger, incompetent or not, was allowed to keep his office for two more years. This suggests, first, that the chieftaincy was so empty of consequence that the Department of the Interior saw no reason to fill it with a more responsible man. Secondly, although Allen's reappointment was important enough to some eastern oklahomans to drive them to forgery and conspiracy, the Department of the Interior paid little genuine attention to their vehement protests. In fact, the Department never made public the findings of Inspector Linnen's investigation and refused to answer Congressman Davenport's inquiries concerning it. This may have been because Allen was on the surface satisfying the critics' demand for prosecution of the grafters. It may also have been because he was, after all, a loyal Democrat in a Democratic administration. On the other hand, it demonstrated considerable tolerance toward a man of questionable integrity. Everyone involved, includ- 
ing Grayson in spite of his denials, must have known of Allen's career as a grafter. Yet the department, over continuing Creek protests, approved his contract not only in 1914 but in 1915 and 1916 as well. If nothing else, this demonstrated once again the Federal Government's decades-old lack of concern for the sincere opposition of the Creeks to its policies. ${ }^{78}$

Lastly, the retention of Tiger as chief suggests that the department was well aware that it was not he but Grayson who handled matters in the Muskogee office. Sells insisted on June 25 that Grayson come with the chief to Washington, not that the chief come with an interpreter. And whatever Tiger's wish, it was Grayson rather than Hodge who interpreted for him at the Washington hearing. Grayson had forty years' experience dealing with Washington, but Washington also had forty years' experience dealing with Grayson. In his final report to President Wilson on the Allen affair, Secretary Lane indicated that it was "Captain Grayson, a member of the Creek Nation, and a very fine man," who served as mediator between Tiger and the department. 79

Further evidence of official familiarity of the Bureau of Indian Affairs and Grayson lay in the commissioner's defense of him in the face of criticism from Superintendent Gabe Parker in 1916 that the interpreter's expense accounts exceeded those not only of other tribal officers but also of Chief Tiger. ${ }^{80}$ Sells replied, "Mr. Grayson is a man of quiet habits and...he is not given to incurring unusual or heavy expenses under ordinary circumstances." 81 Grayson was just the type of competent, acculturated Indian Sells hoped to see emerging from the wardship of the Federal Government. It was not at all surprising that 
he was willing to allow the Creek interpreter extra latitude. 82

Other items listed as Grayson's expenses also demonstrated that Grayson was more than just the chief's interpreter; he was also an unofficial delegate. He received the standard per diem of four dollars out of state and three in state, as well as telephone service, postage, and trolley tickets. Sells disallowed two months' subscription to the Congressional Record that Grayson read rather than attend each day's session. 83 In April 1915 Sells granted permission for Grayson to move his official headquarters to Eufaula from Muskogee in response to Allen's explanation that "a great many full blood Indians live in the vicinity of Eufaula, where Captain Grayson now lives and has lived all his life, and that it is necessary to use him at that point the greater part of the time."84 People throughout the creek country recognized that Grayson was the "real chief" even though Moty Tiger held the title. 85

Grayson also came to see himself as the real representative of the Creeks in such affairs as remained. He and Tiger spent several weeks in Washington in the early spring of 1916. Grayson told his son in early March that the chief would leave for home soon to look after his private affairs. "So," Grayson concluded, "I presume I will soon be the only one here to watch our business, still his going away will not change any of the conditions here, as I have already been in effect the only one to watch our interests even though the old gentleman has been with me all the time." 86 Grayson's salary of $\$ 1,200$ per year and expenses was probably a bargain for the hard-pressed Creeks even if Superintendent Parker begrudged it as extravagant. 
Grayson's duties allowed him to live in Eufaula and to commute by train on a regular basis to Muskogee for conferences with Chief Tiger and Allen. Consequently, he could oversee his lawn, flowers, trees, garden, and chickens as well as attend his remaining farmland. He could also indulge in his avocation, reading and writing history. Grayson, the mediocre scholar at Asbury, developed through the years into a selfeducated man with a devotion to learning. On the east side of his home on Jefferson Avenue and detached from it was the one-room building that housed Grayson's library. Shelves of books covered each wall from floor to ceiling. Most of his books were histories, and Grayson often lamented that he could not afford to buy as many rare old volumes, as he wished. 87

Here Grayson found privacy to read and write. He planned for some time to write a history of the Muskogee people as he understood them, to preserve their culture and past; but he completed another project first. At the urging on his children he wrote an autobiography between 1905 and 1912. It dealt primarily with his Civil war experiences and sketched in the rest of his eventful life. By now writing was a habit and a pleasure, whether it was a linguistic explication or the day's entry in his journal. As early as 1889 Grayson formed the habit of carrying a pocket diary in which he noted the details and impressions of his life. Over twenty years he filled at least forty-four of these little volumes, providing a very rare insight into the events affecting the Creek people from 1898 to 1917.88

Grayson was a generous scholar and enjoyed sharing information and discussing his views with others. He conferred with linguist and 
missionary Anne Eliza Worcester Robertson on Muskogee orthography, discussed literature with Alexander Posey, and swapped Civil War reminiscences with Creek Union veteran James Roane Gregory. By the early 1880 s he was interested in the work of anthropologists at the Smithsonian Institution. As a delegate, he provided information for Albert s. Gatschet's study of Creek migration. ${ }^{89}$ On his visit to Anadarko Agency in 1889, he took notes on his Kiowa and Wichita hosts for Major John Wesley Powell. At the turn of the century, he contributed an article on Opothleyahola to Frederick Webb Hodge's Handbook of American Indians. John R. Swanton came to the Eufaula area several times beginning in 1911 to study the Creek people. The Graysons opened their home to him, introduced him to other knowledgeable Creeks, and so facilitated his work that he considered his Social Organization and Social Usages of the Indians of the Creek Confederacy a memorial to Grayson. 90

The Grayson house was, in fact, rarely empty of visitors. Besides Swanton, family tradition holds that Patrick Hurley, a Choctaw and future ambassador to China, stayed with them. So did a number of aging relatives and solitary young people such as Rosa Marshall whitlow and Thomas Gilcrease, a Creek orphan and later an oil tycoon. The Graysons maintained a proprietary and sentimental interest in Eufaula Boarding School; and on Sunday afternoons the female students regularly took over the Grayson parlor, piano, and kitchen. Rarely did Wash and Annie Grayson sit down to a meal alone. Annie usually served meals in shifts, to the men first, the women next, and the children last in a dining room that seated about fifteen. Friends, relatives, children, and grandchildren knew they were always welcome at the Wash Grayson house on 
Jefferson Avenue. 91

All four of the Grayson children who survived into adulthood lived nearby in Eufaula. Lena died at age twenty-two, leaving two small children. Walter Clarence became a Eufaula businessman. Washington, the Graysons' second son, pleased his father by graduating from a military academy and serving five years as an officer in the Philippine Constabulary before returning to Eufaula. The Graysons provided Eloise and Tsianina with good educations and presented each with a house next door. Consequently, their children considered their grandparents' home an extension of their own. They saw Grandfather Grayson as stern old gentleman with a soft spot for children, especially Grayson (Gracie) and Mildred Fuller (Millie Mitiwohli). One of Mildred's first memories was of holding onto Grandfather Grayson's leg while he and Mr. Swanton strolled around the garden and discussed Creek history. 92

All of the Graysons took active roles in Eufaula's social life. Social occasions were typical of most small towns of the day: literary discussions, musical evenings, picnics, and garden parties, in addition to a traditional Creek event, the fishkilling. Annie Grayson, in her husband's absence, made a full life for herself with church work, sewing circles, and the Masonic ladies' auxiliary. Oddly enough, the only organization in Eufaula Grayson did not join was the Masonic Lodge. He was for many years Sunday school superintendent at one of the numerous Creek Baptist churches near Eufaula. 93

Near the turn of the century, Eufaula began to lose its character as an "Indian town" and its pattern as a railroad town. White merchant C. E. Foley built a mansion on Chintz Mountain, site of the historic 
Creek council of 1861, and townspeople renamed it Foley's Mountain. Automobiles made their appearance about 1902, and the business district shifted a block west to flank present-day Highway 69. The McIntosh County Court House moved the center of gravity still another block west. Grayson Brothers' old store site on the east side of the tracks became a commercial backwater while imposing new business buildings testified to the importance of newcomers to the town. These were white families from Missouri, Arkansas, and Alabama; and they brought a distinctly southern flavor to Eufaula. Among other things, they organized a camp of the United Confederate Veterans and its various auxiliaries. Grayson joined and eventually rose to brigadier general of the Creek Brigade of the Indian Territory Division. Grayson joined other Confederate Veterans as in 1917 they finally marched triumphantly into Washington to their reunion. 94

Although the new character of Eufaula was increasingly southern and white, the Graysons, for all their association with these newcomers, did not give up their Creek identity. She encouraged his ambition to write a history of the creeks and helped him edit his work. So great was her contribution that Grayson dedicated it to her. Annie shared his sense of injustice as well as pride in being Creek. Like him, she refused to be anything else. About 1918 some of her Stidham relatives who had moved to California invited her to come out for a visit. Annie packed her bags and was ready to leave when a note arrived. Her hosts advised her that because being Indian was not acceptable in California, she should not mention her heritage while visiting there. Annie, according to her granddaughter, tore up the letter, unpacked her bags, and refused 
to have any further contact with those unnatural stidhams. 95

Grayson maintained his ties to his fellow Creeks publicly and privately. His official duties, of course, kept him in contact with those full-bloods who could not speak English or understand the white ways. But he also attended Creek ball games and the green corn festival, activities many Christian Creeks now regarded as backsliding. Federal officials, too, disliked the tribalism associated with such events; but Grayson defended them to Commissioner sells. While his attendance at traditional ceremonies were probably as much historical research as real participation in these ancient celebrations, he cared enough to see that his son Washington received his war name just as he had in his youth. 96

By 1917 there seemed to be little left of the Creek government; yet enough business remained that when Moty Tiger left the chieftaincy Grayson replaced him. The circumstances under which the transition took place are unknown, but it is probable that Tiger was forced to resign and that the intrigues of 1914 continued. In a telegram dated october 5 Moty Tiger denied that he had either resigned or recommended G. W. Grayson as his successor, and he urged the department to delay any action. Yet Grayson received a presidential appointment on November 13 and signed the oath of office November 27.97

At age seventy-five Grayson must have found this latest development somewhat ironic: The Principal Chief of the Creek Nation was now just another Federal employee. He carefully filled out a personnel form on which he noted, "Do not recall any time since I have been of man's estate when some tribal responsibility did not rest upon me." As 
evidence of his ability to fill the position he wrote, "Having been born and reared among the Creeks of the full blood class, and been in intimate relations with them all these years, I believe I have an allaround knowledge of them that enables me to understand and manage them better than some others." While he claimed to be an expert linguist in Muskogee, he denied any skill as a clerk or typist. Quizzed about his musical ability, he answered tongue in cheek, "Can perform creditably well on the Jewsharp, but have not cultivated the art assiduously."98 Most of the major issues that so concerned Grayson early in the century were long-since resolved. There were still many suits against grafters to be prosecuted, but this was the province of James C. Davis, the new Creek attorney. Of the 18,761 enrolled Creeks, 8,556 remained restricted, their homesteads unsalable and untaxable until 1931. Many also had equalization funds held in trust by the Federal Government. Most agreed with Grayson that this state of affairs should continue for their protection; however, Grayson dutifully forwarded the petitions of those who wanted their restrictions lifted. When the Competency Commission visited the Creek country in the summer of 1918, he explained its mission to the full-bloods to quiet their fears as he had explained the negotiations with the Dawes Commission to them two decades earlier. ${ }^{99}$ Grayson also presided over the disposition of the Creek Council House in Okmulgee. For several years it served as the Okmulgee county Court House; then Grayson leased it to the Red Cross during World War I. Because of the town's growth and oil development, the market value increased to $\$ 100,000$. While it must have been painful for Grayson to oversee its sale, he was intent during his chieftaincy on seeing the 
Creeks realize the full value of their assets. He probably hoped the sale price would be passed on to those Creeks he felt had been shortchanged in the equalization of their allotments. 100

More important to Grayson than either of these matters was the Creek boundary issue. According to the Reconstruction Treaty of 1866 , the Creeks ceded to the Federal Government the western half of their territory, some of which the Seminoles bought. In 1871 Frederick w. Bardwell surveyed the north-south line marking the Creeks' western boundary. One year later E. M. Darling, surveying the Sac and Fox Reservation, placed his markers too far east of the Bardwell line into the Creek Nation. Another survey perpetuated this error, and it stood until the United States Geological Survey of 1895-1896 reestablished the Bardwell line as correct. Creeks were aware of the error as it affected the Seminoles and brought it to the attention of the Department of the Interior. But in 1906 Commissioner W. A. Richards of the General Land Office said that the error in fact existed the length of the Creek west boundary from Township $11 \mathrm{~N}$ to $19 \mathrm{~N}$, Range 6 East, embracing in all $5,575.57$ acres in present-day Lincoln and Pottawatomie counties. 101 Grayson and other Creek officials periodically sought redress from the Seminoles or from the Federal Government. But the matter had never been resolved even though Grayson conferred with the Seminoles as late as 1899 with the knowledge of Commissioner of Indian Affairs E. A. Hitchcock. That official so supported the Creeks' case that he drafted a bill recognizing the error and asking $\$ 30,000$ to recompense them. But Commissioner Wright at Union Agency said his office had no knowledge of any such claim, and Congress failed to act. Grayson unsuccessfully 
revived the issue in 1908 while trying to replenish Creek funds before allotment. By then the error created an intimidating legal tangle: Some of this Creek land had already been homesteaded in the earlier land runs while other parts had been allotted to seminoles. The state had been taxing portions of it in error for years. Some of it overlay the rich Seminole oil Field, increasing its value far beyond the original assessment. 102

Now that he was chief, Grayson took the matter to Commissioner Sells in December, 1918. Sells obliged Grayson by asking his office to investigate, but the information was so slow in coming that Grayson instructed Creek attorney Davis to pursue it. The dilatory response of the departmental bureaucracy and Davis's own press of business prevented action for more than a year. Grayson, perhaps realizing the time left to him was limited, grew impatient. ${ }^{103}$ In January 1919 Davis tactfully urged Sells to immediate action:

I think the Captain feels that this is an instance in which he can be of real service to the people of the Creek Nation, and he desires to take advantage of the opportunity thus afforded him... he has the matter very much at heart... because of a zealous desire upon his part to perform some active duty that will result beneficially to the members of his tribe. 104 Nothing more happened before May 15. Grayson habitually traveled by train to Muskogee the first and fifteenth of each month to attend business at the Creek executive office. This time he arrived a day early and found the entire staff away at a competency hearing. He spent the night in town but felt ill and decided to return home the following morning. While waiting for his train at the Katy Depot he suffered a stroke. He insisted on going home to Eufaula, and by the time he arrived paralysis affected his right side. The stroke was so severe few 
expected him to recover; but four days later when Davis visited him, he found Grayson alert, cheerful, and optimistic, his enunciation only slightly impaired. 105

During the weeks of his recovery, the Creek boundary issue receded again into bureaucratic obscurity. However, Grayson showed the same determination to have it concluded that he demonstrated in his rehabilitation. He never completely recovered the use of his right arm and leg. For the remaining eighteen months of his life he walked with a cane as he tended his garden and went about his affairs. He refused to give up writing and taught himself to type when using a pen proved too frustrating. By July he was able to resume his visits to the Muskogee office, and his most pressing concern was the boundary claim. It was, Davis wrote repeatedly to the Commissioner, the topic nearest his heart. Unfortunately, Sells's office insisted in February 1920 that the staff found no records of any such claim. As of Grayson's death the following December the problem was still unresolved. 106

By then a new issue, that of Grayson's successor, supplanted it. In the summer of 1920 some Creeks foresaw in Grayson's recent illness the possibility of a vacancy in the office of principal chief. Knowing just what happened is difficult because of conflicting accounts. Grayson probably called together some Creeks to ask their advice regarding a successor in the contingency of his resignation or death. While the office involved little now except signing payroll warrants, the chief, especially if he were as knowledgeable and respected as Grayson, influenced the choice of national attorney. And, as the Allen controversy demonstrated, the diligence and dedication of the attorney in 
prosecuting suits of the nation or of individual Creeks were important to a number of prominent Oklahoma businessmen. At that moment Davis was continuing a suit begun by Allen to recover the duplicate allotment of Hettie Lena, a valuable oil property for which the nation had been offered $\$ 75,000$ to settle out of court. 107

Late in June 1920 Grayson decided to resign. He told his brother Sam that his inability to get around and visit his people frustrated him; there was so little to do he felt he was being paid for nothing. Consequently, Grayson tendered his resignation to President Wilson and suggested Jefferson Canard or Louis Dunzy as his successor. They were, he believed, honest men, fluent in English and Muskogee, and satisfactory to their fellow Creeks. 108

Grayson's action energized those with vested interests in the chieftaincy. Applications for the position arrived in Washington within days. Partisans backed a number of candidates and tarred the opposition with charges of grafting. Superintendent Parker eliminated Dunzy. Eastern Oklahoma Democrats led by Senator Owen backed William Porter, son of Pleasant Porter. Republicans supported George W. Hill and, once Harding won the election of that November, tried to prevent any further action until after he took office. Most of the controversy surrounded Grayson's candidate, Jefferson Canard. Former attorney Allen objected to him because his brother Felix was a well-known grafter, while Davis upheld Jefferson Canard and questioned the meddling of former attorneys Mott and Allen in the matter. Once again the Creek people with no official forum and little access to the Federal bureaucracy that managed their affairs resorted to mass meetings and petitions. 109 
The agitation over Grayson's successor apparently startled the Department of the Interior. Sam Grayson spoke for many Creeks when he asked the Department to delay any decision. Sam's interest was purely personal. He knew that his brother's main interest was in bringing the affairs of the Creek people, such as the boundary claim, to a successful conclusion. Speaking for the Grayson family, Sam asked that his brother retain his office until that was accomplished. For whatever reason, the Department refused to accept Grayson's resignation; and the issue of his successor continued to disturb the Creeks. 110

The controversy over his successor must have seemed to Grayson symptomatic of the conditions under which the Creeks existed after 1906. As well as the right of self-government and control of their property, these children of the ancient Creek confederacy lost any official vehicle through which to express themselves. Their Council met no more; their chief was a Federal appointee and a convenience of the Federal bureaucracy. Among the complex and far-reaching affairs of the Federal Government, their views and problems--fear of the alien concept of allotment, restrictions, equalization, recompense for lost territory, and the disposition of their assets--were of negligible consequence. Moreover, this affair demonstrated a development Grayson recognized with regret. In addition to the pride he took in the Creek system of government and affinity for statecraft, he had always esteemed the Creek people for their ancient traditions, beliefs, and values. He admired their bravery, patriotism, generosity, hospitality, integrity, and tolerance, qualities Euro-Americans held up as the Christian ideal, yet failed to exhibit. It was to correct the popular American image of 
the Indian as a savage that he cooperated with the anthropologists; it was to give the Indian his due in American history that he began his own narrative.

Yet this affair illustrated that the mixing of Creek blood with that of the African and the European, the "contamination resulting from association with other races and peoples"111 as he called it, had been detrimental to the creeks. Some, particularly the mixed-bloods, had become so like the whites in their acquisitiveness as to victimize their fellow Creeks through grafting. The result was more factionalism and acrimony as partisan groups struggled to control the vestigial creek executive office. For the full-bloods, those who Grayson believed best personified the old admirable qualities, this could only mean widening the gulf between them and the man appointed to be their chief. 112

With this bitter state of affairs unchanged, Grayson died on the afternoon of December 2, 1920. As the news spread throughout the Creek country, full-blood, mixed-blood, and white friends came to Eufaula. That many full-bloods came on foot and by pony from miles away testified to their respect for Chief Grayson. By Saturday morning hundreds were encamped near the house on Jefferson Avenue. Annie Grayson set aside her private grief and, according to Creek custom, prepared food for them. Then the Creeks buried their chief at Greenwood Cemetery in Eufaula, on a quiet hillside overlooking the North Canadian River. ${ }^{113}$

Even as the funeral took place, mourners speculated as to who would replace Grayson as chief. It was perhaps indicative of the atmosphere that one of the tributes paid to Grayson hinted at this same issue. R. C. Allen wrote to Commissioner sells, "I have never known a man, white 
or red, in whom I had greater confidence than Capt. Grayson. If ever a man lived a godly life, he did. During his life time he held many offices in the Creek nation and for fifty years has been regarded as one of the most conscientious, devoted and learned members of the Tribe." Then Allen pressed his point: the nomination of Washington Grayson "will certainly be a credit to the Tribe, as well as a deserving recognition of the long and faithful service of his father."114 After several weeks of contention and controversy, of charge and countercharge by the candidates and their backers, the Department of the Interior made its own selection for its own reasons. Washington Grayson became Principal Chief of the Creek Nation. He had served honorably in the Philippine Constabulary for five years, had risen to the rank of captain, and had gained experience in the civil and military administration of several large Philippine provinces. On his return to Eufaula he served as secretary to Chief Moty Tiger until 1917. He volunteered for duty during World war $I$, served with distinction in France, and on his promotion to major became one of the two highest ranking Indian officers overseas. In spite of the fact that Major Grayson did not speak Creek and had spent most of his adult life away from the Creek country, the administration presumably believed these experiences qualified him for the position. 115

That he was not a part of the current factionalism perhaps worked in his favor as far as the Federal Government was concerned. The office of Indian Affairs made its decision with reference only to superintendent Parker in Muskogee. What the Creeks wanted seemed not to be a prime consideration. However well Washington Grayson performed in the 
office, he illustrated the distance of officialdom from the Creek people and their powerlessness to change it.

George Washington Grayson understood that powerlessness and did all he could for Creek interests and Creek rights in spite of it. He fought to maintain the integrity of the Indian Territory until the barriers fell in 1889. He fought to sustain Creek self-government until the formal dissolution of the nation and then carried on within the vestigial executive office. He fought for the Creek landholding system until allotment replaced it, and then he fought to help individual Creeks keep their lands under the new system. He fought for the maximum equalization of allotments, and when Creek funds proved insufficient he fought to retrieve lands lost in the boundary survey to help make up the difference. What a bitter thing it must have been for him to see so many battles lost and so many treaties, agreements, and promises broken. Writing his history during World War I and near the end of his life, Grayson pointed to the hypocrisy he saw in the white Americans' treatment of Indians: While they condemned Germany for trampling on the rights of weaker nations, white Americans behaved just as savagely toward "the poor and the weak" Indian. He concluded, "without some general awakening of the public conscience of the people of the United States in the interest of common justice toward the red man, there appears to be little prospect of his ever coming into his own." Then, perhaps, he summarized his own political life: "Like true patriots and true men, we battled long and well in the unequal contest finally losing out."116 For George Washington Grayson the solitary rear guard, the long campaign was over. 
NOTES

1J. Leitch Wright, Jr., Creeks and Seminoles: The Destruction and Regeneration of the Muscogulge People (Lincoln: University of Nebraska Press, 1986), 33.

\begin{abstract}
2Hamlin Garland, "The Final Council of the Creek Nation," in Hamlin Garland's Observations on the American Indian, 1895-1905, ed. Lonnie E.
\end{abstract} Underhill and Daniel F. Littlefield, Jr. (Tuscon: University of Arizona Press, 1976), 190.

${ }^{3}$ The offices of the Union Agent, Indian inspector for the territory, the supervisor and superintendent of schools, revenue inspector for the Creeks and Cherokees, and supervising engineer of the town-site survey were located in the Masonic Building in Muskogee, owned by C. W. Turner and his associates. Turner, of course, was the same white man who made his fortune in the Creek Nation as a merchant, rancher, and close associate of Chief Pleasant Porter. Report for the Agent for Union Agency, Indian Affairs, Part 1, Report of the Commissioner, Annual Reports of the Department of the Interior for the Fiscal Year Ended June 30,1901 (Washington, D.C.: Government Printing Office, 1902), 220 (hereafter cited as AR DI).

${ }^{4}$ The original delegation included Grayson, Porter, and Roley McIntosh. Inspector J. George Wright to the secretary of the Interior, April 13, 1906, 1906-34274, Office of Indian Affairs, Letters Received, 
Department of the Interior, Record Group 75, National Archives, Washington, D.C. (hereafter cited as OIA LR).

${ }^{31}$ Stat., 861; Angie Debo, And Still the Waters Run: The Betrayal of the Five Civilized Tribes (Norman: University of Oklahoma Press, 1940, paperback edition, 1989), 86-91.

6Application Number 2291, Western District of Indian Territory, July 14, 1905, 1905-63909, OIA LR.

${ }^{7}$ Debo, And Still the Waters Run, 179.

${ }^{8}$ William T. Martin, Jr., an employee of the Dawes Commission, was convicted of the theft of the Creek census roll. Tulsa Daily World, January 26, 1907. New-State Tribune (Muskogee, Indian Territory), April 5, 1906; Creek National Attorney M. L. Mott, Presentation to the Commissioner of Indian Affairs, received June 30, 1910, 33359-1909-Creek313, Part 1, Equalization of Allotments, Central Classified Files, Record Group 75, Bureau of Indian Affairs, NA (hereafter cited as CCF).

${ }^{9}$ Indian Affairs, Part II, AR DI 1903, 175-176; Tulsa Daily World, November 23, 24, 1906.

${ }^{10}$ Tulsa Daily World, November $24,1906$.

${ }^{11}$ Ibid.

${ }^{12}$ Grayson did not testify before the committee but subsequent statements demonstrate his opinion. Ibid. 
${ }^{13}$ Betty Tiger Miller, "Moty Tiger," History of Okmulgee County, Oklahoma, compiled and edited by the Okmulgee Historical Society and the Heritage Society of America (Tulsa: Heritage Enterprises, 1985), 13071309.

${ }^{14}$ Ibid., 1308.

${ }^{15}$ Unaddressed and unsigned letter, December 3, 1907, I-2, Grayson Family Collection, Western History Collection, University of Oklahoma, Norman, Oklahoma; Debo, And Still the Waters Run, 178.

\footnotetext{
${ }^{16}$ Members of the Chitto Harjo delegation that winter were silas Jefferson, Pompey Phillips, Robertson Starr, David Derrisaw, and a Seminole named Kun-char-to-chee. Unaddressed and unsigned letter, December 3, 1907, I-1, Grayson Family Collection.
}

17 "Removal of Restrictions on Indian Lands in Oklahoma, " H. R. 15641, Hearings Before the Committee on Indian Affairs, House of Representatives, 60th Congress, 1st Session (Washington, D.C.: Government Printing Office, $1908), 59$.

18 Ibid., 60.

${ }^{19}$ Tiger had Grayson read a letter from Chief John s. Brown of the Seminoles that seconded their position. Ibid., 60-61, 111.

${ }^{20}$ Ibid., 165.

${ }^{21}$ Ibid., 164-165. 
${ }^{22}$ Ibid. , 165-166.

${ }^{23} 35$ stat., 312; Debo, And Still the Waters Run, 179-180.

24Debo, And Still the Waters Run, 197.

${ }^{25}$ The Five Tribes Act, 34 stat., 822, allowed the continuation of the tribal governments indefinitely. Creek mixed-blood Alexander Posey bought the Indian Journal in 1907, but he drowned shortly thereafter in the floodwaters of the North Canadian River. The newspaper is still published in Eufaula, Oklahoma, one of the oldest continuously published journals in the state. Mary Hays Marable and Elaine Boylan, A Handbook of Oklahoma Writers (Norman: University of Oklahoma Press, 1939), 7780; Grayson and Johnson E. Tiger to Secretary James R. Garfield, January 13, 1908, I-2, Grayson Family Collection; Debo, And Still the Waters Run, $64-65$.

${ }^{26}$ Grayson and Roley McIntosh to the Commissioner of Indian Affairs, December 28, 1905, 1905-104065, OIA LR. Debo noted that the Creeks were the only tribe ever to receive even a partial accounting. Debo, And Still the Waters Run, $65,75,84-85$.

${ }^{27}$ Grayson to the Commissioner of Indian Affairs, undated, 190617053, OIA LR.

${ }^{28}$ Ibid.

${ }^{29}$ Debo, And still the Waters Run, 74-75, 84-85. 
$3_{31}$ stat., 861; Resolution of the Creek Council, November 3, 1904, Wright to the Secretary of the Interior, August 23, 1907, November 25, 1908, 33359-1909-Creek-313, Part 1, CCF.

${ }^{31}$ Porter, Grayson, and Hodge to the Commissioner of Indian Affairs, February 1, 1907, 33359-1909-Creek, 313, Part 1, CCF.

${ }^{32}$ Commissioner of Indian Affairs to the Secretary of the Interior, September 7, 1907, 5-1, Acts and Resolutions, Five Civilized Tribes, Indian office, office of the secretary, Department of the Interior, NA (hereafter cited as FCT).

${ }^{33}$ Chief Tiger and the Creek delegates to Secretary Garfield, January 13, 1908, F-1, Creek, Tribal Officials, Part 1, FCT.

${ }^{34}$ Grayson to Secretary Garfield, May 20, 1908, I-17, Grayson Family Collection.

${ }^{35}$ Grayson to Garfield, May 25, 1908, Resolution of the Creek National Council, November 5, 1908, 33359-1909-Creek-313, Part 1, CCF; Wright to the Secretary of the Interior, December 1, 1911, F-1, Creek, Tribal Officials, Part 1, FCT; Debo, And Still the Waters Run, 203-205.

36 Memorandum, Department of the Interior, January, 1909, Acting Commissioner of Indian Affairs R. G. Valentine to the Secretary of the Interior, March 24, 1909, 33359-1909-Creek-313, Part 1, CCF; Muskogee Phoenix, April 18, 19, 23, 1909; Chief Tiger to Wright, November 24, 1908, 
35697, microfilm, Reel 23, Creek National Records, Oklahoma Historical Society Archives, Oklahoma City, Oklahoma (hereafter cited as CRN).

${ }^{37}$ Chief Tiger to the secretary of the Interior, February 1, 1910, 33359-1909-Creek-313, Part 2, CCF.

${ }^{38}$ M. L. Mott's Presentation to the Committee on Indian Affairs, April 30, 1909, Mott to Assistant Secretary Samuel Adams, July 21, 1911, 333591909-Creek-313, Part 2, CCF.

${ }^{39}$ See various Senate and House bills, 33359-1909-Creek-313, Part 1, CCF; Wright to the secretary of the Interior, December 1, 1911, Petition from H. M. Harjo to the Secretary of the Interior, July 30, 1912, 5-1, Creek, Tribal officials, Part 1, FCT.

${ }^{40}$ It is highly likely that Grayson wrote this letter describing his services. Tiger to Wright, November 24, 1908, 35697, CRN 23.

41 Ibid.; F.H.A. to the Secretary of the Interior, November 11, 1912 , 5-1, Creek, Tribal officials, Part 1, FCT.

42 Petition to the Secretary of the Interior, May 1, 1913, F-1, Creek, Tribal Officials, FCT; Debo, And Still the Waters Run, 250-252.

43Allen to Commissioner of the Interior Cato Sells, February 20, 1914, blank ballot form, February 19, 1914, First Assistant Secretary A. A. Jones to Chairman John H. Stephens, House Committee on Indian Affairs, April 4, 1914, 33359-1909-Creek-313, Part 2, CCF. 
4438 Stat., 599; Page identified only "Muskogee, Oklahoma, August, 1914," Allen to Sells, August 6, 1914.

45 Wright to the Commissioner of Indian Affairs, August 19, 1914, official notice from wright to Field Clerk J. F. Farrar, August 29, 1914, Wright to Sells, August 29, 1914, ibid.

46 Muskogee (Oklahoma) Phoenix, July 11, 1915.

${ }^{47}$ Exhibits in Re Allen Investigation, 83406-1915-Creek-154, Probate 1, Part 1, CCF.

${ }^{48}$ The best study of grafting is, of course, Angie Debo's And Still the Waters Run. "Richard Clyde Allen," Chronicles of Oklahoma 36:489491; Chief Inspector E. B. Linnen to Sells, June 7, 1915, 83406-1915Creek-154, Part 1, CCF, 1-8, 15-16.

${ }^{49}$ Debo, And Still the Waters Run, 252-253, 259.

${ }^{50}$ The date of the renewal was July, 1914. Affidavit of G. W. Grayson, Exhibits in Re Allen Investigation, June 7, 1915, 83406-1915Creek-154, Part 1, CCF.

${ }^{51}$ Ibid.; Secretary Lane to President Wilson, June 28, 1915, ibid.

52 Various telegrams, April 28, 29, 1915, Billie Bruner to Sells, May 7, 1915, Sells to Bruner, May 10, 1915, 83406-1915-Creek-154, Part 2, CCF.

${ }^{53}$ Statement of Sarty Cowe to Special Indian Agent Fred S. Cook, 
83406-1915-Creek-154, Part I, CCF; various letters, May 21, 1915, 834061915-Creek-154, Part 2, CCF.

54Linnen to Sells, June 7, 1915, 83406-1915-Creek-154, Probate I, Part I, CCF, 38-39.

55 Ibid.

${ }^{56}$ Ibid., 47-52; George C. Morgenstern to Sells, May 27, 1915, ibid.

${ }^{57}$ R. C. Armstrong to sells, June 8, 1915, 83406-1915-Creek-154, Part 3, CCF.

58 Ibid.

59 Bruner to Sells, May 10, 1915, ibid.

${ }^{60}$ Iinnen to Sells, May 31, 1915, 83406-1915-Creek-154, Part 3, CCF.

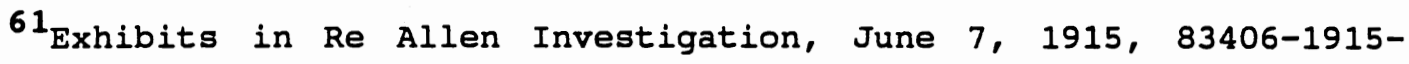
Creek-154, Part 1, CCF.

62 Ibid.

63 Affidavit of G. W. Grayson, June 7, 1915, ibid.

${ }^{64}$ Ibid.

${ }^{65}$ Ibid.

${ }^{66}$ Ibid. 
${ }^{67}$ Testimony of Frank L. Montgomery, testimony of R. C. Allen, ibid.

${ }^{68}$ Indian Journal (Eufaula, Oklahoma), July 16, 23, 1915; Muskogee Phoenix, July 11, 1915.

${ }^{69}$ Sarty Cowe to Sells, June 28, 1915, 83406-1915-Creek-154, Part 2, CCF .

${ }^{70}$ Sells to Grayson, June 25, 1915, Sells to Tiger, June 25, 1915, C. W. Lumpkin to Allen, June 23, 1915, Maude Roberts to Sells, June 27, 1915, Lane to Tiger, June 29, 1915, 83406-1915-Creek-154, Part 3, CCF.

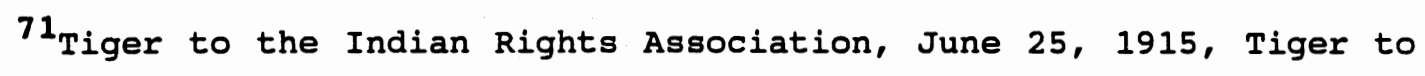
Owen, June 25, Roberts to Sells, June 25, 1915, ibid.

72 Brosius to Lane, July 9, 1915, ibid.

${ }^{73}$ Ibid.

${ }^{74}$ Lane to Wilson, June 28, 1915, ibid.

${ }^{75}$ C. W. Lumpkin to Allen, July 12,1915 , ibid.

${ }^{76}$ Tiger to Lane, July 28, 1915, ibid.

${ }^{77}$ Abstract of the Annual Report of the Superintendent for the Five Civilized Tribes for the Fiscal Year Ended June 30, 1916, 5-1, Part 3, Annual Reports, General, FCT, 8.

${ }^{78}$ Congressman James Davenport to Wilson, July 3, 1916, Assistant 
Commissioner E. B. Merritt to Sells, July 14, 1916, 83406-1915-Creek-154, Part 3, CCF.

${ }^{79}$ Lane to Wilson, July 19, 1915, 2448, Woodrow Wilson Papers, microfilm, reel 335, Library of Congress, Washington, D.C.

${ }^{80}$ Superintendent to the Five Civilized Tribes Gabe E. Parker to Sells, April 6, 1916, 25181-1914-Creek-162, CCF.

${ }^{81}$ Sells to Parker, April 17, 1916, ibid.

${ }^{82}$ Lawrence C. Kelly, "Cato Sells, 1913-1921," in The Commissioners of Indian Affairs, 1824-1977, ed. Robert M. Kvasnicka and Herman J. Viola (Lincoln: University of Nebraska Press, 1979), 243-250.

${ }^{83}$ Sells to Parker, April 17, 1916, 25181-1914-Creek-162, CCF.

${ }^{84}$ Allen to Sells, April 30, 1915, ibid.

${ }^{85}$ okmulgee (Oklahoma) Daily News, December 3, 1920.

${ }^{86}$ Grayson to Washington Grayson, March 8, 1916, VIII-38, Grayson Family collection.

${ }^{87}$ Creek Attorney James C. Davis to Sells, October 2, 1920, 694421920-Creek-163, CCF; Mrs. Mildred Fuller Ewens, interview with the author, Eufaula, Oklahoma, October 12, 1989; G. W. Grayson, untitled manuscript (property of Mrs. Mildred Fuller Ewens, Eufaula, Oklahoma).

${ }^{88}$ Grayson, untitled manuscript; W. David Baird, ed., A Creek Warrior 
for the Confederacy: The Autobiography of Chief G. W. Grayson, Civilization of the American Indian Series (Norman: University of Oklahoma Press, 1988), 12-13; Grayson to Major John Wesley Powell, May 30, 1889, manuscript 568-a, National Anthropological Archives, Smithsonian Institution, Washington, D.C.; Harold O. Hoppe, "The Dissolution of a Nation: A Muscogee Retrospective," unpublished manuscript (property of Harold 0. Hoppe, Wichita, Kansas), ii.

${ }^{89}$ Grayson to Ann Eliza Worcester Robertson, June 9, 1899, 1899-992, Box 15, Historical Manuscripts, Special Collections, McFarlin Library, Tulsa University, Tulsa, Oklahoma; Marable and Boylan, $\underline{\text { H Handbook of }}$ Oklahoma Writers, 78-79; "G. W. Grayson," box 6, Grant Foreman Collection, Oklahoma Historical Society Archives, Oklahoma City, Oklahoma; Albert S. Gatschet, A Migration Legend of the Creek Indians, Brinton's Library of Aboriginal American Literature, No. IV (Philadelphia: D. G. Brinton, $1884), \mathrm{v}$

90 Grayson to Powell, May 30, 1889, manuscript 568-1, National Anthropological Archives; G.W.G., "Opothleyaholo," in Frederick Webb Hodge, ed., Handbook of American Indians North of Mexico, volume 2 (New York: Pageant Books, 1959), 141-142; John R. Swanton, "Social Organization and Social Usages of the Indian of the Creek Confederacy," FortySecond Annual Report of the United States Bureau of American Ethnology to the Secretary of the Smithsonian Institution, 1924-25 (Washington, D.C.: Government Printing Office, 1928), 31-32. 
91 Mrs. Mildred Fuller Ewens, Mr. Marshall Foley, Mrs. Dorothy Follansbee, interview with the author, Eufaula, Oklahoma, March 13, 1990.

92 The names "Tsianina" ("peeping") and "Mitiwohli" ("turning around") were two of Wash and Annie Grayson's contributions to Swanton's study of Creek naming customs. Swanton, "Social organization...of the Creek Confederacy," 100; Orlena Grayson sanger monument, Greenwood Cemetery, Eufaula, Oklahoma; Parker to Sells, December 13, 1920, 69442-1920-Creek163, CCF; Mrs. Mildred Fuller Ewens, interview with the author, Eufaula, Oklahoma, October 12, 1989, March 13, 1990.

${ }^{93}$ Interview of Sarah Adams, 1:222, "Indian-Pioneer Papers," Works Progress Administration, WHC; Indian Journal (Eufaula and Muskogee, Creek Nation), July 3, 1890, December 7, 1894, January 25, 1895, August 26, 1898; Mrs. Mildred Fuller Ewens, interview with the author, Eufaula, Oklahoma, October 12, 1989, March 13, 1990.

94Mrs. Dorothy Follansbee, interview with the author, Eufaula, Oklahoma, March 13, 1990, October 2, 1990; Sanborn Map, Eufaula, Indian Territory, January 1905, OHS Archives; application of G. W. Grayson to the United Daughters of the Confederacy, January 1, 1905, property of Mrs. Mildred Fuller Ewens, Eufaula, Oklahoma; Confederate Veteran 9 (August, 1901): 357; 25 (September, 1917):434.

${ }^{95}$ Grayson's untitled history of the Creeks is redolent with his sense of the injustice and hypocrisy practiced by Euro-Americans. Mrs. Mildred 
Fuller Ewens, interview with the author, Eufaula, Oklahoma, March 13, 1990.

96 Each of the Grayson children and grandchildren had a Creek name. Washington Grayson's name was Catsa Tustunnuggee; he probably received it in 1908 after his military service. "Creek Dances," box 6, Grant Foreman Collection, OHS Archives; Swanton, "Social Usages...of the Creek Confederacy," 102, 509-510, 574-577; Grayson to Sells, september 26, 1913, 116759-13-Union Agency-047, CCF; Mrs. Mildred Fuller Ewens, interview of the author, Eufaula, Oklahoma, March 13, 1990.

${ }^{97}$ Tiger died in August 1921 and was buried in the Tiger family cemetery after a three-hour service in Creek. Miller, "Moty Tiger," 1309. Tiger to the Commissioner of Indian Affairs, October 5, 1917, 94451, Status File, CCF; Presidential commission of George W. Grayson, November 13, 1917, Oath of Office, November 27, 1917, George w. Grayson file, United States Office of Personnel Management, St. Louis, Missouri.

${ }^{98}$ George W. Grayson file, Us Office of Personnel Management.

${ }^{99}$ This commission intended to identify and lift restrictions on competent Creeks so as to allow the Bureau of Indian Affairs to concentrate its attentions on the truly incompetent. Kelly, "Cato sells," 248-249; James McLaughlin and J. R. Wise to Lane, January 10, 1918, Grayson to Lane, November 21, 1918, Grayson to Sells, November 7, 1918, 77840-1918-Creek-127, Creek Competency Commission, Part 1, CCF. 
100 Sells to Lane, May 21, 1918, Acting Superintendent for the Five Civilized Tribes Joe H. Strain to Sells, July 21, 1919, Sells to senator Robert L. Owen, March 11, 1918, 16150-09-Creek-340, Creek Council House, CCF.

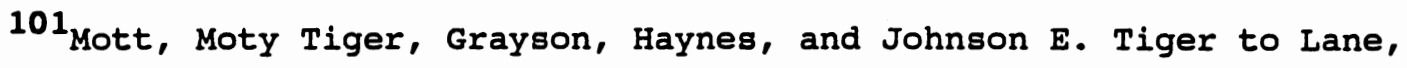
February 21, 1908, 28476-1911-Creek-304, Creek-Seminole Boundary, CCF.

102 Hitchcock to the President, January 11, 1900, 39726-A, CRN 36; Hitchcock to the Chairman of the Committee on Indian Affairs, House of Representatives, April 9, 1906, 28476-1911-Creek-304, CCF.

${ }^{103}$ Grayson to Sells, December 11, 1918, January 8, 1918, Davis to Sells, January 15, 1919, January 21, 1919, 28476-1911-Creek-304, CCF.

${ }^{104}$ Davis to Sells, January 21, 1919, ibid.

${ }^{105}$ Davis to Sells, May 15, 1919, May 19, 1915, George W. Grayson file, US Office of Personnel Management.

${ }^{106}$ Davis to Sells, July 25, 1919, Sells to Davis, February 20, 1920, 28476-1911-Creek-304, CCF; Indian Journal (Eufaula, Oklahoma), December 9,1920 .

${ }^{107}$ Davis to Sells, January 7, 1921, 69442-1920-Creek-163, CCF; Wright to the Secretary of the Interior, July 22, 1914, Allen to the Commissioner of Indian Affairs, October 30, 1914, Davis to Grayson, March 27, 1918, Grayson to Sells, March 12, 1919, 81252-1914-Creek-053, Hettie Lena-Emma Coker Case, Part 1, CCF. 
${ }^{108}$ Sam Grayson to Sells, July 7, 1920, 69442-1920-Creek-163, CCF; Grayson to President Wilson, June 28, 1920, George w. Grayson file, US Office of Personnel Management.

${ }^{109}$ Other contenders were Johnson E. Tiger, James H. Alexander, Samuel Logan, Peter R. Ewing, and William Sapulpa. Davis to Sells, July 21, 1920, Parker to Sells, July 21, 1920, Allen to Sells, January 7, 1921, Samuel B. Haynes and E. B. Childers to the Secretary of the Interior, August 17, 1920, petition of September 29, 1920, 69442-1920-Creek-163, CCF; Harlow's Weekly 20 (February 25, 1921):6-7.

${ }^{110}$ Sam Grayson to Sells, July 7, 1920, 69442-1920-Creek-163, CCF.

$111_{\text {Grayson, untitled manuscript. }}$

112 Ibid.

${ }^{113}$ Okmulgee (Oklahoma) Daily News, December 3, 5, 1920; Mrs. Mildred Fuller Ewens, interview with the author, Eufaula, Oklahoma, March 13, 1990.

${ }^{114}$ Allen to Sells, December 6, 1920, 69442-1920-Creek-163, CCF.

115 Daily Oklahoman (Oklahoma City), March 22, 1919; Parker to Sells, December 13, 1920, 69442-1920-Creek-163, CCF.

116 Grayson, untitled manuscript. 
CHAPTER VIII

"NEVERTHELESS, INTENSELY INDIAN"

The person who in 1908 wrote on the photograph of George Washington Grayson "shows no trace of Indian blood" did not know the man in the portrait. The observer based his judgment on appearances or common assumptions about mixed-bloods in the Five Civilized Tribes. Many observers, including historians, assume that the only "real Indian" is a full-blood and that the person who is part white wishes to be white. This is probably an ethnocentric assumption based on the belief that the white culture is the superior culture. That was never the case for Grayson. He knew who he was: He was a Creek and an Indian, and he had no desire to be anything else. For Grayson there was no internal crisis of identity and no external struggle for acceptance. 1

In part this was the result of his Creek heritage. The Creek culture was always inclusive. From the days of the creek confederacy, the Muskogees welcomed alien peoples and made a place for them in their political and social structure. That is quite evident in the number of Creek towns that did not speak Muskogee as their first language. Including these strangers, often remnants of other societies, on more or less even terms strengthened the whole confederacy and made it a dominant force in the southeastern region of the United states. When the Europeans arrived, the Muskogees showed them the same in- 
clusiveness. They accepted the English, Irish, French, and Scottish traders such as Robert Grierson into their towns. The maternalistic nature of Creek society made a place for their mixed-blood children. Because they understood both cultures, the Muskogee and English languages, the Creek political system and that of the whites, Creeks awarded these mixed-bloods places of importance in the political structure. As Creeks became commercial hunters within a market economy, the mixedbloods found status in the economic structure as well.

The dynamic nature of Creek society allowed the adaptation of aspects of white culture that creeks found good and useful--new forms of agriculture, education, religion, even government. Some Creeks regarded these changes with misgiving, but even the most conservative came to regard the adaptation of some white ways, particularly an English education, as a defense against the white men. Creek pluralism insured continuing acceptance of those who chose to follow the new ways as well as those who clung to more traditional ways.

Grayson was a member of the third mixed-blood generation of his family; and it was a family that was very much a part of the Creek national experience, in common with the McIntoshes, Kinnards, Stidhams, Perrymans, and Marshalls. White historians have generally assumed that mixed-blood Creeks followed the cultures of and identified with their white ancestors. That was not the case for Tulwa Tustunuggee, for James and Jennie Grayson, or for their son. They preferred to be Creek, and they enjoyed a place in creek society they probably would not have found in white society. How many other mixed-bloods, particularly the illiterate, simply blended into the larger Creek population and escaped the 
sight of historians?

Throughout Creek history there were forks in the road, points at which mixed-bloods such as the Graysons might perhaps have chosen a divergent route. The first was the Red Stick War of 1813-1814, a Creek civil war between mixed-blood dominated Lower Creeks and full-blooddominated Upper Creeks. The experience of Tulwa Tustunuggee drove him further toward full-blood conservatism and left him with a distrust and dislike of whites. The persecution of the Graysons at the hands of the Red Sticks drove them away from their full-blood neighbors and into the Lower Creek McIntosh faction. Yet, when the United States Government meted out punishment for the Red stick apostasy by taking much of the Creek domain, the retribution fell on the Creeks as a nation without regard for guilt or innocence. Mixed-blood and full-blood felt the same sense of injustice.

Conflict over removal and the voluntary migration of the McIntosh faction to the Indian Territory in the 1820 s separated the factions temporarily. But forced removal of the remainder of the nation in the 1830 s reunited them in shared domain in the Indian Territory. Moreover, the Upper Creeks yielded the leadership role to the mixed-bloods in the early years and continued to defer to them until the Civil War. The widespread acceptance of Christianity and education during the "Golden Years" reinforced the place of the acculturated mixed-blood in Creek society. Young Washington Grayson was fortunate to be of school age at the time the Creeks overcame the trauma of removal and welcomed the Christian missionaries and the education they brought.

Grayson approached adulthood just as the Civil War threatened the 
Creeks with division once more. Most historians have accepted that the division between Southern and Unionist Creeks lay along mixedblood/full-blood and conservative/progressive lines. Following a popular view of the Civil War, historians have ascribed to southern Creeks the motive of protection of slavery in their adherence to the Confederacy. But Creek tradition and survivor's accounts suggest their choice of loyalties was much more complex; the compelling motive for each faction was primarily the protection of the landbase. Whatever their loyalties, Creeks engaged in internecine warfare without equal except in the neighboring Indian nations. Here again, mixed-bloods and full-bloods might have gone their separate ways. But the punitive Reconstruction policy of the Federal Government, with its own ends in view, stripped Confederate and Union Creek as a nation of half their domain.

At the same time, perhaps because they preferred to deal with knowledgeable, English-speaking "progressives" or perhaps because they chose to deal from a position of strength, Federal officials recognized and reinforced the mixed-blood domination of Creek national affairs. Consequently, the post-war environment of the Creek Nation allowed Grayson to build a political career on the foundations of his education, kinship with Creek leaders, and Civil War associations. At the same time, the traditional communal landholding system offered an ambitious young man such as Grayson almost unlimited economic opportunity. Grayson said in 1917 that he never remembered a time after he reached a man's estate that he was not engaged in the affairs of his nation. Through his various political offices, especially his commis- 
sions as a diplomat, he came to understand the minority status of the Indian in a restless, aggressive United States. The developing of an Indian racial awareness in the post-Civil War Indian Territory is a theme yet to be explored by historians, but it is quite evident to anyone who reads the documents of the several nations. That awareness was based on a sense of common danger from a common source. Grayson understood that unless Indians stood together, they had little hope of protecting their right of self-government and their landbase. Grayson therefore participated willingly in the okmulgee Conventions, the international prosecution of David L. Payne, and the joint efforts of the national delegates against the opening of the territory to white settlement.

While unity was one defense against white aggression, a second was "progress." Publicly and privately Grayson repeated his belief that adaptation of some aspects of white culture were necessary if Indians were to be allowed to retain self-government and protect their landbase. He had absolute faith that Creeks could attain the same state of civilization as white Americans. He pointed to ancient Creek values he revered--generosity, hospitality, integrity, courage, and patriotism-as evidence that the Creeks had only a short distance to travel to reach the goal. Only by reaching it could they prove to white Americans that they were worthy of independence, equal consideration, and equal protection of their property. With this end in view Grayson applied himself to various economic enterprises. He joined other Creeks in wooing the Katy Railroad and helped found the new market town of Eufaula. He became a merchant and a 
rancher. He supported education and helped found the Indian Journal, not only for the dissemination of information to Indians but as an example to whites of what Indians could accomplish. of course he enjoyed the profits that allowed him to make a comfortable home for his family, and he built his enterprises on the communal landholding system. But he did not see himself as taking advantage of less energetic creeks. In fact, he urged them to follow his example as a means to exclude the intruder and protect their rights to the land they held as a nation. Whites viewed such activities as acculturation and progress toward eventual assimilation. Grayson saw them from a Creek perspective. He was a "progressive" because progress was necessary if Creeks were to preserve what they had. He was a progressive, but his goals were always conservative. Being a mixed-blood had less to do with the life-style he chose than being a creek.

Throughout the post-war period the Federal Government by supporting the constitutionalists in the Creek Nation against conservative opposition, sometimes from full-bloods and freedmen, strengthened mixedblood domination of Creek affairs. Mixed-bloods such as the McIntoshes, George w. Stidham, the Perrymans, Pleasant Porter, and Grayson led the fight to keep their borders closed to intruders. They worked diligently to protect the traditional communal landholding system from which they profited as farmers and ranchers. The alternative was an influx of aliens and imposition of allotment and alien rule, in Grayson's opinion, the ultimate evils. As the recognized leadership of their nation, these mixed-bloods were the political and economic establishment. There was no need for them to seek status or identity outside Creek society. They 
had everything to gain by protecting the Creek Nation as they knew it. Only towards the end of the century, as some of the mixed-blood leadership surrendered to the conviction that nothing they were ever going to accomplish would be enough to maintain Creek independence, did they concede their hold over Creek affairs. Voluntarily they began to step aside and to blend into the greater white society as they never had before. They finally took a divergent fork in the road about the same time full-blood conservatives lost faith in their ability to protect the whole nation.

Grayson invested much of his life in the Creek Nation, and he was one of the last mixed-bloods to step aside. The optimism with which he set out in the 1860 s and 1870 s to demonstrate the Creek capacity for civilization gradually faded. By the late 1880 s he was pessimistic regarding Federal protection of Indian rights. He was disappointed in the progressive Creek leadership that concluded the sale of the Unassigned Lands and undermined Indian Territory unity. And he was fearful of the creek future should allotment be forced on his people before they were ready to cope with it.

At the turn of the century, Grayson saw his worst fears realized with Creeks subjected to allotment, their border opened, their government dissolved, and themselves subjected to statehood in spite of treaties dating back to the 1830 s. In common with many other mixedbloods, he saved what he could from the approaching wreck; unlike them he did not go his own way afterward. As full-bloods assumed the leadership role vacated by the mixed-bloods, Grayson's particular talents and experience kept him near the center of such power as 
remained. Moty Tiger needed him, and there was still the chance he could accomplish something to preserve Creek interests. So Grayson to the end of his life retained his identification with the Creek government and the Creek people, even after the ties between the two became very tenuous and informal.

Grayson was a man very much aware of history, and he saw himself and his roles in life against the background of Creek and Anglo-European contact. A thorough knowledge of Creek history was necessary for a Creek representative to Washington; that history taught him that the main characteristics of the whites were their "all-absorbing cupidity" 2 and their hypocrisy. The white man bullied the weak and helpless Indian, coveted his land, broke treaty after treaty, and still castigated him as a savage. Grayson's personal experiences in dealing with whites left him bitter and imbued him with the same racism he detected in whites. Unlike them, he believed that the Indian race was superior. His heroes were Tecumseh, Osceola, Opothleyahola, Stand Watie, and Isparhechar--some of them mixed-bloods but Indian nationalists all. While there were some aspects of white culture he admired and imitated, some aspects of Creek culture he saw as expendable if the final result was preservation of creek independence, his actions and his writings demonstrate that he never wanted to give up being Creek to be part of a race he scorned.

Grayson's sense of identity, then, was founded on the inclusiveness of Creek culture that always made a place for the mixed-blood and on the dynamic character that easily incorporated useful aspects of white culture. Grayson's education and abilities as a businessman and diplomat 
made him valuable to the Creek Nation and for decades assured him a leading role in Creek affairs. His experiences with whites reinforced the mistrust of white Americans perhaps first transmitted to him by Tulwa Tustunuggee.

Grayson recognized that nature, in providing him pale skin and reddish hair, set him somewhat apart from his fellow Creeks even as his educational, business, and political advantages set him among the progressive mixed-blood elite. Quite early in life he learned to take on the coloration of his surroundings. As a child he played the games of his Creek schoolmates and spoke Muskogee. At Fayetteville he learned to dress and behave as his white schoolmates did. As an adult Grayson sometimes used his white appearance for his own purposes, as is evident in the Wichita-Caddo Reservation incident and his application for the lifting of restrictions on his allotment. One might speculate that Grayson cultivated the full white beard that set him apart in Okmulgee as camouflage adopted for the Washington environment. If a representative of the Creek Nation walked into a Federal office "looking like an Indian" he could expect to be treated as a ward of the government. If he walked in looking like a white businessman, he might well be treated as an equal and thereby accomplish more for the Creek people.

That Creeks understood Grayson and accepted him as one of them is quite evident in the responsibilities they entrusted to him and in the number of times they elected him to represent their interests. Only once, in Sarty Cowe's complaint in 1915, is there any record of their rejection of him; and that was the rejection of a minority faction of the Creek people in a time they felt generally abandoned and alienated. 
The only persons who doubted the degree of his commitment to the creeks seem to have been those misled by his "white" appearance and lifestyle. That he was born in the Creek Nation; lived there all his life; spoke Muskogee and proudly wore a Muskogee name; fought, worshipped, traded, and socialized with Creeks further validated his sense of personal identity. 3

One cannot, of course, attribute the experiences and perceptions of one man to all mixed-bloods or even to all creek mixed-bloods. But one can gain a better understanding of the complexity of the mixed-blood experience, particularly among the Five Civilized Tribes. Perhaps one day we will be able through access to his private journals to observe the changes in his world through his eyes. We will have a better understanding of his motives and his role in Creek affairs during one of the most critical times in Creek history. With such documentation as we have now, it is clear that Grayson's acculturation made him no less Creek in his own eyes or those of the Creek people. He spoke honestly when he said of himself, "While fortune and circumstance have placed me in some respects in advance of some of my fellow-countrymen, I am nevertheless intensely Indian." 4 
NOTES

$1_{\text {Angie Debo, who knew Creeks of the early twentieth century well and }}$ publicized their plight in numerous works, also distinguished between the "wealthy mixed bloods" and the "genuine Indians." Debo, The Road to Disappearance: A History of the Creek Indians, The Civilization of the American Indian Series (Norman: University of Oklahoma Press, 1941), 330.

${ }^{2}$ Grayson, untitled manuscript (property of Mrs. Mildred Fuller Ewens, Eufaula, Oklahoma).

${ }^{3}$ w. David Baird, "Are There 'Real' Indians in Oklahoma?" Chronicles of Oklahoma 68 (Spring 1990):5.

${ }^{4}$ Indian Journal (Eufaula and Muskogee, Creek Nation), July 7, 1881. 
BIBLIOGRAPHY

Primary sources

Federal Documents

Abert, J. W. Journal of Lieutenant J.W. Abert, from Bent's Fort to St. Louis in 1845. Senate Executive Document No. 438. 29th Congress. lst Session.

Commissioner to the Five Civilized Tribes. Annual Report. Part II. In Annual Reports of the Deparment of the Interior, 1901-1902. Washington, D. C.: Government Printing Office, 1901-1902.

Commissioner of Indian Affairs. Department of the Interior. Annual Reports, 1843-1901. Washington, D. C.: Government Printing Office, 1843-1901.

Department of the Interior. Annual Reports for the Fiscal Year Ended June 30,1901 . Washington, D. C.: Government Printing office, 1902 .

Department of the Interior. Indian office. Five Civilized Tribes Files. National Archives. Washington, D. C.

Goodwin, James E., ed. The Federal Reporter: Cases Argued and Determined in the Circuit and District Courts of the United States, August-November, 1881, vol. 8. St. Paul: Minnesota West Publishing Company, 1881.

Hitchcock, Ethan Allen. "Report on Frauds on Immigrant Indians." New American State Papers: Indian Affairs 10:528-530. Wilmington, Del.: Scholarly Resources Inc., 1972.

House of Representatives. Hearings before the Committee on Indian Affairs. H. R. 15641. 60th Congress. 1st Session. Washington, D. C.: Government Printing office, 1908.

House of Representatives. No. 5. 55th Congress. 3rd Session.

National Anthropological Archives. Smithsonian Institution. Washington, D. C. 
Photograph number 1116. Smithsonian Anthropological Archives. Museum of Natural History. Washington, D. C.

Record Group 48. Department of the Interior. Indian Territory Division. National Archives. Washington, D. C.

Record Group 75. Office of Indian Affairs. Department of the Interior. National Archives. Washington, D. C.

Central Classified Files.

Land Division.

Letters Received.

Letters Received, 1824-1881. Microfilm 234.

Records of the Central Superintendency, 1813-1878. Microfilm 856.

Reports of Inspection of the Field Jurisdictions. Microfilm 1070.

Swanton, John R. Early History of the Creek Indians and Their Neighbors. Bulleting 74. Bureau of American Ethnology. Smithsonian Institution. Washington, D. C.: Government Printing Office, 1922.

- The Indian of the Southeastern United States. Bulletin 134. Bureau of American Ethnology. Smithsonian Institution. Washington, D. C.: Government Printing office, 1946.

- "Social Organization and Social Usages of the Indians of the Creek Confederacy." In Forty-second Annual Report of the United States Bureau of American Ethnology (1924-1925). Washington, D.C.: Government Printing Office, 1928.

United States office of Personnel Management. George w. Grayson File: st. Louis, Missouri.

War of the Rebellion: A Compilation of the official Records of the Union and Confederate Armies. Published under the Direction of the Secretary of War. Vol. 1 , series 4 ; vol. 13, series 1 ; part 1 , vol. 22, series 1 ; vol. 34 , series 1 ; part 1, vol. 41 , series 1. Washington, D. C.: Government Printing office, 1880-1901.

Works Progress Administration. Project s-149. "Indian-Pioneer Papers." Microfiche. Western History Collection. University of Oklahoma. Norman, Oklahoma.

31 stat., 861.

34 stat., 822.

38 stat., 599. 
Documents of Other Governments

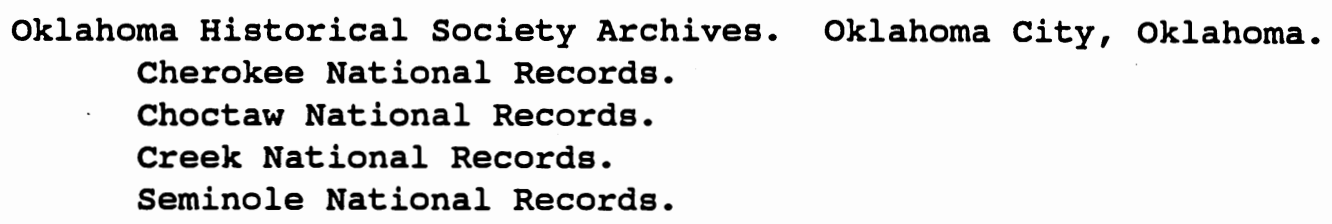

Gilcrease Institute of American History and Art. Tulsa, Oklahoma. Foreman, Grant, Collection.

Maxey, Samuel Bell, Collection.

Oklahoma Historical Society Archives. Oklahoma City, Oklahoma. Boyd, Robert S., Collection. Creek Indian Memorial Association Records. Foreman, Grant, Collection. opothlehola Collection. Robertson, Alice, Collection.

Special Collections. McFarlin Library. Tulsa University. Tulsa, Oklahoma.

Western History Collections. University of Oklahoma. Norman, Oklahoma. Cherokee Nation Papers. Phillips Collection. Division of Manuscripts Collections. Foreman, Stephen, Collection. Grayson Family Collection. Opothleyahola collection. Pitchlyn, Peter, Collection. Shumate, Enola, Collection.

Wilson, Woodrow, Papers. Microfilm. LIbrary of Congress. Washington, D. C.

Interviews

Carey, James E. Eufaula, Oklahoma. Interview, March 17, 1991.

Ewens, Mrs. Mildred Fuller. Eufaula, Oklahoma. Interview, October 910, 1989, March 12-13, 1990.

Follansbee, Mrs. Dorothy. Eufaula, Oklahoma. Interview, March 13, 1990, October 2, 1990. 
Manuscripts

Grayson, George Washington. Untitled manuscript. Property of Mrs. Mildred Fuller Ewens. Eufaula, Oklahoma.

Grayson, Georgeanna Stidham. Untitled manuscript. Property of Mrs. Mildred Fuller Ewens. Eufaula, Oklahoma.

Other Primary Material

Baird, พ. David, ed. A Creek Warrior for the Confederacy: The Autobiography of Chief G. W. Grayson. The Civilization of the American Indian Series, vol. 189. Norman: University of Oklahoma Press, 1988.

Duncan, D. W. C.; Grayson, G. W.; Cloud, Thomas; and Overton, B. F. "For the Advocate." Cherokee Advocate. Tahlequah, Cherokee Nation. January 5, 1881.

"Eufaula, Indian Territory, 1905." Sanborn Maps. Oklahoma Historical Society Archives, Oklahoma City, Oklahoma.

Grant, C. L., ed. Letters, Journals and Writings of Benjamin Hawkins, 2 vols. Savannah: The Beehive Press, 1980.

G[rayson], G. W. "Opothleyoholo." In Handbook of American Indians North of Mexico. 2 vols. Ed. Frederick Webb Hodge. New York: Pageant Books, 1959.

Grayson, G. W. Application to the United Daughters of the Confederacy for the Southern Cross of Honor, January 1, 1905. Property of Mrs. Mildred Fuller Ewens. Eufaula, Oklahoma.

- "A Talk on the White Settler Question." Indian Journal. Eufaula and Muskogee, Creek Nation. June 2, 1881.

Grayson, Wash, and Larney, James. "The Creek People." Indian Journal. Eufaula and Muskogee, Creek Nation. July 26, 1883.

Greenwood Cemetery. Inscriptions. Eufaula, Oklahoma.

"Sour Grapes." Muskogee Phoenix. Muskogee, Creek Nation. 1888.

Stidham, G. W. "What G. W. Stidham Thinks of the Vest Bill." Indian Journal. Eufaula and Muskogee, Creek Nation. January 8, 1880. 
Newspapers and Periodicals

The Arkansian. Fayetteville, Arkansas. 1859.

Atoka Independent. Atoka, Choctaw Nation. 1886-1887.

Chelsea Commercial. Chelsea, Indian Territory. 1905.

The Cherokee Advocate. Tahlequah, Cherokee Nation. 1878, 1880, 1888.

The Daily Oklahoman. Oklahoma City, Oklahoma. 1957.

Fort Smith Herald. Fort Smith, Arkansas. 1848.

Holdenville Times. Holdenville, Indian Territory. 1905.

The Indian Advocate. 1848.

The Indian Arrow. Vinita, Cherokee Nation. 1888-1889.

The Indian Chieftain. Vinita, Cherokee Nation. 1888-1889.

The Indian Missionary. Atoka, Choctaw Nation. 1888.

Muskogee Phoenix. Muskogee, Creek Nation, later Oklahoma. 1888-1915.

New State Tribune. Muskogee, Indian Territory. 1906.

New York Times. New York, New York. 1880.

The Okemah Independent. Okemah, Indian Territory. 1904.

The Okmulgee Daily News. Okmulgee, Oklahoma. 1920.

The Okmulgee Democrat. Okmulgee, Oklahoma. 1920.

St. Louis Globe Democrat. St. Louis, Missouri. 1880.

Sumner County Press. Sumner County, Kansas. 1880.

The Tahlequah Arrow. Tahlequah, Indian Territory. 1903.

Tulsa Daily World. Tulsa, Indian Territory. 1906.

The Vindicator. Atoka and New Boggy, Choctaw Nation. 1873-1875.

Indian Journal. Eufaula and Muskogee, Creek Nation; Eufaula, Oklahoma. 1877-1920. 
Secondary Sourceg

Books

Abel, Annie Heloise. The American Indian as Participant in the Civil War. Cleveland: Arthur H. Clarke Company, 1919.

- The American Indian as Slaveholder and Secessionist: An Omitted Chapter in the Diplomatic History of theSouthern Confederacy. Cleveland: Arthur H. Clarke Company, 1915.

Brown, Jennifer S. H.; and Jacqueline Louise Peterson. The New People: Being and Becoming Metis in North America. Winnipeg: University of Manitoba Press, 1985.

Debo, Angie. And Still the Waters Run: The Betrayal of the Five Civilized Tribes. Paperback edition. Norman: University of Oklahoma, 1989.

- The Road to Disappearance: A History of the Creek Indians. The Civilization of the American Indian Series. Norman: University of Oklahoma, 1941.

Edmunds, R. David. Tecumseh and the Quest for Indian Leadership. Boston: Little, Brown and Company, 1984.

Fischer, LeRoy H. The Battle of Honey Springs. Oklahoma City: Oklahoma Historical Society, 1988.

Foreman, Grant. Down the Texas Road: Historic Places along Hiqhway 69 through Oklahoma. Norman: University of Oklahoma, 1936.

- The Five Civilized Tribes: Cherokee, Chickasaw, Choctaw, Creek, Seminole. Norman: University of Oklahoma Press, 1934.

Garland, Hamlin. "The Final Council of the Creek Nation." In Hamlin Garland's Observations on the American Indian, 1895-1905. Ed. Lonnie E. Underhill and Daniel F. Littlefield, Jr. Tuscon: University of Arizona Press, 1976.

Gatschet, Albert A. A Migration Legend of the Creek Indians. Brinton's Library of Aboriginal American Literature, no. 4. Philadelphia: D G. Brinton, 1884 .

Gibson, Arrell Morgan. The American Indian: Prehistory to the Present. Norman: University of Oklahoma, 1980.

- The Chickasaws. Norman: University of Oklahoma Press, 1971. 
- "The Golden Years." In Oklahoma: A History of Five Centuries. 2nd ed. Norman: University of Oklahoma Press, 1981.

Grady, James T., ed. The state of Oklahoma: Its Men and Institutions. Oklahoma City: The Daily Oklahoman, 1908.

Green, Micael D. The Politics of Indian Removal: Creek Government and Society in Crisis. Lincoln: University of Nebraska Press, 1982.

Griffith, Benjamin W., Jr. McIntosh and Weatherford, Creek Indian Leaders. Tuscaloosa: University of Alabama Press, 1988.

Hastain, E. H. Township Plats of the Creek Nation. Muskogee: n.p., c. 1908.

Hoig, Stan. David L. Payne: The Oklahoma Boomer. Oklahoma City: Western Heritage Books, 1980.

- The Oklahoma Land Rush of 1889. Oklahoma City: Oklahoma Historical Society, 1984.

Relly, Lawrence C. "Cato Sells, 1913-1921." In The Commissioners of Indian Affairs, 1824-1977. Ed. Robert M. Kvasnicka and Herman J. Viola. Lincoln: University of Nebraska Press, 1979.

Kupperman, Karen Ordahl. Settling with the Indians: The Meeting of English and Indian Cultures in America, 1580-1640. Totowa, N.J.: Rowman and Littlefield, 1980.

Lambeth, David Michael. The World and Way of the Creek People. n.p., n.d.

Lemke, W. J. Early Colleges and Academies of Washington County, Arkansas. Bulletin Series, no. 6. Fayetteville, Ark.: Washington County Historical Society, 1954.

Littlefield, Daniel F. Africans and Creeks: From the Colonial Period to the Civil War. Contributions to Afro-American Studies, no. 47. Westport, Conn.: Greenwood Press, 1979.

Littlefield, Daniel F., and James W. Parins. A Bibliography of Native American Writers, 1772-1924. Native American Bibliography Series, no. 2. Metuchen, N. J.: The Scarecrow Press, 1981.

Marable, Mary Hays, and Boylan, Elaine. A Handbook of Oklahoma Writers. Norman: University of Oklahoma Press, 1939.

Martini, Don. Southeastern Indian Notebook: A BiographicalGenealogical Guide to the Five Civilized Tribes. Ripley, Miss.: Ripley Printing Company, 1986. 
Maxwell, Amos D. The Sequoyah Constitutional Convention. Boston: Meador Publishing Company, 1953.

Miller, Betty Tiger. "Moty Tiger." In History of Okmulgee County, oklahoma. Comp. and ed. Okmulgee County Historical Society and the Heritage Society of America. Tulsa: Heritage Enterprises, 1985 .

Morris, John W.; Goins, Charles R.; and MCReynolds, Edwin C. Historical Atlas of Oklahoma. rev. ed. Norman: University of Oklahoma, 1976

O'Beirne, H. F., and O'Beirne, E. S. The Indian Territory: Its Chiefs, Legislators, and Leading Men, 2 vols. St. Louis: C. B. Woodward, 1892 .

Opler, Morris Edward. "The Creek 'Town' and the Problem of Creek Indian Political Organization." In Human Problems in Technological Change: A Casebook, edited by Edward H. Spicer. New York: Russell Sage Foundation, 1952.

Posey, Mrs. Minnie H., ed. Poems of Alexander Lawrence Posey, Creek Indian Bard. rev. ed. N.p.: Okmulgee Cultural Foundation and Five Civilized Tribes Heritage Foundation, 1969.

Prucha, Francis Paul. American Indian Policy in Crisis: Christian Reformers and the Indian, 1865-1900. Norman: University of Oklahoma Press, 1976.

Rampp, Lary C., and Rampp, Donald L. The Civil War in Indian Territory. Austin: Presidial Press, 1975.

Rister, Carl Coke. Land Hunger. Norman: University of Oklahoma Press, 1942 .

Rohrs, Richard C. "Fort Gibson: Forgotten Glory." In Early Military Forts and Posts in Oklahoma, ed. Odie B. Faulk, Kenny A. Franks, and Paul J. Lambert. The Oklahoma Series, vol. 10. Oklahoma City: Oklahoma Historical Society, 1978.

Schoolcraft, Henry R. Information Respecting the History, Condition, and Prospects of the Indian Tribes of the United States: Collected and Prepared under the Bureau of Indian Affairg. Archives of Aboriginal Knowledge Series, vol. 1. Philadelphia: J. B. Lippincott, 1860.

Shirley, Glenn. Law West of Ft. Smith: A History of Frontier Justice in the Indian Territory, 1834-1896. New York: Henry Holt and Company, 1954.

Sturtevant, William C. "Commentary." In Eighteenth-Century Florida and Its Borderlands. Gainesville: University of Florida Press, 1975. 
Unrau, William E. Mixed-bloods and Tribal Dissolution: Charles Curtis and the Quest for Indian Identity. Lawrence: University of Kansas Press, 1989.

Wright, J. Leitch. Creeks and Seminoles: The Destruction and Regeneration of the Muscogulgee People. Lincoln: University of Nebraska Press, 1986.

\section{Articles}

Baird, W. David. "Are There 'Real' Indians in Oklahoma?" Chronicles of Oklahoma 68 (Spring 1990):4-23.

Coleman, R. B. "Indian Tribes in the Confederate Service." Confederate Veteran 23 (February 1915):73-74.

Confederate Veteran 9 (August 1901):357.

Foreman, Carolyn Thomas. "North Fork Town." Chronicles of Oklahoma 29 (Number 1, 1951): 79-111.

Harlow's Weekly 20 (February 25, 1921):6-7.

"Journal of the General Council of the Indian Territory." Chronicles of Oklahoma 3 (April 1925):32-44.

King, Jerlena. "Jackson Lewis of the Confederate Creek Regiment." Chronicles of Oklahoma 41 (Spring 1963):66-69.

Moore, William B., and Branson, Fred P. "Richard Clyde Allen." Chronicles of Oklahoma 36 (Winter, 1958-1959):489-491.

Morton, Ohland. "Reconstruction in the Creek Nation." Chronicles of Oklahoma 9 (June 1931):171-179.

"Okmulgee Constitution." Chronicles of Oklahoma 3 (September 1925):218228.

"Trouble Ahead." Indian Journal. Eufaula and Muskogee, Creek Nation. December 23, 1880 .

Unpublished Materials

Goodwin, Ralph William. "Pleasant Porter, Tribal Statesman." Master's thesis, University of Oklahoma, 1953. 
"Henryetta-Hugh Henry." Vertical File. Henryetta Public Library. Henryetta, Oklahoma.

Hoppe, Harold G. "In Re Grayson: A Critical View from a Native American Perspective." An unpublished paper. Property of Harold O. Hoppe. Wichita, Kansàs.

Hoppe, Harold 0 . "The Dissolution of a Nation: A Muscogee Retrospective." An unpublished paper. Property of Harold 0. Hoppe. Wichita, Kansas.

- "The Family of Robert Grierson and Sinoegee." Genealogical chart. Wichita, Kansas.

Peterson, Jacqueline Louise. "The People in Between: Indian-White Marriage and the Genesis of a Metis Society and Culture in the Great Lakes Region, 1680-1830." Ph.D. dissertation, University of Illinois at Chicago Circle, 1881.

"Retrospect of the Life and Character of Napoleon Bonaparte Moore." In The Muskogee Nation. n.p., n.d. Oklahoma Historical Society Archives, Oklahoma City, Oklahoma.

"Stidham Family." Vertical File. Oklahoma Historical Society Library. Oklahoma City, Oklahoma.

Vertical File. Jim Lucas Memorial Library. Checotah, Oklahoma. 


\author{
2 \\ VITA \\ Mary Jane Warde \\ Candidate for the Degree of \\ Doctor of Philosophy
}

Dissertation: GEORGE WASHINGTON GRAYSON AND THE CREEK NATION, 18431920

Major Field: History

Biographical:

Personal Data: Born in Fulton, Kentucky, June 29, 1944, the daughter of N. B. (Buster) and Frances Williams; married William D. Warde; two sons, Colin and Chris.

Education: Graduated from Martin High School, Martin, Tennessee, in June, 1962; received Bachelor of Arts degree in English and History from the University of Tennessee at Martin in June 1966; completed course work toward a Master of Arts degree at Florida State University in May, 1968; received the Master of Arts degree at Oklahoma State University in December 1981; completed requirements for the Doctor of Philosophy degree in May, 1991.

Professional Experience: Teaching Assistant, Department of History, Oklahoma State University, September 1979 to December 1981, from August 1983 to May 1985, from August 1986 to May 1989; Visiting Instructor, Department of Religion, History, and Philosophy, Phillips University, Enid, Oklahoma, August 1989 to May 1990; Lecturer, Department of History, Oklahoma State University, from August 1990 to May 1991.

Fellowships: Raymond Estep Fellowship, April 1988; Townsend Dissertation Fellowship, April 1989.

Professional Organizations: Organization of American Historians, Western History Association, Southern Historical Association, American Association of State and Local History, Oklahoma Historical Society, Payne County Historical Society. 